\title{
International Forest Policies in Indonesia: \\ International Influences, Power Changes and Domestic \\ Responses in REDD+, One Map and Forest Certification Politics
}

\author{
Dissertation \\ Submitted in partial fulfilment of requirements for the degree of \\ Doctor of Philosophy (PhD) \\ Faculty of Forest Sciences and Forest Ecology \\ Georg-August-Universität Göttingen
}

Submitted by

Agung Wibowo

Born in Sampit, Central Kalimantan, Indonesia 
1. Gutachterin/ 1. Gutachter: Prof. Dr. Max Krott (Name)

2. Gutachterin/ 2. Gutachter: Assoc. Prof. Dr. Dodik Ridho Nurrochmat (Name)

Tag der mündlichen Prüfung: 18 December 2015

(Datum) 
Chair of Forest and Nature Conservation Policy

Faculty of Forest Science and Forest Ecology

Georg-August-Universität Göttingen

GERMANY

The research presented in this book is funded by Indonesian Directorate General of Higher Education (DIKTI), German Academic Exchange Service (DAAD), and EVA-MAYR STIHL Foundation.

This research is conducted at the working group "International Forest Policy" at Chair Group of Forest and Nature Conservation Policy, Georg-August-Universität Göttingen, Germany.

Supervision: 1. Professor Dr. Max Krott

2. Lukas Giessen, Ph.D

International Forest Policy Country Studies:

1. Agung Wibowo (Indonesia)

2. Jacqueline Logmani (Germany)

3. Sarah L. Burns (Argentina)

4. Muhammad Alif Kaimuddin Sahide (Indonesia)

5. Md. Saifur Rahman (Bangladesh) 


\section{Dedicated to:}

My family and my country 


\section{Declaration of Authenticity}

I hereby declare that I am the sole author of this dissertation entitled: International Forest Policies in Indonesia: International Influences, Power Changes and Domestic Responses in REDD+, One Map and Forest Certification Politics. All references and data sources that were used in the dissertation have been appropriately acknowledged. I furthermore declare that this work has not been submitted elsewhere in any form as part of another dissertation procedure.

Göttingen, December 2015

Signed,

Agung Wibowo 
This space intentionally left blank 


\section{Acknowledgements}

I sincerely thank Prof. Dr. Max Krott for giving me opportunity to earn this PhD degree under his supervision. His clear guidance on theories used in this dissertation, on how to gather data effectively from bureaucracies and how to understand them, and on how to express ideas in a concise form has significantly improved my knowledge and skill in understanding how actors in the forestry field behave and struggle to reach their goals. He has always positively supported me to enhance research quality by expressing positive appreciation for my presentations, even when I felt they were not quite well developed. This treatment made me comfortable during my study time.

I also thank Assoc. Prof. Dr. Dodik Ridho Nurrochmat for reviewing my dissertation and being an examiner in my dissertation examination. He is my first mentor in Indonesian forest politics field and he provided me the way to meet Prof. Krott in Göttingen. I thank him for spending his valuable time to criticise and enrich my insight on theories I used, facts I presented, and my way of discussing research results in this dissertation.

My appreciation goes to Prof. Dr. Ralph Mitlöhner for being an examiner of my dissertation. His deep understanding on Indonesian forest politics and his critical "foreign view" helped me be able to view this dissertation from different angles in some cases.

I am truly in debt with Lukas Giessen, $\mathrm{PhD}$, my energetic daily supervisor who was always available to discuss my research, administrative, and personal problems. I am amazed that he always found solutions for those problems and made me feel better after leaving his room. His productive work has inspired me, and I am blessed and lucky to have met him.

My colleagues in the International Forest Policy Working Group contributed significantly to my scientific work. They are Jacqueline Logmany (Germany), Sarah Lilian Burns (Argentina), Muhammad Alif K. Sahide (Indonesia), and Md. Saifur Rahman (Bangladesh). Together we formulated research questions and hypotheses for our research group, and some of them co-authors in this cumulative dissertation. Other colleagues in the Chair Group of Forest and Nature Conservation Policy, e.g., Kenji Nagasaka (Japan), Budi Dharmawan (Indonesia) and Do Thi Huong (Viet Nam) also helped create an atmosphere conducive to scientific endeavour. I thank all of them.

This doctoral study would not have been possible without the support of and permission from directors at the university where I am based, namely the Head of the Forestry Department, the Dean of the Faculty of Agriculture, and the Rector of Palangka Raya University in Indonesia. The Indonesian Directorate General of Higher Education and the German Academic Exchange Service (DAAD) cooperated in an excellent way to award me an 8-semester PhD scholarship. I very much thank and acknowledge their support.

In addition, I reaped great benefits from institutions and persons in the course of my studies and daily life in Göttingen. These include the Embassy of the Republic of Indonesia in Berlin; Perhimpunan Pelajar Indonesia di Göttingen (Indonesia Student Association in Göttingen); Heike Zapf and Manfred Hellwig; secretaries at the Chair Group of Forest and Nature Conservation Policy; Jens Reimeyer, the IT-man at the Chair Group of Forest and Nature Conservation Policy; Dr. Eduardo Xavier Fargas, language editor of this dissertation; and influential Indonesians in Göttingen, namely Wak Tiny, Tante Evy, Bang Doel \& Teh Reni and Bang Gotham. 
Ultimately, I could not have finished this doctoral study without the endless support of my family in Indonesia. They include my lovely wife, daughter and son; my parents, and all my siblings in Sampit and Pelaihari. To them I dedicate this dissertation. 


\section{Summary}

The political contention that considers forests to be mere economic assets to achieve state welfare has slowly changed into a more conservative view since the Ninth World Forestry Congress in Mexico in 1985 rightly acknowledged that there has been severe tropical forest destruction and environmental deterioration around the globe. Several international agreements to address specific forestry issues have been established and new forms of forest governance have been formed, and an alliance of domestic and international actors have to implement these, mostly in forest-rich countries.. These attempts have sometimes met with difficulty, due to the domestic forest-related bureaucracies' own programmes and goals. Here, various interests in domestic politics compete for international support, resulting in the acceptance, rejection of, or changes to, those forest governances. Consequently, international forest governance may be adopted in a country in a form that is different from its original concept. To gain more insight into forest politics as carried out by bureaucracies, and its consequences for forest policy processes and forest resources, this dissertation examines the question of how forestrelevant bureaucracies respond to new international forest governance.

This framework contributes to a description of the bureaucratic processes involved in the implementation of selected international forest governances. For this purpose this framework will be structured as follows:

1. Theoretical framework on bureaucratic politics, domestic politics in response to international forest regimes, theory of power, and the concept of absolute and relative power gains;

2. Methodological framework for data collection and analysis of international forest issues relevant in Indonesia, the role of influential actors in specific cases, bureaucracies respond to forest policy introduced by other actors, and power dynamics of actors involved; and

3. Results, highlighting the selection of international forest governance forms by domestic bureaucracies, the effort bureaucracies make to restore their authority over forests, the international influence on forest politics, the forming of super bureaucracy and its suspension, and symbolic forest policy.

The origin of this framework consists of five articles, each of which addresses specific questions in selected study cases. The publications are listed below, together with a brief description.

Article 1: Wibowo, A., \& Giessen, L. (2015). Actor positions on primary and secondary international forest-related issues relevant in Indonesia. Journal of Sustainable Development, 8(3):10-27. This article identifies timber legality, climate change (including the REDD initiative) oil palm plantation and its environmental aspects, harmonisation of wood and forest certification schemes, land use change, forest and species conservation, and deforestation and decentralized forest governance as the seven most relevant forest issues in Indonesia.

Article 2: Wibowo, A., \& Giessen, L. (2015). Absolute and relative power gains among state agencies in forest-related land use politics: The Ministry of Forestry and its competitors in the REDD+ Programme and the One Map Policy in Indonesia. Land Use Policy, 49, 131-141. It describes how the two forest-related policies involving many state agencies do not work well since there is no strong leading agency responsible for them.

Article 3: Wibowo, A., Sahide, M.A.K, \& Giessen, L. (2015). From voluntary private to mandatory state governance in Indonesian forest certification: Reclaiming authority and legitimacy by bureaucracies. Article submitted to Global Environmental Change. This describes the strategy of the 
Ministry of Forestry of increasing its influence over stakeholders along the value chain of domestic timber business, by utilising its authority in Indonesia-EU FLEGT-VPA negotiation.

Article 4: Pratiwi, S., Wibowo, A., \& Giessen, L. (2015). Third-party certification of forest management in Indonesia: Analysing stakeholders' recognition and preferences. Journal Manajemen Hutan Tropika [Journal of Tropical Forest Management], 21(2), 65-75. This unveils certification schemes preferred by industries and the criteria they use in selecting such schemes.

Article 5: Wibowo, A., Pratiwi, S., \& Giessen, L. (2015). Comparing forest certification and timber legality systems in Indonesia: Complementary or competitive? Environmental, Development and Sustainability, under revision. This compares two international and one national forest certification scheme with the timber legality verification system in Indonesia that uses the Forest Certification Assessment Guide (FCAG), and concludes that those schemes are in competition and that each of them tries to delegitimise the others.

These five publications answer the central question of how forest-relevant bureaucracies respond to new international forest governance. To address this central question, four questions that are more specific are formulated, namely:

(i) What policy instruments are international forest governances trying to apply to domestic forest policy?;

(ii) Who are the important domestic and non-domestic actors involved in the policy processes concerning specific forest issues?;

(iii) How do the main forest-related bureaucracies respond to forest policy introduced by other bureaucracies?; and

(iv) What are political factors influence the acceptance of new forest-related policies?.

We used non-participant observations, expert interviews, and content analyses of policy documents in most of our works. Specifically, online survey was used to identify stakeholders' perception on forest certification schemes working in Indonesia and Forest Certification Assessment Guide (FCAG) to compare the standard of forest sustainability certification and timber legality verification. We applied theory of actor-centred power, theory of power, concept of absolute and relative power gains, and domestic response to foreign agenda in all publications.

The results show that, first, forest-related bureaucracies are more responsive to issues with high economic benefit, and pay less attention to those with low economic benefit. They are also more involved with topics that become issues of international concern, such as timber legality, climate change and REDD+, and oil palm plantation and its environmental aspects. Second, domestic bureaucracies in charge of economic tasks are more involved in the forestry business than those in charge of environmental tasks. In addition to the Ministry of Forestry, the Ministry of Trade and the Ministry of Industry are the two ministries most involved in domestic forest governance. Other state agencies that influence domestic forest policy are UKP4 (Presidential Delivery Unit for Development Monitoring and Oversight, Unit Kerja Presiden Bidang Pengawasan dan Pengendalian Pembangunan), REDD+ Agency, BAPPENAS (National Development Planning Agency, Badan Perencanaan Pembangunan Nasional), DNPI (National Council on Climate Change, Dewan Nasional Perubahan Iklim). Third, domestic bureaucracies form alliances with central power in the states (the president) to be involved in or/and to shape domestic forest policies, and to cooperate with international actors to gain public legitimacy for the way in which they run their programmes. Fourth, the three main cases examined in this dissertation, namely REDD+, one map policy and forest certification, are likely to be symbolic only. Symbolic policy is defined as sense of a non-policy, which formulates goals and instruments but is not assigned with clear responsibilities in terms of 
implementing agencies, sufficient staff, budget resources and necessary information. This conclusion is based on the fact that REDD+ policy, as well as timber legality verification, are based on weak legal constructions, have no single and strong leading agency responsible for ensuring continuity, and have only weak long-term agendas with no stand-alone budgets or discrete staff. Weak legal construction means that the policy can be changed, postponed or discontinued by other powerful actors, and having no leading agency means that there is an absence of an actor with the power to direct and implement the policy or of an authority that would penalize anyone acting against it. 
This space intentionally left blank 


\section{Table of Contents}

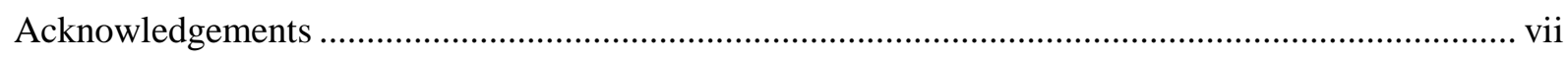

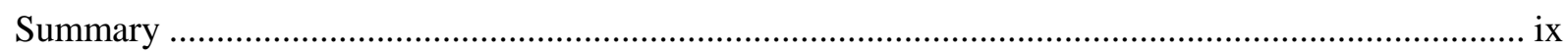

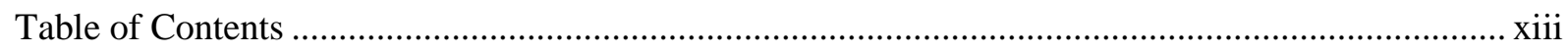

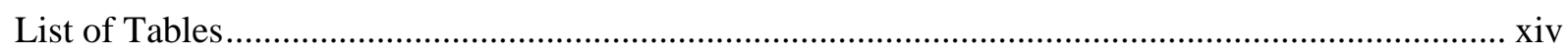

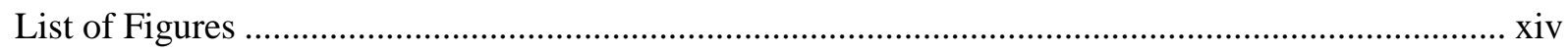

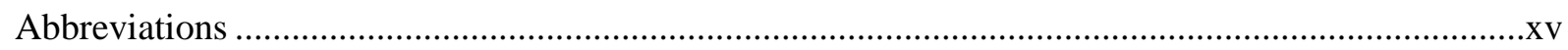

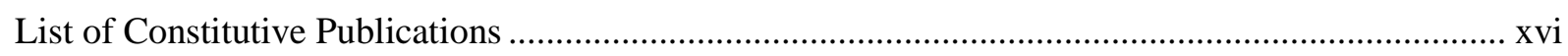

1. Introduction: Research Background and Guiding Questions ......................................................

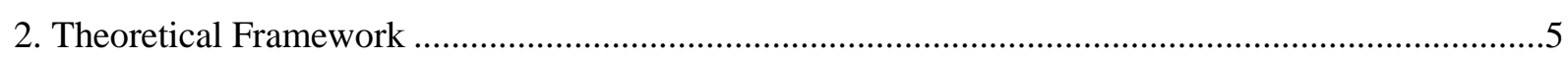

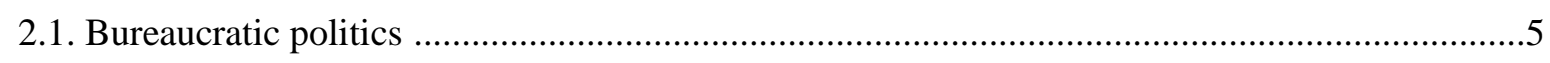

2.2. Domestic politics' response to international forest regimes and influential local actors..............5

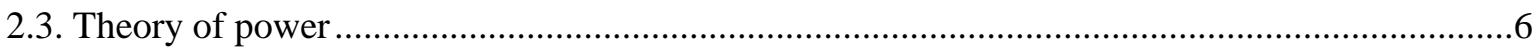

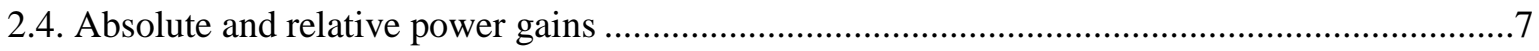

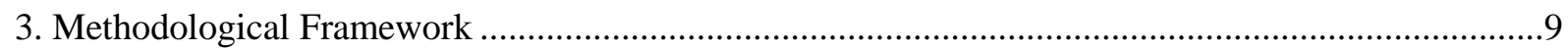

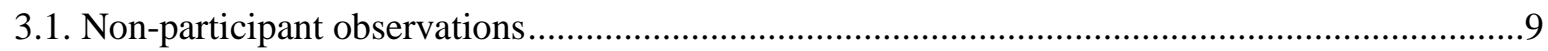

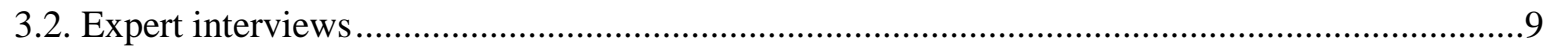

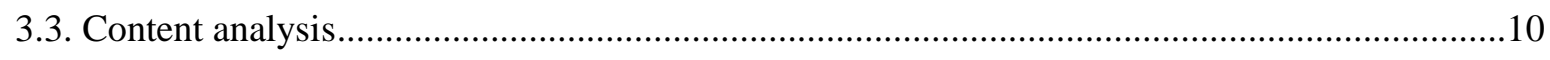

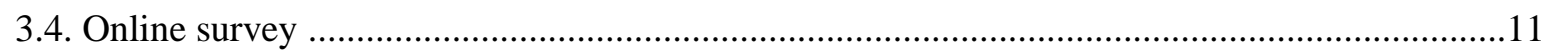

3.5. The Forest Certification Assessment Guide (FCAG) …...............................................................11

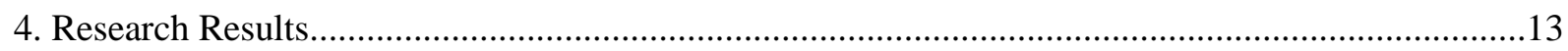

4.1. Economically viable and international forest issues are a greater concern for state

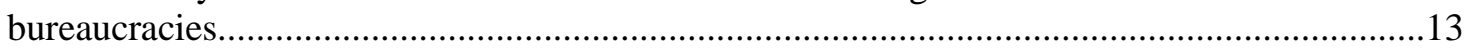

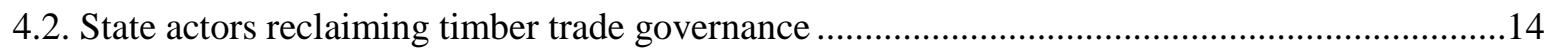

4.3. International influences changing domestic power structures and interactions ..........................16

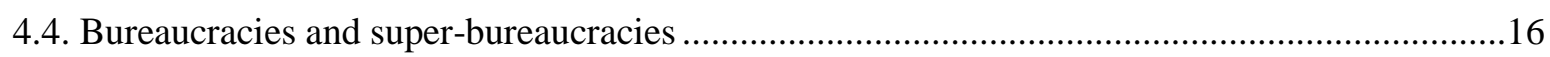

4.5. SVLK, REDD+ and One Map Policy as symbolic policies? ..................................................17

4.6. Contrasting forest certification with legality verification ........................................................18

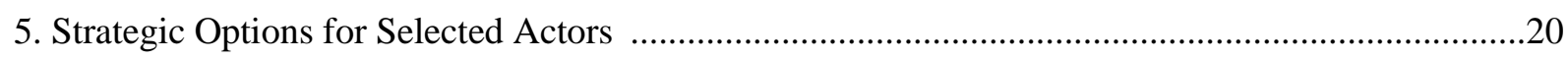

5.1. Strategic options for the Ministry of Environment and Forestry ...............................................20

5.2. Strategic options for Lembaga Ekolabel Indonesia (LEI) ........................................................20

6. References

Annex: Constitutive Publications

Curriculum Vitae 


\section{List of Tables}

Table 1 Overview of publications and their contributions to this study ...........................................

Table 2 Elements of power and their definitions, facts and examples ...........................................

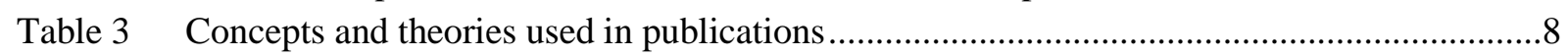

Table 4 Main forest related issues and major state agencies involved ...........................................13

Table $5 \quad$ Key feature of type of forest certification scheme in Indonesia........................................15

\section{List of Figures}

Figure 1 Phases in international forest governance and corresponding issues adopted by

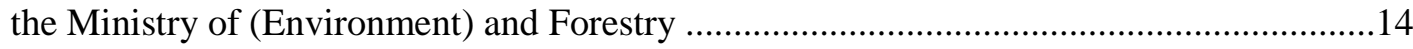

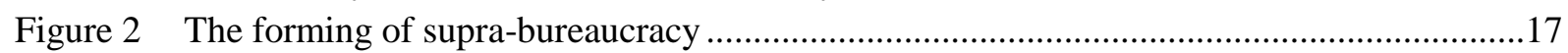

Figure 3 Competing forces in the forest certification business in Indonesia ...................................22 


\section{Abbreviations}

$\begin{array}{ll}\text { ACP } & \text { Actor-Centred Power } \\ \text { ASEAN } & \text { Association of Southeast Asian Nations } \\ \text { BAPPENAS } & \text { Badan Perencanaan Pembangunan Nasional (National Development Planning Agency) } \\ \text { CBD } & \text { Convention on Biological Diversity } \\ \text { CoC } & \text { Chain of Custody } \\ \text { DNPI } & \text { Dewan Nasional Perubahan Iklim (National Council on Climate Change) } \\ \text { EU } & \text { European Union } \\ \text { FAO } & \text { Food and Agriculture Organization } \\ \text { FCAG } & \text { Forest Certification Assessment Guide } \\ \text { FLEGT } & \text { Forest Law Enforcement, Governance and Trade } \\ \text { FSC } & \text { Forest Stewardship Council } \\ \text { ISO } & \text { International Organization for Standardization } \\ \text { ISPO } & \text { Indonesian Sustainable Palm Oil } \\ \text { ITTO } & \text { International Tropical Timber Organization } \\ \text { LEI } & \text { Lembaga Ekolabel Indonesia (Indonesian Ecolabel Institute) } \\ \text { Mo(E)F } & \text { Ministry of (Environment) and Forestry } \\ \text { NGO } & \text { Non-Governmental Organization } \\ \text { PEFC } & \text { Programme for the Endorsement of Forest Certification } \\ \text { REDD+ } & \text { Reducing Emissions from Deforestation and Forest Degradation (plus) } \\ \text { RSPO } & \text { Roundtable on Sustainable Palm Oil } \\ \text { SFM } & \text { Sustainable Forest Management } \\ \text { SVLK } & \text { Sistem Verifikasi Legalitas Kayu (Timber Legality Verification System) } \\ \text { UKP4 } & \text { Unit Kerja Presiden Bidang Pengawasan dan Pengendalian Pembangunan } \\ & \text { (Presidential Delivery Unit for Development Monitoring and Oversight) } \\ \text { UNECE } & \text { United Nations Economic Commission for Europe } \\ \text { UNFCCC } & \text { United Nations Framework Convention on Climate Change } \\ \text { VPA } & \text { Voluntary Partnership Agreements } \\ \text { WB } & \text { World Bank } \\ \text { WTO } & \text { World Trade Organization } \\ \text { WWF } & \text { World Wide Fund for Nature } \\ & \end{array}$




\section{List of Constitutive Publications}

1. Wibowo, A., \& Giessen, L. (2015). Actor positions on primary and secondary international forestrelated issues relevant in Indonesia. Journal of Sustainable Development, 8(3):10-27.

2. Wibowo, A., \& Giessen, L. (2015). Absolute and relative power gains among state agencies in forest-related land use politics: The Ministry of Forestry and its competitors in the REDD+ Programme and the One Map Policy in Indonesia. Land Use Policy, 49, 131-141.

3. Wibowo, A., Sahide, M.AK, \& Giessen, L. (2015). From voluntary private to mandatory state governance in Indonesian forest certification: Reclaiming authority and legitimacy by bureaucracies. Article submitted to Global Environmental Change.

4. Pratiwi, S., Wibowo, A., \& Giessen, L. (2015). Third-party certification of forest management in Indonesia: Analysing stakeholders' recognition and preferences. Jurnal Manajemen Hutan Tropika [Journal of Tropical Forest Management], 21(2), 65-75.

5. Wibowo, A., Pratiwi, S., \& Giessen, L. (2015). Comparing forest certification and timber legality systems in Indonesia: Complementary or competitive? Environmental, Development and Sustainability, under revision. 


\section{Introduction: Research Background and Guiding Questions}

The political contention that considers forests to be mere economic assets to achieve state welfare has slowly changed into a more conservative view since the Ninth World Forestry Congress in Mexico in 1985 rightly acknowledged that there has been severe tropical forest destruction and environmental deterioration around the globe. Since then, several international agreements to address specific forestry issues have been drafted and established as solid forms of forest governance (Humphreys, 2006). According to the Global Forest Expert Panel/GFEP (Glück et al., 2010), the core component of the international forest governance arrangements is "international multilateral intergovernmental treaties and agreements which directly address forests, either focusing on sustainable forest management or more specific goals, such as biodiversity conservation or climate change mitigation; and have achieved, or have the potential to achieve, significant effects on forests." The GFEP further identified eight policy instruments as core components of the international forest regime complex, namely (i) Non-legally binding instruments on all types of forests (NLBI), (ii) the International Tropical Timber Agreement (ITTA), (iii) forest certification schemes, (iv) world trade agreements (WTAs), (v) forest law enforcement, governance and trade (FLEGT), (vi) the Convention on Biological Diversity (CBD), (vii) the Convention on International Trade in Endangered Species of Wild Fauna and Flora (CITES), and (viii) the climate change regime (Glück et al., 2010).

International actors implemented those forms of international forest governance and their policy instruments in certain states. These included nation-state actors, intergovernmental organisations, treaty secretariats, multilateral financial institutions, regional and other multilateral organisations, nongovernmental organisations, and business and industry (Chasek et al., 2013), with the later addition of international bureaucracies and science networks (Biermann and Pattberg, 2012). However, the efforts of those actors to influence domestic forest policy faced many challenges. Lindstad and Solberg (2010) studied these challenges by determining the effect of international policy processes on forest protection in Norway using Underdal's approach (2002). This approach requires three points of reference as a basis from which to measure influence, namely, the initial situation, a condition without a regime; the actual situation, an endpoint at which a regime performs within a certain time; and the agreement's objective, the point where a regime's performance is intended to be. They then calculated an effectiveness index using a formula proposed by the Oslo-Potsdam Solution (Helm and Sprinz, 2000), and found that a numerical value such as the effectiveness index increased confusion instead of providing enlightenment. In addition, this index could not separate the many influences resulting from national and international factors and, in addition, it could not provide clear figures for the cause-effect relationship and was only able to reflect a limited number of regimes in a regime complex.

Bernstein and Cashore (2012) argue that forest regime effectiveness is too complicated to measure, since regimes have multiple channels of influence and represent a complex (not a one-way) interaction between global and domestic politics. They then propose a shift in focus of study, from effectiveness to influence, and they develop four pathways of influence, specifically: international rules; international norms and discourse; markets; and direct access to domestic policy-making processes (Bernstein and Cashore, 2000, 2012). Wilson (2003) used the framework of four pathways later on to track transnational influence on the conservation of boreal ecosystems in Canada, and he found that each of them "works" in various degrees and reckoned that it seems to be used continuously. Since then there has been abundant research studying the influence of international forest-related regimes in specific 
countries, for example: the influence of international actors in changing Brazil's position on climate change (Kasa, 2013), how the business sector led to the institutionalisation of unsustainable timber practices in Russia (Ulybina and Fennell, 2013), how multilevel governance motivated and facilitated knowledge transfer and learning in climate change negotiations (Rietig, 2014), how third-party organisations influence timber regulation in Sweden (Johansson and Keskitalo, 2014), the relevance of global and regional land use regimes in Indonesia (Sahide et al., 2015a), and the mapping of international actors' positions in domestic forest-related issues in Bangladesh (Rahman and Giessen, 2014), Argentina (Burns and Giessen, 2014) and Indonesia (Wibowo and Giessen, 2015a).

Although one may know a specific path has been used in influencing domestic forest policy, the ways in which international forest actors and governance work at a domestic level are unclear, as are the ways in which local bureaucracies respond to ideas until they are finally implemented, rejected or changed. In addition, an international forest policy instrument may be in intense competition with others. At this point, it is important to study in depth how local bureaucracies interact and form coalitions in response to international forest governance and its policy instruments, and what the results of this response are.

This dissertation seeks to explain this by using the example of Indonesia. Indonesia was selected as a country for study for three reasons. First, as a developing country, it is very influenced by international actors in terms of gaining financial support from foreign countries and international funding resources. Second, deforestation resulting from the development of forest plantations for pulp, paper and palm oil generates market resistance to those products, which influences the government's other decisions pertaining to forests. Third, the forestry sector is facing heavy pressure from agricultural, mining and plantation sectors, as local governments seek sources of income to fund their local development by converting forests to other more marketable sectors, resulting in intense competition among new and old state agencies. The REED+, One Map, and forest certification politics are selected as case studies for further analysis since the three cases have been identified as the most relevant forest issues in Indonesia (Wibowo and Giessen, 2015a). For this examination, this dissertation proposes its guiding question to be:

\section{How do forest-relevant bureaucracies respond to new international forest governance?}

In order to answer this main question, we suggest four other specific questions, namely:

- What policy instruments of international forest governance are trying to influence forest domestic policy?

- Who are the important domestic, non-domestic, and international actors involved in the policy process that pertain to specific forest issues?

- How do the main forest-related bureaucracies respond to forest policy introduced by other actors?

- What are political factors that influence the success of new forest-related policy?

These specific questions will be answered in a cumulative $\mathrm{PhD}$ dissertation consisting of 10 peerreviewed publications. The brief descriptions of each work and contributions of the author of this dissertation (indicated in bold here and in the other articles in the list) and other individual authors to the constitutive publications (Article 1-5) are detailed below.

Article 1: Wibowo, A., \& Giessen, L. (2015). Actor positions on primary and secondary international forest-related issues relevant in Indonesia. Journal of Sustainable Development, 8(3):10-27. This article identifies timber legality, climate change (including the REDD initiative) oil palm plantation and its environmental aspects, harmonisation of wood and forest certification schemes, land use change, forest and species conservation, and deforestation and decentralized forest governance as the 
seven most relevant forest issues in Indonesia. Giessen developed theory and hypotheses of the study, and developed the methodology and methods. Wibowo adapted and applied the theory and hypotheses to the case, adapted and applied the methodology to the case, and produced case findings regarding international forest policies in Indonesia.

Article 2: Wibowo, A., \& Giessen, L. (2015). Absolute and relative power gains among state agencies in forest-related land use politics: The Ministry of Forestry and its competitors in the REDD+ Programme and the One Map Policy in Indonesia. Land Use Policy, 49, 131-141. This article shows that the two forest-related policies involving many state agencies do not work well because there is no strong leading agency responsible for them. Giessen developed theory and hypotheses of the study, and developed the methodology and methods. Wibowo adapted and applied the theory and hypotheses to the case, adapted and applied the methodology to the case, and produced case findings regarding international forest policies in Indonesia.

Article 3: Wibowo, A., Sahide, M.AK, \& Giessen, L. (2015). From voluntary private to mandatory state governance in Indonesian forest certification: Reclaiming authority and legitimacy by bureaucracies. Article submitted to Global Environmental Change. This explains the strategy of the Ministry of Forestry in increasing its influence over stakeholders along the value chain of domestic timber business by utilising its authority in the Indonesia-EU FLEGT-VPA negotiation. Giessen developed theory and hypotheses of the study, and developed the methodology and methods. Wibowo adapted and applied the theory and hypotheses to the case, adapted and applied the methodology to the case, and produced case findings regarding international forest policies in Indonesia. Sahide applied methodology to the case and produced case findings on Indonesian bureaucracies using international regimes.

Article 4: Pratiwi, S., Wibowo, A., \& Giessen, L. (2015). Third-party certification of forest management in Indonesia: Analysing stakeholders' recognition and preferences. Jurnal Manajemen Hutan Tropika [Journal of Tropical Forest Management], 21(2), 65-75. This describes the certification schemes preferred by industries and the criteria they use in selecting such schemes. The author contributed in the formulation of research questions, organising the research method, and discussing the results. Giessen developed theory and hypotheses of the study. Giessen and Wibowo developed the methodology and methods. Wibowo and Pratiwi adapted and applied the theory and hypotheses to the case, adapted and applied the methodology to the case, and produced case findings regarding international forest policies in Indonesia.

Article 5: Wibowo, A., Pratiwi, S., \& Giessen, L. (2015). Comparing forest certification and timber legality systems in Indonesia: Complementary or competitive? Environmental, Development and Sustainability, under revision. This compares two international and one national forest certification scheme with the timber legality verification systems in Indonesia, using the Forest Certification Assessment Guide (FCAG), and concludes that each of those schemes are in competition and tries to delegitimise the others. The author contributed data analysis and the formulation of the conclusion. Giessen developed theory and hypotheses of the study. Giessen and Wibowo developed the methodology and methods. Wibowo and Pratiwi adapted and applied the theory and hypotheses to the case, adapted and applied the methodology to the case, and produced case findings regarding international forest policies in Indonesia.

The main contributions of each work to this study are given in Table 1. 
Table 1: Overview of publications and their contributions to this study

\begin{tabular}{|c|c|c|c|c|}
\hline No & Publication & $\begin{array}{c}\text { Theory } \\
\text { development }\end{array}$ & $\begin{array}{c}\text { Development } \\
\text { of } \\
\text { methodology }\end{array}$ & $\begin{array}{l}\text { Novel } \\
\text { results }\end{array}$ \\
\hline 1 & $\begin{array}{l}\text { Wibowo, A., \& Giessen, L. (2015). Actor Positions on } \\
\text { primary and secondary international forest-related issues } \\
\text { relevant in Indonesia. Journal of Sustainable } \\
\text { Development, } 8(3): 10-27 \text {. }\end{array}$ & & 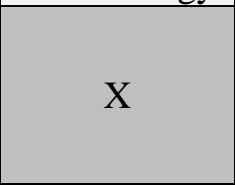 & $X$ \\
\hline 2 & $\begin{array}{l}\text { Wibowo, A., \& Giessen, L. (2015). Absolute and } \\
\text { relative power gains among state agencies in forest- } \\
\text { related land use politics: The Ministry of Forestry and its } \\
\text { competitors in the REDD+ Programme and the One Map } \\
\text { Policy in Indonesia. Land Use Policy, 49, 131-141. }\end{array}$ & $X$ & & $\mathrm{X}$ \\
\hline 3 & $\begin{array}{l}\text { Wibowo, A., Sahide, M.A.K, \& Giessen, L. (2015). } \\
\text { From voluntary private to mandatory state governance in } \\
\text { Indonesian forest certification: Reclaiming authority and } \\
\text { legitimacy by bureaucracies. Article submitted to Global } \\
\text { Environmental Change. }\end{array}$ & $X$ & & $X$ \\
\hline 4 & $\begin{array}{l}\text { Pratiwi, S., Wibowo, A., \& Giessen, L. (2015). Third- } \\
\text { party certification of forest management in Indonesia: } \\
\text { Analysing stakeholders' recognition and preferences. } \\
\text { Jurnal Manajemen Hutan Tropika [Journal of Tropical } \\
\text { Forest Management], 21(2), 65-75. }\end{array}$ & & & $X$ \\
\hline 5 & $\begin{array}{l}\text { Wibowo, A., Pratiwi, S., \& Giessen, L. (2015). } \\
\text { Comparing forest certification and timber legality } \\
\text { systems in Indonesia: Complementary or competitive? } \\
\text { Environmental, Development and Sustainability, under } \\
\text { revision. }\end{array}$ & & & X \\
\hline
\end{tabular}

We selected findings from the works listed above to answer the specific research questions posed in advance, and structured them according to following sections:

- Theoretical framework on bureaucratic politics, domestic politics in response to international forest regimes, theory of power, and the concept of absolute and relative power gain;

- Methodological framework for data collection and analysis of international forest issues relevant in Indonesia, the role of influential actors in specific cases, bureaucracies respond to forest policy introduced by other actors, and power dynamics of actors involved;

- Results, highlighting the selection of international forest governance forms by domestic bureaucracies, the effort bureaucracies make to restore their authority over forests, the international influence on forest politics, the forming of super bureaucracy and its suspension, and symbolic forest policy; and

- Strategic options for selected actors. Based on scientific findings, this last chapter offers strategic policy suggestions for selected policy actors. Two major national agencies affected by international forest regimes, the Ministry of Environment and Forestry and Lembaga Ekolabel Indonesia, serve as examples for the transfer of findings to political practice.

A detailed picture of these forest politics assignments could be used to explain the cause of forest policy failures in the past or estimate the degree of success of future forest policy processes and/or implementation from the perspective of bureaucratic politics. Therefore it could be useful information for other countries. The studies in this dissertation contribute an explanation of how international actors choose and forge alliances to implement their forest-related policy agendas in Indonesia. 


\section{Theoretical Framework}

This study drew on the theory of international influences and bureaucratic politics. It analysed domestic consequences at national level, focusing on the power structures among the main actors, and not on policy content as such. Below is a brief description for each of the concepts and theories used in this dissertation, and a summary of their uses in publications, presented in Table 3.

\subsection{Bureaucratic politics}

Bureaucratic politics theory is used to accommodate a broader palette of actors that may be influencing forest policies at national level. According to Bauer et al. (2012: 28), bureaucracies are "agencies that have been created by governments or other public actors with some degree or permanence and coherence and beyond formal direct control of single nation governments and that act in the international arena to pursue a policy." Bureaucracies are different from organisations, which are institutional arrangements built upon normative frameworks, members, and bureaucracies as administrative core institutions; and institutions, which are merely sets of principles and norms (Bauer et al., 2012: 28-29).

Bureaucracies have a formal goal in serving the public interest and an informal goal in surviving and in expanding organisational interests, like maximising power, budget and staff; where organisational interests are prioritised if formal and informal goals cannot be achieved simultaneously (Niskanen, 1974; Krott et al., 1990; Peters, 2002; Allison and Zelikow, 1999). Although this seems to be logical, the behaviour of a bureaucracy as noted above is not homogenous, since it depends on the capability of each bureaucrat to gain personal benefit (Blais and Dion, 1990). As an initial assumption, this study accepts that Niskanen's view is widely applicable. To pursue those dual goals, bureaucrats could act as political institutions and administrative bodies (Krott, 2005). As political institutions they are equipped with legitimacy, public mandate, financial resources and competent staffs; and as administrative bodies, bureaucracies have expertise and information, administrative ideology, decision-making power, alliances, permanent positions, and a disregard for politics.

Giessen et al. (2014) show that utilitarian (economic) bureaucracies compete with specialised bureaucracies in international forest and forest-environmental policy negotiations, which suggests that the economic interests of the state figure strongly in forest-environmental negotiations. Based on this propensity, one can argue that competition for budget allows ministries in charge of economic tasks (e.g., ministry of economics) to have more power in deciding which foreign ideas should be adopted. In contrast, as environmental issues are discussed with increasing intensity in the arena of international negotiations, bureaucracies with environmental duties (e.g., ministry of the environment and ministry of economy) also have more power to justify their programmes in order to succeed within "the global agenda". Based on this thought, this dissertation theorises that bureaucracies compete to secure external support due to internationalisation of forest issues, which can also be used to increase legitimacy, power source, and bargaining positions for strategic tasks at a domestic level.

\subsection{Domestic politics' response to international forest regimes and influential local actors}

In response to a policy agenda introduced by foreign actors, domestic bureaucracies have the options to reject, fully accept, partially accept, or change such an agenda. The decision depends greatly on the 
degree to which they receive benefits like increased staff, working plans, and formal tasks (Peters, 2002). In general, policy process carried out by bureaucracies in response to new policy agendas will go through five stages of a policy cycle (Howlett and Ramesh, 1995:13), namely, agenda-setting, policy formulation, decision-making, policy implementation and policy evaluation. Prior to reaching the decision-making stage, any idea could be changed if it does not match the interests of the bureaucracies.

Major policy changes in a country may occur if external political, economic and social conditions change significantly (Giessen, 2011), through processes involving, among others, policy learning; ideas and discourses; policy entrepreneurs and experts; policy networks, subsystems and their bureaucracies; external shocks and crises; internationalisation trends; veto players; ruling political parties; and institutional change (Giessen et al., 2014). These are the starting points for changes that allow bureaucracies to contact international actors, negotiate their interests, set up coalitions, arrange mutual agendas, and finally, gain power. Power and information become important factors used by bureaucracies to achieve conflict resolution between actors in forest utilisation conflicts (Krott, 2005).

International forest policies intended for implementation on the ground should involve provincial and district governments, non-governmental organisations, local people, and forest-related associations in the policy-making process, as these are influential stakeholders in forest affairs (Nurrochmat et al., 2015a). In addition, the success of recent forest policy developments demands the participation of local people, respect for indigenous people rights, and openness toward public input (Bernstein and Cashore, 2012), which are closely linked with those non-state actors. That is why, despite the fact that this dissertation focusses on the bureaucratic politics surrounding forest resources, the above actors are always taken into account in the analyses to some extent.

\subsection{Theory of power}

As mentioned earlier, bureaucracies can only run any policy if they are equipped with the "fuel" which political literature calls power. After analysing various power theories by Weber (1972), Giddens (1984), Arts and van Tatenhove (2004), Lukes (1974), Dahl (1957) and Simon (1981); Krott et al. (2014) presented the actor-centred power (ACP) approach as a new analytical framework for assessing bureaucratic obstacles faced by forestry programmes. Krott et al. (2014) define power as a social relationship in which actor $A$ has the ability to alter the behaviour of actor B without recognising $B$ 's will. In other words, power could be the ability to shape a programme according to one's owns interests, even against resistance from other actors. According to Krott et al. (2014), power consists of three elements, and it can be ascribed to one actor or it can be distributed among several, equal actors. The first element of power, coercion, is defined as altering the behaviour of the subordinate by force. In a social relationship, coercive power is associated mainly with bureaucracy, where the people provide the bureaucracy with a mandate through law for it to implement any agreed rules and to reinforce such rules by applying sanctions to those who disobey them. The second element is (dis)incentives, which is defined as advantages or disadvantages introduced to alter the behaviour of the subordinate. Authorities could direct others' behaviour by introducing a disadvantage, e.g., the revocation of permits for forest concessionaires, for those who fail to perform harvesting operations in an ecologically sound manner. Advantages could also change subordinates' behaviour because all actors naturally desire to maximize their benefits. The last element of power is dominant information, which means unverifiable information. Information can be classified as pure information, which can be easily verified by recipients, and selected information, which recipients can verify only with difficulty, or not at all, due to a lack of capacity, lack of will, or distrust in the information provider. 
Dominant information becomes an element of power because actors without valid information cannot easily make appropriate decisions. In this context, dominant information includes any information that can be provided only by a state agency and that is needed by other stakeholders. In some cases, the absence of such information for the public due to 'unwillingness to share' or 'unavailability to share' could be used to increase the bargaining position of the agency responsible for it. Table 2 gives an overview of these three power elements.

Table 2: Elements of power and their definitions, facts and examples

\begin{tabular}{|l|l|l|l|}
\hline Element & Definition & Observable facts & Example \\
\hline Coercion & $\begin{array}{l}\text { Altering behaviour } \\
\text { by force }\end{array}$ & $\begin{array}{l}\text { Revocation of rights or physical } \\
\text { action, threat of either }\end{array}$ & Removal of forest user rights \\
\hline $\begin{array}{l}\text { (Dis-) } \\
\text { incentives }\end{array}$ & $\begin{array}{l}\text { Altering behaviour } \\
\text { via (dis-)advantages }\end{array}$ & $\begin{array}{l}\text { Providing of, or threatening with } \\
\text { the removal of sources of } \\
\text { material and immaterial benefit }\end{array}$ & Financial support \\
\hline $\begin{array}{l}\text { Dominant } \\
\text { information }\end{array}$ & $\begin{array}{l}\text { Altering behaviour } \\
\text { by means of } \\
\text { unverified } \\
\text { information }\end{array}$ & $\begin{array}{l}\text { Providing of, or threatening with } \\
\text { removal of, source of unverified } \\
\text { information }\end{array}$ & $\begin{array}{l}\text { Exclusive data from the } \\
\text { Ministry }\end{array}$ \\
\hline
\end{tabular}

Source: Krott et al. (2014)

This study uses the ACP approach rather than the three dimensions of power by Lukes (2005), which is widely acknowledged as the main literature on the power concept (McCabe, 2013), because the ACP approach focusses on power as property, namely, the power to do something, regardless of whether this power is used (see Wibowo and Giessen, 2015b) for substantive discussion on both approaches). On the other hand, Lukes' three dimensions of power and previous works in which he criticized, e.g., Dahl (1957) and Bachrach and Baratz (1962), are focused on power as domination, widely known as power over (Haugaard, 2012), which may be identified from observable (overt and covert) and latent conflicts (Lukes, 2005: 29). In brief, Krott et al. (2014) assess "in terms of what" an actor has power, while Lukes (2005) assesses "over whom" an actor has power.

\subsection{Absolute and relative power gains}

The concept of absolute and relative power gains is used specifically in Article 2 (Wibowo and Giessen, 2015b), when the author analyses the power dynamics of the Ministry of Environment and Forestry and other bureaucracies in Indonesian REDD+ and One Map politics. This concept allows the author to quantify the power gained by each bureaucracy within a period of time and helps to decide who the real winner is in either forest policy process. Prabowo et al. (2015) acknowledge that simultaneous use of absolute and relative power gains concept and ACP approach by Wibowo and Giessen (2015b) has been enhancing the application of ACP approach.

In short, this concept enables the user to decide the real winner among two or more actors by comparing the amount of absolute/ultimate gain it obtains from its initial capability. The ratio of both figures is called relative gain (Halas, 2008). The actor with the higher percentage of relative gain is seen as the winner, compared to other actors with lower percentages of relative gain. There are three conditions under which a player can be considered the winner. First, when it has lower capabilities but obtains the same amount of absolute gain as that obtained by others. Second, when it has capabilities similar to those of to others but obtains more absolute gain. Lastly, when it has a higher capabilities and obtains more relative gain. An example of a winner would be a younger brother who receives as 
much money as his older brother from their parents, though he requires less to cover his needs than his older brother does. In the study, initial capability is a power source held by any actor, such as budget allocation, number of staff, strategic tasks, and exclusive information, whereas absolute gain refers to strategic tasks. The selection of strategic tasks as single indicator of absolute gain is based on the fact that every task should be equipped with sufficient power elements.

Table 3: Concepts and theories used in publications

\begin{tabular}{|c|c|c|c|c|}
\hline $\begin{array}{c}\text { Identity of } \\
\text { publication }\end{array}$ & $\begin{array}{c}\text { Bureaucratic } \\
\text { politics }\end{array}$ & $\begin{array}{c}\text { Local actors' } \\
\text { response }\end{array}$ & Theory of power & $\begin{array}{c}\text { Absolute and } \\
\text { relative power gains }\end{array}$ \\
\hline Article 1 & $\mathrm{X}$ & $\mathrm{X}$ & & \\
\hline Article 2 & $\mathrm{X}$ & $\mathrm{X}$ & $\mathrm{X}$ & $\mathrm{X}$ \\
\hline Article 3 & $\mathrm{X}$ & $\mathrm{X}$ & $\mathrm{X}$ & \\
\hline Article 4 & $\mathrm{X}$ & $\mathrm{X}$ & $\mathrm{X}$ & \\
\hline Article 5 & $\mathrm{X}$ & $\mathrm{X}$ & $\mathrm{X}$ & \\
\hline
\end{tabular}




\section{Methodological Framework}

All ten articles in this dissertation utilise well-established methods in data collection, namely observation, interviews, and document analyses. Specifically, those methods were used together with online survey to identify stakeholders' perception on forest certification schemes working in Indonesia (Article 4) and Forest Certification Assessment Guide (FCAG) to compare the standard of forest sustainability certification and timber legality verification (Article 5). Below are brief descriptions of the methods used in this dissertation.

\subsection{Non-participant observations}

According to Fenno (1986), observation is at the heart of political analysis since it shows the real behaviour of observed object in a certain period of time; hence what it demonstrates can be seen as the truth. Patton (2005) points out that observation, together with interview and content analysis, are useful and credible methods in qualitative research.

The author acted as a non-participant observer to record opinions, interests, and alliances made by the actors in several national and international forestry meetings between June and September 2013 in Bogor and Jakarta. The meetings included the National Conference on the Future of Production Forest Management (4 September 2013), the National Seminar on Indonesian Palm Oil (2 July 2013), the National Workshop on the Strategic Steps Post-Constitutional Court Ruling No.35/PUU-X/2012 (22 August 2013), the Indonesian Roundtable on Greening the National Development Plan (21 June 2013), National Workshop on the Forestry Law: Constitutional Court Ruling No.35/PUU-X/2012 (2930 August 2013), Workshop on Community-Based Forest Management (25 July 2013), and several meetings of NGOs concerning forest resource governance.

In each occasion the author noted the main messages delivered by the governments, international organisations, academics, NGOs, indigenous people, the business sector and other participants, and considered them to be the official position of the speaker on a particular issue. During coffee break, the author interacted with the participants, gathered their "less official statements" and handled them as primary data.

The challenge in collecting data through observation was that the actors involved in many meetings were more less the same, and therefore they slowly became aware of the presence of an outsider in their circle and became more distant in their conversations with the author. On the other hand, the author was aware that "the speakers" in Indonesia's forest governance are limited to persons in the capital, with very narrow involvement of the stakeholders from the provincial and district levels. The decision-making processes on regulations or recommendations generated from the meetings produced even by fewer people.

\subsection{Expert interviews}

Expert interviews are the second method used to gather data from the interviewees who had already been contacted before. The author classified as "experts" those who had at least five years of experience or held a PhD degree in a specific area of Indonesian forest governance. Harrison (2013) has suggested that information gathered from interviews should be categorised as raw data and that it 
should be checked against other sources. In this research, the author conducted semi-structured interviews, i.e., a conversation between interviewer and interviewee on specific predetermined topics, but one where participants are free to change the issues if they feel this is important (Longhurst, 2003).

The author uses interviews to identify the main actors and their positions on specific forest issues. Actors' positions and their prospective coalitions were gleaned from Faggi et al. (2014), Lozano (2013) and Tuppura et al. (2015). In analysing actors' positions we assumed that every actor behaved rationally, meaning that actors tried to maximize their own benefit rather than to promote a general goal, like maintaining environmental sustainability and equality. To contest norm- and interest-driven is acceptable (see: Van Schaik and Schunz, 2012; Gulbrandsen, 2003), since each actor (which can be an individual, organisation or state) has its own interests, adding to their effort to find common aspirations.

The main challenge in identifying the positions of actors (individuals who represent organisations or entities) is that they are present in many field of discussion about forestry, such as the preservation of local rights, timber legality, the REDD+ Programme, and palm oil plantation. One person could be a member of more than one organisation; hence the information about new forest policy circulates only within a limited number of people. Furthermore, the author found it difficult to separate between personal and organisational views within the interviewees' statements, therefore the author explicitly avoided the inclusion of these statements in the text.

\subsection{Content analysis}

Content analysis is a widely used qualitative research technique to interpret meaning from the content of text data (Hsieh and Shannon, 2005). In this book content analysis was used to analyze policy documents issued by the governments, stakeholders' opinion related to international forest issues in public media, stakeholders' position papers, and standards and systems established by relevant sources. We scrutinized total of 17 official documents issued by President and Government of Indonesia, 2 ministries and three other national bureaucracies in order to identify the power dynamics of bureaucracies in REDD+ and one map policies (Wibowo and Giessen, 2015b). As many as 19, 14, 24, and 3 standard, procedure and regulation of certification developed by FSC, PEFC, LEI and the Ministry of Environment and Forestry, respectively, were compared and assessed against FCAG framework (Wibowo et al., 2015b). In Nurrochmat et al. (2015b) we analyzed legal and sustainable timber regulations from ten ASEAN member states and seek options for beneficial timber trading inside ASEAN. Those documents were categorized and framed under corresponding theories in each article.

Specifically we used content analysis with some extend over public and professional media to identify international forest issues in Indonesia (Wibowo and Giessen, 2015a). For this we undertook two steps. First, we chose two national newspapers in the Indonesian language, the Media Indonesia and Kompas, and a national newspaper in English, namely The Jakarta Post. The combination of keywords hutan ("forest"), kayu ("wood"), internasional ("international") and global were inserted in each newspaper's search engine to elicit a first set of 200 relevant articles in order to identify relevant international issues within Indonesian public deliberation. Whether an article was considered to be relevant depended on the connection of its content with international forest-related issues in Indonesia. Second, based on identified keywords in the first step, the Google search engine was employed to find more relevant and concrete articles and comments. Only articles from public mass media were considered in order to map the public deliberation on a given issue. To explore deeper deliberations and to gather other relevant issues, the authors collected data from professional journals in the fields of 
forestry, agriculture and conservation (i.e. Majalah Kehutanan Indonesia, Tabloid Agro Indonesia and Mongabai), and any publications from international organisations related to the Indonesian forest sector. Selected issues may overlap in part in their categorisation due to differences in context or focus of deliberation. From the public and expert data sources, the authors elicited and interpreted the main actors' positions on the issues if applicable. The absence of any relevant news in the public media was taken as an indication that the issue was not important for the public or that it had not become a public concern. These steps were fully Internet-based, which has numerous limitations, such as lack of a central index, lack of quality control, the fact that not all information is complete, or that not all information is covered by the media (Dawson, 2003). However, the author did interview experts to get a balance of information on the issues.

\subsection{Online survey}

Online survey was used to identify stakeholders' perception on forest certification schemes and timber legality verification in Indonesia and their contribution to enhance forest and timber governance (Article 4/Pratiwi et al., 2015). The respondents were categorised into main respondents, which consisted of those from logging companies (LC), from the wood processing industry (WPI) and from the wood processing association (WPA), and supporting respondents, which consisted of auditors, environmental organisation representatives, academics, and government officials. These respondent groups were chosen due to their strong interests (Krott, 2005) and influences (Steffek, 2009) in forest governance. The questionnaires were divided into 3 types, one each for (i) LC and WPI, (ii) WPA, and (iii) supporting respondents. The questionnaires consisted of two sections. The first, General Information, included the name of the respondent, the type of respondent (type of stakeholder), workplace, and contact information. The second, Stakeholder Preferences, consisted of the respondents' experiences and perceptions of each of the four schemes' characteristics, e.g., their market acceptance, the complexity of their requirements, and the ease with which certificates from each could be obtained. The online questionnaires were distributed in January and February 2015 through personal email, mailing lists, association channels, and social media. Out of 508 personal emails sent 108 replies (21\%), comprising stakeholders from logging companies (23 persons), from the wood processing industry (23 persons), from the wood processing association ( 7 persons), auditors (22 persons), environmental organisation representatives (18 persons), academics (11), and government officials/Ministry of Environment and Forestry employees (4 persons). Eight respondents replied and did not fill the questionnaires due to lack of updated knowledge and company privacy.

\subsection{The Forest Certification Assessment Guide (FCAG)}

The Forest Certification Assessment Guide (FCAG), developed by the World Wide Fund for Nature (WWF) in collaboration with the World Bank (WWF and WB, 2006) was used as a framework in comparing the strength of forest sustainability certification and timber-legality verification schemes currently in use in Indonesia. The FCAG consists of three parts, namely, (1) compliance with international norms and standards, (2) standards and the standard-setting process, and (3) conformity assessment, certification, and accreditation. Within these parts there are 11 criteria and 55 requirements based on the Global Forest Alliance requirements and criteria. The FCAG, which tends to financial institutions' views, also acknowledges other existing standards for conformity assessment, such as the International Organization for Standardization (ISO) or the International Social and Environmental Accreditation and Labelling (ISEAL) Alliance. Hence, although FCAG was formulated 
by the WWF, a proponent of FSC, one of the certification schemes assessed in this study, the FCAG framework is internationally accepted and used by analysts (for example, Hinrichs and Prasetyo, 2007; Maryudi, 2009; Walter, 2006, 2011) in comparing contested schemes. In this study, each scheme (FSC, IFCC, LEI and SVLK) was analysed against the requirements of the FCAG framework. Evaluation focussed on forest management standards and systems established by these schemes in the Indonesian context. The analysis was carried out as a desk study, based on the publicly available documentation of the schemes as well as key literature (see: Empirical materials). Furthermore, it assessed the schemes' ability to satisfy the FCAG framework scored as: fulfilled (1 point), partly fulfilled ( 0.5 point), not fulfilled ( 0 point), and not applicable (-). The schemes were graded according to their scores to determine which best conformed to the FCAG criteria, even though better schemes are not always the most suitable for small and medium forest growers. 


\section{Research Results}

\subsection{Economically viable and international forest issues are a greater concern for state bureaucracies}

Three new bureaucracies, namely the National Council on Climate Change (Dewan Nasional Perubahan Iklim or DNPI), the Presidential Delivery Unit for Development Monitoring and Oversight (Unit Kerja Presiden Bidang Pengawasan dan Pengendalian Pembangunan or UKP4), and the REDD+ Agency were established by President of Indonesia to assist the Ministry of Forestry in tackling prolonged forest problems. However, based on deliberation in public and expert spheres, Wibowo and Giessen (2015a) found that those bureaucracies paid the most attention to economically viable and international forest issues, and paid less attention to issues of environmental value. Surprisingly, the Ministry of Trade was involved in three out of seven issues identified (Table 4), signalling that forest resources are still influential in economic development and in Indonesia's foreign trade.

Table 4: Main forest related issues and major state agencies involved

\begin{tabular}{|c|l|l|}
\hline No. & Forest related issues & State agencies involved \\
\hline 1 & Timber legality & $\begin{array}{l}\bullet \text { Ministry of Forestry } \\
\bullet \text { Ministry of Trade }\end{array}$ \\
\hline 2 & Climate change, including REDD initiative & $\begin{array}{l}\bullet \text { Ministry of Forestry } \\
\bullet \text { UKP4 }\end{array}$ \\
\hline 3 & Oil palm plantation and its environmental aspects & $\begin{array}{l}\bullet \text { Ministry of Forestry } \\
\bullet \text { Ministry of Trade }\end{array}$ \\
\hline 4 & Harmonisation of wood and forest certification schemes & $\begin{array}{l}\bullet \text { Ministry of Forestry } \\
\bullet \text { Ministry of Trade }\end{array}$ \\
\hline 5 & Land use change & $\begin{array}{l}\bullet \text { UKP4 and REDD Agency } \\
\bullet \text { Ministry of Forestry }\end{array}$ \\
\hline 6 & Forest and species conservation & $\bullet$ Ministry of Forestry \\
\hline 7 & Deforestation and decentralized forest governance & $\begin{array}{l}\bullet \text { Ministry of Forestry } \\
\bullet \text { Local governments }\end{array}$ \\
\hline
\end{tabular}

Note: Issues 1-3 are identified as primary issues, whereas issues 4-7 are secondary.

Source: Wibowo and Giessen (2015a, 2015b).

Wibowo et al. (2015c) offer three reasons to support this conclusion. First, Indonesia received international grants of 178.5 million USD $^{1}$ for 36 projects in 2013, equivalent to $28 \%$ of the Ministry of Forestry's budget in the same year (Ministry of Forestry, 2014). Hence, international donors play a significant role in directing national forest agendas by state agencies. Second, the Ministry of Forestry has an organisational interest, which is to try to restore its existence in domestic politics by influencing people along the timber value chain and to show that SVLK is able to increase Indonesia's timber export value (Wibowo et al., 2015a; Wibowo et al., 2015b). It also tries to gain the acknowledgement of global forest stakeholders by being the agency in charge of the EU-Indonesia FLEGT-VPA process. Participation of the Ministry of Forestry in the international forest agenda will help to define its existence as the agency which is responsible for over two third of the state's land, something which

\footnotetext{
${ }^{1}$ The average exchange rate for 1 USD in 2013 was 10.445 IDR.
} 
has been threatened lately by other state agencies through pro-environmental development agendas such as climate change and green development streams.

These findings agree with Resosudarmo et al. (2013) and Edwards et al. (2014), who stated that it was the intention of the President of Indonesia to show the world that Indonesia had been making many efforts to tackle forest problems that are frequently highlighted by environmentalists as well as to deny accusations, by the NGOs, of it being a forest destroyer. The signing of the EU-Indonesia FLEGTVPA by the Ministry of Forestry could also be seen as an attempt to boost the country's new image as a legal timber producer, although in fact there is a not significant change in domestic timber regulation. Wiersum and Elands (2013) state: "the FLEGT-VPA process mainly concerned a further adaptation of the already existing Indonesian timber legality policy which has a traditional timber sector orientation."

In fact, McDermott (2014) noted that international forest governance in the last decade has evolved through three phases (Figure 1), namely, from certification of sustainable forest management, to the regional timber legality initiative, and then to the Reducing Emissions from Deforestation and Degradation and forest enhancement (REDD+). The change in each phase is a result of its evaluation and improvement. To date there is little evidence to show that REDD+, as the latest global forest regime wave, has allowed actors to reach their initial goals successfully (McDermott, 2014; Harada et al., 2015; Luttrell et al., 2014). In this regard, it has been argued that the Ministry of Forestry and other agencies in charge of forests followed international trends in handling the forest-related agenda (Sahide et al., 2015b, under review; Giessen et al., 2015, under revision).

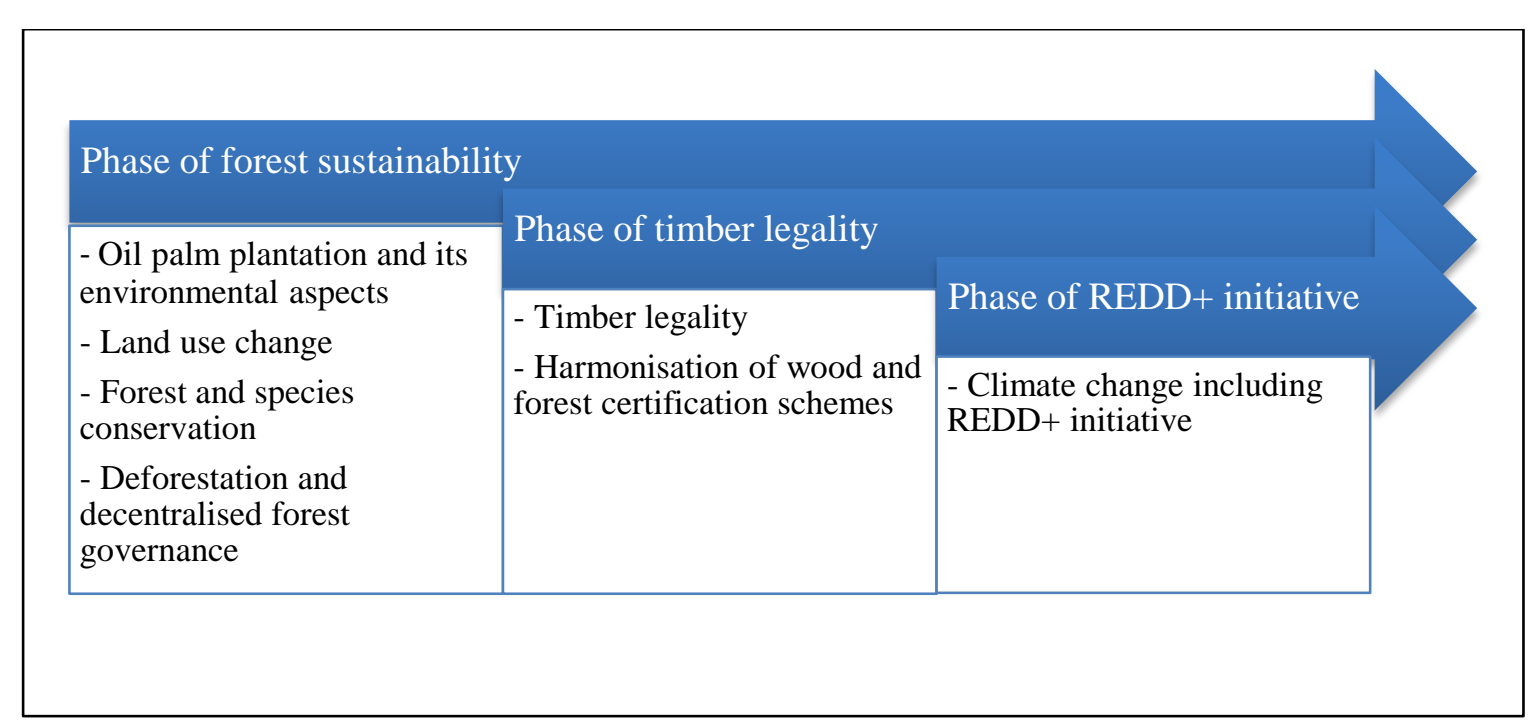

Figure 1: Phases in international forest governance and corresponding issues adopted by the Ministry of (Environment) and Forestry

Source : McDermott (2014), Wibowo and Giessen (2015a)

\subsection{State actors reclaiming timber trade governance}

Our results show that currently there are three forest sustainability certification schemes (FSC, LEI, and PEFC) and one timber legality verification (SVLK) in use in Indonesia, where each represents one type of forest governance (Table 5). Wibowo et al. (2015a) point out that "Due to the lack of capital, human resources and interest affinity, the hybrid private-public government will disappear, and the FMUs and wood industries will make alliances with the government to support traditional forest 
governance. Consequently, there will be only two certification schemes competing for the market in the future, namely, the pro-environment and pro-business schemes. The first scheme is represented by FSC and LEI, and the pro-business scheme consists of SVLK and PEFC."

Table 5: Key features of the types of forest certification scheme in Indonesia

\begin{tabular}{|l|l|l|l|l|}
\hline Key features & $\begin{array}{l}\text { Environmentally- } \\
\text { private governance } \\
\text { (FSC) }\end{array}$ & $\begin{array}{l}\text { Hybrid private- } \\
\text { public governance } \\
\text { (LEI) }\end{array}$ & $\begin{array}{l}\text { Producer-private } \\
\text { governance } \\
\text { (PEFC) }\end{array}$ & $\begin{array}{l}\text { State } \\
\text { governance } \\
\text { (SVLK) }\end{array}$ \\
\hline Rule makers & Environmentalists & Academics & Land owners & Government \\
\hline State involvement & No & Partially & Limited & Full \\
\hline Supporting actor & ENGOs & No & Industry & Government \\
\hline Territorial focus & International & National & International & National \\
\hline Auditor & Third party & Third party & Third party & Third party \\
\hline Public examination & Yes & Yes & Yes & Yes \\
\hline $\begin{array}{l}\text { Certificate } \\
\text { acceptability }\end{array}$ & International & National & International & EU and national \\
\hline Brand image & Strong & Weak & Quite strong & Weak \\
\hline $\begin{array}{l}\text { Industry } \\
\text { participation }\end{array}$ & Voluntary & Voluntary & Voluntary & Mandatory \\
\hline $\begin{array}{l}\text { Actor involved } \\
\text { Law enforcement }\end{array}$ & B to B & B to B & B to B & G to G and B to \\
\hline
\end{tabular}

Source: Wibowo et al. (2015a).

Competition among the four schemes has become intense since the Ministry of Forestry made SVLK mandatory for all FMUs and timber manufacturers, and asked the Ministry of Trade to impose legality certification as one requirement for timber export. Through both regulations, the Ministry of Forestry makes itself the main timber regulator and expands its authority to all timber stakeholders. Wibowo et al. (2015a) analyse this and conclude that the Ministry of Forestry strives for three benefits, namely: (i) increasing its presence in downstream industry circles by financing the first SVLK-certification process for small enterprises, (ii) compelling the enterprises to choose SVLK only or either SVLK and private schemes for cost efficiency reasons, and (iii) making SVLK better known and legitimate in domestic and overseas markets.

Competition among forest certification schemes is normal and widely observed in Sweden (Gulbrandsen, 2005), Canada, the United States, Germany (Cashore et al., 2005b), and Russia (Malets, 2015). However, the trend of reclaiming authority over private governance only happens in tropical countries such as Ghana, Republic of Congo, Cameroon, the Central African Republic, Liberia, and Indonesia (Overdevest and Zeitlin, 2014). Nurrochmat et al. (2015b) report that ASEAN countries are now trying to establish a set of regional principles for timber trading inside the region and use FLEGT-VPA of each country as a basis for these principles. The states, apparently, try to deceive market that already aware with environmentally friendly products created by private schemes, but do not care whether the products' labelling indicates that they are associated with a pro-environmental or a pro-business scheme. The states benefit from the financial inability of timber producers and manufacturers to pay multiple certification schemes. 


\subsection{International influences changing domestic power structures and interactions}

The establishment of DNPI and the REDD+ agency, which took power from the Ministry of Forestry, cannot be separated from the international influences (Wibowo and Giessen, 2015b). DNPI was introduced in 2008 after Indonesia hosted the $13^{\text {th }}$ Conference of the Party of UNFCCC in 2007 as an answer to the need for an agency that would report Indonesia's National Communications to the UNFCCC and would be responsible for monitoring the country's emission reduction, while the REDD+ Agency was introduced to fulfil the requirements included in the letter of intent between Indonesia and Norway (see: The Government of the Kingdom of Norway and the Government of the Republic of Indonesia, (2010). Wibowo and Giessen (2015b) show that the DNPI and the REDD+ Agency together took 54\% of strategic tasks on REDD+ Programme, compared to the Ministry who get only $9 \%$ of strategic tasks. The new agencies also increased competition for international political support and neither provides its competitor with assistance in the programme for which it is not responsible. An example of this can be observed in that the Ministry of Forestry has kept exclusive access to its dominant information -it only shares 17 of 29 thematic maps it produces- and in that it has used the dominant information it has as a source of power when there have been systematic attempts to reduce its power.

Moeliono et al. (2014) have also observed similar behaviour, which revealed that the most influential actors in the REDD+ Programme in Indonesia tended not to seek or obtain information from other actors, and that the information exchange between them was weak. Wibowo and Giessen (2015b) add, "This dearth of information exchange indicates that each bureaucracy does not want to open its agenda regarding policy formulation and will expose it to the public only when it is complete." According to Krott et al. (2014), giving dominant information to the opponent may increase their power and harm one's own agenda.

\subsection{Bureaucracies and super-bureaucracies}

Our study on international forest politics in Indonesia distinguishes between bureaucracies and superbureaucracies in forest resource management, as ilustrated in Figure 2. Initially, one may earn one's livelihood by oneself. Simple delegation from authorised person to subordinate then needs to manage the distribution of wealth. Increasingly, the subordinate becomes more independent in the management of resources under his authority and a supra-bureaucracy is created by authorised person of highest rank in order to control and supervise the use of resources.

The creation of UKP4 by the President of Indonesia is the means he used to control the balance of power of bureaucracies -including the Ministry of Forestry, which became more independent over time. Complaints by researchers, bureaucrecies, local people, ENGOs, and international actors concerning the poor forest governance practiced by the Ministry of Forestry led the president to give UKP4 more authority to supervise and lead forest governance reformation (Wibowo and Giessen, 2015b). Under the coordination of UKP4, the government postponed the issuance of new business permits in production forests, assigned to the Ministry of Environment responsibility for primary forest and peatland areas, designated BIG as the coordinator for technical aspects in the One Map initiative, and appointed itself as the leading agency for the One Map initiative. However, the power of UKP ended when the new President dissolved UKP4, DNPI and the REDD+ Agency, and empowered the Ministry of Forestry by merging it with the Ministry of Environment. This shows that creating 
(and disbanding) a new and super-bureaucracy with limited staff, dominant information, and a budget is easy (Helperin and Clapp, 2006) and that it is not an effective way to manage millions of hectares of state forests. On the contrary, the problems in immense forest governance will exist whenever all bureaucracies wield the the same level of power, and there is no powerful and single leading agency in charge (Sulistiawati, 2013).

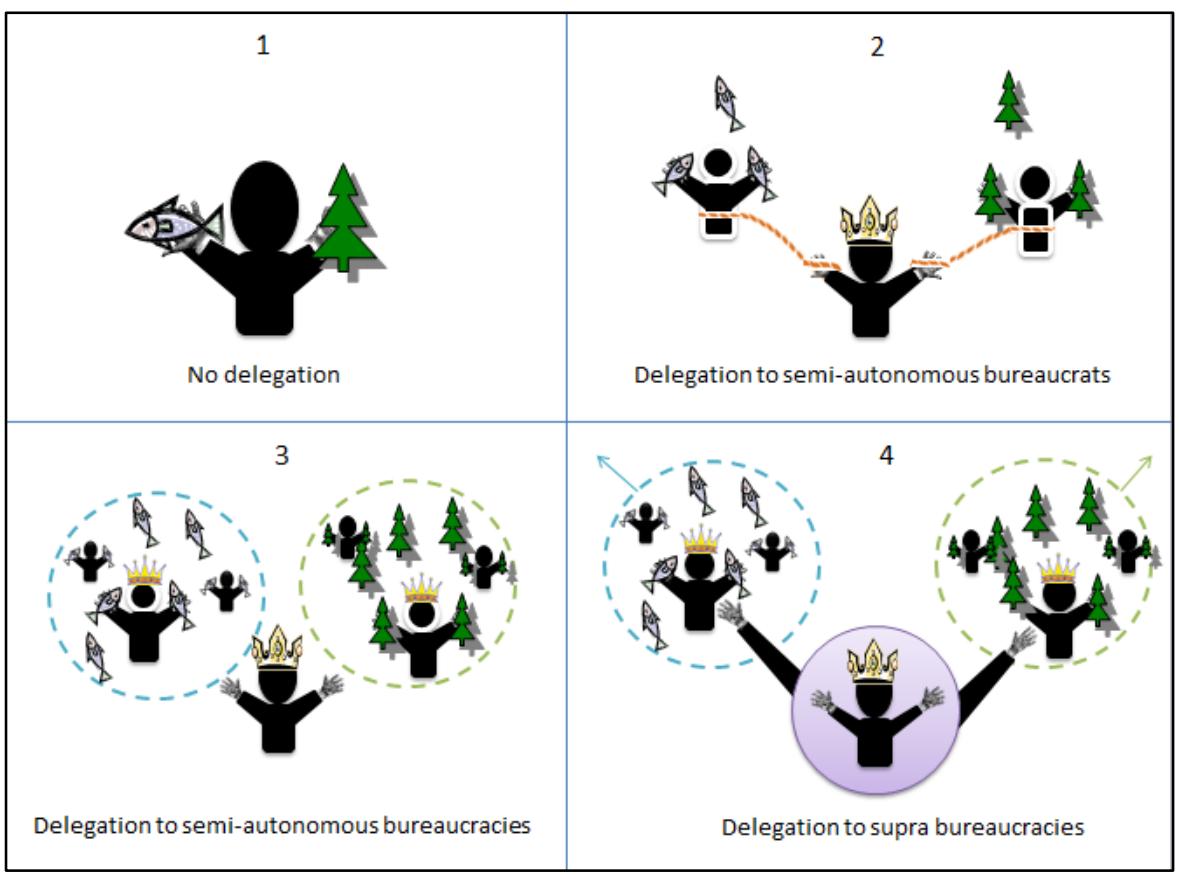

Figure 2: The forming of supra-bureaucracy

\subsection{SVLK, REDD+ and One Map Policy as symbolic policies?}

Wibowo and Giessen (2015a) point out that the timber legality verification system (SVLK) is one of the most discussed policies by the Ministry of Forestry, since it guarantees that timber products which have already passed SVLK verification and have obtained the V-Legal/FLEGT license are then automatically legal, making it easier for them to enter the EU market. Indonesia's REDD+ programme, on the other hand, is known as an ambitious policy since President Yudhoyono announced, in 2009, that the country intended to reduce its carbon emissions by $26 \%$ and that, with international contributions, it may increase its rate reduction by up to $41 \%$ by 2020 . Similar, with only $16.6 \%$ of forest mapped area had been gazette by the Ministry of Forestry in 2012; it is difficult to whole stakeholders to agree One Map for all development agenda. The three policies quickly drew the attention of forest stakeholders who pointed out their pros and cons. Business groups, environmentalists, academics, and the EU actually fully supported SVLK before the Ministry of Forestry made it obligatory for all timber producers and processing industries (Wibowo and Giessen, 2015a). Uncertainty regarding SVLK implementation reached its peak when business group lobbyists successfully forced the Ministry of Trade to loosen timber export provisions by allowing furniture producers to use self-declaration on timber legality to replace the V-Legal document just three days before the SVLK implementation planned by the Ministry of Forestry, on 1 January 2015 (Ministry of Industry, 2014). Similarly, environmental NGOs and researchers questioned how Indonesia could reach its target in the midst of the complexity of forest governance at the national level and of numerous unresolved forest land conflicts in Sumatra and Kalimantan (Wibowo and Giessen, 2015b). 
Given the presentation of many refutations from business groups and other ministries regarding the adequacy of SVLK, and limited progress on the REDD+ programme, Wibowo and Giessen (2015b) consider both to be examples of symbolic policy, or non-policy in a sense, one which, beyond formulating goals and creating instruments, is not endowed with clear responsibilities to implement agencies, hire sufficient staff, budget resources and manage all necessary information. Other authors have written on similar ideas (Krott et al., 1990; Krause, 2011; Edelman, 1977). This conclusion is based on the fact that REDD+ policy, and also SVLK, are based on weak legal constructions, have no single strong leading agency responsible for ensuring continuity and have only weak long-term agendas with no stand-alone budgets or discrete staff (Wibowo and Giessen, 2015b). A weak legal construction means that the policy could be changed, postponed or discontinued by other powerful actors, while the lack of a leading agency means that there is no actor with enough power to direct and implement the policy or with the authority to penalize whoever is against it.

Hesitation regarding SVLK was also found among scientists although some (e.g. Dharmawan et al., 2012) try to ensure that SVLK can bring the country towards better forest governance. Nurrochmat et al. (2014) conclude that "implementing SVLK standards amid multiple forest regimes causes redundancy of administrative procedures in forest management and timber trade in Indonesia" and "leads to decrease in cost efficiency, weak legitimation, and low effectiveness of the system, especially in community forests". In response to these obstacles, Maryudi et al. (2015) call for SVLK deregulation for smallholder forests. In contrast, Wijaya et al. (2012) pushed the Ministry of Forestry to strengthen the ecological and social aspects of the SVLK standard in order to reach sustainable forest management. Mulyaningrum et al. (2013) allege that there are difficulties in implementing SVLK, since the Ministry of Forestry is too dominant in its formulation of SVLK and uses its coercive power as a state agency.

Reports on REDD+ practices on the ground come to identical conclusions. For example, Purnomo et al. (2012) observe that "REDD+ policy in Jambi needs to be simplified by, among other things, providing better quality of space for local initiatives, showing real benefits to actors, and reducing complexity by developing a super body." Similarly, Rochmayanto (2013) argues that REDD+ implementation in Riau faces a high risk of failure due to the potential for social conflict and corruption, uncertainty in land use rights, and administrative constraints.

\subsection{Contrasting forest certification with legality verification}

Competition between forest certification schemes and legality verification affect stakeholders' perceptions and the industries that use the schemes in timber trading. Our three studies reveal that (i) state-driven certification scheme is likely to take the lead over the private ones (Wibowo et al, 2015a); (ii) a better certification scheme is not always preferred by the timber industry (Wibowo et al., 2015b, 2015d), and that (iii) industry prefers to use SVLK as it is mandatory, and using it can avoid double charges in the certification process (Pratiwi et al., 2015). A brief explanation of these findings follows.

As mentioned in section 4.2, each certification scheme that currently exists in Indonesia is at one type of forest governance, namely environmental-private governance (FSC), hybrid private-public governance (LEI), producer-private governance (PEFC), and state governance (SVLK). Based on the nature of the various proponents and their interests we argue that in the future those schemes will simply gravitate towards two types: pro-environment schemes (FSC and LEI) and pro-business schemes (PEFC and SVLK). This claim is based on the fact that FSC and LEI were established and ruled by pro-environmentalists and denied state involvement in the whole process of certification and 
organisation. In contrast, PEFC and SVLK were established by the business sector that was supported by the governments and intended to secure their domestic and foreign market from "well certified timber." Law enforcement mechanisms proposed by the pro-business scheme will force all industry figures to engage with them, eroding all opponents.

The evaluation of the four schemes shows that FSC fulfils almost 100\% of FCAG requirements and is identified as the best scheme, followed by PEFC, LEI and SVLK. Our study (Wibowo et al., 2015b) shows that firms do no automatically choose the ideal scheme for improving forest governance and enhancing business. Pratiwi et al. (2015) finds that about $60 \%$ of respondents from the processing industry acknowledge that the FSC is a necessary scheme for Indonesia, followed by SVLK (13\%), LEI (12\%), and PEFC (9\%). However, respondents from logging companies and the wood-processing industry prefer to be certified under the SVLK (48-57\%), followed by the FSC (43-48\%), the PEFC (13-43\%), and the LEI (9-29\%). This preference is strongly influenced by the mandatory nature of the SVLK, government subsidies, and market acceptance.

Furthermore, statements by each scheme's proponents in the mass media show that all schemes are in competition rather than being complementary. However, it should be noted that the aim of competition is not merely to gain legitimacy and trust in the marketplace (Cashore et al., 2004; McDermott, 2012), and it exists because of different sustainable forest management concepts and norms in each scheme (Maryudi, 2006). 


\section{Strategic Options for Selected Actors}

This dissertation is relevant for the improvement of the performance of two policy actors, namely the Ministry of Forestry and Lembaga Ekolabel Indonesia. Based on the results of the study and recent forest politics trends, this dissertation offers suggestions for them.

\subsection{Strategic options for the Ministry of Environment and Forestry}

The problem facing by the Ministry of Environment and Forestry is that it lost the trust of domestic and foreign stakeholders. Wibowo and Giessen (2015b) write, “... The Ministry of Forestry has been blamed for these forest problems because its policies have frequently been deemed inconsistent, inaccurate, inadequate and unfair. Other negative attributes attributed to the Ministry of Forestry, such as corruption (Nellemann and Interpol Environmental Crime Programme, 2012), a lack of transparency and data openness (Simangunsong, 2004; Brown, 2002) and limited public participation in decision-making processes (Santosa et al., 2013), have caused the public to lose trust in the Ministry." Hence, further policies should respect other actors and interests. The following are some strategic options for future forest development.

First, future programmes should be designed with a long term and permanent agenda in mind. Since the new president, or Minister of Environment and Forestry or other bureaucracies can change or discontinue programs created by previous forest officials, this study suggests that the major policies, where the Ministry of Environment and Forestry acts as the leading sector, should be established based on a specific law that can only be changed with the consent of the House of Representatives (parliament). The creation of a statute may require a long time and split task of the Ministry of Environment and Forestry, but it gives credence to the planned program.

Second, public trust should be improved by providing transparency and data openness. The 2008 Information Law actually asks all Ministries to produce accurate, complete, and updated information, and forces them to disclose it to the public. However, what kind of data should be produced and what should be shared are up to the Ministry. Opening data to the public can increase the Ministry's legitimacy, but it has a cost in terms of a reduction of the informational power element.

Third, degraded and deforested areas should be converted to other development uses and there should be a focus on the development of conservation and protection forests, through programmes such as ecotourism and environmental services. The Decree of Constitutional Court No. 35/PUU-X/2012, which excludes customary forests from state forests and returns their management to indigenous people, and the One Map Initiative, could be a way to reduce significantly the size of the forest area to be managed by the Ministry. Although the conversion cannot automatically solve forest problems, at least it gives people access to the land in order to make it more productive, increasing their prosperity, and it provides more options for other development programmes. It also prevents the Ministry from becoming a scapegoat when forests are damaged.

\subsection{Strategic Options for Lembaga Ekolabel Indonesia (LEI)}

Lembaga Ekolabel Indonesia (LEI) is a non-profit and constituent-based organisation the mission of which is to develop a credible forest and biodiversity certification scheme, to support sustainable and prosperous policies on natural resource management, and to support good models of natural resource 
management for its constituents and customary people (LEI, 2014). To implement this mission, LEI developed a certification scheme for forests, non-timber forest products, a timber chain of custody, and it established social and environmental standards for REDD+ implementation, and for the accrediting certification bodies (LEI, 2014). Although it has a wide range of certification schemes, the total forest area and companies it has certified since 2009 has tended to stagnate. This has been attributed to a close competition against other forces. Below are short explanations and map (Figure 3) describing competing forces.

(1) Existing schemes

- FSC. Some independent researchers (e.g., Gulbrandsen, 2004; Wibowo et al., 2015b, 2015d) point out that the FSC has better standards for achieving sustainable forest management. The FSC scheme is preferred by timber processing industries, as indicated by the number of its CoC certificates, which is almost three times higher than those of PEFC (UNECE and FAO, 2013, p.20). This figure supports the idea that the motive industrial groups have for becoming certified is to satisfy their business partners and the market.

- PEFC. PEFC certificates are preferred by logging industries and forest owners, as shown by its market share in 2014, which was about 255 million hectares (PEFC, 2014) as compared to the FSC-certificate forest area, which was about 182 million hectares for the same year (FSC, 2014). This supports the notion that PEFC was dedicated for forest owners.

- SVLK. The compulsory nature of SVLK makes for securing the market, namely upstream and downstream timber industries (Wibowo et al., 2015a). The benefit of SVLK-certified timber products was confirmed by the yearly increase of timber export value to Europe, from 5.4 million dollars in the middle of 2013 to 11 million dollars by the middle of 2014 (ITTO, 2014).

- LEI. The progress of LEI certified-forest areas has been stagnant since its appearance in 1998. LEI seems to be complementary to other schemes and forest and timber companies only use it to enhance their business performance, before adopting other certification schemes. LEI, however, has extensive experience in the formulation of certification standards for forest management.

(2) ISO-CoC scheme. The International Organization for Standardization (ISO) plans to establish $\mathrm{CoC}$ standards for wood and other lignin material (e.g., timber, bamboo) to reduce the cost of multi-certification schemes (IHB, 2013), though this plan has been rejected by FSC and PEFC (FSC and PEFC, 2013). In 2014, 17 countries participated in the formulation of an ISO-CoC standard, and 18 other countries were observers (ISO, 2014).

(3) Substitutive service. Refusal of non-certified tropical timber is often seen as a technical trade barrier and protectionism benefitting non-tropical timber. However, the business continues to run due to the absence of complaints submitted to the WTO. Tallontire and Blowfield (2000) reveal that FLEGT-VPA has the potential to violate trade agreements under the WTO, and could possibly be cancelled if it is found to be a cause of unfair trade against some parties.

(4) Forest and timber industries. The companies consider for adoption only those schemes with wider acceptance in their next value chain, and avoid those that cannot improve their images (Nurrochmat and Yulianti, 2013). Rejection of SVLK-certified pulp by paper companies (The Jakarta Post, 2014) shows that the market is rational and cannot be driven by the law. This also happened in the US and Europe, and eliminated local schemes.

(5) Buyers. Normally, buyers choose quality and lower price products. However, about $73 \%$ of them are willing to pay a $12 \%$ higher price for certified products (Elliott, 2014). Thus, the popularity of certification schemes also determines buyers' decisions. 


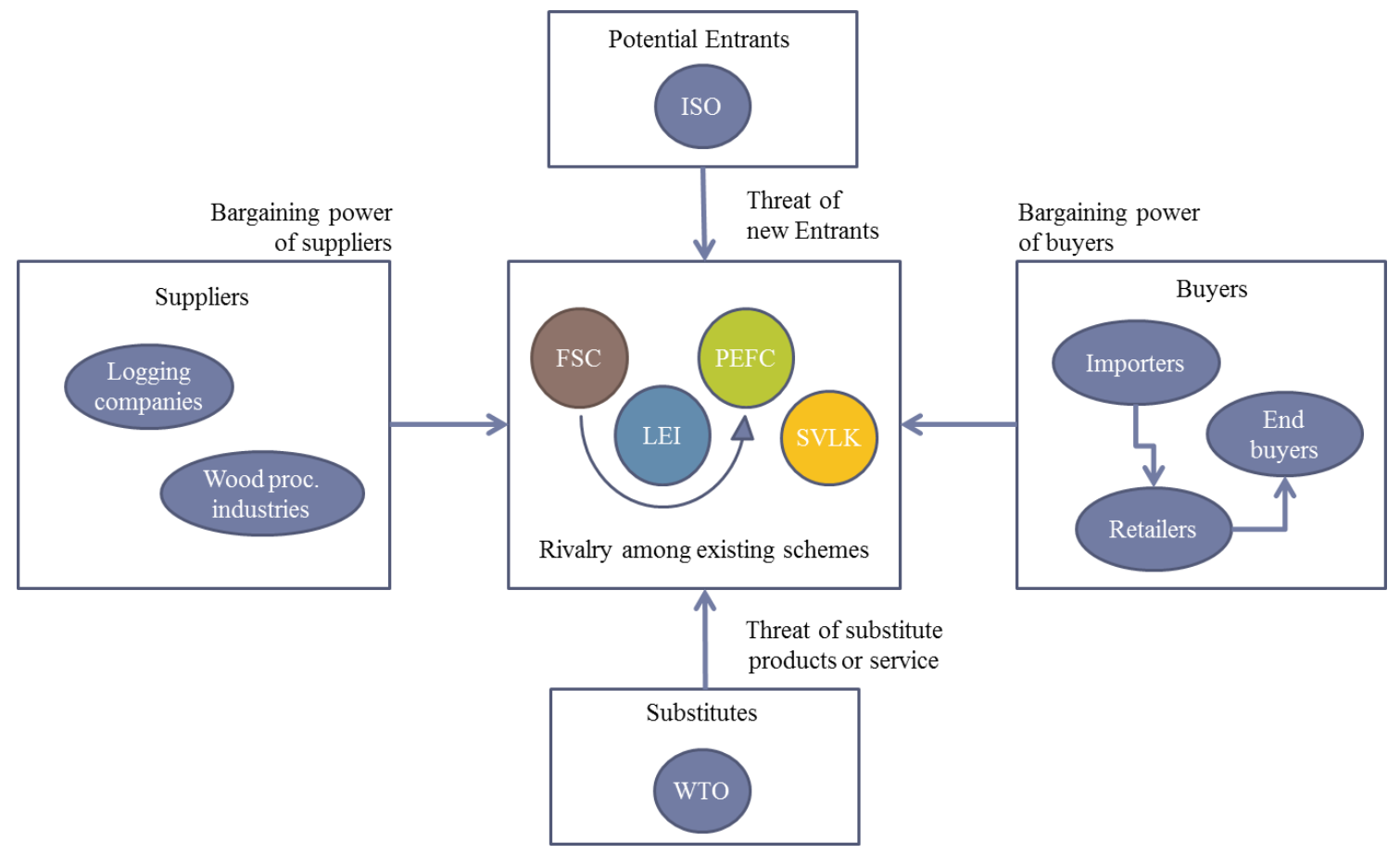

Figure 3: Competing forces in the forest certification business in Indonesia (adapted from Porter, 2008)

In fact, the existing conditions of the LEI are as follows:

1. The members consist of four chambers (eminent persons, indigenous people, business, and NGOs) with different backgrounds and various interests;

2. LEI has no power to force the market to engage with it (as SVLK has);

3. LEI is an organisation at the national level which competes for a market share against international organisations and a state-supported mechanism;

4. LEI is experienced in establishing certification schemes for timber and forest.

Based on the notions above, the following are strategic options that LEI may choose in order to continue working in the certification field.

(1) Cooperating with FSC. LEI cooperated with FSC when they agreed to a joint certification protocol in 1999. Nowadays LEI can be the FSC-standard development group and provided recommendations for the revision of the FSC-International Generic Indicator. This is possible since LEI already has standards for forest management and timber $\mathrm{CoC}$ that are compatible with the Indonesian context.

(2) Becoming a standard development group (SDG) for non-timber/forest or other biological commodities (e.g., rubber, cacao, and rattan). Until now, on-farm management standards for those commodities are still unavailable, although they have long been cultivated in the country.

(3) Becoming a partner of the National Standard Agency (BSN) to discuss ISO Standards. In this case, LEI may provide input to the Agency so that the standards introduced by the ISO do not disserve national interests.

The three options above require LEI to cooperate closely and form an alliance with one competing force, which is likely to benefit one of its member groups and be a disadvantage for other members. Global tendencies in the forest certification business reveal that local schemes can only exist in this field if they engaged with FSC or PEFC, as the two most powerful schemes (UNECE and FAO, 2013). 
This dissertation, on the other hand, hypothesizes that state-supported schemes will surpass the private ones in importance. Any option taken by LEI to stay in the forest certification business seems to affect its organisational form and membership. 


\section{References}

Allison, G. T., \& Zelikow, P. (1999). Essence of decision: Explaining the Cuban missile crisis (Vol. 2). Longman.

Arts, B., \& Van Tatenhove, J. (2004). Policy and power: A conceptual framework between the 'old'and 'new' policy idioms. Policy sciences, 37(3-4), 339-356.

Bachrach, P., \& Baratz, M. S. (1962). Two faces of power. American political science review, 56(04), 947-952.

Bauer, S., Andresen, S., \& Biermann, F. (2012). International bureaucracies. Global Environmental Governance Reconsidered, 27-44.

Bernstein, S., \& Cashore, B. (2000). Globalization, four paths of internationalization and domestic policy change: the case of ecoforestry in British Columbia, Canada. Canadian Journal of Political Science/Revue canadienne de science politique, 33(01), 67-99.

Bernstein, S., \& Cashore, B. (2012). Complex global governance and domestic policies: four pathways of influence. International Affairs, 88(3), 585-604.

Biermann, F., \& Pattberg, P. H. (2012). Global environmental governance reconsidered. MIT Press.

Blais, A., \& Dion, S. (1990). Are bureaucrats budget maximizers? The Niskanen model \& its critics. Polity, 655-674.

Brown, D.W. (2002). Secrecy in the Indonesian forest products sector: a researcher's experience. In: Indonesia, F.W., Watch, G.F. (Eds.). The State of the Forest: Indonesia. Forest Watch Indonesia, Bogor, Indonesia, and Global Forest Watch, Washington DC, pp. 79-80.

Burns, S. L., \& Giessen, L. (2014). Identifying the main actors and their positions on international forest policy issues in Argentina. Bosque, 35(2), 163-173.

Cashore, B. (2002). Legitimacy and the privatization of environmental governance: How non-state market-driven (NSMD) governance systems gain rule-making authority. Governance, 15(4), 503-529.

Cashore, B., \& Van Kooten, G. C., Vertinsky, I., Auld, G., \& Affolderbach, J. (2005). Private or selfregulation? A comparative study of forest certification choices in Canada, the United States and Germany. Forest Policy and Economics, 7(1), 53-69.

Chasek, P. S., Downie, D. L., \& Brown, J. (2013). Global environmental politics. Westview Press.

Dahl, R. A (1957). The concept of power. Behavioral Science, 2 (3), 201-215.

Dawson, C. (2003). Creating Borders on the Internet: Free Speech, the United States, and International Jurisdiction. Va. J. Int'l L., 44, 637.

Dharmawan, A. H., Nugroho, B., Kartodihardjo, H., Kolopaking, L. M., \& Boer, R. (2012). SVLK, Jalan Menuju REDD+. Forest Governance and Multistakeholder Forestry Programme, Ministry of Forestry Indonesia-UK Department for International Development.

Edelman, M. (1977). The language of participation and the language of resistance. Human Communication Research, 3(2), 159-170.

Edwards, D. P., Koh, L. P., \& Laurance, W. F. (2012). Indonesia's REDD+ pact: Saving imperilled forests or business as usual?. Biological Conservation,151(1), 41-44.

Elliot, J. (2014). An analysis of willingness to pay and reasons for purchasing certified forest products. Master Thesis. Duke University. North Carolina. US.

Faggi, A.M., Zuleta, G.A. \& Homberg, M. (2014). Motivations for implementing voluntary environmental actions in Argentine forest companies. Land Use Policy 41:541-549.

Fenno, R. F. (1986). Observation, context, and sequence in the study of politics. American Political Science Review, 80(01), 3-15.

FSC (Forest Stewardship Council) \& PEFC (Programme for the Endorsement of Forest Certification) (2013). Joint statement by the Forest Stewardship Council (FSC) and the Programme for the Endorsement of Forest Certification (PEFC) recommending ISO member to vote against the new work item proposal Chain of Custody of Forest Based Products-Requirements. http://www.pefc.org/images/documents/external/Joint_Statement_FSC_PEFC_July_8_2013.pdf. [Accessed 12 June 2014]. 
FSC (Forest Stewardship Council) (2014). FSC harmonised certification bodies' Forest Stewardship Standard for the Republic of Indonesia. http://www.scsglobalservices.com/files/standards/fscstd-idn-01-01-2013_indonesianatural_plantations_and_slimf.pdf [Accessed 14 December 2014].

Giddens, A. (1984). The constitution of society: Outline of the theory of structuration. Univ of California Press.

Giessen, L. (2011). Reviewing empirical explanations of policy change: Options for its analysis and future fields of research. Allgemeine Forst-und Jagdzeitung, 182(11/12), 248-259.

Giessen, L., Krott, M., \& Möllmann, T. (2014). Increasing representation of states by utilitarian as compared to environmental bureaucracies in international forest and forest-environmental policy negotiations. Forest Policy and Economics, 38, 97-104.

Giessen, L., Burns, S., Sahide, M.A.K., \& Wibowo, A. From transnational governance to international government regimes in forest and agricultural certification: The key role of state bureaucracies for private governance in Argentina and Indonesia. Policy \& Society, under revision.

Glück, P., Angelsen, A., Appelstrand, M., Assembe-Mvondo, S., Auld, G., \& Hogl, K. (2010). Core components of the international forest regime complex (Vol. 28, pp. 37-55). IUFRO.

Gulbrandsen, L. (2003). The evolving forest regime and domestic actors: strategic or normative adaptation?. Environmental Politics, 12(2), 95-114.

Gulbrandsen, L. H. (2004). Overlapping public and private governance: Can forest certification fill the gaps in the global forest regime? Global Environmental Politics, 4(2), 75-99.

Gulbrandsen, L. H. (2005). Sustainable forestry in Sweden: the effect of competition among private certification schemes. The Journal of Environment \& Development, 14(3), 338-355.

Halas, M. (2008). Relative and absolute gains problem in international relations. In: Paraskakis, I., Luneski, A. (Eds.), East European Doctoral Student Conference. South-East European Research Centre, pp. 375-385.

Halperin, M. H., \& Clapp, P. (2006). Bureaucratic politics and foreign policy. Brookings Institution Press.

Harada, K., Prabowo, D., Aliadi, A., Ichihara, J., \& Ma, H. O. (2015). How Can Social Safeguards of REDD+ Function Effectively Conserve Forests and Improve Local Livelihoods? A Case from Meru Betiri National Park, East Java, Indonesia. Land, 4(1), 119-139.

Harrison, L. (2013). Political research: an introduction. Routledge.

Haugaard, M. (2012). Rethinking the four dimensions of power: domination and empowerment. Journal of Political Power, 5(1), 33-54.

Helm, C., \& Sprinz, D. (2000). Measuring the effectiveness of international environmental regimes. Journal of Conflict Resolution, 44(5), 630-652.

Hinrichs, A., \& Prasetyo, A. (2006). Forest certification credibility assessment in Indonesia: Applying the Forest Certification Assessment Guide at the national level. World Bank/WWF Alliance for Forest Conservation and Sustainable Use, Washington, DC, USA. http://www.lei.or.id/files/download_Guide_a9c8b6.pdf [Accessed 12 June 2015].

Howlett, M., Ramesh, M., \& Perl, A. (1995). Studying public policy: Policy cycles and policy subsystems (Vol. 163). Oxford University Press.

Hsieh, H. F., \& Shannon, S. E. (2005). Three approaches to qualitative content analysis. Qualitative health research, 15(9), 1277-1288.

Humphreys, D. (1999). The evolving forests regime. Global Environmental Change, 9(3), 251-254.

Humphreys, D. (2006). Logjam: Deforestation and the crisis of global governance (p. 302). London: Earthscan.

IHB (2013). ISO approves the new CoC. http://www.ihb.de/wood/news/DIN_PEFC_ FSC_CoC_34218.html. [Accessed 14 January 2015].

ISO (International Standard Organization) (2014). ISO/PC 287 - Chain of custody of wood and woodbased products. http://www.iso.org/iso/home/standards_development/list_of_ iso_technical_committees/iso_technical_committee_participation.htm?commid=495230.

[Accessed 14 January 2015].

ITTO (International Tropical Timber Organization). (2014). Tropical Timber Market Report. Volume 18 Number 16, 16th - 31st August 2014. https://itto-d2.r-cms.jp/files/user/mis/ MIS\%201631\%20Aug\%202014.pdf. [Accessed 14 January 2015]. 
Johansson, J., \& Keskitalo, E. C. H. (2014). Coordinating and implementing multiple systems for forest management: implications of the regulatory framework for sustainable forestry in Sweden. Journal of Natural Resources Policy Research, 6(2-3), 117-133.

Kasa, S. (2013). The Second-image reversed and climate policy: How international influences helped changing Brazil's positions on Climate Change. Sustainability, 5(3), 1049-1066.

Krause, R. M. (2011). Symbolic or substantive policy? Measuring the extent of local commitment to climate protection. Environment and Planning C: Government and Policy, 29(1), 46-62.

Krott, M., Glück, P., Whitby, M.C., \& Dawson, P.J., (1990). Forest land use policy: sym-bolic versus substantial planning. In: Land use for agriculture, forestry and rural development. Proceedings of the 20th symposium of the European Associationof Agricultural Economists (EAAE), July 1989, Newcastle upon Tyne, England. Department of Agricultural Economics and Food Marketing, University of New-castle upon Tyne, pp. 161-168.

Krott, M., Bader, A., Schusser, C., Devkota, R., Maryudi, A., Giessen, L., \& Aurenhammer, H. (2014). Actor-centred power: The driving force in decentralised community based forest governance. Forest Policy and Economics, 49, 34-42.

Krott, M. (2005). Forest policy analysis. Springer Science \& Business Media.

Lozano R. (2013). A holistic perspective on corporate sustainability drivers. Corporate Social Responsibility and Environmental Management; 22:32-44. http://dx.doi. org/10.1002/csr.1325.

LEI (Lembaga Ekolabel Indonesia) (2014). Laporan Kegiatan Lembaga Ekolabel Indonesia 20092014. LEI.

Lindstad, B. H., \& Solberg, B. (2010). Challenges in determining national effects of international policy processes: Forest protection in Norway as a case. Forest Policy and Economics, 12(7), 489-496.

Longhurst, R. (2003). Semi-structured interviews and focus groups. Key methods in geography, 117132.

Lukes, S. (1974). Power: A radical view (Vol. 1). Macmillan.

Luttrell, C., Resosudarmo, I. A. P., Muharrom, E., Brockhaus, M., \& Seymour, F. (2014). The political context of REDD+ in Indonesia: Constituencies for change. Environmental Science and Policy, 35, 67-75. http://doi.org/10.1016/j.envsci.2012.10.001

Malets, O. (2015). When Transnational Standards Hit the Ground: Domestic Regulations, Compliance Assessment and Forest Certification in Russia. Journal of Environmental Policy \& Planning, $17(3), 332-359$.

Maryudi A. (2006). Sertifikasi hutan: Instrumen baru dalam kebijakan kehutanan. Rimba Kalimantan, 11(1): 27-35

Maryudi, A. (2009). Forest certification for community-based forest management in Indonesia: Does LEI provide a credible option?. Hayama-mati (Kanagawa-ken): Institute for Global Environmental Strategies, Forest Conservation, Livelihoods, and Rights Project.

Maryudi, A., Nawir, A. A., Permadi, D. B., Purwanto, R. H., Pratiwi, D., Syofi'i, A., \& Sumardamto, P. (2015). Complex regulatory frameworks governing private smallholder tree plantations in Gunungkidul District, Indonesia. Forest Policy and Economics, 59, 1-6.

McCabe, A. C. (2013). A three-dimensional analysis of power and engaged scholarship. PhD Thesis at the Queensland University of Technology, Queensland, Australia.

McDermott, C. L. (2014). REDDuced: From sustainability to legality to units of carbon-The search for common interests in international forest governance. Environmental Science and Policy, 35, 12 19. http://doi.org/10.1016/j.envsci.2012.08.012

Ministry of Forestry. (2014). Ministry of Forestry Statistics 2013. Ministry of Forestry. Jakarta.

Ministry of Industry. (2014). Press release. Three ministries support export of furniture and handicraft products. http://www.kemendag.go.id/files/pdf/2014/12/29/tiga-menteri-bersatudukung-peningkatan-ekspor-mebel-dan-kerajinan-id0-1419832491.pdf [Accessed 14 March 2015].

Moeliono, M., Gallemore, C., Santoso, L., Brockhaus, M., Di Gregorio, M., 2014. Information networks and power: confronting the "wicked problem" of REDD+ in Indonesia. Ecol. Soc. 19 (2), 9, http://dx.doi.org/10.5751/ES-06300-190209 
Mulyaningrum, M., Kartodihardjo, H., Jaya, I. N. S., \& Nugroho, B. (2013). Stakeholders analysis of policy-making process: The case of timber legality policy on private forest. Journal of Tropical Forest Management, 19(2), 156-162. http://doi.org/10.7226/jtfm.19.2.156.

Nellemann, C., \& Interpol Environmental Crime Programme (Eds.). (2012). Green carbon, black trade: Illegal logging, tax fraud and laundering in the worlds tropical forests. A rapid response assessment. United Nations Environment Programme, GRID-Arendal.

Niskanen, W. A. (1974). Bureaucracy and representative government. Transaction Publishers.

Nurrochmat, D. R., \& Yulianti, F. (2013). Policy options to integrate the domestic timber market into formal economy: case studies of three regencies of Central Java province of Indonesia (No. Working Paper Series no. 3, p. 30). Center for International Forestry Research (CIFOR), Bogor, Indonesia.

Nurrochmat, D. R., Dharmawan, A. H., Obidzinski, K., Dermawan, A., \& Erbaugh, J. T. (2014). Contesting national and international forest regimes: Case of timber legality certification for community forests in Central Java, Indonesia. Forest Policy and Economics. http://doi.org/10.1016/j.forpol.2014.09.008.

Nurrochmat, D. R., Yovi, E. Y., Hadiyati, O., Sidiq, M., \& Erbaugh, J. T. (2015a). Changing policies over timber supply and its potential impacts to the furniture industries of Jepara, Indonesia. Jurnal Manajemen Hutan Tropika, 21(1) 36-44.

Nurrochmat, D.R., Sahide, M.A.K., \& Wibowo, A. (2015b). Stock taking study on existing initiatives for ensuring legal and sustainable timber in ASEAN. ASEAN Secretariat.

Overdevest, C., \& Zeitlin, J. (2014). Assembling an experimentalist regime: Transnational governance interactions in the forest sector. Regulation and Governance, 8(1), 22-48. http://doi.org/10.1111/j.1748-5991.2012.01133.

Patton, M. Q. (2005). Qualitative research. John Wiley \& Sons, Ltd.

PEFC (Programme for the Endorsement of Forest Certification). (2014, November). PEFC Global Statistics: SFM \& CoC Certification. http://www.pefc.org/about-pefc/who-we-are/facts-afigures. [Accessed 18 June 2015].

Peters, G. (2002). Politics of bureaucracy. Routledge.

Peters, B. G. (2010). Bureaucracy and democracy. Public Organization Review, 10(3), 209-222.

Porter, M. E. (2008). Competitive strategy: Techniques for analyzing industries and competitors. Simon and Schuster.

Prabowo, D., Maryudi, A., \& Imron, M. A. (2015). Enhancing the application of Krott et al.'s (2014) Actor-Centred Power (ACP): The importance of understanding the effect of changes in polity for the measurement of power dynamics over time. Forest Policy and Economics. http://doi.org/10.1016/j.forpol.2015.10.006.

Pratiwi, S., Wibowo, A., \& Giessen, L. (2015). Third-party certification of forest management in Indonesia: Analysing stakeholders' recognition and preferences. Journal of Tropical Forest Management, 21(2), 65-75. http://doi.org/10.7226/jtfm.21.2.65.

Purnomo, H., Suyamto, D., Abdullah, L., \& Irawati, R. H. (2012). REDD+ actor analysis and political mapping: an Indonesian case study. International Forestry Review, 14(1), 74-89. http://doi.org/10.1505/146554812799973208.

Rahman, M. S., \& Giessen, L. (2014). Mapping international forest-related issues and main actors' positions in Bangladesh 1. International Forestry Review, 16(6), 586-601.

Resosudarmo, B.P., Ardiansyah, F., \& Napitupulu, L., (2013). The dynamics of climate change governance in Indonesia. In: Held, D., Roger, C., Nag, E.M. (Eds.), Climate Governance in the Developing World. Polity, Cambridge, pp. 73-90.

Rietig, K. (2014). Reinforcement of multilevel governance dynamics: creating momentum for increasing ambitions in international climate negotiations. International Environmental Agreements: Politics, Law and Economics, 14(4), 371-389.

Rochmayanto, Y. (2013). Analisis resiko kegagalan implementasi REDD+ di provinsi Riau. Jurnal Analisis Kebijakan Kehutanan, 10(2), 149-165.

Sahide, M. A. K., Nurrochmat, D. R., \& Giessen, L. (2015a). The regime complex for tropical rainforest transformation: Analysing the relevance of multiple global and regional land use regimes in Indonesia. Land Use Policy,47, 408-425. 
Sahide, M.A.K., Wibowo, A., Burns, S.L., \& Giessen, L. (2015b). Reclaiming state authority over agricultural certification: from voluntary private to mandatory state regimes on palm oil in Indonesia. Food Policy, under review.

Santosa, M.A., Khatarina, J., \& Suwana, A.S. (2013). The progress on governing REDD+ in Indonesia [Special edition]. International Journal of Rural and Law Policy, http://epress.lib. uts.edu.au/journals/index.php/ijrlp/article/view/3356. [Accessed 18 December 2014].

Simangunsong, B.C.H. (2004). The economic performance of Indonesia's forest sector in the period 1980-2002. Briefing Paper No. 4. Departemen Kehutanan Indonesia.

Simon, H. A. (1981). Entscheidungsverhalten in Organisationen: Eine Untersuchung von Entscheidungsprozessen in Management und Verwaltung. 3. Aufl. Landsberg/Lech: Verlag Moderne Industrie.

Steffek J. (2009). Discursive legitimation in environmental governance. Forest Policy and Economics 11(5):313-318. http://dx.doi.org/10.1016/j.forpol.2009.04.003.

Sulistiawati, L.Y. (2013). REDD+ Issues Influence in Indonesia's Regulatory Process Case Studies UNREDD Indonesia, REDD Plus Project Indonesia-Norway. PhD Thesis. University of Washington.

Tallontire, A., \& Blowfield, M. E. (2000). Will the WTO prevent the growth of ethical trade? Implications of potential changes to WTO rules for environmental and social standards in the forest sector. Journal of International Development, 12(4), 571-584.

The Government of the Kingdom of Norway \&The Government of the Republic of Indonesia. (2010). Letter of Intent between the Government of the Kingdom of Norway and the Government of the Republic of Indonesia on "Cooperation on reducing greenhouse gas emissions from deforestation and forest degradation" https://www.regjeringen.no/globalassets/upload/smk/ vedlegg/2010/indonesiaavtale.pdf. [Accessed 18 December 2014].

The Jakarta Post. 2014. APKI wants more access to local market. http://m.thejakartapost.com/news/ 2014/07/19/apki-wants-more-access-localmarket.html. [Accessed 18 December 2014].

Tuppura, A., Toppinen, A., \& Puumalainen, K. (2015). Forest certification and ISO 14001: Current state and motivation in forest companies. Business Strategy and the Environment.

Ulybina, O., \& Fennell, S. (2013). Forest certification in Russia: Challenges of institutional development. Ecological Economics, 95, 178-187.

Underdal, A. (1992). The Concept of RegimeEffectiveness'. Cooperation and conflict, 27(3), 227-240.

Underdal, A. (2002). One question, two answers. Environmental regime effectiveness: Confronting theory with evidence, 3-45.

UNECE (United Nations. Economic Commission for Europe) \& FAO (Food and Agriculture Organization. (2013). Forest Products Annual Market Review, 2012-2013. New York and Geneva, United Nations, Geneva Timber and Forest Study Paper, 33.

Van Schaik, L., \& Schunz, S. (2012). Explaining EU Activism and Impact in Global Climate Politics: Is the Union a Norm-or Interest-Driven Actor?. JCMS: Journal of Common Market Studies, 50(1), 169-186.

Walter, M. (2006, updated 2008). Analysis of the FSC and PEFC Systems for forest Management certification using the Forest Certification Assessment Guide. http://assets.panda.org/downloads/ 20081117 final fcag assessment.pdf. [Accessed 17 April 2015].

Walter, M. (2011). Analysis of the PEFC system for forest management certification using the forest certification assessment guide (FCAG). http://awsassets.panda.org/downloads/ 2011_03_20_mwalter_fcag_analysis_pefc.pdf. [Accessed 12 June 2015].

Weber, M. (2010). Die protestantische Ethik und der Geist des Kapitalismus. CH Beck.

Wibowo, A., \& Giessen, L. (2015a). Actor positions on primary and secondary international forestrelated issues relevant in Indonesia. Journal of Sustainable Development, 8(3), 10-27. http://doi.org/10.5539/jsd.v8n3p10.

Wibowo, A., \& Giessen, L. (2015b). Absolute and relative power gains among state agencies in forestrelated land use politics: The Ministry of Forestry and its competitors in the REDD+ Programme and the One Map Policy in Indonesia. Land Use Policy, 49, 131-141.

Wibowo, A., Sahide, M.A.K, \& Giessen, L. (2015a). From voluntary private to mandatory state governance in Indonesian forest certification: Reclaiming authority and legitimacy by bureaucracies. Article submitted to Global Environmental Change. 
Wibowo, A., Pratiwi, S., \& Giessen, L. (2015b). Comparing forest certification and timber legality systems in Indonesia: Complementary or competitive?. Environmental, Development and Sustainability, under revision.

Wibowo, A., Sahide, M.A.K, \& Giessen, L. (2015c). The role of the Ministry of Forestry in internationalizing domestic forest policy in Indonesia. Unpublished paper. University of Göttingen. Germany.

Wibowo, A., Sahide, M.A.K., Dharmawan, B., Pratiwi, S., \& Giessen L. (2015d). Ragam skema sertifikasi hutan global dan opsi transformasinya di Indonesia. Risalah Kebijakan Pertanian dan Lingkungan, 2(1), 1-8.

Wiersum, K. F., \& Elands, B. H. (2013). Opinions on legality principles considered in the FLEGT/VPA policy in Ghana and Indonesia. Forest policy and economics, 32, 14-22.

Wijaya, I. M., Rosyidie, A., \& Onimaru, T. (2012). The implementation of mandatory forest certification: A case study on forest concession in Indonesia. Jurnal Perencanaan Wilayah dan Kota, 2(3), 655-666.

Wilson, J. (2003). Internationalization'and the conservation of Canada's boreal ecosystems. CanadianAmerican Public Policy, (56), 1.

WWF (World Wide Fund for Nature) \& WB (World Bank). (2006, July). Forest Certification Assessment Guide (FCAG): A Framework for Assessing Credible Forest Certification Systems/Schemes. WWF/World Bank Global Forest Alliance. http://siteresources.worldbank.org/ EXTFORESTS/Resources/FCAG_WB_English.pdf. [Accessed 11 May 2015]. 


\section{Constitutive Publications}

1. Wibowo, A., \& Giessen, L. (2015). Actor positions on primary and secondary international forestrelated issues relevant in Indonesia. Journal of Sustainable Development, 8(3):10-27.

2. Wibowo, A., \& Giessen, L. (2015). Absolute and relative power gains among state agencies in forest-related land use politics: The Ministry of Forestry and its competitors in the REDD+ Programme and the One Map Policy in Indonesia. Land Use Policy, 49, 131-141.

3. Wibowo, A., Sahide, M.AK, \& Giessen, L. (2015). From voluntary private to mandatory state governance in Indonesian forest certification: Reclaiming authority and legitimacy by bureaucracies. Article submitted to Global Environmental Change.

4. Pratiwi, S., Wibowo, A., \& Giessen, L. (2015). Third-party certification of forest management in Indonesia: Analysing stakeholders' recognition and preferences. Jurnal Manajemen Hutan Tropika [Journal of Tropical Forest Management], 21(2), 65-75.

5. Wibowo, A., Pratiwi, S., \& Giessen, L. (2015). Comparing forest certification and timber legality systems in Indonesia: Complementary or competitive? Environmental, Development and Sustainability, under revision. 


\title{
Actor Positions on Primary and Secondary International Forest-related Issues Relevant in Indonesia
}

\author{
Agung Wibowo ${ }^{1,2} \&$ Lukas Giessen ${ }^{2}$ \\ ${ }^{1}$ Department of Forestry, Faculty of Agriculture, University of Palangka Raya, Indonesia \\ ${ }^{2}$ Chair of Forest and Nature Conservation Policy, University of Goettingen, Germany \\ Correspondence: Agung Wibowo, Chair of Forest and Nature Conservation Policy, University of Goettingen, \\ Buesgenweg 3, 37077 Goettingen, Germany. Tel: 49-55-1391-3391. \\ E-mail: agung.wibowo@stud.uni-goettingen.de
}

Received: February 26, 2015 Accepted: March 10, 2015 Online Published: April 15, 2015

doi:10.5539/jsd.v8n3p10 URL: http://dx.doi.org/10.5539/jsd.v8n3p10

\begin{abstract}
Over the last 20 years a considerable number of international forest-related policies has evolved, collectively referred to as the international forest regime complex. The objectives of this study are to identify the most relevant international forest-related issues discussed in Indonesia as well as the most active actors and their positions on these issues. The empirical methods used include content analysis of Indonesian newspapers, national expert journals, expert mailing lists, and international organizations' position papers. In addition, experts were interviewed to verify and complement the data. As a result, three primary forest-related international issues in Indonesia are identified, namely: timber legality; climate change including REDD initiative; and oil palm plantation and its environmental aspects; and the other four considered as secondary issues, namely: harmonization of wood and forest certification schemes; land use change; forest and species conservation; and deforestation and decentralized forest governance. Public and expert deliberations are found to differ regarding the depth of information as well as their immediate importance for the people and their long-term objectives. The Ministry of Forestry and, surprisingly, the Ministry of Trade are the most active actors in these issues. The main lines of conflict lie between forest utilization interests which are supported by the Ministry of Forestry, Ministry of Trade, oil palm and wood industry associations face-to-face with forest conservation interests powered by WWF and Greenpeace.
\end{abstract}

Keywords: international issues, forest policy, international forest regime complex, Indonesia

\section{Introduction}

Recent forest governance presents in many arena has involved more actors spreading from state representatives, intergovernmental organizations, treaty secretariats, multilateral financial institutions, nongovernmental organizations, as well as business and industry groups (Chasek et al., 2014) and assembling transnational interests into a unique forest regime (Overdevest \& Zeitlin, 2014a; 2014b). Krasner (1982) defines international regimes as "a set of implicit or explicit principles, norms, rules, and decision-making procedures around which actors' expectations converge in a given area of international relations." Simply put and applied to the field of forest policy, this theory describes and analyses international cooperation, primarily among states, and how internationally agreed principles, norms and rules become relevant in national contexts (Smouts, 2008). International regimes are designed in order to influence state behavior including their implementation through national action and policies (Bernstein \& Cashore, 2012; Giessen, 2012; Giessen et al., 2014). However, every country does not necessarily have equal influence in the arena of international diplomacy when advancing its interest, and eventually politically weak countries have to accept unsatisfactory international agreements (Lindstad \& Solberg, 2010). A basic question, however, remains: are international commitments made relevant, implemented and enforced in individual countries? And how are specific issues of the international forest regimes complex (IFRC) put on the political agenda in public and expert networks and their deliberations.

Humphreys (2006) identifies an international forest regime complex (IFRC) which consists of the following elements: forests as a carbon sink under the United Nations Framework Convention on Climate Change (UNFCCC) regime; protection of endangered species under the Convention on International Trade in Endangered Species of Wild Fauna and Flora (CITES) regime; concerning indigenous and tribal people under 
the regime of ILO Convention No. 169; sustainable forest management issues under the United Nations Forum on Forest (UNFF) regime; trade liberalization of forest products under the World Trade Organization (WTO) and General Agreement on Tariffs and Trade (GATT) regime; land management issue under the Convention to Combat Desertification (CCD) regime; conservation of forest biodiversity as an issue under the Convention on Biological Diversity (CBD) regime and the International Union for Conservation of Nature (IUCN) regime; and chain of custody rules under the private Forest Stewardship Council (FSC) regime.

Each of these forest-related regimes has not necessarily been established simultaneously in all countries signatory to the respective agreements. The Global Forest Expert Panel on the International Forest Regime mentions a number of regimes influencing forest-related policy in several countries (Rayner et al., 2010; similar McDermott et al., 2010a; 2010b). Indonesia, the third-largest tropical rainforest country and the largest tropical lumber producer (UN-REDD, 2012; ITTO, 2011) is also influenced by diverse interests in its forests (Nurrochmat, 2005; Maryudi et al., 2012; Brockhaus et al., 2012). Identification of the major domestic political issues related to international forest policies, the actors involved and their positions are then crucial to understand the actual implementation of the IFRC and its specific components in Indonesia (Note 1).

Based on circumstance, the objectives of this article are to identify the most relevant international forest-related issues discussed in Indonesian public and expert deliberations, and to identify the most active actors in these deliberations and their positions on the issues noted. In doing so, the authors are able to identify which parts of the international forest regime complex (IFRC) are currently the most relevant in Indonesia and which actors might have an interest in creating the ways in which the IFRC is implemented in Indonesia.

\section{Theoretical Approach}

"Actor" in this study refers to an individual person, governmental or non-governmental organization with a stake in any forest-related policy. Actors have their own interests which are not always precisely displayed in public arena (Krott, 2005). Public bureaucracies (e.g. a ministry) have dual goals: they strive for public service according to their mandates and are pursuing informal organizational goals. Due to these goals, public bureaucracies compete for resources, political domains and influence (Peters, 2010). To reach their goals successfully, actors seek other actors with (rather) similar interest, set up coalitions, raise bargaining positions and gain power. In this context, mass media could be used as a channel to send signals of preference and positions to other actors.

Issue is a specific problem and could be a starting point of a forest policy process (Sadath \& Krott, 2012). Issue arises because actors succeed in getting their goals onto the political agenda. They are rooted in conflictual underlying interests of the actors and manifest in public or semipublic deliberations of actors. An issue may come from within or beyond the country, depending on its scope and urgency. In this study, an international issue relevant in Indonesia means a specific issue comes from both national and international levels, and it has goals, measures, assumed effect, implementing actors and related to the global agenda on forest in Indonesia. An issue brought by powerful actor has a big opportunity to go into agenda setting, policy formulation then convert into government policy (Howlett \& Ramesh, 1995). Accordingly, issue and actor cannot be separated. Ojha et al. (2009) suggest redistributing cultural/ideological power to actors with less power in order to raise the quality of deliberations.

Steffek (2009) identifies five groups involved in influencing policy making, viz.: representatives of the state, independent experts, activists and lobbyists, journalists and citizens. Each has diverse power in policy making process. Yet, their voices could be even louder if sounding through mass media. Contrarily, the goals which are only delivered in actors' private spheres will fail in showing real political orientation, especially to the public (Krott, 2005). According to this, any statement from actors through mass media can be seen as their initial positions in a specific issue recorded by public. An actor's statement in expert deliberations draws more concrete position of the actor and less bias although, due to their hidden agenda, it may differ from which was published in public mass media.

The Method section describes in detail how the study was conducted, including conceptual and operational definitions of the variables used in the study, Different types of studies will rely on different methodologies; however, a complete description of the methods used enables the reader to evaluate the appropriateness of your methods and the reliability and the validity of your results, It also permits experienced investigators to replicate the study, If your manuscript is an update of an ongoing or earlier study and the method has been published in detail elsewhere, you may refer the reader to that source and simply give a brief synopsis of the method in this section. 


\section{Methodology}

In order to map the international forest related issues in Indonesia, this research distinguishes between deliberations of actors made either in public, such as newspapers, or in a more limited quasi-public arena, such as in expert media. Both differ regarding their degree of publicity and hence can be used differently by actors, e.g. by mobilizing the general public or by discussing detailed issues in expert circles as a selected audience. The authors consider articles/information published by these sources of data within publication period of 2008 and 2012. The public deliberation is derived from magazines and newspapers easily accessible to a wide public audience. For analyzing public deliberations, the authors take two steps. First, choose two national newspapers in the Indonesian language, viz. Media Indonesia and Kompas, and a national newspaper in English, namely The Jakarta Post (Note 2). The combination of keywords hutan ("forest"), kayu ("wood"), internasional ("international") and global were inserted on each newspaper's search engine to elicit 200 first set of relevant articles in order to identify relevant international issues within Indonesian public deliberation. The determination of relevance of an article depended upon the connection of its content with international forest-related issues in Indonesia.

Second, based on identified keywords in the first step, the Google search engine was employed to find more relevant and concrete articles and comments. As an example, when an article in the selected newspapers talks about timber legality, it actually discusses SVLK (Sistem Verifikasi Legalitas Kayu), FLEGT (Forest Law Enforcement, Governance and Trade) and VPAs (Voluntary Partnership Agreements) implementation and the debates around it. The authors then put SVLK, FLEGT and VPA into Google to collect a wider discussion. Only articles from public mass media were considered in order to map the public deliberation on a given issue.

To explore the expert deliberations on international forest-related issues in Indonesia the authors collected data from four sources.

First, interviewed experts whose deeper knowledge on forestry-related issues and international policy influences on Indonesian forestry policies respondents included senior lecturers from Bogor Agricultural University (IPB) and Gadjah Mada University (UGM) (each one person); senior advisor of the World Bank in Jakarta; senior advisor of the Ministry of Forestry; high official at the Ministry of Forestry; administrator Indonesian forester mailing list; editor at Indonesian forestry journal, and Minister of Forestry. Interview is required as supplementary method to verify specific data from other sources and was used to distinguish between primary issues of political relevance and the secondary ones. Interviewees were selected based on quick and ease of field access. To each of them, the authors posed two questions: (1) what are the rules/agreements/policies/issues at the international level that are currently relevant for forest, forestry or forest-related policy making in Indonesia? (2) How are these issues relevant in Indonesia?

Second, data from professional journals in the fields of forestry, agriculture and conservation were collected to catch the discussion circulating among these experts' networks. These journals are Majalah Kehutanan Indonesia, Tabloid Agro Indonesia and Mongabai (Note 3). Majalah Kehutanan Indonesia (Indonesian Forestry Magazine) is a monthly magazine published by the Ministry of Forestry. All articles it contained from 2008 to 2011 were examined and only those with international pertinence to be considered. Agro Indonesia is a weekly tabloid, published since June 2004 and widely read by practitioners and policy analysts in the fields of forestry, agriculture, fishery, plantations and husbandry. All relevant topics from February 2009 (the first online edition) to October 2012 were screened.

Third, the discussions among academics, observers and practitioners on the Indonesian forester interactive mailing list (rimbawan-interaktif@yahoogroups.com) were also taken into account. This mailing list was founded in 2000 and had 1406 members as of September 2014. The authors only considered entries within years 2010 until 2014.

Fourth, any publications from international organizations related to the Indonesian forest sector such as Food and Agriculture Organization (FAO) and International Tropical Timber Organization (ITTO) files were also studied.

Based on the data from all sources (interviews, professional journals, environmental and conservation news sites, mailing list archives and international publications), the specific issues were identified. Selected issues may partly overlap in categorization due to difference context or focus of deliberations. From the public and expert data sources, the authors elicited and interpreted the main actors' positions on the issue if applicable. The absence of any relevant news in public media indicating the issue was not important for public or had not become a public concern. 


\section{Results}

By scrutinizing source of data above, the authors identify seven primary and secondary issues on international policies relevant to forests in Indonesia. The primary issues are: timber legality, oil palm plantation and its environmental aspects, and climate change including REDD initiative; while the secondary issues consist of harmonization of wood and forest certification schemes, land use change, forest and species conservation, and deforestation and decentralized forest governance (Appendix A). Detailed descriptions for each issue follow below, distinguishing between public and expert deliberations and summarizing the positions taken by the main actors in each issue.

\subsection{Primary International Forest-related Issues}

\subsubsection{Timber Legality}

Forest Law Enforcement, Governance and Trade (FLEGT) is the European Union (EU) policy to combat illegal logging and illegal trade in forest products. This includes the adoption of the FLEGT Action Plan (2003) which contains EU's commitment to develop a Voluntary Partnership Agreement (VPA) with timber producing countries to prevent illegal timber products from entering the European market. On 4 May 2011, the Indonesian Minister of Forestry and the EU Trade Commissioner signed the FLEGT document. Through this agreement, the EU will ensure free and unrestricted access to all FLEGT-licensed timber products from Indonesia. In order to implement the agreement, the Indonesian government developed the Timber Legality Verification System (Sistem Verifikasi Legalitas Kayu or SVLK). It is up to the EU now to recognize SVLK as a tool to determine the legality of Indonesian timber products exported to the EU.

Public deliberation

The agreement lists 48 kinds of certified wood products under that SVLK scheme that may be imported without restriction into EU countries (Media Indonesia, 2011a; Harian Terbit, 2012a). The government stated that this policy was fully supported by the industry. According to the Director of Processing and Marketing of Forest Products of the MoF, by the end of 2011 there were about 125 timber companies implementing SVLK along with 30 forest concessionaires and timber estates. An industrial group represented by Director of Riau Andalan Pulp and Paper said they supported the government's efforts to encourage timber legality verification standards to be recognized internationally (Media Indonesia, 2011a; 2011b). At the SVLK launching event, the Minister of Forestry also claimed SVLK would prevent timber laundering in other countries (Kompas, 2012a). Hence, the government expects the program would be supported by small and medium scale enterprises (SMEs). For that purpose government allocated IDR 3 billion in financial assistance for handicraft producers in Bali and furniture makers in Jepara (The Jakarta Post, 2012a). The government committed to implementing SVLK for forest unit management and processing industries in December 2012 and 2013 respectively, and rejected a proposal from the APHI (Asosiasi Pengusaha Hutan Indonesia or Association of Indonesian Forest Concessionaires) and Asmindo (Asosiasi Industri Permebelan dan Kerajinan Indonesia or Indonesian Furniture Industry and Handicraft Association) to delay (Harian Terbit, 2012b; Suara Merdeka, 2012). However, later on, the EU was still reviewing SVLK rules and not yet ready to sign the agreement as of November 2012 (The Jakarta Post, 2012b). Regarding this point, Deputy Minister of Trade said he questioned the readiness of the EU to implement wood export rules, and even bring this case to WTO if they found evidence of unfair trade (Antara, 2012a).

\section{Expert deliberation}

Using SVLK as the sole governmental tool for determining timber legality and applied to all kinds of wood-based products is actually not fully supported by industry groups. The chairman of Asmindo refused enactment of SVLK for furniture products since their raw materials are derived from primary industries that hold legality certificates (Agro Indonesia, 2012a). By contrast, Minister of Forestry felt confident that SVLK was the answer to the Indonesian timber trade's problems and he asked all wood industries to meet it (Majalah Kehutanan Indonesia, 2011a; 2011b). On the other hand, the Conservation Director at WWF Indonesia said that $50 \%$ of consumers in the country ask about wood products legality when they buy it (Agro Indonesia, 2012b).

The third suspension of VPA signing by the EU raised questions. The Chair of the Indonesian Delegation for VPA Negotiation argues that VPA looks like a non-tariff barrier to trade (Agro Indonesia, 2012c). The Director of Forest Production Development and Forest Products Marketing of the MoF also doubted the EU's commitment to reducing illegal logging since the reason for postponement was an administrative matter, namely translating the documents into the 27 languages of EU member countries (Agro Indonesia, 2012d). Furthermore, analysts blamed the severe economic crisis in some EU countries and industry protectionism as the real reasons for SVLK delay (Rimbawan Interaktif, 2012a). Researchers criticised the VPA as disguised trade barriers to 
obstruct Indonesian wood products, especially for pulp and paper. Similarly, the Director of the Forestry Multistakeholder Programme also condemned the EU's postponement of VPA endorsement (Agro Indonesia, 2012c).

In response to the VPA and SVLK controversies, a lecturer at IPB said that the issue was not about legality but legitimacy (Agro Indonesia, 2012e). Other experts and practitioners were still debating whether SVLK had to be implemented, since approximately $40 \%$ of sawmills are illegal and this would affect the legality of wood products (Rimbawan Interaktif, 2012b). They then asked the government to place more emphasis on bilateral agreements rather than waiting for EU agreement on SVLK, since they said EU regulation is not legally binding for its members (Rimbawan Interaktif, 2012c).

There are six groups involved in the timber legality issue, namely the Ministries of Forestry and the Ministry of Trade; primary and large-scale forest industries; Asmindo, APHI and the downstream industries; the European Union (EU); the World Wide Fund for Nature (WWF); and researchers and academics. The government, large-scale companies, environmental groups and the EU support a wood certification programme in order to achieve sustainable forest management. Meanwhile, Asmindo and APHI consider certification for furniture and handicrafts unnecessary because the raw materials they use are legal, and certification would increase production cost and lead to a decline in competitiveness. On the other hand, academics suggested all parties seek the legitimacy of Indonesian timber products with the assurance of forest sustainability.

\subsubsection{Climate Change Including REDD Initiative}

Reducing Emissions from Deforestation and Forest Degradation (REDD) was an approach proposed at Climate Change Conference 13 in Bali in 2007 and amended in 2009 at the Copenhagen Climate Change Summit. It contains mechanisms for REDD and forest-rich countries to earn compensation for preserving their forests. President Yudhoyono, at the G20 Summit in Pittsburgh, filed a voluntary commitment to reduce Indonesia's carbon emissions by $26 \%$ by 2020 , up to $41 \%$ with international assistance. Following the commitment, the government set up 70 programs funded by the state budget to reduce emissions as promised.

\section{Public deliberation}

Climate change has attracted people's attention successfully. The emergence of the REDD initiative, however, raises a lot of pros and cons. Indigenous environmental groups reject REDD and call it "colonialism of forests". They argue that REDD scheme will only seize control of indigenous forest people's land and allow capital owners to occupy it (Kompas, 2009). At provincial level, some governors felt their provinces were appropriate for REDD implementation. Nevertheless, at that time the central government designated only eight provinces for the REDD trial (Kompas, 2011a). In the practice, each stage of REDD implementation program involved many parties and this led to slow progress. Many are worried, since the program was launched and approved internationally (Kompas, 2011b)

Expert deliberation

The Indonesian commitment to reduce carbon emissions concerned the involvement of the Norwegian government. In May 2010, Indonesia and Norway signed a Letter of Intent (LoI) with USD 1 billion of REDD+ funding for emission reduction activities (Majalah Kehutanan Indonesia, 2010). In 2011 the Ministry of Forestry also received a grant of USD 3.6 million from the Forest Carbon Partnership Facility to support Indonesia in reducing greenhouse gas emission by $26 \%$ by 2020 (Majalah Kehutanan Indonesia, 2011c). To meet its commitment the Indonesian government's REDD+ Task Force has done many things, including a logging moratorium on 64 million hectares of primary forests and peatlands and limiting plantation size area (Agro Indonesia, 2011c; 2012i). However, Norway said the effort was not enough and Indonesia must do more (Agro Indonesia, 2012j). Lately, Norway would like to resign from the LoI (Rimbawan Interaktif, 2012e).

Regarding this issue the authors consider there are three most active actors who affecting Indonesia policies, namely the Presidential Delivery Unit for Development Monitoring and Oversight (UKP4) which also leads REDD+ Task Force, the Ministry of Forestry, and scientists. UKP4 has set many policies related to forest utilization and national strategic for REDD implementation. Those policies have wide implications for all REDD activities throughout Indonesia. Meanwhile, the Ministry of Forestry as a technical actor has an important role since forest sector is expected to reduce emission by $14 \%$ of the total national target. Their performance would be significant contribution to the success of REDD implementation. Scientists have much influence through academic discussion and policy formulation.

\subsubsection{Oil Palm Plantation and Its Environmental Aspects}

Indonesia had the biggest area of oil palm plantation with 48\% of world palm oil production in 2012 (Note 4) 
(Majalah Swa, 2012). This status was achieved in 2007 after Indonesian palm oil production exceeded that of Malaysia. At $34 \%$, palm oil has the largest market share compared to other vegetable oils. Palm oil gradually shifted the market share of soybean oil produced by subtropical countries, which only reaches $30.1 \%$ (Media Indonesia, 2010a).

Public deliberation

The high productivity of oil palm plantation which takes around six to ten times compared to other vegetable oils' grown in Europe and the US has been triggering unfair competition among its competitors. The Secretary General of Indonesian Palm Oil Association (Gabungan Pengusaha Kelapa Sawit Indonesia or GAPKI) said that the pressure on the oil has been going on since early 1980s. He detailed that NGOs' allegations ranging from claim that palm oil having high cholesterol, inducing heart disease, causing pollution and destroying orangutan habitats (Media Indonesia, 2010b). The Indonesian government considered that claims of environmental destruction against the Indonesian oil palm plantation as a part of a trade war, which was to be countered by providing more accurate information. The Coordinator Minister for Economic Affairs said the government and industry had to fight against a smear campaign related to palm oil, even bringing unfair trade practices allegations to the World Trade Organization or to bilateral meetings (The Jakarta Post, 2012c). Previously, in 2011, GAPKI resigned from the Roundtable on Sustainable Palm Oil (RSPO) and supported Indonesian Sustainable Palm Oil (ISPO) as an alternative framework standard for palm oil certification, though still allowing their members to stay in RSPO (Bisnis Indonesia, 2011; Republika Online, 2011a). At the APEC CEO Summit 2012 in Vladivostok, a number of developed countries, led by the US, did not approve palm oil as environmental goods. At the time, President Yudhoyono said that palm oil was an environmentally friendly product, but it was blocked by unfair competition (Suara Pembaruan, 2012). In November 2012, Greenpeace indicated Indonesian oil palm companies did not protect the environment, since they did not hold RSPO certificates and were planting in shallow peat land, which however is legal in Indonesia (Antara, 2012b).

\section{Expert deliberation}

Oil Palm plantation issue in the Ministry of Forestry focused more on licensing forestland for plantation and mining. Hence, MoF did not pay much attention to this issue. Conflicts between Indonesian palm oil producers and other vegetable oil producers from Europe and the US have been going more intense and are recognized by Indonesian government as well as GAPKI. The Indonesian Deputy Minister of Trade challenged the EU to conduct research and prove their claim that oil palm destroys the environment and is harmful to health. He even presented scientific data to refute all such claims (Agro Indonesia, 2011a). In addition, the Indonesian government is also awaiting the US response on charges that palm oil did not meet the minimum standard of greenhouse gas emissions reduction (Agro Indonesia, 2012h). This unpleasant business attitude convinced GAPKI to resign from RSPO, since RSPO tends to support consumers' interests. RSPO membership consists $30 \%$ of growers and 70\% of non-growers, while RSPO decisions are based on a majority voice. GAPKI considered RSPO rules as only complicating matters for producers, and consumers did not buy palm oil with RSPO certificates at premium prices (Agro Indonesia, 2011b). GAPKI also suspects RSPO directed non-governmental organizations to protect western countries' interests since they bluntly call for open war against palm oil. Apparently, this conflict would take a long time since President Yudhoyono fully supports expanding oil palm plantations (Investor Daily Indonesia, 2012).

In general, groups involved in palm oil issue polarized into producer and non-producer. Group of producer consists of the Ministries of Forestry, Ministry of Trade, large-scale oil palm companies and their association (GAPKI); while the non-producer group comprises the EU, the USA, and environmental NGOs, to wit WWF and Greenpeace. Surprisingly, buyers' alignment was determined by the groups' campaign through mass media. Although buyers, being rational, like qualitied products at low prices, they do not want to be accused as a group who degrades the environment.

\subsection{Secondary International Forest-related Issues}

\subsubsection{Harmonization of Wood and Forest Certification Schemes}

Issue on timber and forest certification emerged from the need for an information system to assess whether a timber product has been processed through environmentally friendly ways. For this purpose, environmental activists and other groups set up the Forest Stewardship Council (FSC) certification scheme in 1993. By this time, there also emerged other certification schemes such as the Programme for the Endorsement of Forest Certification (PEFC) in Europe, Sustainable Forestry Initiative (SFI) in North America and Lembaga Ekolabel Indonesia (LEI) in Indonesia. All of them are voluntary, which means participants could adopt the standards if they are willing and fulfill the requirements. In 2009, the Indonesian government developed SVLK as a timber 
legality assurance and applied it in 2013 to all wood-based industries. Each certification scheme has specific attributes, such as market acceptance, cost, length of certification process, emphasized aspects, as well as standards flexibility. Business units, however, constantly use economic considerations in choosing affordable schemes in line with profit maximization. For this reason, some of them took more than one certification scheme at once (Bisnis Indonesia, 2012). This leads to a double charge, whereas buyers do not require a specific certification model. There was no any valuable public deliberation to this issue. Conversely, five of seven experts interviewed unequivocally stated that forest and timber certification was an international issue that strongly influenced Indonesian forest policy and practices.

\section{Expert deliberation}

As a matter of fact, the FSC scheme is voluntary and has been adopted by industries that primarily export wood-based products to Europe. Regarding this point, the Deputy Minister of Trade stated that there should be a bridge between mandatory and voluntary schemes so that those who receive SVLK automatically become FSC certified (Agro Indonesia, 2012f). A similar idea was also conveyed by the Executive Director of APHI, since the government was to do so on a voluntary basis (Agro Indonesia, 2012g). Along with the talks, on 6 March 2012, the Indonesia Forestry Certification Coordination (IFFC) introduced the PEFC certification scheme, which is known to have weak environmental criteria compared to the FSC, but was received well in Europe and the US. At present, the issue on harmonization of certification schemes is still on going.

Based on previous information, there are four groups with strong interest in this issue, namely the Ministries of Forestry and Trade; the Indonesian timber industry; the WWF; and certification scheme owners. The Indonesian government must fight for wood products to be accepted in overseas markets. Therefore, trade barriers must be removed, and agreement with buyer countries have to be signed as soon as possible. Meantime, logging companies and other large-scale wood-based industries want their products accepted by the market with or without certification. Nevertheless, the furniture and handicraft industries reject double certification because their raw materials have already been certified, so they expect their products to be certified automatically. And last, certification scheme owners also want to preserve their certification schemes.

\subsubsection{Land Use Change}

Land use change in Indonesia is a warm issue among industrial groups and environmental activists. This comes from the USD 1 billion Letter of Intent (LoI) between Indonesia and Norway that includes moratorium of new forest utilization permits as Indonesian commitment to reduce carbon emissions. As known, the Oslo Agreement on forest moratorium actually applies only to primary forests and peat lands, and effectively began in early 2011 . However, foreign NGOs tried to pressure the government to implement the moratorium on all types of forest, including secondary forests, which then were opposed by palm producers. In this issue, there is no any meaningful debate arising in public media.

\section{Expert deliberation}

The Chairperson of Indonesian Enterprises Association (Apindo) said that the President had to prioritize national interests rather than satisfy foreign insistence to implement the moratorium on all type of forests. The Association of Indonesian Palm Oil (GAPKI) stated that the moratorium on oil palm development and expansion was not possible since this commodity delivered considerable economic and social benefits (Agro Indonesia, 2010). In May 2011, President Yudhoyono issued Presidential Decree No. 10, delaying all new utilization permits within primary forest and peat lands for two years, and instructed the Minister of Forestry to improve forest management policies (Majalah Kehutanan Indonesia, 2011d). However, the Secretary-General of the Ministry of Forestry and Greenpeace both said that the moratorium had to expand beyond two years (Mongabai Indonesia, 2012b). On the other hand, the Indigenous Peoples' Alliance of the Archipelago (AMAN) took this opportunity to have included 6 million hectares of customary land into the New Integrated National Map (Mongabai Indonesia, 2012c). Some experts argue that the government should commit to a moratorium in all of primary forest and peat land area in order to meet the presidential pledge to reduce carbon emission by $26 \%$ in 2020. They also ask the government to increase palm oil production through intensification rather than extensification (Rimbawan Interaktif, 2012d).

Based on these findings, there are five groups strongly involved in this issue. First, the Ministry of Forestry as the authority in control of forestland use; second, plantation companies and other business groups who need vast land resources to running their business; third, indigenous people's groups concerned with keeping their land from encroachment by industry. Environmental organizations such as Greenpeace also pay attention to the land-use change issue to make sure the forest moratorium is implemented properly. Lastly, scientists raise the government's awareness of how to balance both economic growth and forest and environmental sustainability. 


\subsubsection{Forest and Species Conservation}

Forest degradation and deforestation caused by fires, improper land use and logging activities have deflated biodiversity in Indonesia and lead to some species being endangered or extinct. The Indonesian government, people and communities in and around forests, business groups and conservation organizations then put much effort to prevent its deterioration.

Public deliberation

There were not so many articles on forest, land and species conservation in public mass media. If any, they put more emphasis on conflicts of interest in the conservation field, not conservation activities themselves. Conservation activities were undertaken to protect nature and build livelihood. For example, a breeding center for the endangered Bali starling was launched by Begawan Foundation in Bali (The Jakarta Post, 2011). They bred local birds with others to enhance genetic diversity. In Lampung, the Artha Graha Network in cooperation with the Ministry of Forestry conserve forest for tigers, elephants, gibbons and other wildlife (Media Indonesia, 2011c). Other groups take indirect activities to conserve nature, such as the Indonesian Wild Birds Reservation, which launched a postage stamp series featuring endangered Indonesian birds (The Jakarta Post, 2012d). At the international level, the United States erased USD 28.5 million of Indonesian debt in a debt-for-nature swap agreement, namely the transfer of debt used for forest conservation. Previously, the US government wrote off USD 19.6 million of Indonesian debt for forest conservation focusing on the 13 national parks on Sumatra (Republika Online, 2011b).

\section{Expert deliberation}

The Ministry of Forestry has agencies for conserving nature under the supervision of the Directorate General of Forest Preservation and Natural Conservation. They are very concerned about endangered species such as Sunda pangolin (Manis javanica), Badak Jawa (Rhinoceros sondaicus), and Elang Jawa (Spizaetus bartelsi) in Java; Badak Sumatra (Dicerorhinus sumatrensis) in Sumatra; Cendana (Santalum album) in East Nusa Tenggara; snake-necked turtle (Chelodina mccordi) in Rote Island and tiger and orchid species (Majalah Kehutanan Indonesia, 2008; 2009a; 2009b; 2009c; also Mongabai Indonesia, 2012a). Most articles about species conservation were linked to the species status according to the International Union for Conservation of Nature (IUCN) or CITES (the Convention on International Trade in Endangered Species of Wild Fauna and Flora). On the Indonesian forester mailing list, the discussions about conservation circulate around the forest as the habitat of animals and plants and the function of forests in mitigating natural disaster. Discussion also arose when mass media revealed violations committed by companies, such as the poaching of orangutans (Pongo pygmaeus) when opening oil palm plantations (Rimbawan Interaktif, 2012f; 2012g).

Only three actors with two meaningful roles were present in this issue, namely the Ministry of Forestry versus forest companies and conservation organizations. Mass media consider their activities important for arousing public awareness in environmental protection. Although environmental organizations and scientists talk about this issue, their roles were not very noticeable. In fact, the latter actors did not have a lot of influence on the issue, since mass media only reported the actors who took real action as preserving environment.

\subsubsection{Deforestation and Decentralized Forest Governance}

The high rate of deforestation in Indonesia and its impact has become a concern of the world. Sunderlin and Resosudarmo (1996) mentioned meaningful publications stated that deforestation in the 1990s was caused mainly by shifting cultivation, transmigration growth of population. Similar conclusion derived by data from the Ministry of Forestry indicated that $66 \%$ of deforestation was caused by commercial, local and subsistence agriculture (Kissinger et al., 2012). However, issues related to deforestation are often associated with corruption, weak law enforcement, inappropriate policy and the inability of central government to manage the forest (Suparna, 2001; FWI \& GFW, 2002). These arguments then led to a rethink of authority sharing between central and local governments in forest management. In CGI meeting in 2001, forestry decentralization was agreed as a condition of loan debt. The central government then issued a series of regulations called forest policy reform. However, the deforestation rate has even peaked in the decentralization era (Nurrochmat, 2005).

Public deliberation

The Secretary General of APHI recognized local autonomy as the driving factor of deforestation. He said regional autonomy provides the opportunity for regents to issue concessions of less than 30 thousand hectares according to Law No. 22/1999 on Regional Government. Unfortunately, these licenses did not meet with sustainable forest management practices, and massive deforestation occurred in most of the forest-rich districts (Media Indonesia, 2012). Supporting this claim, some of former heads of districts have been tried in court for 
forestry-related crimes (Kompas, 2012b). Environmental organizations such as WWF, Indonesia Working Group on Forest Finance (IWGFF) and Transparency International Indonesia (TII) stated that decentralization opened space for corruption and collusion in natural resource utilizations (Gatra, 2012). The Director General of Forest Protection and Nature Conservation of the MoF reported that potential losses due to inappropriate permits during the era of decentralization reached IDR 276.4 trillion, including 770 illegal logging cases and 1724 for mining from 2004 until 2012 in eight provinces (Kompas, 2012c).

Expert deliberation

The United Nations Environment Programme (UNEP)'s report entitled Green Carbon, Black Trade mentioned rampant deforestation and illegal timber trade in various parts of the world caused by organized crime. In Indonesia, it was caused mainly by corruption at upper and lower state levels and system failure (Nellemann \& INTERPOL Environmental Crime Programme, 2012). The MoF realized the decentralization process has not shown meaningful progress yet. Conflicts and disharmonized power sharing between central and local governments have enlarged opportunities in unsustainable forest utilizations and led to new pressure on forests (Kementerian Kehutanan, 2010). On the other hand, the central government seems to be very careful in setting new policies to avoid accusations of recentralization. Apparently, decentralization brought trouble and confusion for Indonesia in the middle of a desire to create greater regional autonomy (Kadjatmiko, 2008). Many researchers emphasized formulating suitable policy regarding forest decentralization. For instance, CIFOR has conducted 14 studies on decentralization and forest throughout Indonesia during period 2001-2005.

The central and local governments and environmental organizations are the main actors playing important roles in this issue. The central government has to share its power with local governments for decentralization to work. In the meantime, it also faces heavy international pressure to manage the environment well. Local governments for their part harness unstable decentralization to profit from forest utilizations. On this point, environmental organizations come and use national and international publications to warn about long-term environmental damage.

\section{Discussion}

\subsection{Public versus Expert Deliberations}

There are three differences in how the issues were presented in public and expert discourse deliberation. First, public mass media did not pay much attention to issues that did not have direct and immediate importance for the citizen, i.e.: harmonization of wood and forest certification schemes and land use change. This means that public mass media consider public preferences for their articles and ignore irrelevant topics for short-term interests of society. Second, public deliberations also differ from expert deliberations in terms of the depth of information. Third, public deliberations only touch debates on policymaking process and its implementation, while the expert's give long-term strategic discussions, policy options, studies on policy impacts and dialogue space among interested groups. This deliberative behavior is quite similar to what happened in Bangladesh, Brazil, Bolivia, Peru, and other countries (see: Kleinschmit, 2012; Leipold, 2014; Medina et al., 2009; Sadath, 2012; Sadath et al., 2013; Sadath \& Krott, 2012).

\subsection{The Most Active Actors}

The Ministry of Forestry is the most active actor in all issues. Another active actor is the Ministry of Trade, which actively involved in three issues, namely timber legality, harmonization of wood and forest certification scheme, as well as oil palm plantation and its environmental aspects. It indicates that forest-related issues at an international level are closely related to international trade and business (Humphreys, 2009). In these cases, the Ministries of Forestry as well as the Ministry of Trade work in similar directions, primarily in order to get Indonesian natural products into EU and the US markets (Kementerian Kehutanan, 2012a; 2012b; Nurrochmat et al., 2014; Cashore \& Stone, 2012; Iben et al., 2014). This is surprising as the theory of bureaucratic politics suggest only a single actor has dominant role in a particular sector (Peters, 2010) and intersection of responsibilities among state bureaucracies will create conflict of interests and unproductive contestation (Sahide \& Giessen, 2015; similar Ongolo, 2015; Hogl et al., 2009). Future studies must scrutinize this relationship not based on discursive contributions, but on on-going politics.

This study also finds industrial groups, namely wood-based industry and oil palm plantation groups, involved in five of the seven issues. Most industries support foreign trade policies issued by the Ministry of Forestry and the Ministry of Trade even though some of them disagree on the certification policy for downstream industries (similar Obidzinski et al., 2014). However, they are in conflict with WWF and Greenpeace, who oppose these industries as destructive to the forest and environment. Industrial groups still demand proof of these allegations. 
Environmental groups were another active actor that was present in almost issues. In the case of timber legality and harmonization of wood and forest certification schemes, both industry and WWF tend to a similar direction although each group has its own interests.

\subsection{The "Missing” Actors}

The roles of scientists and indigenous people were not apparently clear on these issues. Scientists' role in analyzing issues is limited to scientific and policy discussions among themselves, not in the public media. This finding is in line with prior findings on the limited impact of scientific experts on public deliberation (e.g. Sadath, 2012; Grundmann, 2009; Giessen et al., 2009; Hasanagas, 2014; Ekayani et al., 2015). Meanwhile, Aliansi Masyarakat Adat Nusantara (AMAN), as a representative of indigenous people, tries to circulate information regarding their predicament through several channels of group and social media. However, the complexity of the social order and conflicting interests among indigenous people makes this problem quite difficult to rise in public mass media, let alone at an international level.

\subsection{Issues in International Forest Regime Complex versus Domestic Issues}

The results suggest that the issues of timber legality, forest conversions, and climate change are now become the major topics discussed by the MoF. These issues demonstrate that the MoF puts more concern on production function of forest rather than to its non-economic functions. Pressures by environmental NGOs through their international networks still unable to bring more conservational and social issues -as elements of sustainable forest management- like endangered species protection, poverty alleviation of forest-dependent people, and local people rights' recognition into the MoF's priority programs. This fact strengthens claim mentioning although many issues available in international negotiations on and related to forest resource (Humphreys, 2006), bureaucracies always choose the most appropriate ones, according to their interests. It also clarifies that some issues may be applicable for certain country within specific period, while some others are not (Giessen et al., 2014).

\section{Conclusion}

This paper has identified seven current international forest-related issues in Indonesia: timber legality; harmonization of wood and forest certification schemes; oil palm plantation and its environmental aspects; land use change; climate change including REDD initiative; forest and species conservation; and deforestation and decentralized forest governance. These issues are also observed work in Bangladesh (Rahman \& Giessen, 2014) and Argentina (Burns \& Giessen, 2014), and strengthen a notion mentioning recent global initiatives on forest spin around issue of forest sustainability, legal timber and REDD+ (McDermott, 2012). Two issues that are more technical as well as potentially contentious, specifically harmonization of wood and forest certification schemes and land use change were not present in public deliberations, but rather remained limited to expert circles. Hence the IFRC seems to be relevant in many ways in Indonesia. The issues identified do cover a wide range of policy domains described by Humphreys (2006) and Giessen (2012). In Indonesia, global climate agreements are made relevant through REDD, endangered species conservation is discussed and free trade issues are touched upon by timber legality and certification issue. However, elements of indigenous people, desertification, CBD and SFM are not discussed in Indonesian public and expert deliberations.

Altogether the issues show that the most active actors in public and expert deliberations are the Ministry of Forestry and the Ministry of Trade, environmental NGOs like WWF and Greenpeace as well as wood and palm oil industry groups. This suggests that the competition of public bureaucracies and their societal clientele (i.e. ministries, see Peters, 2010; Rayner et al., 2001; Hogl et al., 2009; Giessen 2010a; 2010b; and Giessen \& Krott, 2009; Krott \& Hasanagas, 2006) is an important driver of forest-related issues and politics in Indonesia. Their contribution to the issues indicates a relatively weak coalition on forest protection, whereas forest utilizations and trade interests seem to be rather strong. Moreover, the main lines of conflict as represented in the issues lie between forest utilizations (e.g. for profitable timber or other land use) and forest conservation, which is in line with research by Winkel (2007). This study only analyses the issues measured by more or less public statements in newspapers, expert journals and so forth. These only indicate the formal claims and positions of the actors which they are willing to display in more or less public deliberations in public and expert arena (Krott, 1990; Kleinschmit, 2012). Based only on this data on formal statements, the authors draw conclusions on which issues from the IFR are made relevant in Indonesia. Other issues which may become relevant based on informal goals of specific actors cannot be revealed by this study.

\section{Acknowledgments}

This research has been kindly supported by the Indonesia Ministry of Research and Higher Education (Dikti), the 
Eva Mayr-Stihl Stiftung, the German Research Foundation under the project "Fragmentation of the International Forest Regime Complex" (PAK813), as well as the German Academic Exchange Service (DAAD).

\section{References}

Agro Indonesia. (2010). GAPKI: Tak mungkin moratorium pengembangan sawit. Retrieved from http://agroindonesia.co.id/2010/05/27/gapki-tak-mungkin-moratorium-pengembangan-sawit/

Agro Indonesia. (2011a). RI tantang UE teliti kebun sawit. Retrieved from http://agroindonesia.co.id/ 2011/10/25rspo-untuk-kepentingan-siapa/

Agro Indonesia. (2011b). RSPO untuk kepentingan siapa? Retrieved from http://agroindonesia.co.id/ 2011/10/25/rspo-untuk-kepentingan-siapa/

Agro Indonesia. (2011c). Seluas 64 juta hektare hutan di-verboden. Retrieved from http://agroindonesia.co.id/ 2011/05/23/seluas-64-juta-hektare-hutan-di-verboden/

Agro Indonesia. (2012a). Legalitas yang memangkas daya saing? Retrieved from http://agroindonesia.co.id/ 2012/01/25/legalitas-yang-memangkas-daya-saing/

Agro Indonesia. (2012b). Lokal pun mulai sadar lingkungan. Retrieved from http://agroindonesia.co.id/ 2012/06/19/masalah-indonesia-legitimasi-bukan-legalitas/

Agro Indonesia. (2012c). Indonesia akan paksa implementasi VPA. Retrieved from http://agroindonesia.co.id/ 2012/10/02/indonesia-akan-paksa-implementasi-vpa/

Agro Indonesia. (2012d). Indonesia pertanyakan komitmen Uni Eropa. Retrieved from http://agroindonesia.co.id/2012/10/02/indonesia-pertanyakan-komitmen-uni-eropa

Agro Indonesia. (2012e). Masalah Indonesia: legitimasi, bukan legalitas. Retrieved from http://agroindonesia.co.id/2012/06/19/masalah-indonesia-legitimasi-bukan-legalitas/

Agro Indonesia. (2012f). Pengusaha hutan makin peduli kelestarian. Retrieved from http://agroindonesia.co.id/ 2012/06/19/pengusaha-hutan-makin-peduli-kelestarian/

Agro Indonesia. (2012g). Berharap ada pengakuan bersama. Retrieved from http://agroindonesia.co.id/ 2012/06/19/pengusaha-hutan-makin-peduli-kelestarian/

Agro Indonesia. (2012h). AS ulur waktu soal minyak sawit. Retrieved from http://agroindonesia.co.id/ 2012/06/27/as-ulur-waktu-soal-minyak-sawit/

Agro Indonesia. (2012i). UKP4 pangkas luas pemilikan kebun. Retrieved from http://agroindonesia.co.id/ 2012/08/28/ukp4-pangkas-luas-pemilikan-kebun/

Agro Indonesia. (2012j). Norwegia kritik moratorium RI. Retrieved from http://agroindonesia.co.id/ 2012/05/29/norwegia-kritik-moratorium-ri

Antara. (2012a). Kemendag akan pertanyakan kesiapan SVLK Uni Eropa. Retrieved from http://www.antaranews.com/berita/335804/kemendag-akan-pertanyakan-kesiapan-svlk-uni-eropa

Antara. (2012b). Greenpeace keluarkan rapor perusahaan sawit di Indonesia. Retrieved from http://www.antaranews.com/berita/341119/greenpeace-keluarkan-rapor-perusahaan-sawit-di-indonesia

Bernstein, S., \& Cashore, B. (2012). Complex global governance and domestic policies: Four pathways of influence. International Affairs, 88(3), 585-604. http://dx.doi.org/10.1111/j.1468-2346.2012.01090.x

Bisnis Indonesia. (2011). Gapki resmi keluar dari RSPO. Retrieved from http://www.bisnis.com/ articles/gapki-resmi-keluar-dari-rspo

Bisnis Indonesia. (2012). Pengusaha kehutanan minta model sertifikasi lacak balak kayu disinergikan. Retrieved from http://www.bisnis.com/articles/pengusaha-kehutanan-minta-model-sertifikasi-lacak-balak-kayu-disinergikan

Brockhaus, M., Obidzinski, K., Dermawan, A., Laumonier, Y., \& Luttrell, C. (2012). An overview of forest and land allocation policies in Indonesia: Is the current framework sufficient to meet the needs of REDD+? Forest Policy and Economics, 18, 30-37.

Burns, S. L., \& Giessen, L. (2014). Identifying the main actors and their positions on international forest policy issues in Argentina. Bosque, 35(2), 163-173. http://dx.doi.org/10.4067/S0717-92002014000200004

Cashore, B., \& Stone, M. W. (2012). Can legality verification rescue global forest governance? Analyzing the potential of public and private policy intersection to ameliorate forest challenges in Southeast Asia. Forest Policy and Economics, 18, 13-22. http://dx.doi.org/10.1016/j.forpol.2011.12.005 
Chasek, P., Downie, D. L., \& Welsh Brown, J. (2014). Global environmental politics (6th ed.). Boulder: Westview Press.

Ekayani, M., Nurrochmat, D. R., \& Darusman, D. (2015). The role of scientists in forest fire media discourse and its potential influence for policy-agenda setting in Indonesia. Forest Policy and Economics. http://dx.doi.org/10.1016/j.forpol.2015.01.001

Forest Watch Indonesia [FWI] \& Global Forest Watch [GFW]. (2002). The state of the forest: Indonesia. Jakarta and Washington: Forest Watch Indonesia [FWI] \& Global Forest Watch [GFW].

Gatra. (2012). Korupsi \& pencucian uang pun jadi penyebab degradasi hutan. Retrieved from http://www.gatra.com/nusantara/nasional/20180-korupsi-pencucian-uang-pun-jadi-penyebab-degradasi-hutan.html

Giessen, L. (2010a). Regional governance für ländliche Räume-innovativer ansatz, politischer Gegenwind und der Weg vorwärts. Raumforschung und Raumordnung, 68(1), 3-14. http://dx.doi.org/10.1007/s13147-009-0009-7

Giessen, L. (2010b). Regional forest governence-potentials for forestry and political drivers in integrated rural development policy. Goettingen: Goettingen University Press, 313pp.

Giessen, L. (2012). Temporary governance and persistent government-rural policy integration in pilot and mainstream funding programmes. In K. Hogl, E. Kvarda, R. Nordbeck, \& M. Pregernig (Eds.), Environmental governance: the challenge of legitimacy and effectiveness (pp. 155-177). Massachusetts: Edward Elgar. http://dx.doi.org/10.4337/9781849806077.00017

Giessen, L., \& Krott, M. (2009). Forestry joining integrated programmes? A question of willingness, ability and opportunities. Allgemeine Forst- und Jagdzeitung, 180(5-6), 94-100.

Giessen, L., Kleinschmit, D., \& Böcher, M. (2009). Between power and legitimacy-discourse and expertise in forest and environmental governance. Forest Policy and Economics, 11(5-6), 452-453. http://dx.doi.org/10.1016/j.forpol.2009.08.002

Giessen, L., Krott, M., \& Möllmann, T. (2014): Increasing representation of states by utilitarian as compared to environmental bureaucracies in international forest and forest-environmental policy negotiations. Forest Policy and Economics, 38, 97-104. http://dx.doi.org/10.1016/j.forpol.2013.08.008

Grundmann, R. (2009). The role of expertise in governance processes. Forest Policy and Economics, 11(5-6), 398-403. http://dx.doi.org/10.1016/j.forpol.2008.09.005

Harian Terbit. (2012a). UE hanya terima kayu SVLK. Retrieved from http://www.harianterbit.com/ 2012/07/24/ue-hanya-terima-kayu-svlk/

Harian Terbit. (2012b). Menhut tolak usulan pengusaha. penerapan sertifikasi kayu tetap 21 Desember. Retrieved from http://www.harian terbit.com/2012/09/12/menhut-tolak-usulan-pengusaha/

Hasanagas, N. D. (2014). Managing information in forest policy networks: Distinguishing the influential actors from the "postmen". Forest Policy and Economics. http://dx.doi.org/10.1016/j.forpol.2014.09.007

Hogl, K., Nordbeck, R., \& Kvarda, E. (2009). When international impulses hit home: The role of domestic policy subsystem configurations in explaining different types of sustainability strategies. Forest Policy and Economics, 11(5-6), 357-364. http://dx.doi.org/10.1016/j.forpol.2008.07.003

Howlett, M., \& Ramesh, M. (1995). Studying public policy: policy cycles and policy subsystems (2nd ed.). Toronto: Oxford University Press.

Humphreys, D. (2006). Logjam: deforestation and the crisis of global governance. London: Earthscan.

Humphreys, D. (2009). Discourse as ideology: Neoliberalism and the limits of international forest policy. Forest Policy and Economics, 11(5), 319-325. http://dx.doi.org/10.1016/j.forpol.2008.08.008

Iben, N., Hansen, C. P., \& Cashore, B. (2014). Timber legality verification in practice: Prospects for support and institutionalization. Forest Policy and Economics, 48, 1-5. http://dx.doi.org/10.1016/j.forpol.2014.11.001

International Tropical Timber Organization [ITTO]. (2011). Annual review and assessment of the world timber situation 2011. Yokohama: International Tropical Timber Organization [ITTO].

Investor Daily Indonesia. (2012). Tak ada sawit indonesia yang merusak lingkungan. Retrieved from http://www.investor.co.id/agribusiness/tak-ada-sawit-indonesia-yang-merusak-lingkungan/39387

Kadjatmiko. (2008). Implementing decentralisation: lessons from experiences in Indonesia. In C. J. P. Colfer, G. 
R. Dahal, \& D. Capistrano (Eds.), Lessons from forest decentralisation: money, justice and the quest for good governance in Asia-Pacific. London: Earthscan.

Kementerian Kehutanan. (2010). Strengthening forest administration. integrative research planning 2010-2014. Document Retrieved from http://forda-mof.org/files/RPI_24_Penguatan_Tatakelola_Kehutanan.pdf

Kementerian Kehutanan. (2012a). Kemenhut launching sistem informasi legalitas kayu. Siaran pers. Retrieved from http://www.dephut.go.id/index.php?q=id/node $/ 8547$

Kementerian Kehutanan. (2012b). Uji pengapalan ekspor produk kayu bersertifikat ke Uni Eropa. Siaran pers. Retrieved from http://www.dephut.go.id/index.php?q=id/node/8649

Kissinger, G., Herold, M., \& De Sy, V. (2012). Drivers of deforestation and forest degradation: A synthesis report for REDD+ policymakers. Vancouver: Lexeme Consulting.

Kleinschmit, D. (2012). Confronting the demands of a deliberative public sphere with media constraints. Forest Policy and Economics, 16, 71-80. http://dx.doi.org/10.1016/j.forpol.2010.02.013

Kompas. (2009). REDD dituntut tidak tinggalkan masyarakat adat. Retrieved from http://nasional.kompas.com/ $\mathrm{read} / 2009 / 12 / 14 / 09421281 /$ REDD.Dituntut.Tidak.Tinggalkan.Masyarakat.Adat

Kompas. (2011a). Riau tuntut dimasukkan dalam REDD Indonesia-Norwegia. Retrieved from http://www.Media-indonesia.com/webtorial/tanahair/?bar_id=MjE3Njkw

Kompas. (2011b). Koordinasi pemerintah buruk. Retrieved from http://www.mediaindonesia.com/ webtorial/tanahair/?bar_id=MjYONDcx

Kompas. (2012a). SVLK cegah praktek log laundering. Retrieved from http://sains.kompas.com/ read/2012/08/01/18175122/svlk.cegah.praktek.log.laundering

Kompas. (2012b). Mantan bupati kampar dituntut 6 tahun penjara. Retrieved from http://cetak.kompas.com/ $\mathrm{read} / 2012 / 10 / 02 / 02490121 /$ mantan.bupati.kampar.dituntut.6.tahun.penjara

Kompas. (2012c). Hutan dirambah, negara rugi ratusan triliun. Retrieved from http://bisniskeuangan. kompas.com/read/2012/10/23/07424761/Hutan.Dirambah.Negara.Rugi.Ratusan.Triliun

Krasner, S. D. (1982). Structural causes and regime consequences: regimes as intervening variables. International Organization, 36(2), 185-205. http://dx.doi.org/10.1017/S0020818300018920

Krott, M. (1990). Öffentliche verwaltung im umweltschutz. ergebnisse einer behördenorientierten policy-analyse am beispiel waldschutz. Wien: Braumüller Verlag.

Krott, M., \& Hasanagas, N. D. (2006). Measuring bridges between sectors: Causative evaluation of $\begin{array}{lllll}\text { cross-sectorality. Forest Policy and } & \text { Economics, }\end{array}$ http://dx.doi.org/10.1016/j.forpol.2005.07.004

Leipold, S. (2014). Creating forests with words-A review of forest-related discourse studies. Forest Policy and Economics, 40, 12-20. http://dx.doi.org/10.1016/j.forpol.2013.12.005

Lindstad, B. H., \& Solberg, B. (2010). Challenges in determining national effects of international policy processes: forest protection in Norway as a case. Forest Policy and Economics, 12(7), 489-496. http://dx.doi.org/10.1016/j.forpol.2010.07.002

Majalah Kehutanan Indonesia. (2008). Dua harimau sumatera kembali ke hutan. 7, 36.

Majalah Kehutanan Indonesia. (2009a). Elang Jawa, burung asli indonesia yang kian hilang. 1, 30-31.

Majalah Kehutanan Indonesia. (2009b). Menteri Kehutanan canangkan pengembangan cendana di NTT. 2, 5-9.

Majalah Kehutanan Indonesia. (2009c). Selayang pandang kawasan konservasi mangrove dan bekantan. 1, 30-31.

Majalah Kehutanan Indonesia. (2010). Norwegia siap kucurkan dana REDD+ USD 1 miliar. 6, 12-13.

Majalah Kehutanan Indonesia. (2011a). Menhut janji kampanyekan legalitas kayu. 11, 5-6.

Majalah Kehutanan Indonesia. (2011b). Promosi kayu legal ala Indonesia-Uni Eropa. 5, 5-7.

Majalah Kehutanan Indonesia. (2011c). Perlu kompensasi nagara maju untuk kurangi GRK. 7, 29-31.

Majalah Kehutanan Indonesia. (2011d). Perdebatan moratorium berakhir. 6, 5-7.

Majalah Swa. (2012). Indonesia sumbang 48\% produksi minyak sawit dunia. Retrieved from http://swa.co.id/ business-research/indonesia-sumbang-48-produksi-minyak-sawit-dunia 
Maryudi, A., Devkota, R. R., Schusser, C., Yufanyi, C., Salla, M. Aurenhammer, H., Rotchanaphatharawit, R., \& Krott, M. (2012). Back to basics: Considerations in evaluating the outcomes of community forestry. Forest Policy and Economics, 14, 1-5. http://dx.doi.org/10.1016/j.forpol.2011.07.017

McDermott, C. L. (2014). REDDuced: From sustainability to legality to units of carbon-The search for common interests in international forest governance. Environmental Science \& Policy, 35, 12-19. http://dx.doi.org/10.1016/j.envsci.2012.08.012

McDermott, C. L., Cashore, B., \& Kanowski, P. (2010a). Global environmental forest policies: An international comparison. London: Earthscan.

McDermott, C. L., Humphreys, D., Wildburger, C., \& Wood, P. (2010b). Mapping the core actors and issues defining international forest governance. In J. Rayner, A. Buck, \& P. Katila (Eds.), Embracing complexity: meeting the challenges of international forest governance. A global assessment report (pp. 19-36). Prepared by the Global Forest Expert Panel on the International Forest Regime. IUFRO World Series Volume 28. Vienna.

Media Indonesia. (2010a). Indonesia surga sawit dunia. Retrieved from http://www.mediaindonesia.com/ webtorial/asianagri/?ar_id=Nzc1Ng

Media Indonesia. (2010b). Internasional akan terus menekan industri sawit. Retrieved from $\mathrm{http} / / /$ www.mediaindonesia.com/webtorial/tanahair/?bar_id=MTc3MDYy

Media Indonesia. (2011a). Indonesia-Uni Eropa ikat perjanjian legalitas perdagangan kayu. Retrieved from http://m.mediaindonesia.com/index.php/read/2011/03/22/212261/21/2/Indonesia-Uni_Eropa_Ikat_Perjanjia n_Legalitas_Perdagangan_Kayu.

Media Indonesia. (2011b). Produk kayu indonesia diakui Uni Eropa. Retrieved from http://www.mediaindonesia.com/read/2011/09/27/263023/4/2/-Produk-Kayu-Indonesia-Diakui-Uni-Eropa.

Media Indonesia. (2011c). Konservasi tambling lampung, bukti keseriusan indonesia cegah pemanasan global. Retrieved from http://www.mediaindonesia.com/read/2011/05/05/222543/89/14/Konservasi-Tambling -Lampung-Bukti-Keseriusan-Indonesia-Cegah-Pemanasan-Global

Media Indonesia. (2012). Otonomi daerah akibatkan penebangan hutan secara sporadis.. Retrieved from http://www. mediaindonesia.com/webtorial/tanahair/?bar_id=MzUxMzg4.

Medina, G., Pokorny, B., \& Weigelt, J. (2009). The power of discourse: hard lessons for traditional forest communities in the Amazon. Forest Policy and Economics, 11(5), 392-397. http://dx.doi.org/10.1016/j.forpol.2008.11.004

Mongabai Indonesia. (2012a). BKSDA Sulut pulangkan seekor macan tutul ke Jawa. Retrieved from http://www.mongabay.co.id/2012/11/15/bksda-sulut-pulangkan-seekor-macan-tutul-ke-jawa/

Mongabai Indonesia. (2012b). Kebijakan moratorium hutan tak cukup hanya dua tahun. Retrieved from http://www.mongabay.co.id/2012/10/01/kebijakan-moratorium-hutan-tak-cukup-hanya-dua-tahun/

Mongabai Indonesia. (2012c). Peta Wilayah Adat Diakomodir Masuk One Map Indonesia. Retrieved from http://www.mongabay.co.id/2012/11/15/peta-wilayah-adat-diakomodir-masuk-one-map/\#ixzz2CGjyh1F1

Nellemann, C., INTERPOL Environmental Crime Programme (Eds.). (2012). Green carbon, black trade: illegal logging, tax fraud and laundering in the worlds tropical forests. A rapid response assessment. United Nations Environment Programme, GRID-Arendal.

Nurrochmat, D. N. (2005). The impacts of regional autonomy on political dynamics, socio-economics and forest degradation: Case of Jambi-Indonesia. Göttingen: Cuvillier.

Nurrochmat, D. R., Dharmawan, A. H., Obidzinski, K., Dermawan, A., \& Erbaugh, J. T. (2014). Contesting national and international forest regimes: Case of timber legality certification for community forests in Central Java, Indonesia. Forest Policy and Economics. http://dx.doi.org/10.1016/j.forpol.2014.09.008

Obidzinski, K., Dermawan, A., Andrianto, A., Komarudin, H., \& Hernawan, D. (2014). The timber legality verification system and the voluntary partnership agreement (VPA) in Indonesia: Challenges for the small-scale forestry sector. Forest Policy and Economics, 48, 24-32. http://dx.doi.org/10.1016/j.forpol.2014.06.009

Ojha, H., Cameron, J., \& Kumar, C. (2009). Deliberation or symbolic violence? The governance of community forestry in Nepal. Forest Policy and Economics, 11, 365-374. http://dx.doi.org/10.1016/j.forpol.2008.11.003 
Ongolo, S. (2015). On the banality of forest governance fragmentation: Exploring "gecko politics" as a bureaucratic behaviour in limited statehood. Forest Policy and Economics. http://dx.doi.org/10.1016/j.forpol.2015.01.005

Overdevest, C., \& Zeitlin, J. (2014a). Assembling an experimentalist regime: Transnational governance interactions in the forest sector. Regulation \& governance, 8(1), 22-48. http://dx.doi.org/10.1111/j.1748-5991.2012.01133.x

Overdevest, C., \& Zeitlin, J. (2014b). Constructing a transnational timber legality assurance regime: Architecture, accomplishments, challenges. Forest Policy and Economics, 48, 6-15. http://dx.doi.org/10.1016/j.forpol.2013.10.004

Peters, B. G. (2010). The politics of bureaucracy-an introduction to comparative public administration (6th ed.). Oxon: Routledge.

Rahman, M. S., \& Giessen, L. (2014). Mapping international forest-related issues and main actors' positions in Bangladesh 1. International Forestry Review, 16(6), 586-601. http://dx.doi.org/10.1505/146554814814095294

Rayner, J., Buck, A. \& Katila, P. (Eds.). (2010). Embracing complexity: meeting the challenges of international forest governance. A global assessment report. Prepared by the Global Forest Expert Panel on the International Forest Regime. Vienna: IUFRO World Series Volume 28. p.172.

Rayner, J., Howlett, M., Wilson, J., Cashore, B., \& Hoberg, G. (2001). Privileging the sub-sector: Critical sub-sectors and sectoral relationships in forest policy-making. Forest Policy and Economics, 2(3-4), 319-332. http://dx.doi.org/10.1016/S1389-9341(01)00038-7

Republika Online (2011a). Gabungan pengusaha sawit keluar dari RSPO. Retrieved from http://www.republika.co.id/berita/nasional/umum/11/10/11/lsvl90-gabungan-pengusaha-sawit-keluar-dari-rs po

Republika Online. (2011b). AS hapus utang RI untuk konservasi hutan. Retrieved from http://www.republika.co.id/berita/ekonomi/keuangan/11/09/29/1s9tz7-as-hapus-utang-ri-untuk-konservasi-hutan

Rimbawan Interaktif. (2012a). Apa kabar SVLK. Message no. 37354.

Rimbawan Interaktif. (2012b). Abstract tentang FLEGT VPA dan SVLK. Message no. 36812-36814.

Rimbawan Interaktif. (2012c). Apa Kabar SVLK [How is SVLK]. Message no 37382.

Rimbawan Interaktif. (2012d). APEC CEO Summit 2012, SBY terus perjuangkan sawit. Message no 36883, 36886 , and 36887.

Rimbawan Interaktif. (2012e). Apa kabar LoI Norway? Message no 36672.

Rimbawan Interaktif. (2012f). Kompas: petisi daring-dari gambut hingga sirip hiu. Message no 37406.

Rimbawan Interaktif. (2012g). Orangutan terbakar saat evakuasi. Message no 37034 and 37035.

Sadath, M. N., \& Krott, M. (2012). Identifying policy change-Analytical program analysis: An example of two decades of forest policy in Bangladesh. Forest Policy and Economics, 25, 93-99. http://dx.doi.org/10.1016/j.forpol.2012.07.013

Sadath, N. (2012). Media as a driver of policy change: The example of forest-climate policy in Bangladesh. (Unpublished doctoral dissertation). University of Goettingen, Goettingen, Germany.

Sadath, N., Kleinschmit, D., \& Giessen, L. (2013). Framing the tiger-A biodiversity concern in national and international media reporting. Forest Policy and Economics, 36, 37-41. http://dx.doi.org/10.1016/j.forpol.2013.03.001

Sahide, M. A. K., \& Giessen, L. (2015). The fragmented land use administration in Indonesia-Analysing bureaucratic responsibilities influencing tropical rainforest transformation systems. Land Use Policy, 43, 96-110. http://dx.doi.org/10.1016/j.landusepol.2014.11.005

Smouts, M. C. (2008). The Issue of an International Forest Regime. International Forestry Review, 10(3), 429-432. http://dx.doi.org/10.1505/ifor.10.3.429

Steffek, J. (2009). Discursive Legitimation in Environmental Governance. Forest Policy and Economics, 11, 313-318. http://dx.doi.org/10.1016/j.forpol.2009.04.003

Suara Merdeka. (2012). Asmindo tolak sertifikasi legalitas kayu. Retrieved from http://www.suaramerdeka.com/ 
v1/index.php/read/news/2012/02/10/109171/Asmindo-Tolak-Sertifikasi-Legalitas-Kayu

Suara Pembaruan. (2012). APEC CEO Summit 2012, SBY terus perjuangkan sawit. Retrieved from $\mathrm{http} / /$ www.suarapembaruan.com/ekonomidanbisnis/apec-ceo-summit-2012-sby-terus-perjuangkan-sawit/24 426

Sunderlin W. D., \& Resosudarmo, I. A. A. P. (1996). Rates and causes of deforestation in Indonesia. Towards a resolution of the ambiguities. CIFOR Occasional Paper no. 9. Bogor: CIFOR.

Suparna, N. (2001). Forest governance and law enforcement in Indonesia. Paper presented at the Forest Law Enforcement \& Governance-East Asia: A Ministerial Conference. Bali, September 11-13.

The Jakarta Post. (2011). Bali starling breeding center opened. Retrieved from http://www.thejakartapost.com/ news/2011/11/09/bali-starling-breeding-center-opened.html

The Jakarta Post. (2012a). Gov't helps small timber product firms get SVLK certification. Retrieved from http://www.thejakartapost.com/news/2012/08/03/govt-helps-small-timber-product-firms-get-svlk-certificati on.html

The Jakarta Post. (2012b). EU postpones approval of RI timber products. Retrieved from http://www.thejakartapost.com/news/2012/09/26/eu-postpones-approval-ri-timber-products.html

The Jakarta Post. (2012c). Govt to counter negative campaign on cpo. Retrieved from $\mathrm{http}: / /$ www.thejakartapost.com/news/2012/04/14/govt-counter-negative-campaign-cpo.html

The Jakarta Post. (2012d). Stamps to spread the word on endangered birds. Retrieved from http://www.thejakartapost.com/news/2012/07/26/stamps-spread-word-endangered-birds.html

UN-REDD. (2012). Indonesia. UN-REDD country brief. Retrieved from http://www.fao.org/climatechange /unredd/53078/en/idn/

Winkel, G. (2007). Waldnaturschutzpolitik in Deutschland. bestandsaufnahmen, analysen und entwurf einer story-line. remagen-oberwinter (Dr. Kessel). Freiburger Schriften zur Forst-und Umweltpolitik 13, 561 p.

\section{Notes}

Note 1. This exploratory study is part and basis of a broader research project, which will subsequently analyse the implementation of the IFRC in Indonesia in more detail.

Note 2. These sources are available in the Internet at http://www. mediaindonesia.com/, http://kompas.com/, and http://www.thejakartapost.com/ respectively.

Note 3. These are available in the Internet at http://www.dephut.go.id/index.php? $\mathrm{q}=\mathrm{id} / \mathrm{node} / 5070$, $\mathrm{http}: / /$ agroindonesia.co.id/ and http://indonesia.mongabay.com/ respectively.

Note 4. Oil palm is the general name term of Elaeis guineensis crop while palm oil is the product that produces from oil palm fruit.

\section{Appendix A}

\section{Main Actors and Their Positions on Each Issue}

\begin{tabular}{lll}
\hline Issue & Main actors & Actors' main positions \\
\hline $\begin{array}{l}\text { Primary international forest-related issues } \\
\text { 1. Timber legality }\end{array}$ & Ministry of Forestry and & - Support FLEGT and VPA \\
& Ministry of Trade & - Produce legal instruments and force industries to \\
& & obey it \\
& & - Promote global recognition of SVLK \\
\cline { 2 - 3 } & Primary and large scale forest & - Support FLEGT and VPA \\
industries & - Willing to be certified \\
\cline { 2 - 2 } & Asmindo, APHI and downstream & - Support FLEGT and VPA \\
industries & - Not willing to be certified \\
& - Downstream industries' products automatically \\
\cline { 2 - 2 } & EU countries (Indonesian wood & - Postponed signing FLEGT and VPA three times \\
\hline
\end{tabular}




\begin{tabular}{|c|c|c|}
\hline \multirow[b]{4}{*}{$\begin{array}{l}\text { 2. Climate change } \\
\text { including REDD } \\
\text { initiative }\end{array}$} & products destination) & - Unclear position \\
\hline & WWF & - Support FLEGT, VPA and SVLK \\
\hline & Researchers and academics & $\begin{array}{ll}- & \text { Distrust EU commitment } \\
- & \text { Bilateral agreements more important than VPA } \\
\text { since the EU agreement is not legally binding } \\
-\quad \text { Push sustainable forest management practice to } \\
\text { build Indonesian wood products' legitimacy } \\
\text { - Warn about SVLK as new gateway for corruption }\end{array}$ \\
\hline & UKP4 and REDD+ Task Force & $\begin{array}{l}\text { - Indonesian representation in international forums } \\
- \text { Much interaction with international actor and less } \\
\text { power }\end{array}$ \\
\hline \multirow{7}{*}{$\begin{array}{l}\text { 3. Oil palm } \\
\text { plantation and its } \\
\text { environmental } \\
\text { aspects }\end{array}$} & Ministry of Forestry & - Technical actor \\
\hline & Scientists & $\begin{array}{l}\text { - Providing studies and conceptual frameworks for } \\
\text { government }\end{array}$ \\
\hline & Ministry of Forestry & - Permits for plantation \\
\hline & Ministry of Trade & $\begin{array}{l}\text { - Fight for acceptance of palm oil products without } \\
\text { any restriction and as a source of national income }\end{array}$ \\
\hline & $\begin{array}{l}\text { Indonesian Palm Oil Association } \\
\text { (GAPKI) }\end{array}$ & - Need to expand oil palm production \\
\hline & Greenpeace and WWF & $\begin{array}{l}\text { - Promote sustainable environment irrespective of } \\
\text { national policy }\end{array}$ \\
\hline & EU and US industries & $\begin{array}{l}\text { - Protect domestic vegetable oil production by } \\
\text { blocking palm oil imports }\end{array}$ \\
\hline \multicolumn{3}{|c|}{ Secondary international forest-related issues } \\
\hline \multirow{4}{*}{$\begin{array}{l}\text { 1. Harmonization of } \\
\text { wood and forest } \\
\text { certification } \\
\text { schemes }\end{array}$} & $\begin{array}{l}\text { Ministry of Forestry } \\
\text { and Ministry of Trade }\end{array}$ & $\begin{array}{ll} & \text { Fight for SVLK in buyer countries } \\
\text { - } & \text { Recognize voluntary scheme and expect the } \\
& \text { opposite for SVLK }\end{array}$ \\
\hline & Indonesian timber industry & $\begin{array}{l}- \text { Want mutual recognition between two kinds of } \\
\text { certification so that they could get both at once }\end{array}$ \\
\hline & $\begin{array}{l}\text { WWF and other environmental } \\
\text { organizations }\end{array}$ & $\begin{array}{l}\text { - Support FSC becoming the powerful and } \\
\text { well-accepted wood and forest certification } \\
\text { scheme }\end{array}$ \\
\hline & $\begin{array}{l}\text { FSC, LEI, PEFC and SVLK } \\
\text { scheme owners }\end{array}$ & $\begin{array}{l}\text { - Fight for their scheme to be recognized by buyers } \\
\text { and accepted by industry }\end{array}$ \\
\hline \multirow[t]{6}{*}{ 2. Land use change } & UKP4 and REDD Task Force & $\begin{array}{l}\text { - Makes policies related to national strategy for } \\
\text { land utilization }\end{array}$ \\
\hline & Ministry of Forestry & $\begin{array}{l}\text { - Maintain control over forest land use } \\
-\quad \text { Keep land use change as their concern } \\
\end{array}$ \\
\hline & Plantation companies (GAPKI) & $\begin{array}{l}- \text { Need to expand oil palm plantation } \\
-\quad \text { Consider restrictions a business obstacle } \\
-\quad \text { Worry about influence of foreign lobby on } \\
\text { Indonesian policy making }\end{array}$ \\
\hline & Indigenous peoples & - Secure their land from occupation by companies \\
\hline & Greenpeace & $\begin{array}{l}\text { - Prohibit Indonesia from utilizing primary and } \\
\text { secondary forests and peat lands }\end{array}$ \\
\hline & Scientists & $\begin{array}{l}\text { - Counsel government to balance economic } \\
\text { development and environmental protection }\end{array}$ \\
\hline \multirow[t]{2}{*}{$\begin{array}{l}\text { 3. Forest and species } \\
\text { conservation }\end{array}$} & Ministry of Forestry & $\begin{array}{l}- \text { Protect genetic resources and consider it a } \\
\text { precious heritage the future }\end{array}$ \\
\hline & $\begin{array}{l}\text { Forest companies and } \\
\text { conservation organizations }\end{array}$ & $\begin{array}{l}\text { - Participate in environmental preservation and } \\
\text { species conservation }\end{array}$ \\
\hline \multirow[t]{2}{*}{$\begin{array}{l}\text { 4. Deforestation and } \\
\text { decentralized }\end{array}$} & $\begin{array}{l}\text { Central government (Ministry of } \\
\text { Forestry) }\end{array}$ & - Secure forest for diplomatic purposes \\
\hline & Local government & - Utilize forest and other idle natural resources as \\
\hline
\end{tabular}


forest governance source of income

WWF, IWGFF, TII $\quad-$ Produce and utilize reports of poor forest management in Indonesia in widespread forums

\section{Appendix B}

\section{Acronyms and Abbreviations}

AMAN Aliansi Masyarakat Adat Nusantara (Indigenous Peoples' Alliance of the Archipelago)

APHI Asosiasi Pengusaha Hutan Indonesia (Association of Indonesian Forest Concessionaires)

Apindo Asosiasi Pengusaha Indonesia (Indonesian Enterprises Association)

Asmindo Asosiasi Industri Permebelan dan Kerajinan Indonesia (Indonesian Furniture Industry and Handicraft Association)

CBD Convention on Biological Diversity

CGI Consultative Group on Indonesia

CIFOR Center for International Forestry Research

EU European Union

FAO Food and Agriculture Organization

FLEGT Forest Law Enforcement, Governance and Trade

FSC Forest Stewardship Council

GAPKI Gabungan Pengusaha Kelapa Sawit Indonesia (Indonesian Palm Oil Association)

IFR International Forest Regime

IFRC International Forest Regime Complex

ISPO Indonesian Sustainable Palm Oil

ITTO International Tropical Timber Organization

MoF Ministry of Forestry

NGO Non-Governmental Organization

PEFC Programme for the Endorsement of Forest Certification

REDD Reducing Emissions from Deforestation and Forest Degradation

RSPO Roundtable on Sustainable Palm Oil

SFM Sustainable Forest Management

SMEs Small and Medium Scale Enterprises

SVLK Sistem Verifikasi Legalitas Kayu (Timber Legality Verification System)

UKP4 Unit Kerja Presiden Bidang Pengawasan dan Pengendalian Pembangunan (Presidential Delivery Unit for Development Monitoring and Oversight)

VPA Voluntary Partnership Agreements

WTO World Trade Organization

WWF World Wide Fund for Nature

\section{Copyrights}

Copyright for this article is retained by the author(s), with first publication rights granted to the journal.

This is an open-access article distributed under the terms and conditions of the Creative Commons Attribution license (http://creativecommons.org/licenses/by/3.0/). 


\title{
Absolute and relative power gains among state agencies in forest-related land use politics: The Ministry of Forestry and its competitors in the REDD+ Programme and the One Map Policy in Indonesia
}

\author{
Agung Wibowo ${ }^{\mathrm{a}, \mathrm{b}, *}$, Lukas Giessen ${ }^{\mathrm{a}}$ \\ a Chair Group of Forest and Nature Conservation Policy, Georg-August-Universität Göttingen, Büsgenweg 3, 37077 Göttingen, Germany \\ ${ }^{\mathrm{b}}$ Faculty of Agriculture, University of Palangka Raya, Kampus UNPAR Tunjung Nyaho, Jl. Yos Sudarso PO BOX 2/PLKUP, 73111 Palangka Raya, Indonesia.
}

\section{A R T I C L E I N F O}

\section{Article history:}

Received 5 July 2014

Received in revised form 7 July 2015

Accepted 17 July 2015

\section{Keywords:}

Power theory

Bureaucratic politics

Norway-Indonesia LoI

REDD+ Programme

The Ministry of Forestry

International influences

\begin{abstract}
A B S T R A C T
More than ever, state agencies responsible for forest issues are required to balance the social, economic and environmental demands on forests in domestic and international spheres. New and often crosscutting issues may threaten the position and power of traditional forest bureaucracies through, e.g., a redistribution of power among a number of other land-use-related state agencies. This paper analyzes the absolute and relative power of the Ministry of Forestry (MoF) in two selected policy processes originating on the international and domestic levels, namely the REDD+ Programme and the One Map Policy. Building on a behavioralist conception of power and bureaucratic politics theories, we study these processes to reveal the power dynamics between the MoF and other state bureaucracies, based mainly on documents on tasks assigned to these bureaucracies. Our results show a clear decline in the relative power of the MoF, most notably in the case of incentive and coercive power, though we also show a continuation of power resulting from dominant information. However, due to political intervention from the new president, traditional forest bureaucracy is now reclaiming most of relative power elements in these cases. We discuss the core findings and conclude that both REDD+ and the One Map Policy are likely to become effective policies only if the bureaucratic, sectoral and multi-level conflicts of interest we examine are addressed and fewer leading agencies (or one) assume responsibility for policy formulation and implementation.
\end{abstract}

(c) 2015 Elsevier Ltd. All rights reserved.
Abbreviations: BAPPENAS, Badan Perencanaan Pembangunan Nasional (National Development Planning Agency); BIG, Badan Informasi Geospasial (Geospatial Information Agency); BPN, Badan Pertanahan Nasional (National Land Agency); DNPI, Dewan Nasional Perubahan Iklim (National Council on Climate Change); GtCO2e, Giga metric tons of carbon dioxide equivalent; Inpres, Instruksi Presiden (Presidential Instruction); Kepres, Keputusan Presiden (Presidential Decree); MoA, Ministry of Agriculture; MoDA, Ministry of Domestic Affairs; MoE, Ministry of Environment; MoEF, Ministry of Environment and Forestry; MoEMR, Ministry of Energy and Mineral Resource; MoF, Ministry of Forestry; MoFi, Ministry of Finance; MoLHR, Ministry of Law and Human Rights; MoPW, Ministry of Public Works; MoSE, Ministry of State Enterprises; MoT, Ministry of Trade; Perpres, Peraturan Presiden (Presidential Regulation); RAN-GRK, Rencana Aksi Nasional-Penurunan Gas Rumah Kaca (National Action Plan for Greenhouse Gas Emissions Reduction); RAD-GRK, Rencana Aksi Daerah-Penurunan Gas Rumah Kaca (Regional Action Plan for Greenhouse Gas Emissions Reduction); UKP4, Unit Kerja Presiden Bidang Pengawasan dan Pengendalian Pembangunan (Presidential Delivery Unit for Development Monitoring and Oversight); UNFCCC, United Nation Framework Convention on Climate Change.

* Corresponding author.

E-mail addresses: agung.wibowo@stud.uni-goettingen.de (A. Wibowo), lgiesse@gwdg.de (L. Giessen).

\section{Introduction}

More than ever, state agencies responsible for forest issues are required to balance the social, economic and environmental demands on forests in domestic and international spheres (Sayer and Collins, 2012; Mwangi and Wardell, 2012; Maryudi, 2012; Giessen, 2012; Giessen and Krott, 2009). These new and often cross-cutting issues may threaten traditional forest bureaucracies through, e.g., a redistribution of power among a number of land-use-related state agencies. Fundamentally, state agencies, as bureaucratic politics and related literature reveal (e.g., Krott, 2005; Olsen, 2006; Peters, 2001; Giessen et al., 2014; Buijs et al., 2014; Kumar and Kant, 2005; Bennett et al., 2012, 2013), compete for power in the form of formal mandates to pursue policies in these emerging issue areas and to acquire staff and budgets. This competition for power has been identified as an important factor in land use and forest politics (Pedersen, 2010; Krott et al., 2014; Aurenhammer, 2011, 2012; Ojha et al., 2014; Ongolo, 2015). In this competition, the agencies use both domestic and international 
issues to strengthen their negotiation positions vis-à-vis competing agencies. They do this by framing and taking up issues, discourses and rules to legitimize their roles and by finding domestic and/or international coalition partners (Bernstein and Cashore, 2012; Giessen, 2011, 2013).

Indonesia is affected by multiple claims from various national and international groups regarding the utilization and conservation of forests (Brockhaus et al., 2012). These claims include forest certification, land tenure, forest biodiversity, forest carbon sequestration and REDD+, as well as the One Map Policy on competing land uses (see Wicke et al., 2011; Wibowo and Giessen, 2015; McDermott, 2014; Sahide and Giessen, 2015). These crosscutting and forest-related claims have the potential to challenge and change the power of the Ministry of Forestry (hereafter MoF), the traditional bureaucracy in charge of forest issues (similar Burns and Giessen, 2015). Additionally, stakeholders have long been disappointed with the MoF, which is often associated with corruption, a lack of openness of data and information, and a disregard for crimes taking place in forests. These concerns have led to vast domestic and international criticism and an effort to reduce the MoF's power over forest governance, in favor of competing state agencies (Brown, 1999; Palmer, 2001; Barr, 2006; Singer, 2008).

This paper analyzes the power dynamics of the Ministry of Forestry $(\mathrm{MoF})$ vis-à-vis its competitor bureaucracies in two selected policy processes originating from international and domestic levels, namely the REDD+ Programme and the One Map Policy. In particular, we analyze the means of power these bureaucracies have at hand and changes in the equipment of these power resources. We argue that individual policy processes can increase or decrease the MoF's equipment of these power resources, mainly due to policy tasks being assigned to an agency. It is possible that in one case, the MoF may both lose and gain power resources such as dominant information, (dis-)incentives and coercive power. We hypothesize that the cases in which the observed specific power resources of the MoF are eroded are mainly due to it now sharing responsibilities with other agencies, which often are new to the field of forest policy.

In the following sections, we introduce bureaucratic politics and power theory as our main analytical tools and describe some of our major methodological choices in detail. Section 3 then explores the power dynamics between the bureaucracies involved in the two policy processes mentioned above, with special attention given to the particular power elements bureaucracies may lose or gain and to the bureaucracies that gain at the expense of others. We then discuss both the increase and decrease in the power elements of the MoF in the selected cases in light of the indicators for power gains in other fields, before presenting our conclusions.

\section{Methodology}

\subsection{Analytical framework}

\subsubsection{Bureaucratic politics theory}

Any internal and external actors ${ }^{1}$ keen to influence domestic policy have to meet and deal with the state's official system, known as the "bureaucracy" (Peters, 2001; Biermann et al., 2009). Bureaucracies have a formal goal in serving the public interest and an informal goal in surviving and expanding organizational interests, like maximizing power, budget and staff. Those organizational interests are prioritized if formal and informal goals

\footnotetext{
1 Actor is defined as an individual, a group of people or an organization with the capacity and legitimacy to exercise power, where legitimacy is achieved by obtaining, formally or informally, the consent of the governed (Biermann, 2010 c.f. Brockhaus et al., 2014).
}

cannot be achieved simultaneously (Niskanen, 1974; Krott, 1990; Giessen and Krott, 2009; Giessen et al., 2014). Although this seems to be logical, the behavior of a bureaucracy, as noted above, is not homogenous because it depends on the capability of each bureaucracy to achieve its own benefits (Blais and Dion, 1990). To pursue those dual goals, bureaucracies can act as political institutions and administrative bodies (Krott, 2005). As political institutions, they are equipped with legitimacy, public mandate, financial resources and competent staffs, and as administrative bodies, bureaucracies have expertise and information, administrative ideology, decisionmaking power, alliances, permanent positions, and a disregard for politics.

Whether and how international or domestic actors affect policy change, however, are greatly influenced by the openness of local bureaucracies to such policy change, as well as by their interests (informal goals) and formal tasks. Whether a given situation is one in which a significant policy change might also influences this process. These processes of changes are frequently transferred by intentional actors, such as international bureaucracies, global corporations and science networks (Biermann and Pattberg, 2012), and by local actors, such as veto players and ruling political parties, before being captured by local bureaucracies through policy learning, ideas and discourses, the internationalization of global issues, policy networks, bureaucratic reform, and institutional change (Giessen et al., 2014). However, those external interests should go through five stages of policy cycle, namely agenda setting, policy formulation, decision making, policy implementation and policy evaluation (Howlett and Ramesh, 1995), before coming into force. The absence of external actors, the implantation process of their interests and the policy process to respond to these interests will ensure no changes in public policy and that the bureaucracy tends to be stable or pro status quo.

\subsubsection{Power theory}

The power of actors has long been discussed by sociology, psychology, communications, management and political scholars. A more advanced and influential concept of the power of actors was delivered by Lukes (2005) in his three dimensions of power. According to Lukes (2005, p.29), power can be exercised in three dimensions, namely (i) power over decisions, (ii) power over non-decisions, and (iii) power over political agendas. Power over decisions explains how powerful actors influence other actors and control the decision-making process through its resources, such as budget, knowledge, and sanction mechanisms. Power over non-decisions is mainly used by actors equipped with a complete understanding of the decision-making process and knowledge about the inability or limitations of other actors involved in such processes. Powerful actors block others' involvements through, e.g., hiding the meeting agenda, arranging meetings at conflicting times for competitors and dismissing minutes from meeting invitations. Therefore, this second dimension is also called agenda setting. The third dimension of power is potentially used by knowledgeable actors to alter other' interests or even to restrain other' interests as options by creating myths or offering judgments that certain behavior should (not) be preserved (McCabe, 2013). Lukes' three dimensions of power and previous works in which he criticized, e.g., Dahl (1957) and Bachrach and Baratz (1962), are focused on power as domination, widely known as power over (Haugaard, 2012), which may be identified from observable (overt and covert) and latent conflicts (Lukes, 2005: 29). Lukes, however, gives little attention to power to, which refers to power as property, such as power to do something (McCabe, 2013: 52), regardless of whether this power is used.

To fill this hole as well as to address the need for an analytical framework for assessing bureaucratic obstacles in succeeding forestry program, Krott et al. (2014) offer the actor-centered 
power (ACP) approach. This approach has reportedly been successfully tested in Nepal (Devkota, 2010), Indonesia (Maryudi, 2011), Namibia (Schusser, 2013), Germany (Schusser et al., 2013) and Cameroon (Movuh, 2012). Unlike the previous ones, the ACP approach focuses on the power of actors and their potential to create, execute or even block any program posed by themselves or other actors. Krott et al. (2014) define power as a social relationship in which Actor A has the ability to alter the behavior of Actor B without recognizing B's will. In other words, power could be the ability to shape a program according to one's owns interests, even against resistance from other actors. According to Krott et al. (2014), power is empirically observable, explicitly appearing in organizational documents and implicitly detected through actors' interests or acts in maximizing power resources. In this regard, power resources are all capacities owned to implement one's own programs or to alter others' behavior so that they correspond to the interests of the potentate. An increase in power resources will automatically increase the power of the owner, and vice versa, although power resources are not always exercised by the owner.

According to Krott et al. (2014), power consists of three elements and can be ascribed to one actor or can be distributed among several equal actors. The first element, coercion, is defined as altering the behavior of the subordinate by force. In a social relationship, coercive power is associated mainly with bureaucracy, where the people provide the bureaucracy with a mandate through law for it to implement any agreed rules and to reinforce such rules by applying sanctions to those who disobey them. The second element is (dis)incentives, which is defined as advantages or disadvantages introduced to alter the behavior of the subordinate. Authorities could direct others' behavior by introducing a disadvantage, e.g., the revocation of permits for forest concessionaires, for those who fail to perform harvesting operations in an ecologically sound manner. Advantages could also change subordinates' behavior because all actors naturally desire to maximize their benefits. The last element of power is dominant information, which means unverifiable information. Information can be classified as pure information, which can be easily verified by recipients, and selected information, which recipients can verify only with difficulty, or not at all, due to a lack of capacity, lack of will, or lack of simple trust in the information provider. Dominant information becomes an element of power because actors without valid information cannot easily make appropriate decisions. In this context, dominant information includes any information that can be provided only by a state agency and that is needed by other stakeholders. In some cases, the absence of such information for the public due to an 'unwillingness to share' or 'unavailability to share' could be used to increase the bargaining position of the agency responsible for it.

The ACP approach can measure the elements of power that are associated with actors (behaviorism), but it cannot address the structural aspects of power, e.g., of institutions, as can, e.g., the three dimensional model developed by Lukes (2005). The ACP approach fully covers the first dimension of Lukes' power concept. It also covers the second dimension and partially covers the third one. In particular, we are unable to assess, e.g., the hidden agenda of bureaucracies, interests that do not appear in any policy action, and latent conflicts among bureaucracies, but our approach is capable of analyzing the distinct and empirically observable power resources (coercive, incentive and information resources) a specific actor has at hand.

\subsubsection{Absolute and relative gains theorem}

Major political reform in a country always generates consequences affecting one or more players (Vis and Van Kersbergen, 2007), which could result in a zero, negative or positive sum (Uhlaner, 1989). In a positive-sum situation, all players gain benefits from their constructive interaction. However, the initial capability of any player and the amount of absolute/ultimate gain it obtains in cooperation can show which player is the real winner. Halas (2008) compares the absolute gain of an actor with its initial capability to find what he calls the relative gain. The actor with the higher percentage of relative gain is deemed the winner, compared to other actors with lower percentages of relative gains. There are three conditions under which a player can be considered the winner. First, it has lower capability but obtains the same amount of absolute gain as obtained by others. Second, it has similar capability to others but obtains more absolute gain. Lastly, it has a higher capability and obtains more relative gain. The winner, in this context, can be simply illustrated as a younger brother who receives as much money as his older brother from their parents, although the actual money he needs to spend is smaller than the cost of his older brother's needs.

In our studies, we consider initial capability as a whole power source held by any actors, such as budget allocation, number of staff, strategic tasks, and exclusive information, whereas absolute gain refers to strategic tasks. The selection of strategic tasks as single indicator of absolute gain is based on the fact that every task should be equipped by another source of power. Furthermore, we choose status quo as a reference point in measuring the increasing and decreasing power of state agencies, instead of using aspirations, heuristics, analogies and emotion (Mercer, 2005).

\subsection{Case selection and empirical methods}

Indonesia was selected as a study country for three reasons. First, as a developing country, it is very influenced by international actors in terms of gaining financial support from foreign countries and international funding resources. Second, deforestation resulting from the development of forest plantations for pulp, paper and palm oil generates market resistance to those products, which influences the government's other decisions pertaining to forests. Third, the forestry sector is facing heavy pressure from agricultural, mining and plantation sectors, as local governments seek sources of income to fund their local development by converting forests to other more marketable sectors, resulting in intense competition among new and old state agencies.

The reasons mentioned above, along with the actors involved, challenge the power stability of the MoF as the bureaucracy in charge of forests in Indonesia. To study the power dynamics between the MoF and other bureaucracies, we selected two cases from international and national processes that currently are at work in Indonesia, namely, the Norway-Indonesia REDD+ Programme and the One Map Policy. The case selection was based on the fact that both processes involve new cross-cutting issues (e.g., forestclimate, foreign affairs, and multi-sector land use) and both involve new state agencies.

The primary data were policy documents containing tasks assigned to bureaucracies, which were used as indicators of element of power for these bureaucracies (see: Policy documents cited). We also conducted interviews with semi-structured questions to detail or verify these documents, catch up on the most recent facts surrounding the issues, discover more information about the near-future agenda of relevant actors (Schultze and Avital, 2011) and confirm the data or statements from certain actors in the public sphere. The interviews were conducted in Jakarta and Bogor in June-September 2013 and involved 9 persons from environmental organizations, 3 persons from business groups, 11 persons from state agencies and 2 academics (see List of interviewees). Because statements by staff do not necessarily represent the views of agencies, we avoided to put these statements explicitly in our analysis. However, we interpreted their opinions regarding organizational interests that are not written in policy documents as their true thoughts/intentions. 
We also carried out non-participant observations of national conferences to ascertain the actors' positions on selected cases (Gillespie and Michelson, 2011). We also analyzed the content of the minutes from national or international conferences, legal documents and the publications and websites of ministries, state agencies and national and international organizations. Furthermore, we engaged in personal communications with state officials to confirm the data and information up to April 2014.

\section{Results}

\subsection{Historical background}

The Basic Forestry Law of 1967 was employed by the government of Soeharto, who took power a year prior, to designate nearly 120 million hectares of land, or $62 \%$ of Indonesian land, as state forest area without a proper acquisition process (Galudra and Sirait, 2009). Facing very high inflation, a deficit in the state budget, unstable domestic politics, looming external debt and moral crises (Pauker, 1967; Rock, 2003), the government believed that log exports may be the fastest way to gain cash (Barr, 2006). Until 1980, the Ministry of Forestry (MoF) had assigned 43 million hectare of forest to 438 concessionaires (Barr, 2006). A series of policies undertaken by the MoF during the 1980s to the 1990s accumulated forest resources in the hands of some businesses, which enabled them to produce plywood at very low costs. Indonesia accounted for approximately $90 \%$ of tropical plywood trade in 1993 (Ngadiono, 2004).

The strong hegemony of Soeharto's family, military, ruling political party and Chinese-Indonesian conglomerates on Indonesia' forest business (Kaoneka, 1999; Gellert, 2010a) undoubtedly lifted gross domestic product, foreign exchange and government revenue; created jobs and promoted development outside Java (Simangunsong, 2004). However, the vast problems resulting from massive and unsustainable forest extraction were also undeniable and remain unresolved. Some of the most highlighted problems are the rate of deforestation (Hansen et al., 2009), illegal logging (Casson and Obidzinski, 2007), annual fires (Tacconi et al., 2007), a loss of biodiversity (Lenzen et al., 2012) and land use conflicts (Sahide and Giessen, 2015; Fay and Michon, 2005). The MoF has been blamed for these forest problems because its policies have frequently been deemed inconsistent, inaccurate, inadequate and unfair. Other negative attributes attributed to the MoF, such as corruption (Nellemann and Interpol Environmental Crime Programme, 2012), a lack of transparency and data openness (Simangunsong, 2004; Brown, 2002) and limited public participation in decision-making processes (Santosa et al., 2013), have caused the public to lose trust in the MoF.

Momentum for better forest governance grew when Indonesia hosted the thirteenth session of the Conference of the Parties of the United Nations Framework Convention on Climate Change (UNFCCC COP 13) in 2007, where the Bali Road Map, which contains approaches to stimulate a reduction in emissions from deforestation in developing countries, was adopted. To maintain the spirit of the Bali Road Map, strengthen Indonesia's position in international negotiations on climate change and coordinate all related actions dealing with climate change, in 2008, the president of Indonesia established the Dewan Nasional Perubahan Iklim, or DNPI (National Council on Climate Change) (DNPI, 2013). The DNPI was tasked with overseeing the implementation of climate change programs and acting as Indonesia's vocal point on climate change in international forums. One of the acknowledgeable achievements of the DNPI is its success in gaining a 1 billion dollar commitment from Norway for reducing greenhouse gas emissions (REDD) in 2010. Norway-Indonesia cooperation in the next few years will become mainstream for Indonesian policy on forest and environment and affect national development, in addition to many state agencies and local governments. This wave of development in environmentalism was also utilized by the presidential office (UKP4) to synchronize overlapping maps produced by sectoral ministries and reconstruct them into one agreed upon and standardized map. Up to now, both international and national initiatives have largely influenced the role of the MoF in maintaining forest area.

\subsection{Power dynamics in the Norway-Indonesia REDD+ Programme}

The land use change and forestry (LUCF) sectors are the main source of greenhouse gas (GHG) emissions in Indonesia (Harris et al., 2012). Reports produced by the Ministry of Environment (MoE, 2010) and the DNPI and McKinsey (2009) confirm that LUCF contributed approximately $51-85 \%$ of the total $\mathrm{CO}_{2}$-equivalent released between 1994 and 2009, depending on the research methods and parameters used (to compare net emissions from forest areas counted by other bureaucracies, see MoF, 2008). To address this problem and create significant momentum in the reduction of carbon emissions from all development sectors, especially both sectors mentioned, the president of Indonesia announced at the 2009 G-20 meeting that the country intended to reduce its carbon emissions by $26 \%$ by 2020 (Yudhoyono, 2009). Indonesia also welcomed international assistance and increased its rate of carbon reduction to up to $41 \%$. This ambitious pledge then attracted the participation of the Kingdom of Norway, which granted 1 billion USD in financial support, as stated in the agreement signed by both countries in May 2010. Shortly after the announcement was made, environmental NGOs and researchers questioned how Indonesia could reach its target in the midst of the complexity of forest governance at the national level and of numerous unresolved forestland conflicts in Sumatra and Kalimantan. Other questions that arose in several discussions were what scientific reasoning was the basis for this pledge and who organized it (Resosudarmo et al., 2013).

In April 2009, the DNPI, in cooperation with McKinsey, evaluated the potential reduction of carbon emissions from eight major sectors, namely land use, land use change and forestry (LULUCF), peatland, agriculture, power, transportation, petroleum and gas, cement and buildings. An interim report on this study was issued in September 2009, and the final report was issued in June 2010. The interim report stated that the projection for Indonesian emissions in 2020 would be $2820 \mathrm{GtCO} 2 \mathrm{e}, 71 \%$ of it from the forestry and peatland sectors (DNPI and McKinsey, 2009). However, the final report of this study reveals that Indonesian emissions in 2020 are estimated to be $2530 \mathrm{GtCO} 2 \mathrm{e}$, with the share attributed to LULUCF and peat reaching $64 \%$, or $10 \%$ below the levels in the previous interim report (DNPI and McKinsey, 2010). The president's commitment to Indonesia's GHG emissions reduction, as he again stated in the 2009 COP15 in Copenhagen, was most likely based on the interim report on this study because other options were unavailable.

In addition, beginning in 2008 , the $\mathrm{MoE}$, as an Indonesian focal point for the United Nations Framework Convention on Climate Change (UNFCCC) (replaced by the DNPI in 2008), began conducting a national greenhouse gas inventory to fulfill Indonesia's Second National Communication to the UNFCCC. A summary of this work became available to the public in November 2009, and the complete report was published in November 2010 (MoE, 2009, 2010). Both reports consistently projected that Indonesia's net emissions under a "business as usual" (BAU, without mitigation policy) scenario would be approximately 2950 GtCO2e by 2020 (MoE, 2009, 2010). This 2-year study did not 
Table 1

Targets in emissions reductions by 2020 by each corresponding bureaucracy (in MtCO2e).

\begin{tabular}{|c|c|c|c|c|c|c|c|c|c|c|c|c|}
\hline \multirow[t]{2}{*}{ Sector } & \multicolumn{12}{|c|}{ Responsible bureaucracy } \\
\hline & MoPW & MoA & MoF & MioEMR & MoTrans & $\mathrm{MoFi}^{\mathrm{a}}$ & $\operatorname{MoSE}^{\mathrm{a}}$ & $\begin{array}{l}\text { Jakarta } \\
\text { province }^{a}\end{array}$ & $\begin{array}{l}\text { Ministry of } \\
\text { industry }\end{array}$ & $\begin{array}{l}\text { Target until } \\
2014\end{array}$ & $\begin{array}{l}\text { Target } \\
2015-2020\end{array}$ & $\begin{array}{l}\text { Total target } \\
2010-2020\end{array}$ \\
\hline Agriculture & 0.2 & 130.6 & & & & & & & & 130.7 & 0 & 131 \\
\hline Forestry and peat & 5.2 & 204.7 & 600.7 & & & & & & & 810.7 & 62.4 & 873 \\
\hline Energy and Transport. & 1.1 & & & 12.5 & 40.0 & 0.0 & 0.0 & 11.1 & & 53.6 & 47 & 100 \\
\hline Industry & 0.0 & & & & & & & & 3.8 & 3.8 & 5.3 & 9 \\
\hline Waste Management & 19.2 & & & & & & & & & 19.2 & 47.2 & 66 \\
\hline Total & 25.7 & 335.3 & 600.7 & 12.5 & 40.0 & 0.0 & 0.0 & 11.1 & 3.8 & 1018.0 & 161.7 & 1180 \\
\hline
\end{tabular}

Source: Presidential Regulation No 61/2011 (calculated).

a Joint program with the Ministry of Transportation.

address the president's commitment to national emissions reductions.

Following the president's commitment, and considering studies conducted by the DNPI \& McKinsey and the MoE, BAPPENAS ${ }^{2}$ drew up an academic paper on the national action plan for greenhouse gas emissions reductions, which then was enacted as a presidential regulation (Perpres) 61/2011 in September 2011. BAPPENAS fully adopted and only used the study by the MoE to distribute emissions reduction targets to each sector and the corresponding ministry/agency responsible for each. However, the agency indicated to each sector before the Perpres was issued that it was not the single agency responsible for that sector, according to the Perpres. In the forestry and peat land sectors, for instance, the MoF has the responsibility of reducing carbon emissions by $74 \%$, whereas the MoA and the Ministry of Public Works (MoPW) are assigned $25 \%$ and $1 \%$ of the target, respectively (Table 1 ). BAPPENAS is also in an important position, holding the authority, according to Perpres 61, to create guidelines for reporting the Regional Action Plans for Greenhouse Gas Emission Reduction (RAD-GRK), facilitating provincial governments to make RAD-GRKs, archiving them and reviewing and revising RAN-GRKs in accordance to national needs and developments in international dynamics. It appears that BAPPENAS has tried to be the leading agency in the greenhouse gas issue (interviewees 19 and 24).

The Norway-Indonesia Letter of Intent/LoI (The Government of the Kingdom of Norway and the Government of the Republic of Indonesia, 2010) requires the government of Indonesia to establish a special agency in addition to and in competition with the MoF tasked with (i) reporting the progress of the REDD+ Programme and activities to the president, (ii) completing the REDD+ national strategy, (iii) preparing a measurement, reporting and verification (MRV) institution, (iv) designing funding instruments and (v) selecting a pilot province for REDD+ activities. These works have been carried out completely by the REDD+ Task Force, a new agency under UKP4 formed by Presidential Decree (Kepres) No. 19/2010 (Santosa et al., 2013; President of Indonesia, 2010). In addition, the Task Force also successfully passed 'the first forest and peatland moratorium by presidential instruction in 2011 (President of Indonesia, 2011). In August 2013, the president established the REDD+ Agency and appointed the Deputy of UKP4 as its head. This appointment brought climate change business, especially all REDD+-related programs, back to the people of UKP4.

In this stage, three intersectoral bureaucracies have risen and head other bureaucracies through new regulations proposed themselves. In particular, the DNPI has its climate change policy, BAPPENAS has its national action plan for greenhouse gas emissions reduction (RAN-GRK) and the REDD+ Agency has its REDD+

\footnotetext{
2 BAPPENAS is a state agency in charge of designing and synchronizing the national development agenda.
}

Programme. The climate change issue, of course, is more widely discussed at an international level than greenhouse emissions reduction and the REDD+ Programme. Thus, the DNPI represents Indonesia in many international negotiations. Furthermore, because the DNPI is close to the president, any national policy on climate change is more easily shaped ${ }^{3}$ (interviewees 15,22 and 25). The REDD+ Agency and BAPPENAS, in contrast, work in more domestic areas by coordinating other ministries, agencies and local governments to carry out their assigned tasks and by having them report their achievements periodically.

Accordingly, the power element of state agencies in the REDD+ Programme and its related policy is distributed among seven state agencies, most of which are concentrated at the two new agencies, i.e., the DNPI and the REDD+ Agency (Table 2). The MoF and the MoA, institutionally, have no significant mandate in shaping any policy within the REDD+ Programme, although they are members of the REDD+ Agency and have the highest reduction target for emissions from forest and peatland. Instead, their staffs have to serve other bureaucracies for this program to succeed.

\subsection{Power dynamics in the Indonesian One Map Policy}

One of the prolonged and still unresolved problems in Indonesian forest governance is the obscurity of land and forest boundaries that is induced by the presence of multiple and overlapping maps made by bureaucracies that are closely associated to land resource use, namely, MoF, MoA, the Ministry of Energy and Mineral Resource (MoEMR) and the National Land Agency (BPN). This issue is due to the absence of a single reference for a geospatial information service used jointly by the ministries, the lack of a generally accepted standard on thematic maps and the need for an agency explicitly charged with compiling and integrating those maps.

The idea of having one standardized map for all of Indonesia came from UKP4, when they persuaded the president by showing differences in maps made by the MoF and the MoE and the implications at the Cabinet Meeting on 23 December 2010 (REDDMonitor, 2012). At the time, the president said, "(there) should be one authoritative map for national reference" (Samadhi, 2013). This policy is actually in line with Indonesia's commitment to a logging moratorium on forests and peatland, as stated in the Norway-Indonesia LoI. A Moratorium Map could be a good example of a single and integrated map over a designated area. To realize the policy, UKP4, together with the corresponding ministries and agencies, held a series of discussions defining the authority for each thematic map, constructing a standard for thematic maps and agreeing to it being used as a joint reference. For example, they agreed to refer to the MoA for peatland standards while approving

\footnotetext{
3 DNPI's closeness to the President was revealed by Purnomo (2012), a Special
} Staff to the President for Climate Change and Head of the DNPI Secretariat. 
Table 2

Dynamics of power elements in the Norway-Indonesia REDD+ Programme.

\begin{tabular}{|c|c|c|c|c|c|c|c|c|}
\hline Power element & Strategic task & $\mathrm{MoF}$ & $\begin{array}{l}\text { UKP4 (REDD+ } \\
\text { Task Force) }\end{array}$ & DNPI & REDD+ Agency & $\mathrm{MoE}$ & MoA & BAPPENAS \\
\hline \multirow{13}{*}{$\begin{array}{l}\text { Coercion } \\
\text { (Dis)-incentive }\end{array}$} & - & & & & & & & \\
\hline & Developing REDD+ national strategy & & + & & & & & \\
\hline & Shaping forest and peat moratorium policy & & + & & & & & \\
\hline & Improving REDD+ national strategy & & & & + & & & \\
\hline & $\begin{array}{l}\text { Mainstreaming REDD+ in national } \\
\text { development agenda }\end{array}$ & & & & + & & & + \\
\hline & Managing REDD+ funding & & & & + & & & \\
\hline & $\begin{array}{l}\text { Shaping Indonesia's position in } \\
\text { international REDD+ fora }\end{array}$ & & & & + & & & \\
\hline & $\begin{array}{l}\text { Supervising and evaluating } \\
\text { implementation of REDD+ Programme }\end{array}$ & & & & + & & & \\
\hline & $\begin{array}{l}\text { Forming national strategy on climate } \\
\text { change }\end{array}$ & & & + & & & & \\
\hline & $\begin{array}{l}\text { Coordinating activities related to climate } \\
\text { change }\end{array}$ & & & + & & & & \\
\hline & $\begin{array}{l}\text { Monitoring and evaluating } \\
\text { implementation of climate-change-related } \\
\text { policy }\end{array}$ & & & + & & & & \\
\hline & Reviewing and adjusting RAN-GRK & & & & & & & + \\
\hline & $\begin{array}{l}\text { Developing guideline for RAD-GRK } \\
\text { reporting }\end{array}$ & & & & & & & + \\
\hline \multirow[t]{7}{*}{ Dominant information } & Representing Indonesia at the UNFCCC & & & + & & - & & \\
\hline & Negotiating the Norway-Indonesia LoI & & & + & & & & \\
\hline & $\begin{array}{l}\text { Establishing standard for emission } \\
\text { measurement }\end{array}$ & & & & + & & & \\
\hline & $\begin{array}{l}\text { Archiving implementation report for } \\
\text { RAN-GRK and RAD-GRK }\end{array}$ & & & & & & & + \\
\hline & Conducting GHG inventory & & & + & & + & & \\
\hline & Providing staff on the ground & + & & & & & + & \\
\hline & $\begin{array}{l}\text { Providing concrete forest-related } \\
\text { information }\end{array}$ & + & & & & & & \\
\hline
\end{tabular}

Note:

(+) Gaining power resource(s) regarding the specific power elements due to the assignment of the strategic task to specific state agency.

$(-)$ Losing power resource(s) regarding the specific power elements due to the assignment of the strategic task to specific state agency.

RAN-GRK National Action Plan for Greenhouse Gas Emissions Reduction.

RAD-GRK Regional Action Plan for Greenhouse Gas Emissions Reduction.

the forestland cover criterion set by the MoF. All accepted standards then have to be listed in the Indonesian National Standard Directory.

In May 2011, the government passed the Presidential Instruction (Inpres) No 11/2011 on the postponement of the issuance of new licenses and improving governance of primary natural forests and peatland, with special instruction to the MoE to reduce gas emissions by improving business governance within forests and peatland areas in an associated map. The Inpres 11/2011 came up with a new interpretation of the 1999 Forest Law (Government of Indonesia, 1999) by specifying the MoE as "the agency that is responsible for the governance of forest and peatland under the Moratorium Map" rather than the MoF, which traditionally represents "the government" that rules forest resources. The president also tasked the MoF, together with BIG, BPN and the REDD+ Agency, with half-yearly updates on the forest and peatland cover map. As the instruction opens for public input, the Directorate General of Forest Planning of the MoF will situate itself as a repository for public feedback (MoF, n.d.). If the proposal is complete, the ministry will approve and accommodate it in the next revised map. UKP4, BIG, BPN, the MoA and academics will engage in the process only if the proposal requires ground verification. A coordinated meeting of the six agencies/ministries will then decide to include or exclude such proposed amendments in the next moratorium map.

\subsubsection{Thematic maps}

The One Map Policy launched by UKP4 is beyond the moratorium map, which covers only approximately 69 million hectares of forest and peatland (Sloan, 2014). The One Map Policy is a coordinated and integrated mapping program for the whole country involving 12 working groups from 18 ministries/agencies, covering watershed management, space management, land conditions, forest cover, climate change risks, ecoregions, disasters, transportation, national defense and intelligence, cultural heritage, economics, and many other topics. Based on the Agreement Document of the National Coordination Meeting for Geospatial Information 2013, the ministries/agencies within the groups will spend nearly USD 70 million for the 2014 thematic geospatial information service from their own annual budget allocated for a mapping program (Table 3 ). The MoF alone will spend $31 \%$ of all budgets (the largest budget) to produce $11 \%$ of the thematic maps, whereas another 10 ministries and agencies with smaller mapping budgets will spend only $15 \%$ of their budgets to produce $30 \%$ of the thematic maps. Thus, although the MoF's power is diminished in the case of the moratorium map issue, it still manages much of the data on forest resources and has a strategic position in negotiations on forest resources.

Though the One Map Policy is expected to overcome the land conflict problem, it seems that there will be a long process to achieve its goal. The MoF, MoA and MoE will produce different and similar thematic maps on the same forest and land areas, as agreed upon in the document on the National Coordination Meeting. Thematic maps that overlap may give rise to conflicting interests. In addition, the MoA and MoEMR, based on Presidential Instruction $10 / 2011$, have the authority to utilize areas under the moratorium map for vitally important national projects, e.g., those involving electricity, geothermal energy, oil and gas, and paddy and sugarcane fields. Therefore, an overlap between those interests is difficult to avoid. 
Table 3

Budgets of the 7 main state agencies for geospatial information services in 2014

\begin{tabular}{|c|c|c|c|}
\hline Ministry/agency & Number of map themes & Expenses for geospatial information service (USD) ${ }^{\mathrm{a}}$ & $\%$ of total spending \\
\hline Ministry of Forestry & 26 & 21,345 & $31 \%$ \\
\hline Geospatial Information Agency & 43 & 10,684 & $15 \%$ \\
\hline Ministry of Energy and Mineral Resource & 29 & 9402 & $14 \%$ \\
\hline National Land Agency & 5 & 6188 & $9 \%$ \\
\hline Ministry of Marine Affairs and Fisheries & 10 & 4025 & $6 \%$ \\
\hline Ministry of Agriculture & 20 & 3769 & $5 \%$ \\
\hline Ministry of Energy & 22 & 3474 & $5 \%$ \\
\hline Other 11 ministries/agencies & 66 & 10,620 & $15 \%$ \\
\hline
\end{tabular}

Source: BIG (2013).

a The exchange rate for 1 USD is $11,700.00$ IDR.

Table 4

Dynamics of power elements in the Indonesian One Map policy.

\begin{tabular}{|c|c|c|c|c|c|c|c|c|}
\hline Power element & Strategic task & $\mathrm{MoF}$ & UKP4 & BIG & REDD+ Agency & MoE & MoA & MoEMR \\
\hline \multirow[t]{2}{*}{ Coercion } & $\begin{array}{l}\text { Postponing business license over primary forest and } \\
\text { peat land }\end{array}$ & - & + & & & & & \\
\hline & $\begin{array}{l}\text { Taking responsibility for primary forest and peat land } \\
\text { within moratorium map }\end{array}$ & - & & & & + & & \\
\hline \multirow{4}{*}{$\begin{array}{l}\text { (Dis)- } \\
\text { incentive }\end{array}$} & Employing own staff for One Map Policy & - & + & - & + & & - & - \\
\hline & Acting as leading agency on One Map Policy & & + & & & & & \\
\hline & Acting as coordinator of technical aspects & - & & + & & & & \\
\hline & Spending much of budget for thematic maps & + & & & & & & \\
\hline \multirow{3}{*}{$\begin{array}{l}\text { Dominant } \\
\text { information }\end{array}$} & Joint updating of moratorium map twice per year & + & & + & & & & \\
\hline & Producing thematic maps & + & & + & & + & + & + \\
\hline & $\begin{array}{l}\text { Taking responsibility for public feedback on the } \\
\text { moratorium map }\end{array}$ & + & & & & & & \\
\hline
\end{tabular}

Note:

(+) Gaining power resource(s) regarding the specific power elements due to the assignment of the strategic task to specific state agency.

(-) Losing power resource(s) regarding the specific power elements due to the assignment of the strategic task to specific state agency.

Until 2005, the MoF kept 16 thematic maps to itself, and only some parties could access them. Today, the Ministry has the authority to release 29 thematic maps (layers), of which 17 are open to the public and 12 are still secured (Rahayu, 2013). Although there is a noticeable increase in the number of maps produced, the number of maps available to the public is quite constant. A respondent informed us that there is no regulation that would make all maps available to the public. From the bureaucratic politics perspective, a series of political regulations surrounding this topic has been reducing the power of the MoF, in the sense that the Ministry should share a part of the authority. Table 4 shows the power dynamics of the MoF and other bureaucracies that benefit from this policy.

\section{Discussion and conclusions}

\subsection{The Ministry of Forestry under threat?}

Both of the observed processes occur in light of international influences aimed at changing forest-related policy in Indonesia (Nurrochmat et al., 2014). According to Bernstein and Cashore (2012) the REDD+ case may be considered one form of direct access to domestic policy making, whereas with the One Map Policy, this type of relation with international actors and institutions is less clear. Still, both cases suggest, to a reasonable extent, that in addition to the constant threats from domestic bureaucracies, it may be international influences, in particular, that challenge the established power sources of forest bureaucracies (Burns and Giessen, 2015; Ongolo, 2015; Mbatu, 2015; Ojha et al., 2009). This may be interpreted as a strategy that international actors use to circumvent an overly powerful and corrupt MoF, acting in coalition with its rival domestic bureaucracies but potentially incurring losses, e.g., critical information on forests. Thus, it does seem that international influences, in coalition with other domestic bureaucracies, attempt to reduce the power of the MoF, with limited success, as our results suggest.

\subsection{Declining relative power of the Ministry of Forestry?}

The relative power of the MoF declined in the cases observed, mainly because its responsibilities and related tasks have been gradually replaced or shared with other state agencies. The UKP4, DNPI and REDD+ Agency are the new bureaucracies gaining both relative and absolute power (similar Sahide and Giessen, 2015), especially through the international influences created by the Norway-Indonesia REDD+ Programme, which began in 2010. A logging moratorium on virgin forests and peat areas since 2011 provides an impetus to improve forest governance in many aspects, such as policy and regulation harmonization, forest area gazettal acceleration and land conflict resolution, enabling other bureaucracies (MoEMr, MoA, MoPW, MoE, MoDA, MoFi, BPN, BIG, BAPPENAS, MoLHR, and National Commission on Human Rights) to participate in forest governance (KPK, 2013). These agencies apparently do not fully assume the tasks of the MoF; rather, they are in charge of some complementary work to help the ministry improve forest governance. However, with approximately $50 \%$ of the emissions reduction target assigned to the $\mathrm{MoF}$ and $28 \%$ to the MoA (see Table 1), and with very limited authority to shape the policy on this issue, it is sound to argue that both ministries have been losing parts of their power over their original domain. Something similar has happened with the One Map Policy, as the UKP4 and the BIG take the "incentive element of power" from the ministry and leave the "informational resource element". In general, the agencies that gain notably in power at the expense of the MoF in both cases are the UKP4, REDD+ Agency, the MoA, and the MoE. The DNPI and BAPPENAS gain power slightly through the REDD+ Programme, whereas the BIG and the MoEMR gain it through the One Map Policy. Thus, in the selected cases, a decrease in the power of the MoF is observed. 
Although it loses much relative power in the two cases observed above, the MoF may still gain power in other fields, marked, among other things, by the increase in annual budget allocations and the number of staff (similar Brockhaus et al., 2012, 2014). According to its own information (MoF, 2013), the MoF's overall budget allocation in 2009 was IDR 2.8 billion. This doubled to IDR 5.7 billion in 2012 , with the average spending realization reaching approximately $84 \%$. In addition, its staff increased slightly, from 14,234 people in 2001 to 17,521 in 2011, a 2.1\% growth (MoF statistics data, various years), whereas the global trend for the number of people who work in public forest bureaucracies is a decrease of $1.2 \%$ annually (FAO, 2010). These numbers appear to contradict our results. In fact, these findings imply that, outside of the MoF's loss of incentive and coercion power in the observed cases and in the recent constitutional court decision on "state forest areas" (Sahide and Giessen, 2015), it has done very well in maintaining and even increasing its overall power in many other fields. Combining our results with these alternative explanations suggests that it is the MoF's power source of dominant information in particular that remains with the MoF across cases. Such information includes that on the legal aspects of forestry, the physical dimensions of forests, existing logging rights and other competing land use concessions and site conditions regarding growth potentials and degradation (Sahide and Giessen, 2015). Consequently, the MoF remains an indispensable partner for all other agencies wanting to become active in forest-related issues. In this way, discrete, non-verifiable information enables an actor to attract additional staff and budget funds, adding to its incentive power in absolute terms (Hasanagas, 2014). This suggests that the power element of dominant information is a necessary precondition for the build-up and maintenance of incentive and coercive power and can be seen as the last bastion in bureaucratic power struggles, a potential thesis for future research.

\subsection{REDD+ doomed to remain symbolic?}

In light of our results, Indonesia's emission reduction effort is likely to remain a symbolic policy only. We now more clearly define symbolic policy in the sense of a non-policy, which, besides formulating goals and instruments, is not equipped with clear responsibility in terms of implementing agencies, sufficient staff, budget resources and necessary information (Krott et al., 1990; Krause, 2011; Edelman, 1977; and similar to non-decision making by Bachrach and Baratz, $1962^{4}$ ). The two observed cases, we conclude, are based on weak legal constructions, have no single strong leading agency responsible for ensuring continuity and have only weak long-term agendas with no stand-alone budgets or discrete staff. First, the REDD+ Programme and instructions about the logging moratorium were merely a policy at the presidential level and did not involve parliament as a representative of the majority of the nation (Luttrell et al., 2013). An amendment of presidential instruction or regulation is relatively easy, and it is possible to carry out as the president wants. Indeed, the instructions about the logging moratorium will automatically become invalid by May 2015, as it is only applicable for 2 years after its first extension. Both the policy and the program will end without any additional intervention from the president. ${ }^{5}$ Second, the emissions reduction target was set by the DNPI, the existence of which strongly depends on the new president's commitment. In fact, the elected president has placed the DNPI under the newly formed Ministry of Environment and

\footnotetext{
4 Edelman (1977, cited by Boussaguet, 2015) expressed symbolic policy as ‘words that succeed and policies that fail'.

5 The President finally extended the logging moratorium for the third 2 years through Inpres 8/2015 (President of Indonesia, 2015b).
}

Forestry; therefore, there is no longer a specific agency responsible for the promised emissions reduction target. If real effects on the ground are intended by means of REDD+, the presence of a permanent and powerful agency is important (Brockhaus et al., 2014); otherwise, the policy will remain merely symbolic, without appropriate information and means (e.g., staff and budget) for implementation (Sadath and Krott, 2012). Third, the opportunity to use the primary forest and peat area covered by the moratorium map for other purposes indicates that this policy has been designed more with business (production) interests in mind, rather than an ideological base, and signals that the government intends to reassign the moratorium area to another purpose as it sees fit. We conclude that, as long as no public agency has clear responsibilities for policy formulation and implementation, sufficient regulatory or incentive instruments and the best possible forest-related information, REDD+ efforts are doomed to remain a symbolic policy only (similar Irawan et al., 2014). Such a symbolic policy of course can be very useful for pooling donor funds at national level, without dedicating (further) staff and budgetary resources to the policy, leading to more or less discrete funds resting with the bureaucracy in charge.

\subsection{Bureaucratic challenges in implementing the REDD+ Programme}

Since its inception, the REDD+ policy has provoked controversy as to which ministry will take the lead in framing the agenda and supervising its implementation. The option to establish the REDD+ Agency as an institution coordinating all REDD+-related activities made implementation of the REDD+ Programme run roughly. Some analysts (e.g., Hogl et al., 2009; Mulyani and Jepson, 2013; Dermawan et al., 2011; Resosudarmo et al., 2013) have already warned that creating new state agencies to oversee climate change issues, including emissions reductions through the REDD+ Programme, will raise significant bureaucratic conflicts, e.g., difficulties in coordination, a lack of capacity, a low budget, risk of corruption and an uncertain policy direction. This claim was evidenced by Moeliono et al. (2014), who revealed that the most influential actors in the REDD+ Programme in Indonesia tended to not seek or obtain information from other actors and that the information exchange between them was weak. This dearth of information exchange indicates that each bureaucracy does not want to open its agenda regarding policy formulation and will expose it to the public only when it is complete. Asking for dominant information from opponent bureaucracies can raise an organization's bargaining position and give it material to prepare an opposing agenda, one likely to harm the original agenda. This problem exists whenever there are many bureaucracies with similar assignments and balanced levels of power (Sulistiawati, 2013) and serves as an explanation as to why any bureaucracy might abruptly issue an unpredicted decision without consulting others.

\subsection{Sectoral interests hindering an integrated One Map Policy?}

The aim of the One Map Policy is technically achievable, and the process still seems to run as planned without any significant obstacles. The integration process of the forthcoming maps, however, will be the most crucial phase, and needs to be synchronized through a national consensus, as an adjustment of Provincial Spatial Planning (Rencana Tata Ruang Wilayah Provinsi or RTRWP) and Forest Land Use by Consensus (Tata Guna Hutan Kesepakatan or TGHK) (Wardojo and Masripatin, 2002). This future integration process poses major political obstacles, given the observed bureaucratic politics and conflicts of interest of the different state agencies involved. In addition, the literature on policy integration 
suggests that the policy sectors, i.e., the societal clientele and sectoral institutions surrounding these very bureaucracies, intensify these conflicts (comp. Hogl et al., 2009; Briassoulis, 2005; Hubo and Krott, 2013; Giessen, 2012; Giessen et al., 2013; Rayner et al., 2001; Krott and Hasanagas, 2006). In our case, the RTRWP provides a robust legal base for the provincial governments to manage "areas under their authority", whereas the TGHK legalizes the designation of such forest areas and places them under the supervision of the MoF. Unfinished RTRWP-TGHK synchronization has resulted in uncertain land use policy planning and obstructed local development agendas because acting against overriding regulation is a crime (ICW, 2013). The synchronization process, however, will confront the production-oriented sectors, such as logging, plantation and mining, against the conservation-oriented bureaucracies and sectors, including protected forests, conservation forests and high conservation value forests. The production-oriented sectors and extractive regimes (Gellert, 2010b) were found to prevail over their adversaries frequently because they were able to use many unclear, inconsistent and contradictory laws and regulations, exploiting them to promote their interests (Kartodihardjo and Nagara, 2014; Hapsari, 2011). In addition, they have strong supporting bureaucracies and involve large-conglomerate private actors. Such extractive regimes, which characterize recent Indonesian (local) development approaches (Gellert, 2010b), could also be a real challenge for the realization of the green (pro-environmental) development programs proclaimed by the central government. However, the MoF can also obstruct this process by denying approval for spatial planning proposals submitted by provinces and municipalities (Santosa et al., 2013). In addition to the conflictive bureaucratic and sectoral interests at the national level, this latter point adds multi-level conflicts of bureaucratic interest (Marks, 1996; Giessen, 2010; Juerges and Newig, 2015). Hence, even though the One Map Policy seems technically achievable and is expected to be the basis and reference for multi-sector development planning, it is obviously riddled with multiple sectoral conflicts of interest from local and national agendas. Consequently, it is likely to merely become a symbolic policy.

\subsection{Results in light of recent developments}

Our analysis on power elements between the MoF and other state agencies related to the REDD+ Programme and the One Map Policy shows that President Yudhoyono, through his regulations and instructions, had reduced the relative power of the MoF by transferring its power to other state agencies and creating new ones to intervene in forest policy (i.e., UKP4, the DNPI and the REDD+ Agency). Other bureaucracies have found that this new balance is better for forest governance and attempted to extend their influence. However, in January 2015, the new president, Joko Widodo, interrupted this governance by disbanding the DNPI and the REDD+ Agency, together with their information, incentive and coercive power resources, by reassigning their tasks to the new Ministry of Environment and Forestry (MoEF), after dissolving the UKP4 in December 2014 (President of Indonesia, 2014, 2015a). Hence, the dispersed and newly created power elements related to forest governance are now re-centered within the MoEF. The MoEF is in the process of reclaiming $17(77 \%)$ and $10(75 \%)$ of its relative power elements, compared to its initial $2(9 \%)$ and $4(27 \%)$ relative power elements in the REDD+ Programme and the One Map Policy, respectively. As a result, the absolute power of the MoEF in 2015 is larger than that of the MoF in 2014. For any practical purpose, there is currently no significant bureaucratic counterforce that could stop forest policies endorsed by the MoEF, which will lead to a situation similar to the MoF prior to the REDD+ era.

\section{Acknowledgements}

The authors thank Prof. Max Krott and two anonymous reviewers for their valuable comments on earlier drafts of this article and all individuals interviewed for their information and documents. We gratefully acknowledge the support from the German Academic Exchange Service (DAAD), the Eva Mayr-Stihl Foundation, the German Research Foundation (PAK 813) and the Indonesian Directorate General of Higher Education (DIKTI).

\section{List of interviewees.}

\begin{tabular}{|c|c|c|}
\hline Interviewee & Affiliation & Date \\
\hline Interviewee 1 & $\begin{array}{l}\text { Communication Forum for Forest } \\
\text { Community (FKKM) }\end{array}$ & 15.06 .2013 \\
\hline Interviewee 2 & $\begin{array}{l}\text { Indonesian Forum for the Environment } \\
\text { (Walhi) }\end{array}$ & 17.07.2013 \\
\hline Interviewee 3 & $\begin{array}{l}\text { The Alliance of Indigenous People in } \\
\text { Nusantara (AMAN) }\end{array}$ & 29.08.2013 \\
\hline Interviewee 4 & $\begin{array}{l}\text { The Networking for Participative } \\
\text { Mapping (JKPP) }\end{array}$ & 30.08 .2013 \\
\hline Interviewee 5 & $\begin{array}{l}\text { Consortium for Supporting Community } \\
\text { Based Forests (KpSHK) }\end{array}$ & 22.06.2013 \\
\hline Interviewee 6 & $\begin{array}{l}\text { Association for Community and } \\
\text { Ecology Law Reform (HuMa) }\end{array}$ & 22.08.2013 \\
\hline Interviewee 7 & Greenpeace Indonesia & 02.07.2013 \\
\hline Interviewee 8 & Forest Watch Indonesia (FWI) & 20.07 .2013 \\
\hline Interviewee 9 & Sawit Watch & 23.07.2013 \\
\hline Interviewee 10 & $\begin{array}{l}\text { Indonesian Woodworking Association } \\
\text { (ISWA), }\end{array}$ & 22.09.2013 \\
\hline Interviewee 11 & $\begin{array}{l}\text { Indonesian Palm Oil Association } \\
\text { (GAPKI) }\end{array}$ & 28.08.2013 \\
\hline Interviewee 12 & $\begin{array}{l}\text { Indonesian Forest Concessionaires } \\
\text { Association (APHI) }\end{array}$ & 09.09 .2013 \\
\hline Interviewee 13 & Ministry of Forestry & 30.08 .2013 \\
\hline Interviewee 14 & Ministry of Forestry & 19.08 .2013 \\
\hline Interviewee 15 & Ministry of Forestry & 20.09 .2013 \\
\hline Interviewee 16 & Ministry of Forestry & 20.09 .2013 \\
\hline Interviewee 17 & UKP4 & 02.09 .2013 \\
\hline Interviewee 18 & Ministry of Agriculture & 21.08 .2013 \\
\hline Interviewee 19 & Ministry of Finance & 05.09 .2013 \\
\hline Interviewee 20 & Ministry of Trade & 04.09 .2013 \\
\hline Interviewee 21 & $\begin{array}{l}\text { National Council on Climate Change } \\
\text { (DNPI) }\end{array}$ & 03.09.2013 \\
\hline Interviewee 22 & National Land Agency (BPN) & 08.09 .2013 \\
\hline Interviewee 23 & Geospatial Information Agency (BIG) & 18.09 .2013 \\
\hline Interviewee 24 & Bogor Agricultural University (IPB) & 10.09 .2013 \\
\hline Interviewee 25 & Bogor Agricultural University (IPB) & 20.09 .2013 \\
\hline
\end{tabular}

\section{References}

Aurenhammer, P., 2012. Development Cooperation Policy in Forestry from an Analytical Perspective, 13. Springer Science \& Business Media.

Aurenhammer, P.K., Thesis (PhD) 2011. European States' Bilateral Foreign Aid Policy in Forestry, a Policy Field Analyses of Austrian, Finnish, German and Swedish Forestry Aid, with Emphasis on Program Formulation and Implementation. University of Goettingen.

Bachrach, P., Baratz, M.S., 1962. Two faces of power. APSR 56 (04), 947-952.

Barr, C., 2006. Forest administration and forestry sector development prior to 1998 In: Barr, C., Resosudarmo, I.A.P., Dermawan, A., McCarthy, J. (Eds.), Decentralization of Forest Administration in Indonesia: Implications for Forest Sustainability, Economic Development and Community Livelihoods. CIFOR, Bogor, Indonesia.

Bennett, R., Rajabifard, A., Williamson, I., Wallace, J., 2012. On the need for national land administration infrastructures. Land Use Policy 29 (1), 208-219.

Bennett, R., Tambuwala, N., Rajabifard, A., Wallace, J., Williamson, I., 2013. On recognizing land administration as critical, public good infrastructure. Land Use Policy 30 (1), 84-93.

Bernstein, S., Cashore, B., 2012. Complex global governance and domestic policies: four pathways of influence. Int. Aff. 88 (3), 585-604.

Biermann, F., 2010. Beyond the intergovernmental regime: recent trends in global carbon governance. Curr. Opin. Environ. Sustain. 2 (4), 284-288.

Biermann, F., Siebenhüner, B., Bauer, S., Busch, P.O., Campe, S., Dingwerth, K. Tarradell, M., 2009. Studying the influence of international bureaucracies: a conceptual framework. In: Biermann, F., Siebenhüner, B. (Eds.), Managers of Global Change: The Influence of International Environmental Bureaucracies. , pp. 37-76.

Biermann, F., Pattberg, P.H. (Eds.), 2012. Global environmental governance reconsidered. MIT Press. 
Blais, A., Dion, S., 1990. Are bureaucrats budget maximizers? The Niskanen model \& its critics. Polity, 655-674.

Boussaguet, L., 2015. Participatory mechanisms as symbolic policy instruments? Comp. Eur. Polit., http://dx.doi.org/10.1057/cep.2015.12

Briassoulis, H., 2005. Policy Integration for Complex Environmental Problems - The Example of Mediterranean Desertification. Ashgate, Burlington.

Brockhaus, M., Di Gregorio, M., Mardiah, S., 2014. Governing the design of national REDD+: an analysis of the power of agency. For. Policy Econ. 49, 23-33.

Brockhaus, M., Obidzinski, K., Dermawan, A., Laumonier, Y., Luttrell, C., 2012. An overview of forest and land allocation policies in Indonesia: is the current framework sufficient to meet the needs of REDD+? For. Policy Econ. 18, 30-37.

Brown, D.W., 1999. Addicted to rent: corporate and spatial distribution of forest resources in indonesia: implications for forest sustainability and government policy. In: Indonesia-UK Tropical Forest Management Programme, Provincial Forest Management Programme.

Brown, D.W., 2002. Secrecy in the Indonesian forest products sector: a researcher's experience. In: Indonesia, F.W., Watch, G.F. (Eds.), The State of the Forest: Indonesia. Forest Watch Indonesia, Bogor, Indonesia, and Global Forest Watch, Washington DC, pp. 79-80.

Buijs, A., Mattijssen, T., Arts, B., 2014. The man, the administration and the counterdiscourse: an analysis of the sudden turn in Dutch nature conservation policy. Land Use Policy 38, 676-684.

Burns, S., Giessen, L., 2015. Dismantling comprehensive forest bureaucracies: direct access, the World Bank, agricultural interests, and neoliberal administrative reform of forest policy in Argentina. Soc. Nat. Res. (forthcoming).

Casson, A., Obidzinski, K., 2007. From new order to regional autonomy: shifting dynamics of illegal logging in Kalimantan, Indonesia. In: Illegal Logging: Law Enforcement, Livelihoods and the Timber Trade., pp. 43-68.

Dahl, R.A., 1957. The concept of power. Behav. Sci. 2 (3), 201-215.

Devkota, R.R., 2010. Interests and Power as Drivers Of Community Forestry: A Case Study of Nepal. Universitätsverlag Göttingen.

Dermawan, A., Dermawan, A., Petkova, E., Sinaga, A.C., Muhajir, M., Indriatmoko, Y., 2011. Preventing the Risks of Corruption in REDD+ in Indonesia. CIFOR, Bogor.

Edelman, M., 1977. The language of participation and the language of resistance. Hum. Commun. Res. 3 (2), 159-170.

Food and Agriculture Organization [FAO], 2010. Global Forest Resources Assessment 2010: Main Report. FAO, Rome.

Fay, C., Michon, G., 2005. Redressing forestry hegemony when a forestry regulatory framework is best replaced by an agrarian one. Forests Trees Livelihoods 15 (2), 193-209.

Galudra, G., Sirait, M., 2009. A discourse on Dutch colonial forest policy and science in Indonesia at the beginning of the 20th century. Int. For. Rev. 11 (4), 524-533.

Gellert, P.K., 2010a. Rival transnational networks, domestic politics and Indonesian timber. J. Contemp. Asia 40 (4), 539-567.

Gellert, P.K., 2010b. Extractive regimes: toward a better understanding of Indonesian development. Rural Sociol. 75 (1), 28-57.

Giessen, L., 2010. Regional Forest Governence-Potentials for Forestry and Political Drivers in Integrated Rural Development Policy. Goettingen University Press, pp. 313.

Giessen, L., Krott, M., 2009. Forestry joining integrated programs? A question of willingness, ability and opportunities. Allgemeine Forst-und Jagdzeitung 180 (5/6), 94-100

Giessen, L., 2011. Reviewing empirical explanations of policy change: options for its analysis and future fields of research. Allgemeine Forst-und Jagdzeitung 182 (11/12), 248-259.

Giessen, L., 2012. Temporary governance and persistent government - rural policy integration in pilot and mainstream funding programmes. In: Hogl, K., Kvarda, E., Nordbeck, R., Pregernig, M. (Eds.), Environmental Governance: The Challenge of Legitimacy and Effectiveness. Edward Elgar, pp. 155-177.

Giessen, L., 2013. Reviewing the main characteristics of the international forest regime complex and partial explanations for its fragmentation. Int. For. Rev. 15 (1), 60-70

Giessen, L., Hubo, C., Krott, M., Kaufer, R., 2013. Steuerungspotentiale von Zielen und Instrumenten des Politiksektors Forstwirtschaft und deren möglicher Beitrag zu einer nachhaltigen Entwicklung ländlicher Regionen. Zeitschrift für Umweltpolitik \& Umweltrecht 36 (3), 261-291

Giessen, L., Krott, M., Möllmann, T., 2014. Increasing representation of states by utilitarian as compared to environmental bureaucracies in international forest and forest - environmental policy negotiations. For. Policy Econ. 38, 97-104.

Gillespie, A., Michelson, M.R., 2011. Participant observation and the political scientist: possibilities, priorities, and practicalities. Polit. Sci. Polit. 44 (02), 261-265.

Hansen, M.C., Stehman, S.V., Potapov, P.V., Arunarwati, B., Stolle, F., Pittman, K., 2009. Quantifying changes in the rates of forest clearing in Indonesia from 1990 to 2005 using remotely sensed data sets. Environ. Res. Lett. 4 (3), 034001, http:// dx.doi.org/10.1088/1748-9326/4/3/034001

Hapsari, M., 2011. The Political Economy of Forest Governance in Post-Suharto Indonesia, Available at: http://www2.gsid.nagoya-u.ac.jp/blog/anda/files/2012/ 01/3maharani-hapsari 1.pdf (accessed 15.03.14).

Harris, N.L., Brown, S., Hagen, S.C., Saatchi, S.S., Petrova, S., Salas, W., Lotsch, A., 2012 Baseline map of carbon emissions from deforestation in tropical regions. Science 336 (6088), 1573-1576.

Halas, M., 2008. Relative and absolute gains problem in international relations. In: Paraskakis, I., Luneski, A. (Eds.), East European Doctoral Student Conference. South-East European Research Centre, pp. 375-385.
Hasanagas, N.D., 2014. Managing information in forest policy networks: distinguish ing the influential actors from the "postmen". For. Policy Econ., http://dx.doi.org/ 10.1016/j.forpol.2014.09.007

Haugaard, M., 2012. Rethinking the four dimensions of power: domination and empowerment. J. Polit. Power 5 (1), 33-54.

Hogl, K., Nordbeck, R., Kvarda, E., 2009. When international impulses hit home: the role of domestic policy subsystem configurations in explaining different types of sustainability strategies. For. Policy Econ. 11 (5), 357-364.

Howlett, M., Ramesh, M., 1995. Studying Public Policy: Policy Cycles and Policy Subsystems, 2nd ed. Oxford University Press, Toronto.

Hubo, C., Krott, M., 2013. Conflict camouflaging in public administration - a case study in nature conservation policy in Lower Saxony. For. Policy Econ. 33, 63-70.

Indonesia Corruption Watch [ICW], 2013. Forestry Corruption Cases Under KPK., Available at: http://www.antikorupsi.org/sites/antikorupsi.org/files/ doc/Umum/Lampiran\%20Data\%20ICW\%20\%20Catatan\%20Kejahatan \%20Kehutanan,\%20Kinerja\%20KPK,\%20Daftar\%20Kasus.pdf (accessed 4.04.14).

Irawan, S., Tacconi, L., Ring, I., 2014. Designing intergovernmental fiscal transfers for conservation: the case of REDD+ revenue distribution to local governments in Indonesia. Land Use Policy 36, 47-59.

Juerges, N., Newig, J., 2015. How interest groups adapt to the changing forest governance landscape in the EU: a case study from Germany. For. Policy Econ. 50, 228-235.

Kaoneka, A.R., 1999. Asia-Pacific forests, societies and environments. In: Palo M., Uusivuori, J. (Eds.), World Forests Society and Environment. Springer, Netherlands, pp. 178-185.

Kartodihardjo, H., Nagara, G., 2014. Kajian kerentanan korupsi dalam sistem perizinan di sektor sumberdaya alam (SDA): Studi kasus sektor kehutanan. In Penelitian sebagai pelaksanaan program litbang KPK. Presentation File, 15 January 2014, Jakarta.

Krause, R.M., 2011. Symbolic or substantive policy? Measuring the extent of loca commitment to climate protection. Environ. Plan. C: Govern. Policy 29 (1) 46-62.

Krott, M., 1990. Öffentliche Verwaltung im Umweltschutz: Ergebnisse einer behördenorientierten Policy-Analyse am Beispiel Waldschutz, vol. 5. W. Braumüller.

Krott, M., 2005. Forest Policy Analysis. Springer, Dordrecht.

Krott, M., Hasanagas, N.D., 2006. Measuring bridges between sectors: causative evaluation of cross-sectorality. For. Policy Econ. 8 (5), 555-563.

Krott, M., Bader, A., Schusser, C., Devkota, R., Maryudi, A., Giessen, L., Aurenhammer H., 2014. Actor-centred power: the driving force in decentralised community based forest governance. For. Policy Econ. 49, 34-42.

Krott, M., Glück, P., Whitby, M.C., Dawson, P.J., 1990. Forest land use policy: symbolic versus substantial planning. In: Land use for agriculture, forestry and rura development. Proceedings of the 20th symposium of the European Association of Agricultural Economists (EAAE), July 1989, Newcastle upon Tyne, England. Department of Agricultural Economics and Food Marketing, University of Newcastle upon Tyne, pp. 161-168.

Kumar, S., Kant, S., 2005. Bureaucracy and new management paradigms: modeling foresters' perceptions regarding community-based forest management in India. For. Policy Econ. 7 (4), 651-669.

Lenzen, M., Moran, D., Kanemoto, K., Foran, B., Lobefaro, L., Geschke, A., 2012. International trade drives biodiversity threats in developing nations. Nature 486 (7401), $109-112$.

Lukes, S., 2005. Power: A Radical View, 2nd ed. Macmillan, London.

Luttrell, C., Loft, L., Gebara, M.F., Kweka, D., Brockhaus, M., Angelsen, A., Sunderlin, W.D., 2013. Who should benefit from REDD+? Rationales and realities. Ecol. Soc 18 (4), 52, http://dx.doi.org/10.5751/ES-05834-180452

Marks, G., 1996. An actor-centred approach to multi-level governance. Reg. Fed. Stud. 6 (2), 20-38.

Maryudi, A., 2011. The Contesting Aspirations in the Forests: Actors, Interests and Power in Community Forestry in Java, Indonesia. Universitätsverlag Göttingen.

Maryudi, A., 2012. Restoring state control over forest resources through administrative procedures: evidence from a community forestry programme in Centra Java, Indonesia. ASEAS 5 (2), 229-242.

Mbatu, R.S., 2015. Domestic and international forest regime nexus in Cameroon: an assessment of the effectiveness of REDD+ policy design strategy in the context of the climate change regime. For. Policy Econ. 52, 46-56.

McCabe, A.C., 2013. A Three-Dimensional Analysis of Power and Engaged Scholarship. PhD thesis at the Queensland University of Technology, Queensland Australia.

McDermott, C.L., 2014. REDDuced: from sustainability to legality to units of carbon - the search for common interests in international forest governance. Environ. Sci. Policy 35, 12-19.

Mercer, J., 2005. Prospect theory and political science. Annu. Rev. Polit. Sci. 8, 1-21.

Moeliono, M., Gallemore, C., Santoso, L., Brockhaus, M., Di Gregorio, M., 2014. Information networks and power: confronting the "wicked problem" of REDD+ in Indonesia. Ecol. Soc. 19 (2), 9, http://dx.doi.org/10.5751/ES-06300-190209

Movuh, M.C.Y., 2012. The Colonial heritage and post-Colonial influence, entanglements and implications of the concept of community forestry by the example of Cameroon. For. Policy Econ. 15, 70-77.

Mwangi, E., Wardell, A., 2012. Multi-level governance of forest resources (editorial to the special feature). Int. J. Commons 6 (2) 79-103.

Nellemann, C., Interpol Environmental Crime Programme (Eds.), 2012. Green Carbon, Black Trade: Illegal Logging, Tax Fraud and Laundering in the Worlds Tropical Forests. A Rapid Response Assessment. United Nations Environment Programme, GRID-Arendal. 
Niskanen, W.A., 1974. Bureaucracy and Representative Government. Transaction Publishers, Chicago.

Ngadiono, 2004. 35 Tahun Pengelolaan Hutan Indonesia. Yayasan Adi Sanggoro, Bogor.

Nurrochmat, D.R., et al., 2014. Contesting national and international forest regimes: case of timber legality certification for community forests in Central Java Indonesia. For. Policy Econ., http://dx.doi.org/10.1016/j.forpol.2014.09.008

Ojha, H.R., Banjade, M.R., Sunam, R.K., Bhattarai, B., Jana, S., Goutam, K.R., Dhungana S., 2014. Can authority change through deliberative politics?: lessons from the four decades of participatory forest policy reform in Nepal. For. Policy Econ. 46, $1-9$.

Ojha, H.R., Cameron, J., Kumar, C., 2009. Deliberation or symbolic violence? The governance of community forestry in Nepal. For. Policy Econ. 11 (5), $365-374$

Olsen, J.P., 2006. Maybe it is time to rediscover bureaucracy. J. Public Adm. Res. Theory 16 (1), $1-24$.

Ongolo, S., 2015. On the banality of forest governance fragmentation: exploring "gecko politics" as a bureaucratic behaviour in limited statehood. For. Policy Econ., http://dx.doi.org/10.1016/j.forpol.2015.01.005

Palmer, C., 2001. The Extent and Causes of Illegal Logging: An Analysis of a Major Cause of Tropical Deforestation in Indonesia, Available at: http://discovery.ucl ac.uk/17588/1/17588.pdf (accessed 27.05.14).

Pauker, G.J., 1967. Toward a New Order in Indonesia. RAND Corporation, California, USA.

Pedersen, A.B., 2010. Why David sometimes defeats Goliath: the power of actors in disprivileged land-use policy networks. Land Use Policy 27 (2), 324-331.

Peters, B.G., 2001. Politics of Bureaucracy. Routledge, London.

Purnomo, A., 2012. Menjaga hutan kita: pro-kontra kebijakan moratorium hutan dan gambut. KPG, Jakarta.

Rahayu, Y., 2013. Peran data spasial kehutanan dalam era keterbukaaan dan transparansi informasi publik. In: Presentation File, 2 December 2013, Jakarta.

Rayner, J., Howlett, M., Wilson, J., Cashore, B., Hoberg, G., 2001. Privileging the subsector: critical sub-sectors and sectoral relationships in forest policy-making. For. Policy Econ. 2 (3), 319-332.

REDD-Monitor, 2012. Interview with Kuntoro Mangkusubroto, head of Indonesia's REDD+ Task Force: "We are starting a new program, a new paradigm, a new concept, a new way of seeing things", Available at: http://www.redd-monitor. org/2012/09/20/interview-with-kuntoro-mangkusubroto/ (accessed 29.05.14).

Resosudarmo, B.P., Ardiansyah, F., Napitupulu, L., 2013. The dynamics of climate change governance in Indonesia. In: Held, D., Roger, C., Nag, E.M. (Eds.), Climate Governance in the Developing World. Polity, Cambridge, pp. 73-90.

Rock, M.T., 2003. The Politics of Development Policy and Development Policy Reform in New Order Indonesia. Working Paper Number 632. William Davidson Institute, University of Michigan, USA.

Sadath, M.N., Krott, M., 2012. Identifying policy change - analytical program analysis: an example of two decades of forest policy in Bangladesh. For. Policy Econ. 25, 93-99.

Sahide, M.A.K., Giessen, L., 2015. The fragmented land use administration in Indonesia - analysing bureaucratic responsibilities influencing tropical rainforest transformation systems. Land Use Policy 43, 96-110.

Samadhi, N., 2013. Indonesia One Map: assuring better delivery of national development goals. In: Presented at the Geospatial World Forum 2013, 12-13 May 2013, Rotterdam, Available at: http://www.geospatialworldforum.org/2013/ presentation/Nirata\%20Samdhi.pdf (accessed 30.05.14).

Santosa, M.A., Khatarina, J., Suwana, A.S., 2013. The progress on governing REDD+ in Indonesia [Special edition]. Int. J. Rural Law Policy, Available at: http://epress. lib.uts.edu.au/journals/index.php/ijrlp/article/view/3356 (accessed 3.06.14).

Sayer, J.A., Collins, M., 2012. Forest governance in a changing world: reconciling local and global values. Round Table 101 (2), 137-146.

Schultze, U., Avital, M., 2011. Designing interviews to generate rich data for information systems research. Inf. Organ. 21 (1), 1-16.

Schusser, C., 2013. Who determines biodiversity? An analysis of actors' power and interests in community forestry in Namibia. For. Policy Econ. 36, 42-51.

Schusser, C., Krott, M., Logmani, J., 2013. The applicability of the German community forestry model to developing countries. Forstarchiv 84, 24-29.

Simangunsong, B.C.H., 2004. The Economic Performance of Indonesia's Forest Sector in the Period 1980-2002. Briefing Paper No. 4. Departemen Kehutanan Indonesia.

Singer, B., 2008. Putting the national back into forest-related policies: the international forests regime and national policies in Brazil and Indonesia. Int. For. Rev. $10(3), 523-537$.

Sloan, S., 2014. Indonesia's moratorium on new forest licenses: an update. Land Use Policy 38, 37-40

Sulistiawati, L.Y. Thesis (PhD) 2013. REDD+ Issues Influence in Indonesia's Regulatory Process Case Studies UNREDD Indonesia, REDD Plus Project Indonesia-Norway. University of Washington.
Tacconi, L., Moore, P.F., Kaimowitz, D., 2007. Fires in tropical forests - what is really the problem? Lessons from Indonesia. Mitig. adapt. Strateg. Global Change 12 (1), 55-66.

Uhlaner, C.J., 1989. Relational goods and participation: incorporating sociability into a theory of rational action. Public Choice 62 (3), 253-285.

Vis, B., Van Kersbergen, K., 2007. Why and how do political actors pursue risky reforms? J. Theor. Polit. 19 (2), 153-172.

Wardojo, W., Masripatin, N., 2002. Trends in Indonesian forest policy. Policy Trend Rep., 77-87.

Wibowo, A., Giessen, L., 2015. Actor positions on primary and secondary international forest-related issues relevant in Indonesia. J. Sustain. Dev. 8 (3), 10-27.

Wicke, B., Sikkema, R., Dornburg, V., Faaij, A., 2011. Exploring land use changes and the role of palm oil production in Indonesia and Malaysia. Land Use Policy 28 (1), 193-206

Yudhoyono, S.B., 2009. Intervention by H. E. Dr. Susilo Bambang Yudhoyono. In: President of the Republic of Indonesia, on climate change at the G-20 Leaders Summit 25 September 2009, Pittsburgh, Pennsylvania, USA Forest Climate Center, Indonesia, Available at: http://forestclimatecenter.org/files/2009-0925\%20Intervention\%20by\%20President\%20SBY\%20n\%20Climate\%20Change \%20at\%20the\%20G-20\%20Leaders\%20Summit.pdf (accessed 29.04.14).

\section{Policy documents cited}

Badan Informasi Geospasial [BIG], 2013. Dokumen Kesepakatan Rapat Koordinasi Nasional Informasi Geospasial Tahun 2013, Available at: http:// www.bakosurtanal.go.id/assets/download/DOKUMEN-KESEPAKATAN-RAPATKOORDINASI-NASIONALALL.pdf (accessed 29.04.14).

Dewan Nasional Perubahan Iklim [DNPI], McKinsey, 2009. Indonesia's Greenhouse Gas Abatement Cost Curve: Interim Report. DNPI, Jakarta.

Dewan Nasional Perubahan Iklim [DNPI], McKinsey, 2010. Indonesia’s Greenhouse Gas Abatement Cost Curve: Final Report. DNPI, Jakarta.

Dewan Nasional Perubahan Iklim [DNPI], 2013. Perubahan Iklim dan tantangan peradaban bangsa: 5 tahun DNPI 2008-2013. DNPI, Jakarta.

Government of Indonesia, 1999. Forest Law.

Komisi Pemberantasan Korupsi or Corruption Eradication Commission [KPK], 2013. Nota Kesepakatan Bersama: Percepatan pengukuhan kawasan hutan, Available at: http://acch.kpk.go.id/nota-kesepakatan-bersama-percepatan-pengukuhankawasan-hutan (accessed 28.05.14).

Ministry of Environment [MoE], 2009. Summary for Policy Makers: Indonesia Second National Communication under the United Nations Framework Convention on Climate Change (UNFCCC). Ministry of Environment, Jakarta.

Ministry of Environment [MoE], 2010. Indonesia Second National Communication under the United Nations Framework Convention on Climate Change (UNFCCC). Ministry of Environment, Jakarta.

Ministry of Forestry [MoF], 2008. IFCA 2007 Consolidation Report: Reducing Emissions from Deforestation and Forest Degradation in Indonesia. FORDA of the Ministry of Forestry, Jakarta.

Ministry of Forestry [MoF], 2013. Forestry Statistics of Indonesia 2012. Ministry of Forestry, Jakarta.

Ministry of Forestry [MoF], (n.d.). The system of public input mechanism for revision of the Indicative Map for Postponement of New Permit (PIPIB). Excel file. Jakarta: Ministry of Forestry.

President of Indonesia, 2010. Presidential Decree Number 19 on Task Force on REDD+ Institution Preparation.

Mulyani, M., Jepson, P., 2013. REDD+ and forest governance in Indonesia. A multistakeholder study of perceived challenges and opportunities. J. Environ. Dev. 22 (3), 261-283.

President of Indonesia, 2011. Presidential Instruction No 11 on the Postponement of Issuance of New Licences and Improving Governance of Primary Natural Forests and Peatland.

President of Indonesia, 2014. Presidential Regulation Number 190 on Presidential Staff Unit.

President of Indonesia, 2015a. Presidential Regulation Number 16 on the Ministry of Environment and Forestry.

President of Indonesia, 2015b. Presidential Instruction No 8 on the Postponement of Issuance of New Licences and Improving Governance of Primary Natural Forests and Peatland.

The Government of the Kingdom of Norway, The Government of the Republic of Indonesia, 2010. Letter of Intent between the Government of the Kingdom of Norway and the Government of the Republic of Indonesia on "Cooperation on reducing greenhouse gas emissions from deforestation and forest degradation", Available at: https://www.regjeringen.no/globalassets/upload/ smk/vedlegg/2010/indonesia_avtale.pdf (accessed 28.06.14). 
From voluntary private to mandatory state governance in Indonesian forest certification: Reclaiming authority by bureaucracies

Agung Wibowo*1 ${ }^{1}$ Muhammad Alif K. Sahide ${ }^{2}$ Lukas Giessen $^{3}$

*Corresponding author

${ }^{1}$ Chair Group of Forest and Nature Conservation Policy, Georg-August-Universität Göttingen, Büsgenweg 3, 37077 Göttingen/Germany. Email: agung.wibowo@ stud.uni-goettingen.de. Phone/Mobile/Fax: +49 55139 13391+49 0176 7975 3530/+490551393415. Permanent Affiliation: Faculty of Agriculture, University of Palangka Raya, Kampus UNPAR Tunjung Nyaho, J1. Yos Sudarso PO BOX 2/PLKUP, 73111 Palangka Raya/Indonesia

${ }^{2}$ Chair Group of Forest and Nature Conservation Policy, Georg-August-Universität Göttingen, Büsgenweg 3, 37077 Göttingen/Germany. Email: msahide@gwdg.de. Phone/Mobile/Fax: +49 55139 13391/ +49 1768296 0836/+490551393415. Permanent Affiliation: Laboratory on Forest Policy and Entrepreneurship, University of Hasanuddin, Makassar/Indonesia.

${ }^{3}$ Chair Group of Forest and Nature Conservation Policy, Georg-August-Universität Göttingen, Büsgenweg 3, 37077 Göttingen/Germany. Email: lgiesse @ gwdg.de. Phone/Fax: +49 55139 $33413 /+490551393415$

\section{Acknowledgements}

The authors gratefully acknowledge the German Academic Exchange Service (DAAD), the Eva Mayr-Stihl Foundation, the German Research Foundation (PAK 813) and the Indonesian Directorate General of Higher Education (DIKTI) for their funding supports. 


\section{Highlights}

- Voluntary forest certification failed in tackling deforestation and illegal logging

- Bureaucracies reclaim legitimacy from private forest certification governance

- $\quad$ State-based forest certification was chosen by business due to its mandatoriness

- Forest certification governance is going to simpler form

- We observe that forest certification dedicated to serve business interests more 
From voluntary private to mandatory state governance in Indonesian forest certification: Reclaiming authority by bureaucracies

\begin{abstract}
Forest certification has been introduced by non-state actors as a voluntary and market-based instrument addressing forest problems, which state policies failed to resolve. Lately, however, state-driven forest-related certification schemes can be observed, e.g. in Indonesia, through the EU FLEGT-VPA negotiation process. It is argued, specific state agencies in a struggle for power and authority develop mandatory certification schemes which are directly competing with private ones. Before this background, the aims of this study are: (i) describing the current trend from voluntary private to mandatory state certification schemes in Indonesia, (ii) mapping the main actors involved in certification politics, and (iii) explaining this trend with the interests of the main actors. The results confirm a trend from voluntary private to mandatory state-driven certification of forest management. The Ministry of Forestry, the Ministry of Trade, the Ministry of Industry, wood producer and processing associations, European Union, local funding organizations, environmental organizations, certification bodies and international buyers are detected as the main coalitions and actors in the certification politics. The stronger coalition develops a mandatorily-timber legality verification system as strategies to counter their voluntary private competitor schemes.
\end{abstract}

Keywords: Competition; Forest certification; Private governance; State governance; Bureaucratic politics

\title{
1. Introduction
}

As a response to the failed negotiations among governments on a global forest convention in 1992, forest certification has subsequently been introduced by non-governmental actor coalitions for promoting sustainable forest management (Boström, 2003; McDermott, 2014). There are two ideas underlying the emergence of the non-state-actor driven certification schemes, such as the Forest Steward Council (FSC). First, it was an effort by environmental non-governmental organizations to voluntarily certify well-managed forests in Europe and North America (Bartley, 2007). Second, such non-state, market-driven, and voluntary forest certification schemes also aimed to certify tropical and mega-diversity forests including problems such as vast deforestation, degradation and illegal logging (Gulbrandsen, 2004; Blackman et al., 2014).

Shortly after the FSC was launched in 1993, other voluntary, non-state certification schemes that were better known locally and that had more support from industry groups were founded during the 1990s to better accommodate local forestry practices. These included e.g. the Sustainable Forestry Initiative (SFI) and the American Tree Farm System (ATFS) in North America, the Programme for the Endorsement of Forest Certification (PEFC, ini tially the Pan-European Forest Certification) in Europe, the Sustainable Forest Management System in 
Canada, and Lembaga Ekolabel Indonesia (LEI) in Indonesia (Tosun, 2012; Maryudi 2006, 2009). All these forest certification initiatives have been largely driven by non-state, private actors and voluntary subscription and are consequently regarded as private institutions (Pattberg, 2007). They, yet, mirror an underlying competition between public and private actors over the authority to regulate forest management practices (Sikor, 2013).

However, the success of private certification schemes in tackling specific forestry problems like illegal logging, forest encroachment and deforestation, and in improving forest governance in developing countries thus far has been limited (Durst et al., 2006; Tacconi, 2007; Espach, 2006). As a consequence, a state-driven, inter-governmental cooperation between timber producer and consumer countries was initiated by the European Union (EU) in 2003, known as Forest Law Enforcement, Governance and Trade (FLEGT), aiming to certify the legality of harvested timber (Wiersum and Elands, 2013). Such state-based forest certification initiatives now counter-compete with private ones and are assumed having the potential to dominate and even replace private certification schemes (Nurrochmat et al., 2014; Malets, 2015).

Recent empirical findings support this latter perspective and suggest even a crucial role for state agencies in forest certification and related politics (Gale and Haward, 2011; Gulbrandsen, 2014). According to these literatures state agencies can obstruct (Gale and Haward, 2011) or support certification initiatives (Hysing, 2009; Bell and Hindmoor, 2012). More importantly, however, specific state bureaucracies, due to their formal mandate and ability to develop binding regulatory policy instruments, may even develop own certification schemes, as currently observed under the FLEGT process and regarding timber legality certification in Indonesia (Nurrochmat et al., 2014). In so doing, it is argued, state agencies develop mandatory certification schemes which are directly competing with private ones, and by this reclaim authority over forest certification through legitimized public actors. Before this background, the aims of this study are (i) describing the current trend from voluntary private to mandatory state certification schemes in Indonesia, (ii) mapping the main actors involved in certification politics, and (iii) explaining this trend with the interests of the main actors.

\section{Conceptual Framework}

\subsection{Voluntary private forest certification}

The FSC and PEFC forest certification systems have grown significantly and have become the largest in world, with a share of about $98 \%$ of all certified forest and chain of custody (CoC) certificates (FSC and PEFC, 2013). This amounts to 417 million hectares, or $10.3 \%$ of global forests area and a share of about $28 \%$ of the total round wood production (UNECE/FAO, 2013). This approach has successfully built a new mechanism in timber product trade by requiring all traded goods to meet a balance of ecological, social and economic requirements. By creating its own rules and simultaneously increasing public awareness of certified products, forest certification initiative governs the interaction between actors in forest product trade, and replaces the role of governments which failed to sign a global convention on forestry at the Earth Summit in 1992 (Bernstein and Cashore, 1999; van Kooten et al., 2005). 
This private forest certification has transformed into real governance ${ }^{1}$ (Pattberg, 2007). Depending on their viewpoints in specific studies, forest policy analysts refer to this phenomenon using various terms, like non-state global governance (Bernstein, 2011), nonstate market driven (NSMD) governance (Cashore, 2002; Cashore et al., 2007), non-state authority (Cashore et al., 2005), transnational (business) governance (Bartley, 2010), private forest governance (Pattberg, 2005), global forest governance (Gan et al., 2013), and global private meta-governance (Derkx and Glasbergen, 2014).

\subsection{Mandatory state certification}

At the 1998 G8 foreign ministers meeting, there was an agreement to cooperate with timberproducing countries in the development of their own measures to counter illegal logging and trading in illegally harvested timber (G8 Action Programme on Forests, 2002). Following this agreement, in 2003 the European Union (EU) declared the Forest Law Enforcement, Governance and Trade (FLEGT) action plan, which enabled producers from partner countries that had already signed FLEGT-voluntary partnership agreements (VPAs) to sell freely their legal products in EU territory (Brack, 2005, 2012). The agreement gave authority to partner countries to define "illegal timber" based on their own regulations, so that it acknowledged partner countries' sovereignty over their forests. To date, six countries, including Indonesia, have signed FLEGT-VPA, while nine others are in negotiations (EU FLEGT Facility, 2014). The FLEGT-VPA is seen as a more equitable type of cooperation, since it binds both producers and consumers to sell and to buy only legally harvested timber. In addition, the direct participation of consumer countries in the penalization of the sale of illegal wood-based products in their territory, as promised by the US through the Lacey Act (2008) and the by European Parliament through EU Timber Regulation (2010), is expected to diminish the space for illegal timber trade (Bartley, 2014). This is what cannot be addressed by voluntary forest certification initiatives such as FSC, PEFC, ISO 14000 or other more domestic initiatives (Solutions, 2003). Especially in Indonesia, the government has been forcing all forest logging companies and timber manufacturers to be certified under SVLK, a national timber legality assurance agreed upon in FLEGT-VPA.

\subsection{Bureaucratic politics and the power of actors}

We use bureaucratic politics theory in order to cover more broadly those actors that may be influencing policies related to forest certification at the national level. Bureaucracies are defined as "agencies that have been created by governments or other public actors with some degree or permanence and coherence and beyond formal direct control of single nation governments and that act in the international arena to pursue a policy" (Bauer e $\mathrm{t}$ al., 2012:28). Bureaucracies are different from organizations, which are institutional arrangements built upon normative frameworks, members, and bureaucracies as administrative core institutions. They are also different from institutions, which are merely sets of principles and norms (Bauer et al., 2012). Studies on bureaucracies' behavior (e.g. Krott, 1990; Peters, 2002) reveal that although bureaucracies have a formal mandate to serve

\footnotetext{
1 'Governance' is all about establishing, promoting and supporting a specific type of relationship between governmental and non-governmental actors in the governing process (Howlett et al., 2009:385).
} 
public interests, they will prioritize their own interests and compete with other bureaucracies for more resources, political domain and influence. To develop and direct specific policies, bureaucracies are equipped with power, which is defined as the ability to shape a programme according to own interests, even against resistance from other actors (Krott et al., 2014). According to Krott et al. (2014), power consists of three elements, namely (i) coercion, associated mostly with the ability to force an outcome, (ii) (dis-)incentives, the ability to offer (dis-)advantages to subordinate actors, and (iii) dominant information, selected information that is difficult or impossible to verify by another party. These power elements may be acquired through sanction mechanisms, transfer funds, and the expertise of bureaucracies.

Given the rise of mandatory state forest certification systems and the obstructions faced by voluntary private systems, state bureaucracies now have the following options: (i) increasing their power vis-à-vis other bureaucracies by developing own certification schemes, and (ii) reclaiming authority from private certification schemes to regulate forest management. Before this theoretical background this article will scrutinize these propositions using the following methods.

\section{Methods}

We employed document analysis, interviews, and observations to acquire solid data to meet our objectives. First, trends in the numbers of certified forest areas and certified companies under private (FSC and LEI) and state (Ministry of Forestry) certification schemes were drawn from the website of those bodies and were placed in charts to gain an overview of each initiative's progress and to make comparisons possible. Any information from professional journals or professional mailing lists, and position papers from international organizations and associations were also considered to be valuable sources.

Second, semi-structured interviews (Halperin and Heath, 2012) to identify the main actors within this issue and their positions were conducted in Jakarta and Bogor, Indonesia, during August 2013-February 2014, and were followed by online interviews until April 2014. The interviewees were staff from the Ministry of Forestry (MoF), the Ministry of Trade (MoT), and the Indonesian Woodworking Association (ISWA), the Forest Concessionaires Association (Asosiasi Pengusaha Hutan Indonesia or APHI), the Multistakeholder Forestry Programme (MFP), FSC Indonesia, certification auditors, and environmental nongovernmental organizations (ENGOs). We were also involved as observers in the respective meetings during that period to listen to each actor's ideas and to find out what expectations the actors had from others.

Third, actors' positions and their prospective coalitions were raised from theory of interest in environmental politics study. In analyzing actors' positions we assumed that every actor behaved rationally, meaning that actors tried to maximize their own benefit rather than to promote a general goal, like maintaining environmental sustainability and equality. To contest norm- and interest-driven is acceptable (see: Van Schaik and Schunz, 2012; Gulbrandsen, 2003) since each actor (which can be an individual, organization or state) has its own interest, adding to their effort to meet common desire. 


\section{Results}

\subsection{Voluntary private and mandatory state certifications' progress in} figures

Currently there are three forest certification schemes in Indonesia, namely the LEI and FSC, both of which are voluntary-private initiatives, and the PHPL (Pengelolaan Hutan Produksi Lestari or sustainable forest production management, a standard under SVLK) which is a mandatory state scheme. Forest certification assignment under the FSC was first conducted in 1998 and successfully certified three out of five assessed FMUs in Java, which was then followed by seven others within the next two years. However, all of these certificates were suspended and withdrawn in 2003 due to unsatisfactory management improvement and noncompliance with FSC standards (Muhtaman and Prasetyo, 2006). A new era of FSC standards-based certification was introduced in 2008, when six FMUs, with a total managed area of 707,709 ha, obtained sustainable certificates (FSC, 2008). This grew to 1,089,942 ha in 2009, then dropped to 638,455 ha in 2011, and peaked again at 2,002,710 ha in November 2014, representing the certified area of 29 FMUs (FSC, 2009, 2011, 2014).

Similarly, the first certification process using LEI standard was also conducted in 1998, and putting PT Diamond Raya Timber who managed 90,956 ha of natural production forest as the first cooperation obtained the certificate a year later (Muhtaman and Prasetyo, 2006). Since then, there has been no serial data available to the public until the LEI released FMU and manufacture LEI certified document (LEI, 2013), which mentioned that there were 1,873,428 ha of certified-forests, consisting of 411,690 ha of natural production forests (22\%) from two FMUs, 1,429,055 ha of plantation forests (76\%) managed by 15 FMUs, and 32,683 ha of community forests (2\%) from 22 community groups. Furthermore, the LEI (2014) informed that the certified natural forest area had dropped about 80\% within the period 2009-2014, and that the plantation forest area had increased $400 \%$ during that time.

Unlike the two previous voluntary schemes, PHPL is a mandatory state scheme enacted by the government in 2012, and effectively applied to all forest concessionaires and FMUs in 2013. The PHPL (SVLK)-certified forest area until May 2014 was 2,542,091 ha, representing an area managed by 40 FMUs (calculated from MoF, 2014). The certified forest area under the PHPL scheme was higher than those under FSC and LEI, even though the PHPL started in 2013 (Figure 1). It is likely that FSC- or LEI-certified FMUs are also certified under SVLK, since the processes to obtain such certificates are quite similar, and same certification body may carry out the late assessment. Consequently, the total certified forest area under the three schemes cannot represent the total sustainably managed forest area in Indonesia.

In respect of the chain of custody $(\mathrm{CoC})$ certification, there were six companies which held LEI certificates in 2009, and one of them did not reengage with the LEI in the second round (LEI, 2014). Conversely, the number of FSC CoC certificates doubled, from 87 in 2009 to 175 in 2012, and reached 193 by November 2014 (FSC, various years). A significant number of SLKs (sertifikat legalitas kayu or timber legality certificate; a form of certificate under the SVLK) were also issued by certification bodies, as the government started to force all exporters to provide V-legal documents for their wood products. By 2013, this number 
reached 726 companies (MoF, 2013) or almost four times the FSC holders, and grew continuously to 894 firms in 2014 (Table 1).

Figure 1. Size of certified forest area under FSC, LEI and SVLK schemes in the period 2006-2014

Table 1. Number of companies holding FSC, LEI and SVLK certificates

\subsection{Cost of sustainable forest certification and legality verification}

The cost of forest certification and timber legality verification are vary, depends on the size of forest area, investment capital, and production capacity of the company. This cost applied at first assessment to gain the certificate and at yearly surveillance within certificate's validity period. Cost component charged by certification body to the company including fee for auditors, data and information collection, field assessment, reporting fee, documentation, and security assistance for auditors if needed. For SVLK scheme the Minister of (Environment and) Forestry released the Ministry Regulation P.13/2013, which amended by P.96/2014, on the standard cost for sustainable forest management assessment and timber legality verification. It is mentioned that the total cost for legality assessment for small and medium scale-wood processing industry could reach 6.6 million IDR, and up to 28.8 and 170 million IDR for bigger industry and large forest management units, respectively. In the meantime, the cost for forest sustainability assessment is around 222-280 million IDR and up to 132 million IDR for its yearly surveillance. All these costs are excluding travelling cost for auditors from Jakarta to the field. From private certification side, there is no official data on the cost of assessment and surveillance processes available for public. Pratiwi (2015) reported that the costs paid by the companies for gaining FSC, LEI and PHPL-SVLK certificates are at least 31,60 , and 75 million IDR, respectively, depends on the scale of company.

\subsection{Mapping main actors and their interests}

Actors involved in forest certification in Indonesia are found along the productionconsumption chain, starting with the actors initiating certification schemes and ending with buyers in consumer countries. The following are three groups of influential actors and their roles in shaping recent construction based on their tendencies and interests.

\subsubsection{State certification supporting group}

\section{The Ministry of Forestry}

The Ministry of Forestry $(\mathrm{MoF})$ was the main state agency responsible for establishing the national timber legality assurance system called SVLK. The SVLK installation process began in 2003, when the MoF organized some civil social organizations, i.e., Telapak, Environmental Investigation Agency, Indonesian Ecolabel Institute, and the Nature Conservancy to hold a series cross sectoral dialog in developing SVLK (MFP, 2014). SVLK, which enacted through the Minister of Forestry Regulation No P.38/2009, and up to December 2014 was already five times amended (MoF, 2011; 2012; 2013; 2014a; MoEF, 2014a), has become the core of Indonesia-EU FLEGT-VPA negotiation. The MoF tried to apply the SVLK comprehensively to all forest industry and timber manufacturers 
immediately, in order to maintain the credibility of the SVLK and the MoF. However, due to external pressure, the MoF (which was transformed into the Ministry of Environment and Forestry or MoEF in October 2014) extended the deadline for obtaining the certificates and simplified some provisions in the SVLK so that small and medium-sized enterprises could join it (see MoF, 2014b; MoEF, 2014b).

\section{The Ministry of Trade}

The Ministry of Trade (MoT) has the mission of increasing the added value and volume of exported goods by setting up regulations to support progressive export activities. Regarding wood legality, the MoT issued a regulation on the export of forestry industrial products, whereby one group of export timber products had to have V-Legal documents in 2013, and another group had to have these in 2014 (MoT, 2012). However, since the small-scale enterprise group was not ready by the deadline, the MoT delayed the inclusion of V-Legal documents in export requirements until 2015 (MoT, 2013a), and postponed it again until 2016 (MoT, 2014a). The latest delay was taken to meet the MoT's ambition in increasing the export value of wood products by $300 \%$ within the next 5 years (Kompas, 2014). Aside from setting up regulations for ease of export, the MoT was also actively involved in SVLK negotiation with the EU and in promoting SVLK so that Indonesian furniture demand grew up by $15-20 \%$ in 2014 (MoT, 2014b).

\section{The Ministry of Industry}

The Ministry of Industry (MoI) supports the SVLK as the way to expand overseas markets for wooden industrial products. However, the small-scale industry's unreadiness for certification and the high cost associated with it forced the MoI to ask the MoF and MoT for a delay in SVLK implementation of one year and for simplification of the SVLK verifier, mainly for wooden furniture and handicraft products (AMKRI, 2014). Previously, in March 2013, the MoI had also accommodated SMEs' scruple on SVLK and vowed to discuss a relief for them with the MoF (AgroIndonesia, 2013).

\section{Indonesian Forest Concessionaires Association (APHI) and the Indonesian Pulp and Paper Association (APKI)}

The Indonesian Forest Concessionaires Association (APHI) and the Indonesian Pulp and Paper Association (APKI), as representatives of big players in the Indonesian wood industry, actually support the SVLK, in order to improve their product image in the global market (Agrofarm, 2013). Nevertheless, since end buyers ask for FSC-certified products, local industries have to opt exclusively for FSC-certified timber in their production line. Consequently, SVLK-certified intermediary goods cannot be sold locally, let alone in the global market (The Jakarta Post, 2014b) and the producers have to bear a double cost to tackle the problem (Hutan Indonesia, 2013). Since the SVLK is designed to comply with an agreement with the EU (Pohnan and Stone, 2013), the policy of making the SVLK obligatory for all logging companies and wood-processing industries is considered detrimental to local businesses and industries not oriented towards the European market. Both associations have already asked the government to open more local markets for SVLK-certified products and to promote the SVLK more broadly. 
Indonesian Sawmill and Woodworking Association (ISWA), Association of Indonesian Furniture and Crafts Producers (Asmindo) and small tree growers

Small wood industries and small tree growers support the SVLK, associating it with better market access in Europe and other countries (The Jakarta Post, 2014a; Agroobserver, 2015). However, they warn that the requirements for small industries should be simpler than those for big ones, since small tree growers work in private land parcels, and they do their own planting and harvesting (AgroIndonesia, 2014). They also may change the use of the land or sell it in a traditional way, without permits from anybody else. Hence, they don't have to "formalise" their business by means of legal permits, taxation, environmental assessment and other administrative documents, which are costly (Obidzinski et al., 2014).

\section{European Union (EU)}

EU efforts to halt illegal timber circulation inside and outside the region are evident in the two main regulations under the FLEGT Action Plan, namely the FLEGT-VPA and the EU Timber Regulation (EUTR). The EUTR can be seen as an economic tool to strengthen the position of European timber against its competitors, since any wood products to be exported to Europe have to pass a due diligence investigation by operators (van Heeswijk and Turnhout, 2013). In contrast, the FLEGT-VPA, which includes a timber legality assurance system (TLAS) from the producer country, ignores the due diligence process for FLEGT-licensed products. In the case of the SVLK, both Indonesia and EU parties signed and ratified the VPA in 2014 and acknowledged SVLK as Indonesian TLAS. However, the EU support for the SVLK cannot be seen simply as a passport of sorts for Indonesia's wood products entering EU territory, since it could be suspended once a SVLK-licensed product is discredited (Hawin et al., 2010).

\section{The Multistakeholder Forestry Programme (MFP) and Kehati Foundation}

The MFP is a UK-funded program that assists the MoF in developing and promoting the SVLK, and in helping FMUs and small enterprises to obtain SVLK-based certificates through its coaching program (Raharjo, 2013). Together with the MoF, the MFP was engaged in SVLK negotiations with the EU. The MFP also strongly encourages the government of Indonesia to implement SVLK and rejects its delay, which the industry sector has requested often. The Kehati foundation, on the other hand, is a national funding agency that supports activities related to biodiversity conservation. Both the MFP and Kehati reckon that SVLK is in line and could be the way to succeed REDD+ program (Dharmawan et al., 2012).

\subsubsection{Private certification supporting group Environmental Non-Governmental Organizations (ENGOs)}

Most leading ENGOs support private certification initiatives to achieve better forest governance. These include: the Borneo Initiative, the Tropical Forest Foundation and the WWF-Global Forest and Trade Network, which work on the LEI and FSC schemes, and Greenpeace and the Nature Conservancy, which work on the FSC (Greenpeace, 2014). These ENGOs promote schemes they support and decline others for reasons of lack of accountability, poor sustainability standards and double costs consequence, among others. A network of ten ENGOs, called the Anti Forest-Mafia Coalition has criticized the SVLK, judging it to be flawed and a new form of "greenwashing" illegal timber (Anti Forest-Mafia Coalition, 2014). However, their members also help small enterprises to obtain SVLK 
certificates (Antara, 2015). Some of them publish SVLK's weaknesses repeatedly, even though they do not show their partiality to private forest certification schemes.

\subsubsection{Hybrid group Certification Bodies}

Currently there are 18,2 and 4 certification bodies working on the SVLK, the FSC and the LEI, respectively (MoF, 2013; various sources) where some of them work with more than one scheme. Certification bodies have the right to issue certificates of sustainable forest management practice or chain of custody and the right to withdraw such a certificate during an annual inspection if the holders no longer comply with the standards of a given certification scheme. Due to a disproportional ratio between the certification body and number of areas/companies to be certified, the certification cost is increasing and is becoming unaffordable for small industries (Obidzinski et al., 2014). The principle of transparency in the audit process makes it possible for one certification body to know what other bodies do, what auditor works for which body, and the certification fees applied to particular audit process. Furthermore, once a certification body has conducted an audit, it has to announce the plan or the results on determined website so that it is open to input from independent observers, NGOs, and other stakeholders. The transparency principle allows the work of the certification body to be criticized; hence, the certificates already issued may be withdrawn for many reasons. Frequently revocations of certificates will affect not only the certification body, but also the certification scheme they use.

\section{International buyers}

After FLEGT-VPA signation, timber certified for sustainability and timber certified for legality compete for consumer demand for eco-friendly products. International buyers, as the end users of such products, will choose between state-based certified products and privatebased certified woods. Accordingly, it is important to provide potential buyers with appropriate information on own products' superiority (Cashore, 2002). Potts et al. (2010) point out that major retailers in North America have decided to choose forest products derived from sustainable sources, whereas EU countries require importers, manufacturers, and retailers to have chain of custody $(\mathrm{CoC})$ certification that clarifies the origin of their timber. Cai and Aguilar (2013) compiled 19 studies on consumer's willingness-to-pay for certified wood products, and found that $1-39 \%$ of consumers were willing to pay premium prices for these products, no matter what kind of label it had. This means that the number of consumers willing to pay a higher price for certified products was less than that of those unwilling to pay. Consumers do not care whether products are certified or not, let alone whether the certification initiatives are private or governmental.

\section{Discussion}

\subsection{Fragmented certification schemes and their coalition alliances}

Based on policy-making authority, Cashore (2002) divides environmental governance into three categories, namely, "non-state market driven governance", characterized by the lack of government involvement in the policy-making process; "shared private/public governance", in which policy-making is shared with the government; and "traditional governance", where policy-making authority belongs fully with the government. Gulbrandsen (2004) uses the term 
"private governance" to refer to NSMD governance, and "public governance" (meaning state governance) for traditional governance. Gulbrandsen (2004) adds hybrid private-public governance to denote industry-dominated involvement in mixed private and public governance. Following categorization by Cashore (2002) and Gulbrandsen (2004) we found that there are now four clusters of forest certification governance present in Indonesia, namely environmental-private governance, hybrid private-public governance, producer-private governance, and state governance, with the FSC, the LEI, the PEFC and the SVLK representing each scheme, respectively (Table 2).

Table 2. Cluster of forest certification governance in Indonesia-

Except for the LEI, the other three schemes have their supporting actors who promote the schemes' excellence. Due to the lack of capital, human resource and interest affinity, and therefore we argue that the hybrid private-public government will disappear, and the FMUs and wood industries will make alliances with the government to support traditional forest governance. The PEFC could join the SVLK, since the PEFC originally devoted for forest owners and forest managers. Consequently, there will be only two certification schemes competing for authority in the future, namely, the pro-environment and pro-business schemes. The first scheme is represented by the FSC and would be supported by ENGOs, academics and the pro-environmental community, and the LEI, since LEI already signed a joint certification protocol with the FSC. With this collaboration, the FSC has a local partner to introduce its more local-value adapted scheme, and the LEI could maintain its presence in the forest certification field. Conversely, the pro-business scheme consists of SVLK and PEFC will mutually reinforce and possible to make joint recognition for effective certification process, and wider market access. This scheme is supported by the government, landowners, and FMUs. Due to the wider stakeholder involvement and its mandatory nature, this scheme seems to flourish continuously, as indicated by its progress in the year of early implementation.

Through this process, the forest certification regime becomes less complex, since national political processes replace and reduce the international element of international forest regimes, and standard of these schemes may less different (McDermott et al., 2008). Industrial groups, as the users of the certification scheme, have to engage with the SVLK to maintain their business continuity and to enter the market, and only add the FSC to improve their reputation. However, the solidity of this pattern will become more stable under the following conditions. First, if the government of Indonesia promotes the SVLK and its acceptance in other consumer countries, hence industries will need no other certification scheme when exporting their products to such countries. Second, if the government preserves the SVLK as a reputable certification scheme by publishing data having to do with the ways in which the SVLK contributes to the deforestation rate reduction and to the enhancements of society and ecology. Third, if there are fewer or no objections from other stakeholders about the performance of industries that are SVLK-certified, indicating that these companies do business in legal and sustainable ways. 


\subsection{Mandatoriness and cost of SVLK as strategy for reclaiming authority over other actors}

By making the SVLK mandatory for all FMUs and timber manufacturers, the MoF may gain at least three benefits. First, it could increase its presence in downstream industry circles by financing the first SVLK-certification process for small enterprises (Neraca, 2014). Through this assistance, the MoF would gain power over small enterprises, which in the past have belonged in the domain of the MoI. Second, compelling the enterprises to choose SVLK only or either SVLK and private schemes. The high cost of legality verification and forest certification is the main factor obstructing companies to engage with those processes (Tacconi, 2007; Obidzinski, 2014), although it does not always correspond to its benefits. Pratiwi (2015) shows that only around $24 \%$ of industry, forest companies and their related associations state that the cost of SVLK-certification is worth its benefits, while only $26 \%$ of them acknowledge that they always receive premium prices from their certified products. The gap between the cost and the benefits resulting from certification process forces business actors to be realistic in choosing appropriate certification scheme. This selection strongly depends on their market target and value of the exported products (see Fikru, 2014). If combination of mandatory and voluntary certification costs were higher than the profit, business tended to choose only the SVLK for their products. Third, as consequence of the previous point, the SVLK may be better known and legitimate in domestic and overseas markets. With only around $10 \%$ share of Indonesian timber export value goes to Europe (MoF, 2014c), the obligation to put V-legal sign (sign for SVLK-certified products) in all exported timber products will make SVLK better known in other major destination countries like China, Japan, and South Korea.

\subsection{Granting privileges to large-scale industries over smallholders?}

It is widely known that small scale wood industries and tree growers are characterized by limited administration records, production-by-demand orientation, simple management practices, and have less capacity to follow market dynamics (Nurrochmat, 2004). Obidzinski et al. (2014) point out the major challenges to small and medium enterprises (SMEs) in obtaining SVLK-based certificates, namely: business legality status; limited supply of legal timber; small profit margins spread over a long value chain; high certification costs; and small volume and unpredictable harvest times. Under these circumstances it is hard for them to obtain wood legality certificates (S-LK; SVLK-based certificate) even if the trees grown in home yards and their transfers to processing industries are truly legal. The lack of verification bodies and the limited financial support by government are other obstacles for the engagement of small industries in SVLK schemes (Obidzinski et al., 2014). Hence, the policy of implementing SVLK certification in all wood industries is thought to be a simple way to increase export value to European markets by large industries, at the expense of SMEs. On the other hand, the export ban policy for non-certified industry will cut USD 900 million in annual income for SMEs, which amounts to $30 \%$ of the total wood export value to nonEuropean markets, excluding pulp and paper (Agroindonesia, 2014). To avoid this loss, the MoT has postponed the implementation of such a policy twice already, and vows to implement it in January 2016. 
It seems that the MoT places foreign market access and trade performance as the top priority, followed by the survival of large scale industries, wood legality, the subsistence of SMEs, and facility of sales for small tree growers. This policy might limit the circulation of illegal wood, facilitate the supervision of the industry and increase the trust in the SVLK; but it suppresses small and very locally-oriented industries, and creates a disincentive for small tree growers. Small tree growers face legal consequences and may even be found guilty of criminal charges when they harvest and transfer wood from their garden to small wood industries. A more local and adaptive policy that is able to distinguish illegal timber and -incomplete documented timber -like a conformity declaration already being considered- is needed for this kind of business (Kemitraan, 2014), in order to avoid negative social consequences.

\section{Conclusions}

The Ministry of (Environment and) Forestry was under political pressure from other bureaucracies, and was asked to improve its performance in generating income from forest areas. The Ministry then used its authority to govern forest product circulation and trade in domestic and global markets through the forest certification initiative. This program has at least four goals: first, to show the public its efforts in reducing illegal logging and the deforestation rate; second, to restore the forestry sector as the main contributor to state income, as it was in 1990s; third, to preserve its existence by obliging all FMUs and wood industries to be certified by such a scheme and to become the agency in charge of the Indonesia-EU agreement on FLEGT; and lastly, to increase the state sovereignty over forests, by being the institution to decide on the legality of timber. The involvement of the MoF in the forest certification arrangement indicates that private governance is not the final and stable form of this regime, as is argued by some scholars (e.g. Hackett, 2013; Overdevest and Zeitlin, 2014). In addition, the MoF uses its authority to reclaim authority over private actors. The MoF is likely to succeed, due to the ease of implementation and simple standards of the scheme, which also account for the relatively inexpensive cost of certification assessment fee, in comparison to its competitors. Furthermore, the mandatory nature of the SVLK means it has fixed a downstream market, i.e., FMUs and wood industries, whilst upstream it can profit from an educated market that has already been created by private governance. In this case, the state governance seems to be the free rider.

A remaining question needs to answer by both governances is whether their presence is able to reduce forest loss and to sustain forest management. Since $18 \%$ of deforested area in Indonesia is open land and the rest is designated for development purposes (Kissinger et al., 2012), we argue that the certification regime will be unable to reduce forest conversions. Most of the forest conversions were planned and allowed by the government, and that is why these, together with other "deforested areas", were not included in the calculation of the deforestation rate (Bellot et al., 2014). In addition, the sustainability criteria of certification regimes do not reflect the fact that small tree growers do clear-cutting when they need cash for unforeseen expenses, like a marriage or educational costs, and that they do not replant their gardens. Hence, legality verification and sustainability certification are disconnected from forest (land) management performed by small tree growers or forest companies. Based on these points, we argue that the certification regime and legality verification are merely 
instruments to govern timber trade (indicated as transnational business governance by Lesniewska and McDermott, 2014) at the expense of small and traditional tree growers, rather than an effort to secure remaining tropical forests. 


\section{References}

\section{Literature}

Bartley, T. (2007). How foundations shape social movements: The construction of an organizational field and the rise of forest certification. Social Problems, 54(3), 229-255.

Bartley, T. (2010). Transnational private regulation in practice: The limits of forest and labor standards certification in Indonesia. Business and Politics, 12(3), Article 7. DOI: 10.2202/1469-3569.1321.

Bartley, T. (2014). Transnational governance and the re-centered state: Sustainability or legality?. Regulation \& Governance, 8(1), 93-109.

Bauer, S., Andresen, S., \& Biermann, F. (2012). International bureaucracies. In: Biermann, F., \& Pattberg, P. H. (Eds.). Global environmental governance reconsidered. MIT Press. p.27-44.

Bell, S., \& Hindmoor, A. (2012). Governance without government? The case of the Forest Stewardship Council. Public Administration, 90(1), 144-159.

Bellot, F.F, Bertram, M. , Navratil, P., Siegert, F. \& Dotzauer, H. (2014). The high-resolution global map of 21st-century forest cover change from the University of Maryland ('Hansen Map') is hugely overestimating deforestation in Indonesia. Available at: http://forclime.org/images/documents/FORCLIME_Overestimation\%20of\%20Deforestat ion.pdf [Accessed 14 November 2014].

Bernstein, S., \& Cashore, B. (1999). World trends and Canadian forest policy: trade, international institutions, consumers and transnational environmentalism. Forestry Chronicle, 75(1), 34-38.

Bernstein, S. (2011). Legitimacy in intergovernmental and non-state global governance. Review of International Political Economy, 18(1), 17-51.

Boström, M. (2003). How state-dependent is a non-state-driven rule-making project? The case of forest certification in Sweden. Journal of environmental policy \& planning, 5(2), 165-180.

Blackman, A., Raimondi, A., \& Cubbage, F. (2014). Does forest certification in developing countries have environmental benefits? Insights from Mexican Corrective Action Requests. Insights from Mexican Corrective Action Requests (March 31, 2014). Resources for the Future Discussion Paper, (14-06).

Brack, D. (2005). Controlling illegal logging and the trade in illegally harvested timber: the EU's Forest Law Enforcement, Governance and Trade Initiative. Review of European community \& international environmental law, 14(1), 28-38.

Brack, D. (2012). Excluding illegal timber and improving forest governance: The European Union's Forest Law Enforcement, Governance and Trade initiative. In: High-Value Natural Resources and Peacebuilding, ed: P. Lujala and S. A. Rustad. London: Earthscan. p. 211-220.

Cai, Z., \& Aguilar, F. X. (2013). Meta-analysis of consumer's willingness-to-pay premiums for certified wood products. Journal of Forest Economics, 19(1), 15-31.

Cashore, B. (2002). Legitimacy and the privatization of environmental governance: How non- state market-driven (NSMD) governance systems gain rule-making authority. Governance, 15(4), 503-529.

Cashore, B., Auld, G., \& Newsom, D. (2005). Governing through markets: Forest certification and the emergence of non-state authority. Journal of Environmental Planning and Management, 48(4), 619-624.

Cashore, B., Egan, E., Auld, G., \& Newsom, D. (2007). Revising theories of nonstate marketdriven (NSMD) governance: lessons from the Finnish forest certification experience. Global Environmental Politics, 7(1), 1-44.

Colchester, M., Sirait, M., \& Wijardjo, B. (2003). Obstacles and Possibilities: the Application 
of FSC Principles 2 \& 3 in Indonesia. WAHLI and AMAN.

Derkx, B., \& Glasbergen, P. (2014). Elaborating global private meta-governance: An inventory in the realm of voluntary sustainability standards. Global Environmental Change, 27, 41-50.

Dharmawan, A. H., Nugroho, B., Kartodihardjo, H., Kolopaking, L. M., \& Boer, R. (2012). SVLK, Jalan Menuju REDD+. Forest Governance and Multistakeholder Forestry Programme, Ministry of Forestry Indonesia-UK Department for International Development.

Durst, P. B., McKenzie, P. J., Brown, C. L., \& Appanah, S. (2006). Challenges facing certification and eco-labelling of forest products in developing countries. International Forestry Review, 8(2), 193-200. DOI: 10.1505/ifor.8.2.193.

Espach, R. (2006). When is sustainable forestry sustainable? The forest stewardship council in Argentina and Brazil. Global Environmental Politics,6(2), 55-84.

Fikru, M. G. (2014). International certification in developing countries: The role of internal and external institutional pressure. Journal of environmental management, 144, 286-296.

Fishman, A., \& Obidzinski, K. (2014). European Union Timber Regulation: Is it legal?. Review of European, Comparative \& International Environmental Law,23(2), 258-274.

Gale, F., \& Haward, M. (2011). Global commodity governance: state responses to sustainable forest and fisheries certification. Palgrave Macmillan.

Gan, J., Cashore, B., \& Stone, M. W. (2013). Impacts of the Lacey Act Amendment and the Voluntary Partnership Agreements on illegal logging: implications for global forest governance. Journal of Natural Resources Policy Research, 5(4), 209-226.

Giessen, L., \& Krott, M. (2009). Forestry joining integrated programmes? A question of willingness, ability and opportunities. Allgemeine Forst-und Jagdzeitung, 180(5/6), 94100.

Gulbrandsen, L. (2003). The evolving forest regime and domestic actors: strategic or normative adaptation?. Environmental Politics, 12(2), 95-114.

Gulbrandsen, L. H. (2004). Overlapping public and private governance: Can forest certification fill the gaps in the global forest regime? Global Environmental Politics, 4(2), 75-99.

Gulbrandsen, L. H. (2014). Dynamic governance interactions: Evolutionary effects of state responses to non-state certification programs. Regulation \& Governance, 8, 74-92.

Hackett, R. (2013). From government to governance? Forest certification and crisis displacement in Ontario, Canada. Journal of Rural Studies, 30, 120-129.

Halperin, S., \& Heath, O. (2012). Political research: methods and practical skills. Oxford University Press.

Hawin, M., Nurhayati, I. \& Antoni, V. (2010). Analisis hukum teks Voluntary Partnership Agreement antara Indonesia dan Eropa. Jakarta: Forest Governance and Multistakeholder Forestry Programme.

Hinrichs, A. (2005). Lembaga Ekolabel Indonesia-Introduction and implementation of forest certification in Indonesia. In: D. Burger, J. Hess, B. Lang (Eds.). Forest Certification: An innovative instrument in the service of sustainable development?, Eschborn, Germany: Deutsche Gesellschaft für Technische Zusammenarbeit (GTZ). P. 135-153.

Howlett, M., Rayner, J. and Tollefson, C. (2009). From government to governance in forest planning? Lessons from the case of the British Columbia Great Bear Rainforest initiative. Forest Policy and Economics, 11, 389-391. DOI: 10.1016/j.forpol.2009.01.003.

Hutan Indonesia. (2013). Mengejar Tenggat Sertifikasi PHPL Mandatory. Hutan Indonesia, III, 26-27.

Hysing, E. (2011). Transnational environmental governance: the emergence and effects of the certification of forests and fisheries by Lars H. Gulbrandsen (Cheltenham, UK: Edward Elgar). Environment and Planning. C, Government and Policy, 29(3), 567-568. 
Kissinger, G., Herold, M., \& De Sy, V. (2012). Drivers of deforestation and forest degradation: a synthesis report for REDD+ policymakers. Vancouver: Lexeme Consulting.

Krott, M. (1990). Öffentliche Verwaltung im Umweltschutz. Ergebnisse einer behördenorientierten Policy-Analyse am Beispiel Waldschutz. Wien: W. Braumüller Verlag.

Krott, M., Bader, A., Schusser, C., Devkota, R., Maryudi, A., Giessen, L., \& Aurenhammer, H. (2014). Actor-centred power: The driving force in decentralised community based forest governance. Forest Policy and Economics, 49, 34-42.

Lesniewska, F., \& McDermott, C. L. (2014). FLEGT VPAs: Laying a pathway to sustainability via legality lessons from Ghana and Indonesia. Forest Policy and Economics. DOI: 10.1016/j.forpol.2014.01.005.

Malets, O. (2015). when transnational standards hit the ground: Domestic regulations, compliance assessment and forest certification in Russia. Journal of Environmental Policy \& Planning, 17(3), 332-359.

Maryudi, A. (2006). Sertifikasi Hutan: Instrumen Baru Dalam Kebijakan Kehutanan. Rimba Kalimantan, 11(1), 27-35.

Maryudi, A. (2009). Forest certification for community-based forest management in Indonesia: Does LEI provide a credible option?. Hayama-mati (Kanagawa-ken): Institute for Global Environmental Strategies, Forest Conservation, Livelihoods, and Rights Project.

McDermott, C. L., Noah, E., \& Cashore, B. (2008). Differences that 'matter'? A framework for comparing environmental certification standards and government policies. Journal of Environmental Policy and Planning, 10(1), 47-70.

McDermott, C. L. (2014). REDDuced: From sustainability to legality to units of carbon-The search for common interests in international forest governance. Environmental Science and Policy, 35, 12-19.

Muhtaman, D. R., \& Prasetyo, F. A. (2006). Forest certification in Indonesia. In: Cashore, B. et al. (eds). Confronting sustainability: Forest certification in developing and transitioning countries. Yale University Faculty of Environmental Studies Publication Series, 33-68.

Nurrochmat, D. R. (2004). Social forestry to alleviate poverty: concepts and expe-riences in Indonesia. In: Poverty Alleviation: Concepts and Experiences: Focused on Indonesian Cases . Cuvillier. Verlag Göttingen. p. 39-44

Nurrochmat, D. R., Dharmawan, A. H., Obidzinski, K., Dermawan, A., \& Erbaugh, J. T. (2014). Contesting national and international forest regimes: Case of timber legality certification for community forests in Central Java, Indonesia. Forest Policy and Economics, DOI:10.1016/j.forpol.2014.09.008

Obidzinski, K., Dermawan, A., Andrianto, A., Komarudin, H., \& Hernawan, D. (2014). The timber legality verification system and the voluntary partnership agreement (VPA) in Indonesia: Challenges for the small-scale forestry sector. Forest Policy and Economics. DOI: $10.1016 /$ j.forpol.2014.06.009.

Overdevest, C., \& Zeitlin, J. (2014). Assembling an experimentalist regime: Transnational governance interactions in the forest sector. Regulation \& governance, 8, 22-48.

Pattberg, P. H. (2005). The Forest Stewardship Council: Risk and potential of private forest governance. The Journal of Environment \& Development, 14(3), 356-374.

Pattberg, P. H. (2007). Private institutions and global governance: the new politics of environmental sustainability. Edward Elgar Pub.

Pattberg, P. H. (Ed.). (2012). Public-private partnerships for sustainable development: Emergence, influence and legitimacy. Edward Elgar Pub.

Peters, G. (2002). Politics of Bureaucracy. Routledge. 
Pohnan, E., \& Stone, M. (2013). Can legality verification combat illegal logging in Indonesia? Strategic insights for policy makers and advocates. Issues and Options Brief. IUFRO Task Force on Forest Governance, 16 November 2013.

Potts, J., van Der Meer, J., \& Daitchman, J. (2010). The state of sustainability initiatives review 2010: Sustainability and transparency.

Pratiwi, S. (2015). Comparing forest certification and legality verification system and explaining stakeholder preferences in Indonesia. Master Thesis. University of Goettingen.

Raharjo, D. (2013). Laporan Akhir Multistakeholder Forestry Programme (MFP2). Ministry of Forestry of Republic of Indonesia, KEHATI, UKAID. Jakarta. pp. 109.

Suntana, A. S., Asycarya, D., Iskandarsyah, Y. \& Iswari, P. (eds.). (2000). Sustainable Production Forest Management (SPFM) Certification System. Bogor: The Indonesian Ecolabeling Institute.

Sikor, T. (Ed.). (2013). Public and private in natural resource governance: a false dichotomy?. Routledge.

Solutions, S. G. T. (2003). Establishing the foundation for sustainable forest management in Africa: Legal origin of timber as a step towards sustainable forest management. SGS, Geneva. Available at: http://siteresources.worldbank.org/EXTFORESTS/Resources/ 985784-1217874560960/AFRLegalOrigin.pdf [Accessed 10 January 2015].

Suntana, A. S., Asycarya, D., Iskandarsyah, Y. \& Iswari, P. (eds.). (2000). Sustainable Production Forest Management (SPFM) Certification System. Bogor: The Indonesian Ecolabeling Institute.

Tacconi, L. (2007). Verification and certification of forest products and illegal logging in Indonesia. In: Tacconi, L. (Editor). Illegal logging: law enforcement, livelihoods and the timber trade. London: Earthscan. p. 251-274.

Tosun, J. (2012). Forest certification in Europe: Exploring the determinants of cross-country variation. Marmara Journal of European Studies, 20(1), 177-197.

UNECE (United Nations. Economic Commission for Europe)/FAO (Food and Agriculture Organization (2013). Forest Products Annual Market Review, 2012-2013. New York and Geneva, United Nations, Geneva Timber and Forest Study Paper, 33.

van Heeswijk, L., \& Turnhout, E. (2013). The discursive structure of FLEGT (Forest Law Enforcement, Governance and Trade): The negotiation and interpretation of legality in the EU and Indonesia. Forest Policy and Economics, 32, 6-13.

van Kooten, G. C., Nelson, H. W., \& Vertinsky, I. (2005). Certification of sustainable forest management practices: a global perspective on why countries certify. Forest Policy and Economics, 7(6), 857-867.

van Schaik, L., \& Schunz, S. (2012). Explaining EU Activism and Impact in Global Climate Politics: Is the Union a Norm-or Interest-Driven Actor?. JCMS: Journal of Common Market Studies, 50(1), 169-186.

Wiersum, K. F., \& Elands, B. H. (2013). Opinions on legality principles considered in the FLEGT/VPA policy in Ghana and Indonesia. Forest Policy and Economics, 32, 14-22.

\section{Empirical materials and regulations cited}

Agrofarm (2013). Tidak ada insentif, SVLK bebani APHI. Available at: http://www.agrofarm.co.id/m/kehutanan/121/tidak-ada-insentif-svlk-bebani-aphi/\#. U_Ros_1_tps [Accessed 14 January 2015].

Agroindonesia (2013). Komitmen Indonesia tetap terjaga. Available at: http://agroindonesia.co.id/2013/03/19/komitmen-indonesia-tetap-terjaga [Accessed 14 January 2015].

Agroobserver (2015). ISWA: Pemerintah diharap jangan hambat industri barecore dari 
sengon. Available at: http://agroobserver.com/iswa-pemerintah-diharap-jangan-hambatindustri-barecore-dari-sengon/ [Accessed 14 January 2015].

AMKRI (Asosiasi Mebel dan Kerajinan Indonesia) (2014). Menteri Perindustrian Saleh Husin setujui penundaan pemberlakuan sistem verifikasi legalitas kayu (SVLK). Available at: http://www.amkri.org/berita/menteri-perindustrian-saleh-husin-setujuipenundaan-pemberlakuan-sistem-verifikasi-legalitas-kayu-(svlk)--337.php [Accessed 14 January 2015].

Antara (2015). WWF-Asmindo bantu industri kecil kehutanan peroleh SVLK. Available at: http://www.antarajatim.com/lihat3/berita/149907/wwf-asmindo-bantu-industri-kecilkehutanan-peroleh-svlk [Accessed 20 February 2015].

Anti Forest-Mafia Coalition (2014). SVLK flawed: An independent evaluation of Indonesia's timber legality certification system. Available at: http://eyesontheforest.or.id/attach/Anti\%20Forest\%20Mafia\%20Coalition\%20\%2818Mar 14\% 29\%20SVLK\%20Flawed\%20FINAL.pdf [Accessed 14 January 2015].

EU FLEGT Facility (2014). VPA countries. Available at: http://www.euflegt.efi.int/vpacountries [Accessed 14 June 2014].

European Commission (2013). Questions and answers on the EU and Indonesia agreement on illegal timber. European Commission-MEMO/13/828. Available at: http://europa.eu/rapid/press-release_MEMO-13-828_en.html [Accessed 14 June 2014].

FSC (Forest Stewardship Council) (2008, 2009, 2011, 2014). Global FSC certificates: type and distribution. Available at: https://ic.fsc.org/facts-figures.19.html [Accessed 14 Mach 2015].

FSC (Forest Stewardship Council) (2010). FSC Directive on FSC Forest Management Evaluations. Available at: https://www.scsglobalservices.com/files/standards/FSC-DIR20-007_EN.pdf [Accessed 14 June 2014].

FSC (Forest Stewardship Council) \& PEFC (Programme for the Endorsement of Forest Certification) (2013). Joint statement by the Forest Stewardship Council (FSC) and the Programme for the Endorsement of Forest Certification (PEFC) recommending ISO member to vote against the new work item proposal Chain of Custody of Forest Based Products-Requirements. Available at: http://www.pefc.org/images/documents/external/ Joint_StatementFSC_PEFC_July_8_2013.pdf [Accessed 12 June 2014].

FSC (Forest Stewardship Council) (2014). FSC harmonised certification bodies' Forest Stewardship Standard for the Republic of Indonesia. Available at: http://www.scsglobalservices.com/files/standards/fsc-std-idn-01-01-2013 indonesianatural plantations and slimf.pdf [Accessed 14 December 2014].

G8 Action Programme on Forests (2002). G8 action programme on forests-Final report . www.illegal-logging.info/item_single.php?it_id=38\&it=document [Accessed 14 January2015].

Greenpeace (2014a). Weaker certification schemes. Other forest industry driven certification schemes fail to meet basic performance indicators. Available at: http://www.greenpeace.org/ international/en/campaigns/forests/solutions/alternatives-toforest-destruc/Weaker-Certification-Schemes/ [Accessed 14 December 2014].

Kemitraan (2014). Terobosan baru dalam SVLK: conformity declaration untuk hutan rakyat dan industri kecil menengah. Available at: http://www.kemitraan.or.id/sites/default/ files/Press\%20Release\%20Self\%20Declare\%20SVLK\%20Kemitraan-160514final.pdf [Accessed 14 March 2015].

Kompas (2014).Ini aturan baru legalitas kayu. Available at: http://bisniskeuangan.kompas.com/read/2014/12/30/090900326/Ini.Aturan.Baru.Legalitas .Kayu [Accessed 14 January 2015].

LEI (Lembaga Ekolabel Indonesia) (2013). FMU and Manufacture LEI Certified. Updated: July

2013.

Available

at: 
http://www.lei.or.id/files/FMU\%20\&\%20Manufacture\%20certified\%20LEI_July\%20201 3.pd f [Accessed 14 November 2014].

LEI (Lembaga Ekolabel Indonesia) (2014). Laporan Kegiatan Lembaga Ekolabel Indonesia 2009-2014. LEI.

MFP (Multistakeholder Forestry Programme). (2014). SVLK: Meningkatkan perdagangan produk kayu legal dari Indonesia. Infobrief, December 2014. Available at:

http://www.mfp.or.id/attachments/article/89/SVLK\%20in\%20brief_IND_FA.pdf [Accessed 14 January 2015].

MKI (Majalah Kehutanan Indonesia) (2011). Negosiasi panjang FLEGT-VPA tuntas. Edition X/2011, p. 5-7.

MoF (Ministry of Forestry) (2009). Ministry Regulation No P. 38/Menhut-II/2009 on Performance appraisal standard and guidelines of sustainable production forest management and timber legality verification.

MoF (Ministry of Forestry) (2011). Ministry Regulation No P. 68/Menhut-II/2011 on First amendment of Ministry Regulation No P. 38/Menhut-II/2009 on performance appraisal standard and guidelines of sustainable production forest management and timber legality verification.

MoF (Ministry of Forestry) (2012). Ministry Regulation No P. 45/Menhut-II/2012 on Second amendment of Ministry Regulation No P. 38/Menhut-II/2009 on performance appraisal standard and guidelines of sustainable production forest management and timber legality verification.

MoF (Ministry of Forestry) (2013). Ministry Regulation No P. 42/Menhut-II/2013 on Third amendment of Ministry Regulation No P. 38/Menhut-II/2009 on performance appraisal standard and guidelines of sustainable production forest management and timber legality verification.

MoF (Ministry of Forestry) (2014a). Ministry Regulation No P. 43/Menhut-II/2014 on performance appraisal of sustainable production forest management and timber legality verification.

MoF (Ministry of Forestry) (2014b). Circular letter from Director General of Forest Enterprises No: SE.8/VI-BPPHH/2014 on concerning obligations fulfillment related to timber legality verification system (SVLK).

MoF (Ministry of Forestry) (2014c). SVLK development, Commitment to sustainable forests for sustainable trade.

MoEF (Ministry of Environmental and Forestry) (2014a). Ministry Regulation No P. 95/Menhut-II/2014 on Ministry Regulation No P. 43/Menhut-II/2014 on performance appraisal of sustainable production forest management and timber legality verification.

MoEF (Ministry of Environmental and Forestry) (2014b). Circular letter from Director General of Forest Enterprises No: SE.14/VI-BPPHH/2014 on concerning obligations fulfillment related to timber legality verification system (SVLK).

MoT (Ministry of Trade) (2012). Ministry Regulation No. 64/M-DAG/PER/10/2012 on Export provision on forest industrial products.

MoT (Ministry of Trade) (2013a). Ministry Regulation No. 81/M-DAG/PER/12/2013 on Amendment on Ministry Regulation No. 64/M-DAG/PER/10/2012 on export provision on forest industrial products.

MoT (Ministry of Forestry) (2013b). Keunggulan SVLK sebagai penguat produk nasional. Seminar Kehutanan Indonesia, Jakarta 16 Desember 2013. p.42. (presentation file).

MoT (Ministry of Forestry) (2014). Data PHPL. Available at: http://www.dephut.go.id/index.php/common/phpl [Accessed 14 March 2015].

MoT (Ministry of Trade) (2014). Diplomasi perdagangan Wamendag di London: SVLK berdampak positif bagi ekspor kayu Indonesia. Available at: http://www.kemendag.go.id/id/news/2014/06/04/diplomasi-perdagangan-wamendag-di- 
london-svlk-berdampak-positif-bagi-ekspor-kayu-indonesia [Accessed 14 December 2014].

Neraca (2014). Usaha kecil akan dibantu sertifikasi legalitas kayu. Available at: http://www.neraca.co.id/industri/43685/Usaha-Kecil-Akan-Dibantu-Sertifikasi-LegalitasKayu [Accessed 14 January 2015].

PEFC (2013). PEFC Continues Expansion in the Tropics. Available at: http://pefc.org/newsa-media/general-sfm-news/1087-pefc-continues-expansion-in-the-tropics [Accessed 14 March 2015].

Suara Pembaruan (2013). Kayu RI tak perlu sertifikat FSC. Available at: http://www.suarapembaruan.com/ekonomidanbisnis/kayu-ri-tak-perlu-sertifikat-fsc/ 40301 [Accessed 14 March 2015].

The Jakarta Post. (2014a). Indonesia aims long-term timber export growth in EU. Available at: http://www.thejakartapost.com/news/2014/03/01/indonesia-aims-long-term-timberexport-growth-eu.html [Accessed 1 January 2015].

The Jakarta Post. (2014b). APKI wants more access to local market. Available at: http://m.thejakartapost.com/news/2014/07/19/apki-wants-more-access-local-market.html [Accessed 14 January 2015].

UNEP (United Nations Environment Programme) (2013). Green economy and trade-trends, challenges and opportunities. Available at: http://www.unep.org/greeneconomy/ Portals/88/GETReport/pdf/FullReport.pdf [Accessed 14 March 2015]. 
Table 1. Number of companies holding FSC, LEI and SVLK certificates

\begin{tabular}{llll}
\hline \multirow{2}{*}{ Year } & \multicolumn{3}{l}{ Number of certified companies under each scheme } \\
\cline { 2 - 4 } & FSC & LEI & SVLK \\
\hline 2009 & 87 & 6 & - \\
2010 & 136 & 6 & - \\
2011 & 161 & 6 & - \\
2012 & 175 & 6 & - \\
2013 & 188 & 6 & 726 \\
2014 & 193 & 5 & 894 \\
\hline
\end{tabular}

Source: FSC (various years), LEI (2013, 2014), MoF (2014).

Table 2. Cluster of forest certification governance in Indonesia

\begin{tabular}{|c|c|c|c|c|}
\hline Key features & $\begin{array}{l}\text { Environmental- } \\
\text { private governance } \\
\text { (FSC) }\end{array}$ & $\begin{array}{l}\text { Hybrid private- } \\
\text { public } \\
\text { governance } \\
\text { (LEI) }\end{array}$ & $\begin{array}{l}\text { Producer-private } \\
\text { governance } \\
(\mathrm{PEFC})\end{array}$ & $\begin{array}{l}\text { State governance } \\
\text { (SVLK) }\end{array}$ \\
\hline Rule maker & Environmentalists & Academics & Land owners & Government \\
\hline $\begin{array}{l}\text { State } \\
\text { involvement }\end{array}$ & No & Partially & Limited & Full \\
\hline $\begin{array}{l}\text { Supporting } \\
\text { actor }\end{array}$ & ENGOs & No & Industry & Government \\
\hline Territorial focus & International & $\begin{array}{l}\text { National } \\
\quad \text { (Indonesia) }\end{array}$ & International & $\begin{array}{l}\text { National } \\
\text { (Indonesia) }\end{array}$ \\
\hline Auditor & Third party & Third party & Third party & Third party \\
\hline $\begin{array}{l}\text { Public } \\
\text { examination }\end{array}$ & Yes & Yes & Yes & Yes \\
\hline $\begin{array}{l}\text { Certificate } \\
\text { acceptability }\end{array}$ & International & National & International & EU and National \\
\hline Brand image & Strong & Weak & Quite strong & Weak \\
\hline $\begin{array}{l}\text { Industry } \\
\text { participation }\end{array}$ & Voluntary & Voluntary & Voluntary & Mandatory \\
\hline Actor involved & $\begin{array}{l}\text { Business } \\
\text { business }\end{array}$ & $\begin{array}{l}\text { Business } \\
\text { business }\end{array}$ & $\begin{array}{l}\text { Business } \\
\text { business }\end{array}$ & $\begin{array}{l}\text { Government to } \\
\text { government and } \\
\text { business to } \\
\text { business }\end{array}$ \\
\hline $\begin{array}{l}\text { Law } \\
\text { enforcement }\end{array}$ & No & No & No & Yes \\
\hline
\end{tabular}




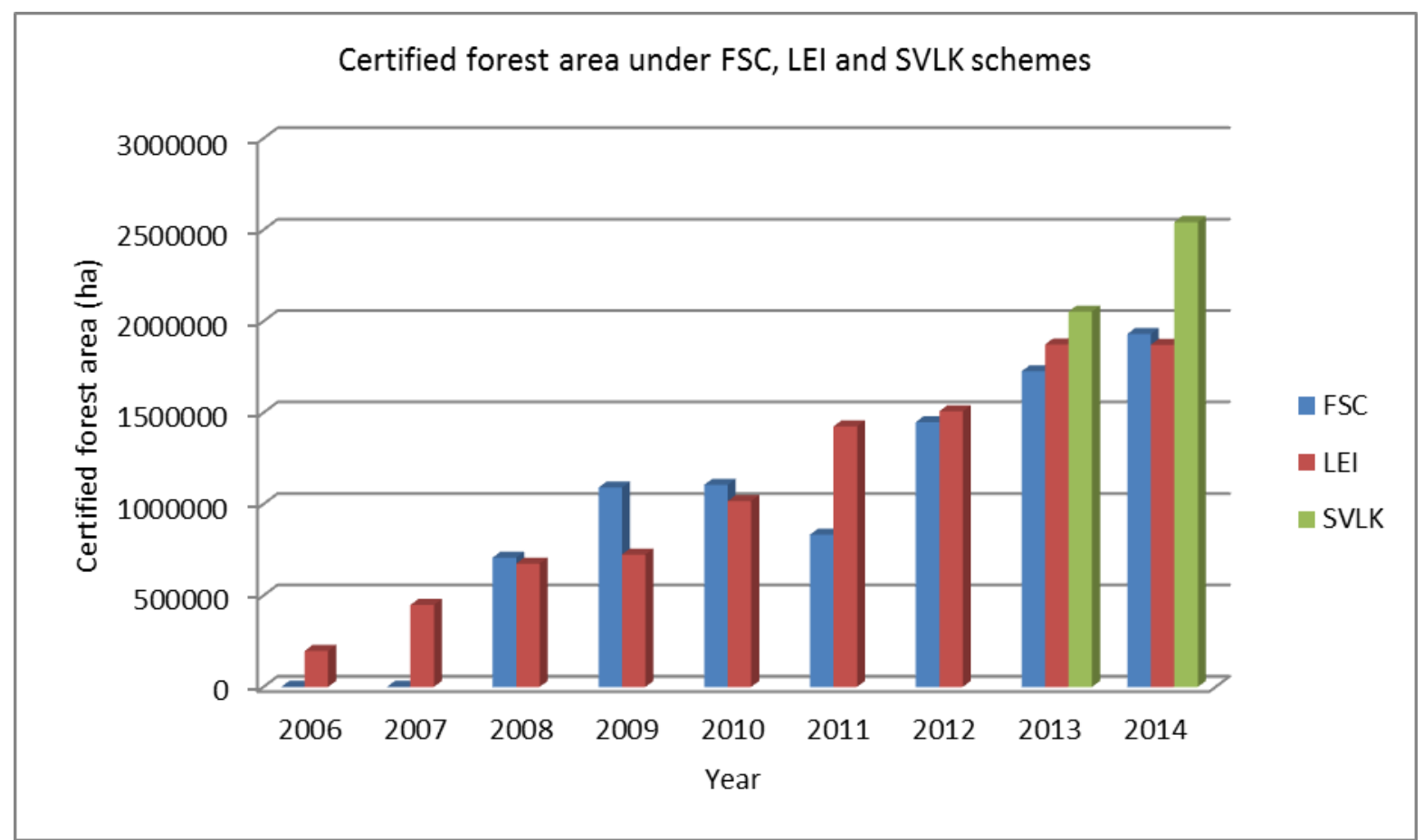

Source: FSC (various years), LEI (various years) and MoF (various years).

Figure 1. Size of certified forest area under FSC, LEI and SVLK schemes in the period 20062014 


\title{
Third-Party Certification of Forest Management In Indonesia: Analysing Stakeholders' Recognition and Preferences
}

\author{
Santi Pratiwi $^{1,3^{*}}$, Agung Wibowo ${ }^{2,3}$, Lukas Giessen ${ }^{3}$ \\ ${ }^{1}$ South Sumatera Nature Conservation Agency, Ministry of Environment and Forestry, Jl. Kol. H. Burlian KM 6 No. 79 \\ Puntikayu, Palembang, Indonesia 30153 \\ ${ }^{2}$ Department of Forestry, Faculty of Agriculture, University of Palangka Raya, Kampus UNPAR Tunjung Nyaho, Jl. Yos \\ Sudarso PO Box 2/PLKUP, Palangka Raya, Indonesia 73111 \\ ${ }^{3}$ Chair of Forest and Nature Conservation Policy, Georg-August-Universität Goettingen, Buesgenweg 3, Goettingen, Germany
} 37077

Received May 20, 2015/Accepted July 28, 2015

\begin{abstract}
The existence of third-party forest and timber certification schemes in Indonesia has created benefits and challenges, mainly for forest industries. In the end, the interests and objectives of those industries will determine whether they decide to get certified and if so, what certification schemes they will use. This study analyses the stakeholder recognition of the competing forest legality and sustainability certification systems and describes the preferences for particular schemes based on stakeholder interests. Online questionnaires were distributed to relevant stakeholders, namely logging companies, wood processing industries, wood processing associations, auditors, academics, environmental organisations and government officials. The results indicate that there are different scheme preferences based on the stakeholder's interests. Sistem Verifikasi Legalitas Kayu (SVLK) is the most frequently preferred scheme due to the simplicity of its requirements and the low cost of its certifying process, while the Forest Stewardship Council (FSC) is valued for its reputation and very high standards. Furthermore, Lembaga Ekolabel Indonesia (LEI) was least preferred because of its complexity and because it was unpopular with foreign end buyers, and the Programme for the Endorsement of Forest Certification (PEFC) was identified as being a complex scheme that was expensive and subject to high standards, and also appeared to have the least demand. Each scheme should be improved based on stakeholders' expectations, that their popularity with end buyers of timber products should be improved, and that this should be done in a way that allows logging and wood processing industries to choose freely the scheme that is most advantageous to them
\end{abstract}

Keywords: forest certification schemes, timber legality system, preferences, forest and timber industries

*Correspondence author, email: santi.pratiwi04@gmail.com,phone: +62-85998057975

\section{Introduction}

Forest certification is an information tool and a marketbased instrument (Upton \& Bass 1995; Rametsteiner \& Simula 2003) that ensures that the forest and its management conform to a particular standard (Nussbaum \& Simula 2005). Forest certification was initially advanced by environmental groups as a response to the consequences of deforestation and forest degradation in the early 90s (Rametsteiner \& Simula 2003; Leslie 2004). A massive campaign to produce and use only certified timber products has turned forest certification into a new form of governance in international trade and business (Haufler 2003; van Kooten et al. 2005).

Currently, there are 3 entities providing voluntary-private forest certification schemes in Indonesia, namely the forest stewardship council (FSC), the programme for the endorsement of forest certification (PEFC, implemented by the indonesian forest certification cooperation or IFCC), and the Indonesian ecolabelling institute or lembaga ekolabel Indonesia (LEI). In addition, there is one mandatory state forest and timber legality certificate system, namely the timber legality verification system or sistem verifikasi legalitas kayu (SVLK, including the sustainable production forest management scheme or pengelolaan hutan produksi lestari/PHPL). By 2014, there were 2,002,710 ha of forest that had been certified under the FSC scheme, adding 193 chain of custody (CoC) certificates for wood-based industries across the country (FSC 2014). In the same year 17 PEFC-based CoC certificates (PEFC 2014) were also issued, as were 39 sustainability certificates for $1,970,175$ ha of forest and $6 \mathrm{CoC}$ certificates using the LEI scheme (LEI 2014), in addition to 826 legality certificates for wood processing industries (SILK 2014).

The existence of many third-party certification schemes has created benefits and barriers for the stakeholders 
involved (Thornber et al. 1999; Hansen et al. 2005), especially logging companies and the wood processing industry. In theory, the existence of many options would make it easy for stakeholders to choose a scheme that best suits their interests and needs (Gulbrandsen 2003). Tuppura et al. (2015) have described a number of motivations forest companies may have for becoming certified, namely authorities' orders, clients' wishes, improving their image, distinguishing themselves from their competitors, opening new markets, increasing internal control, and risk management and long-term profitability. The selection of favourable certification schemes by the companies is not always easy, due to some of the constrains they face, e.g., complexity of certification requirements, lack of verification/certification bodies, limited amount of financial subsidies (Obidzinski et al. 2014), unclear land use regimes (Sahide et al. 2015), the cost of certification, schemes' legitimacy (Nurrochmat et al. 2014), market orientation and the schemes' acceptability (Wibowo et al. 2014).

The dilemma faced by industries has become more complicated since the government decided to make SVLK mandatory for all logging companies and wood processing industries (MoE Regulation Number 38/2009). It is within this context that we assess stakeholders' recognition of and preferences for third party forest certification schemes in Indonesia. Our main research questions are:

(i) what schemes do businesses prefer?

(ii) what criteria do businesses consider, in making their selection?

\section{Methods}

Businesses' motivations for becoming certified were gleaned from the FSC (2008), Faggi et al. (2014), Lozano (2013) and Tuppura et al. (2015). From this close-ended questionnaires that included additional aspects that may apply in Indonesia. In addition, an open space for personal opinion were provided.

The key respondents were those who had been involved with the legality verification system in Indonesia and were therefore familiar with it. The respondents were categorised into main respondents, which consisted of those from logging companies (LC), from the wood processing industry (WPI) and from the wood processing association (WPA), and supporting respondents, which consisted of auditors, environmental organisation representatives, academics, and government officials. These respondent groups were chosen due to their strong interests (Krott 2005) and influences (Steffek 2009) in forest governance.

The questionnaires were divided into 3 types, one each for (i) LC and WPI, (ii) WPA, and (iii) supporting respondents. The questionnaires consisted of two sections. The first, General Information, included the name of the respondent, the type of respondent (type of stakeholder), workplace, and contact information. The second, Stakeholder Preferences, consisted of the respondents' experiences and perceptions of each of the four schemes' characteristics, e.g., their market acceptance, the complexity of their requirements, and the ease with which certificates from each could be obtained. The questionnaires were sent to the respondents along with introductory and personal information in the body of an email. The online questionnaires were distributed in January and February 2015 through personal email, mailing lists, association channels, and social media. Out of 508 personal emails sent 108 replies $(21 \%)$, comprising stakeholders from logging companies ( 23 persons), from the wood processing industry (23 persons), from the wood processing association (7 persons), auditors (22 persons), environmental organisation representatives (18 persons), academics (11), and government officials/Ministry of Environment and Forestry employees (MoEF) (4 persons). Eight respondents replied and did not fill the questionnaires due to lack of updated knowledge and company privacy. The data obtained from the questionnaires were tabulated into an Excel file database and the answers for each of the closed questions were transformed into bar and pie charts.

\section{Results and Discussion}

Ease of procurement The key stakeholders believed that the SVLK and LEI certificates were easier certificates to obtain than the FSC and PEFC certificates (Figure 1). About $91 \%$ and $69 \%$ of the logging company respondents expressed that SVLK and LEI were the easiest certificates to obtain, while only $31 \%$ and $22 \%$ of them said the same for PEFC and FSC, respectively. The ease of access to the information on how to apply for SVLK certification is a key reason for this. This finding contradicts the research by Obidzinski et al. (2014), which indicated that achieving SVLK compliance was not easy due to the many challenges involved. According to the respondents, LEI is easier because of its assessment system.

A similar trend is seen in the WPI group, where $69 \%$ and $57 \%$ said that SVLK and LEI are easier to obtain. The rest of the group, $48 \%$ and $31 \%$, said that the FSC and PEFC are easier to obtain. The trend is quite different for WPA respondents, where SVLK (71\%), FSC (58\%), LEI (57\%) and PEFC (29\%) were considered to be easy to obtain. The WPA and WPI respondents believe that SVLK is the easiest certificate to obtain, because the SVLK is a mandatory arrangement established by the government, has clear indicators, criteria and verifiers and is easier to apply. The SVLK is also cheaper because the cost of certification for a smallholder company can be paid by the Ministry of Environment and Forestry (MoEF Regulation Number 95/2014). In addition, SVLK standards are simpler.

Complexity of requirements Almost all respondents in the four groups agreed that FSC standards are more complex than those of the PEFC, LEI and SVLK (Figure 2). In the auditors group, all respondents (100\%) thought that the FSC is the most complex standard, followed by the LEI $(86 \%)$, PEFC (82\%) and SVLK (55\%). A similar trend was shown for the environmental organisations, where the respondents thought that the FSC $(89 \%)$ and PEFC $(72 \%)$ were more complex than the LEI (61\%) and SVLK (39\%). The same trend is observed in the academics group, where the respondents answered that the FSC (73\%) and PEFC (73\%) are more complex than the LEI (54\%) and SVLK (45\%). The respondents from the government official group thought that 
the LEI (75\%) and the SVLK (75\%) are more complex than the FSC $(50 \%)$ and PEFC (50\%).

The FSC is the most difficult certificate to get, and the scheme involved is even impossible for some industries. One of the respondents said that FSC uses political judgments in establishing forest certification rules so as to protect their market from the new certification schemes, so that the environmentally friendly wood products had to be associated with and certified by the FSC. This opinion is also supported by the results showing that the FSC has the highest standards of all schemes, which implies difficulties in procuring the corresponding certificate (Taylor 2005, Nukpezah et al. 2014). FSC standards are complex and adhere strictly to the principles, criteria and indicators of FSC International. However, the certification body can make FSC standards become easier or more difficult to comply with, since it has authority to interpret the ways in which those standards must be met. Hence, one certification body can have easier assessments and another can have more complicated ones (Gulbrandsen 2004). The challenges for the FSC in becoming a friendlier scheme for industries are the limited amount of information smallholders have about it, the difficulty in the

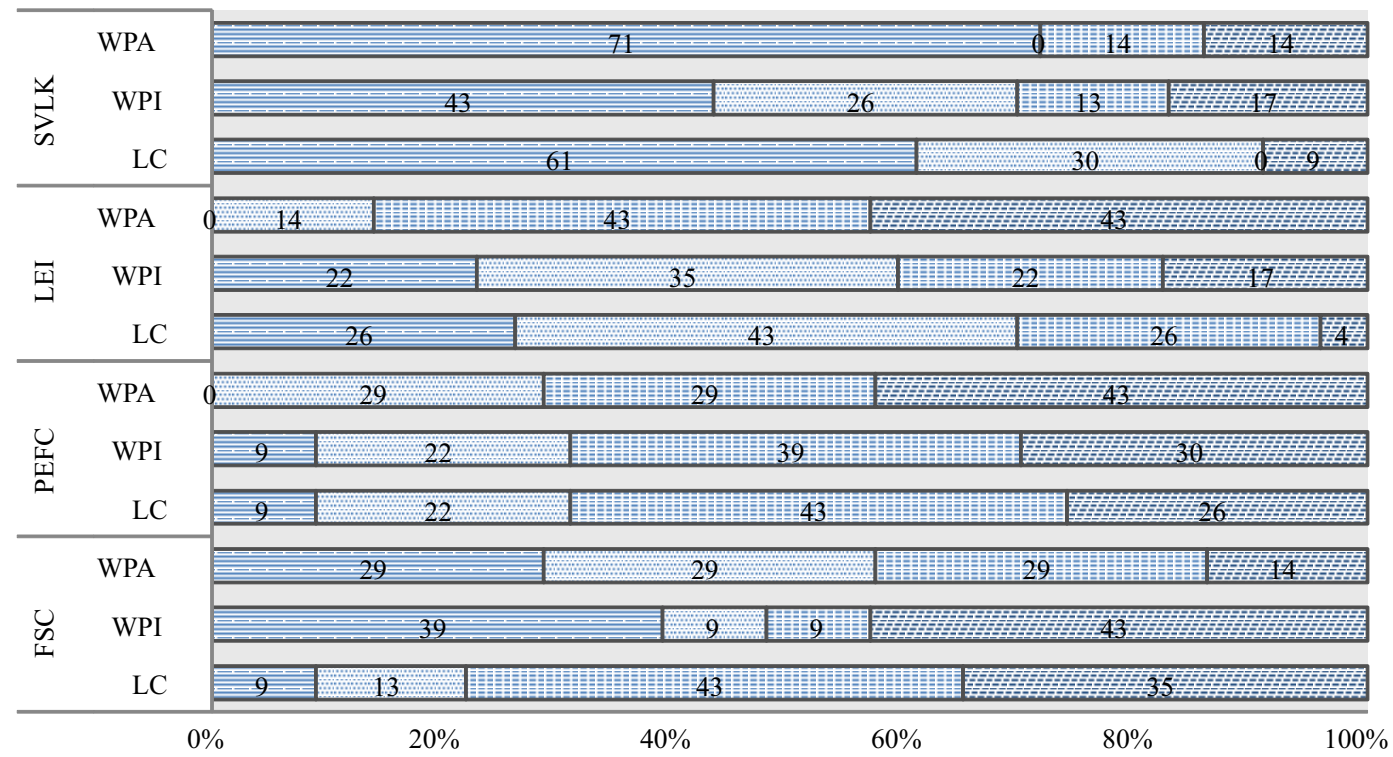

Figure 1 Difficulty of procuring certification, under specific schemes, according to stakeholder type. Very easy ( $\square$ ), easy (圆), intermediate (回), more dificult (回).

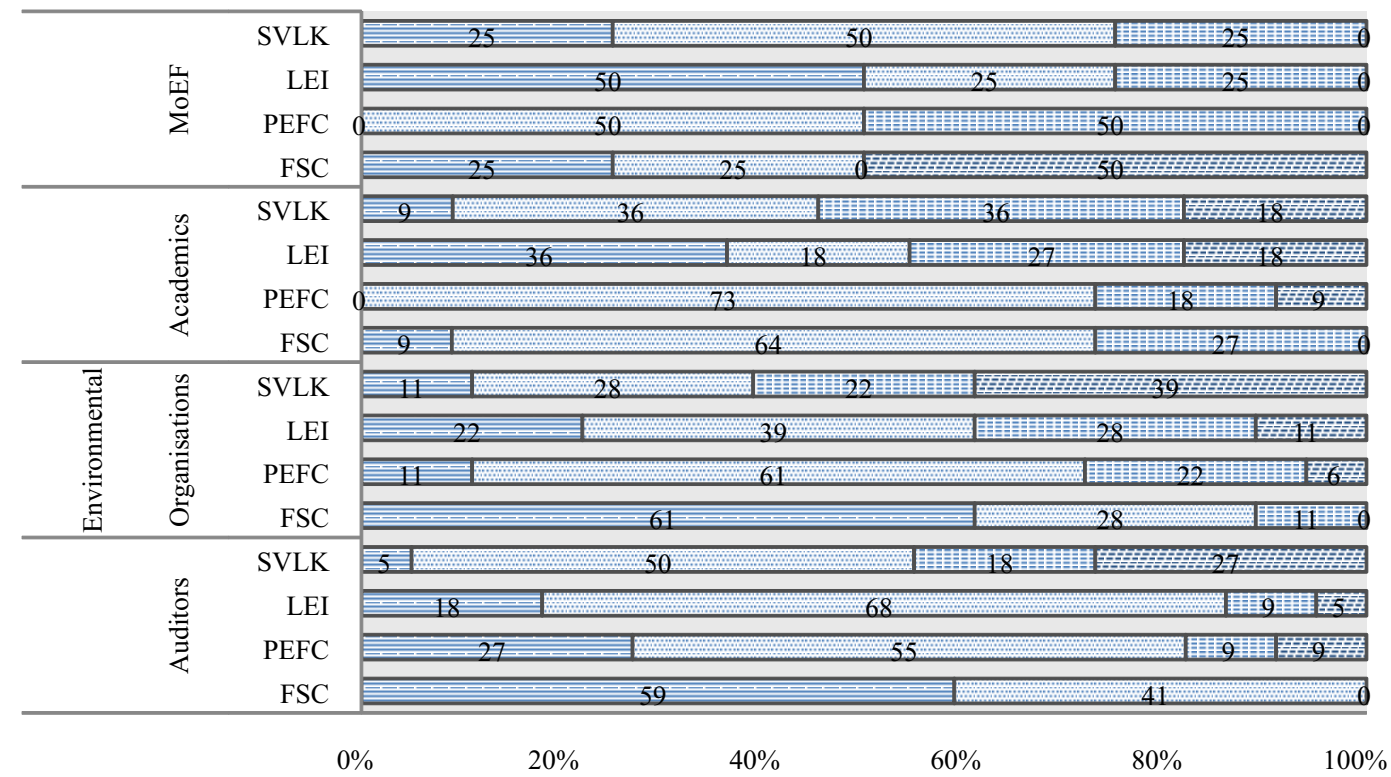

Figure 2 The perceived complexity of the schemes, according to stakeholder type. Very complex (目), Complex (圆), Intermediate (困), Simpler (国). 
interpretation of its standards and its strict evaluation system (Stewart et al. 2003). The PEFC and LEI have intermediate standards and the SVLK has lower standards for sustainable forest management. The LEI standard has detailed requirements and its decision-making process (using AHP) is quite complicated. The SVLK is considered to be the least complicated scheme, since it only requires the presentation of documents establishing legality.

Quality of standards The 4 groups of respondents were of the opinion that the FSC has a higher quality of standards than other schemes (Figure 3). The FSC is known as the golden standard because of its high standards of environmental and social responsibility (Magin 2008). Respondents from the auditor group thought that the FSC (91\%) and PEFC (82\%) have higher standards for sustainable forest management (SFM) as compared to the LEI (68\%) and SVLK (46\%). Quite different results arise from environmental organisations, where about $83 \%$ and $73 \%$ of the respondents say that the FSC and LEI, respectively, have higher standards for SFM than PEFC (44\%) and SVLK (11\%). A similar result can be observed for the group of academics, for whom the FSC (72\%), PEFC (72\%) and LEI (54\%) had higher standards than the SVLK (36\%). In contrast, respondents from the MoEF opined that the PEFC (75\%) and LEI (75\%) have higher standards than the FSC (50\%) and SVLK $(50 \%)$.

The schemes preferred by customers of timber producers The schemes preferred by customers differ according to the type of respondent (Figure 4). Logging company respondents convey that their customers prefer FSC and SVLK schemes to those of the PEFC and LEI. Something similar happens in the industry group, where $56 \%$ of the respondents express that their customers prefer FSC most often. The FSC was selected by timber producers' customers due to its well-known reputation, internationally-market

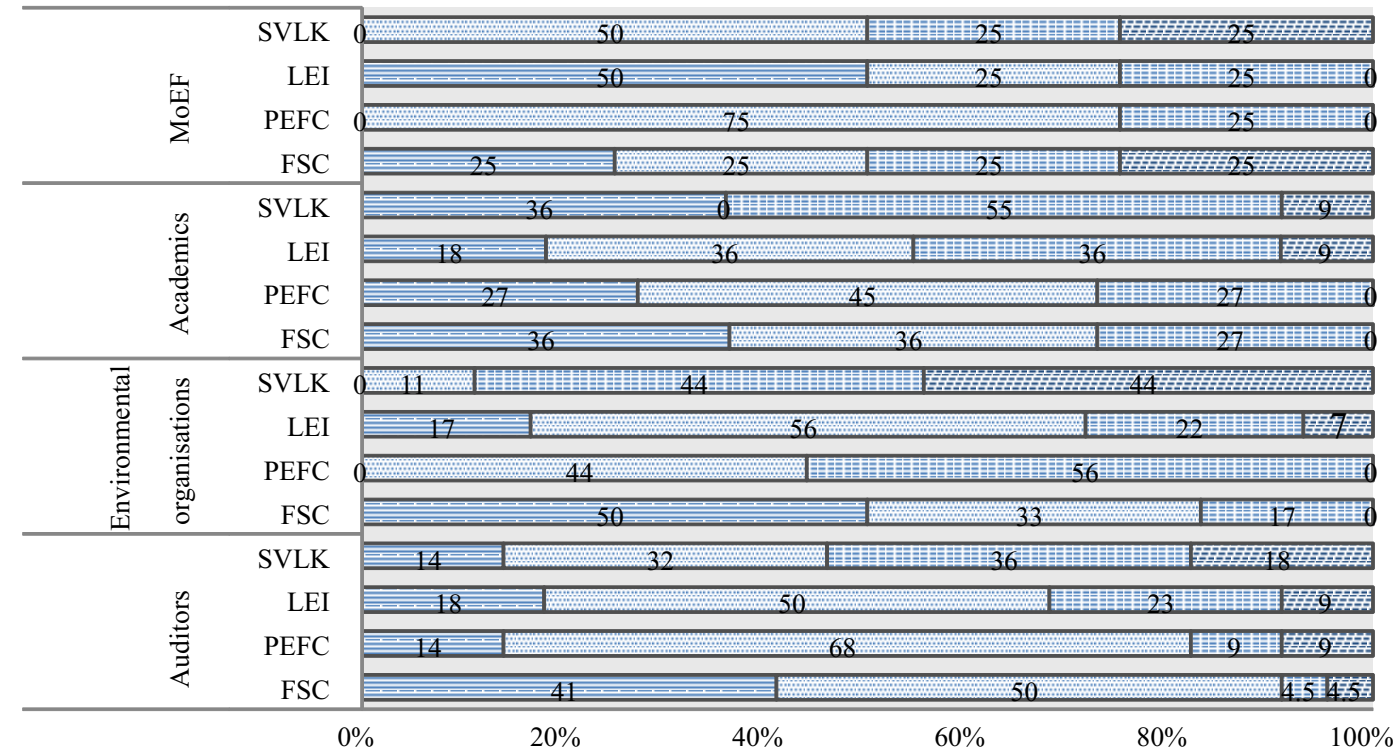

Figure 3 The quality of each scheme's standards, according to stakeholder type. Very high (国), high (圆), intermediate (国), low (国).

Wood Processing Associations

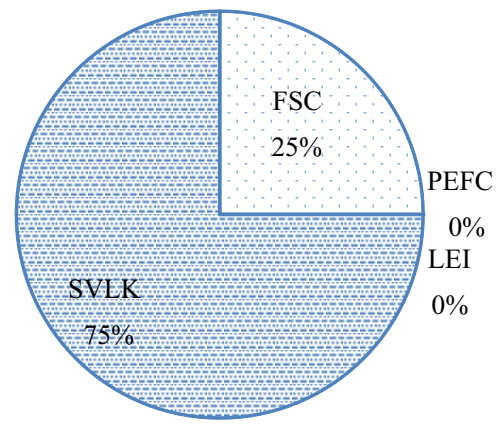

Logging Companies

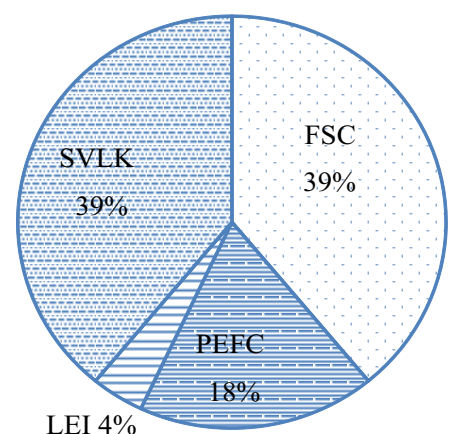

LEI $4 \%$

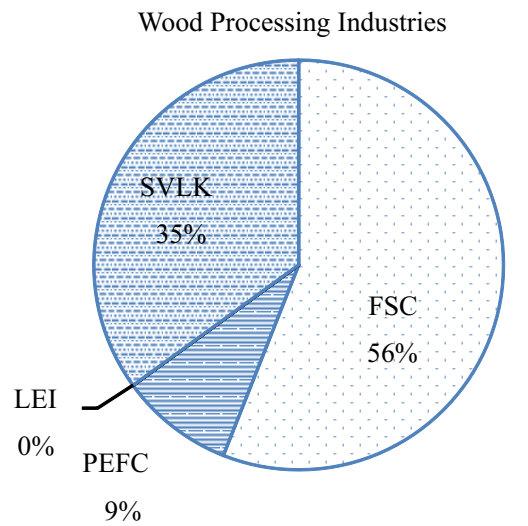

Figure 4 The schemes preferred by the customers of each stakeholder type. 
acceptance, and because no buyers reject. LEI has detailed standards that are suitable for SFM in Indonesia. However, respondents convey that there is a lesser demand for LEI among customers than there is for other schemes. A respondent from the industry group said that he did not want to engage with the LEI, as it has complicated requirements and is not accepted worldwide (it is only accepted in some countries). Even though LEI-certified products are accepted in Japan, Belgium, French, Italy, Spain, Finland and US (Purbawiyatna \& Simula 2008), the development of LEI certification tended to stagnate in the last 5 years. Wibowo et al. (2014) revealed that LEI's weaknesses originate from its narrow acceptance by buyers, its ineffective form of organisation and the penetration by stronger schemes.

The schemes demanded by the end buyer The four groups of respondents indicated that end buyers prefer the FSC and PEFC as compared to LEI and SVLK (Figure 5). The respondents from the auditors group express that the FSC $(96 \%)$ and PEFC $(72 \%)$ have a higher market demand than the SVLK $(50 \%)$ and LEI (9\%). A similar opinion came from environmental organisations, where the respondents convey that the FSC (72\%) and PEFC (50\%) have a higher demand than do the SVLK (12\%) and LEI (11\%). The respondents from the academics group have a different view, where $82 \%$ and $63 \%$ of them say that the FSC and SVLK, respectively, have higher market demand than do the PEFC (45\%) and LEI $(18 \%)$. The respondents from the MoEF share the opinion of the auditor and EA groups, where all of them (100\%) convey that the FSC and PEFC schemes have a higher market demand than do the SVLK and LEI. However, according to the respondents, the certification only belongs in the international market, and the local market has not really been made aware of the certified and non-certified products. According to a survey by Elliot (2014) in North Carolina, consumers are generally unaware of the concepts of forest certification and certified products.

The schemes that help the sustainability of logging and of wood processing industries Almost all respondents from the 4 different groups acknowledge that the FSC and PEFC are schemes that are more helpful to the logging companies than are the LEI and SVLK (Figure 6). In the group of auditors, about $91 \%$ and $78 \%$ of respondents expressed that the FSC and PEFC are more helpful than are the SVLK (54\%) and LEI (50\%). Similarly, environmental organisations express that the FSC (83\%) and PEFC (55\%) are more helpful than the SVLK (50\%) and LEI (39\%). The results are quite even across the schemes for the group of academics, where a total of $81 \%, 72 \%, 63 \%$ and $63 \%$ of respondents consider the FSC, PEFC, LEI and SVLK, respectively, to be the helpful scheme. In contrast with the other groups, the respondents from the MoEF stated that the SVLK is more helpful when compared to FSC, LEI and PEFC. According to a study by Nukpezah et al. (2014), about $63 \%$ of logging companies in Cameroon are certified by FSC. The main incentives for pursuing FSC certification were easy penetration into international markets, tax holiday benefits and the enhancement of the corporate image of the logging companies through corporate social responsibility fulfilments.

Image branding of the schemes About $100 \%$ and $82 \%$ of the respondents from the auditors group, respectively, express that the FSC and PEFC provide better image branding than the SVLK (46\%) and LEI (8\%) (Figure 7). Something similar happens with environmental organisations, where $89 \%$ and $61 \%$ of respondents reported that FSC and PEFC, respectively, have good image branding, while only $22 \%$ and $22 \%$ said the same about SVLK and LEI, respectively. In the group of academics, $91 \%$ of respondents said that the FSC

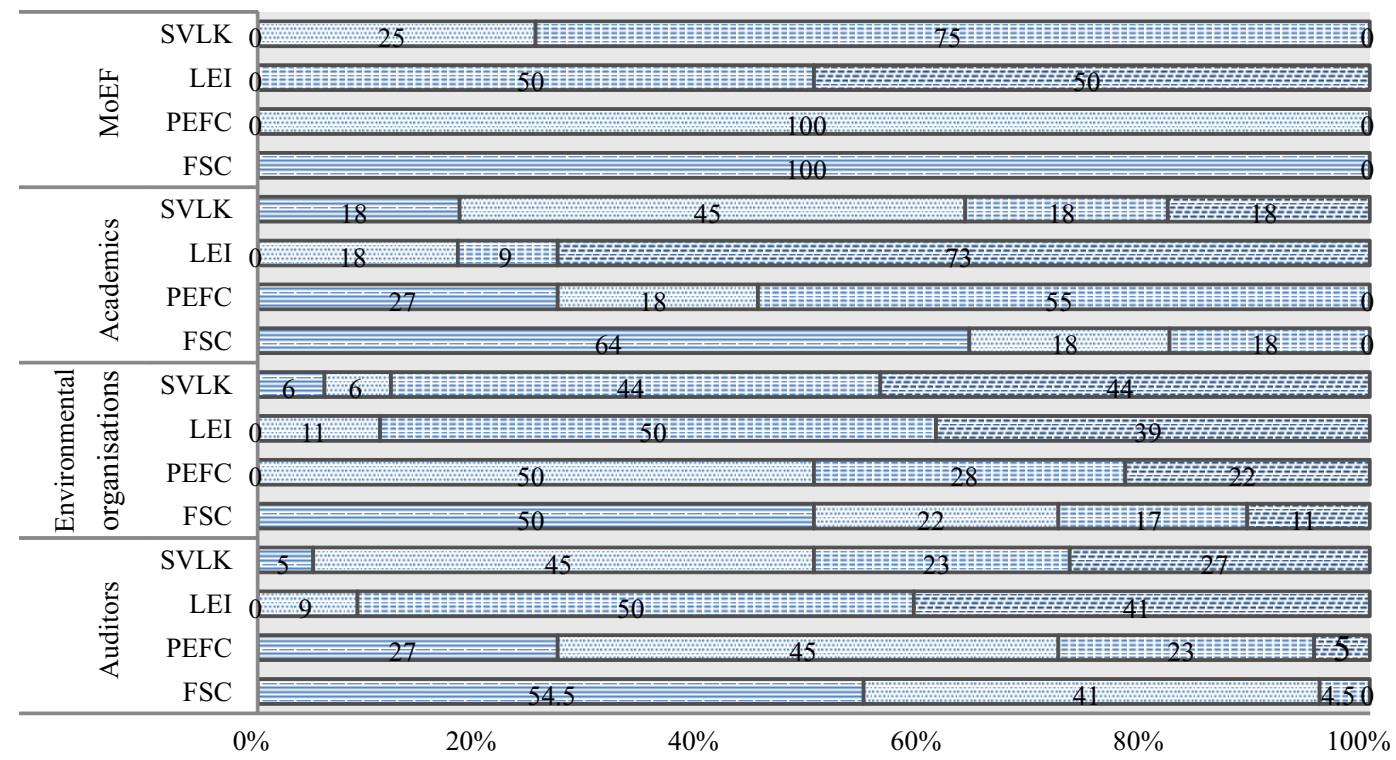

Figure 5 End buyers' demand for different schemes, according to stakeholder type. Very high (目), high (圆), intermediate (国), low (国). 


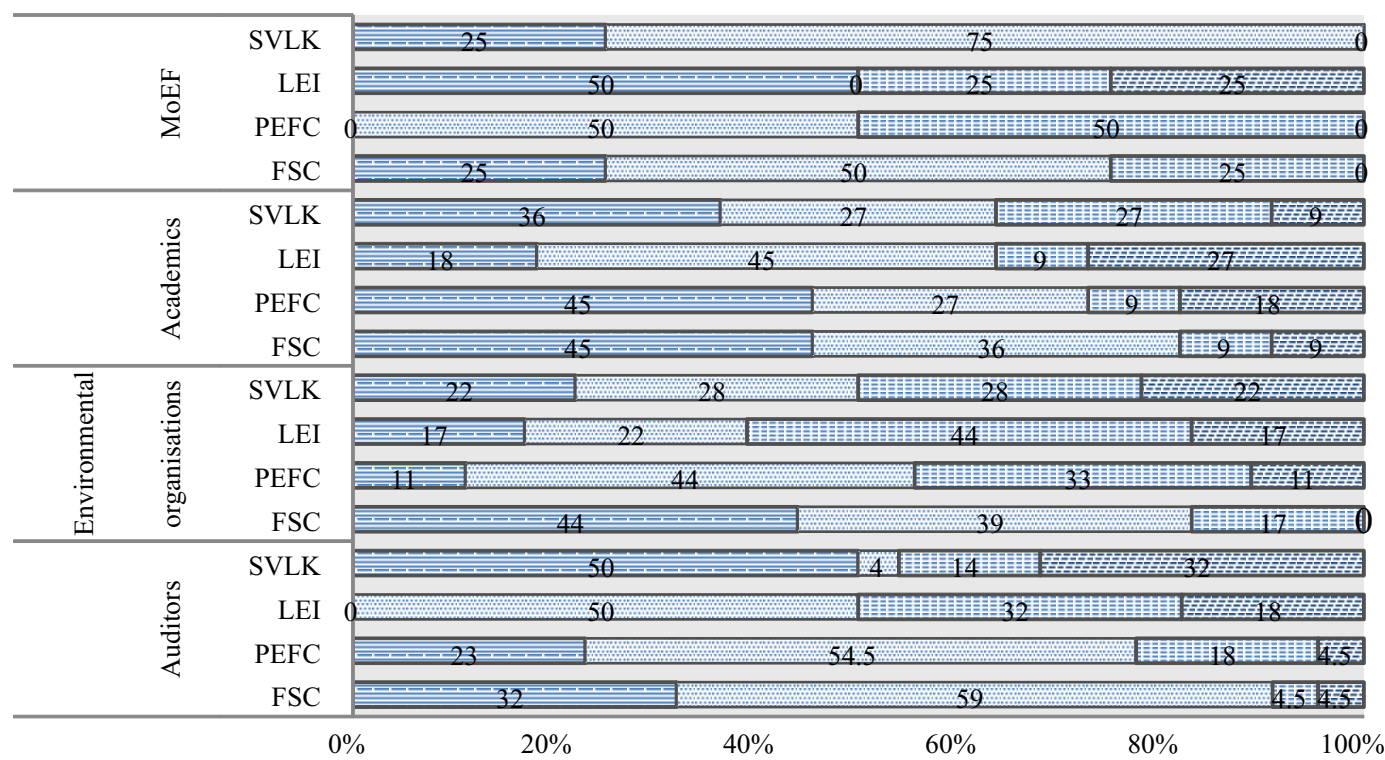

Figure 6 Schemes' support for the sustainability of logging and industry, according to stakeholder type. Very supportive (目), supportive (圖), intermediate (国), less supportive (国).

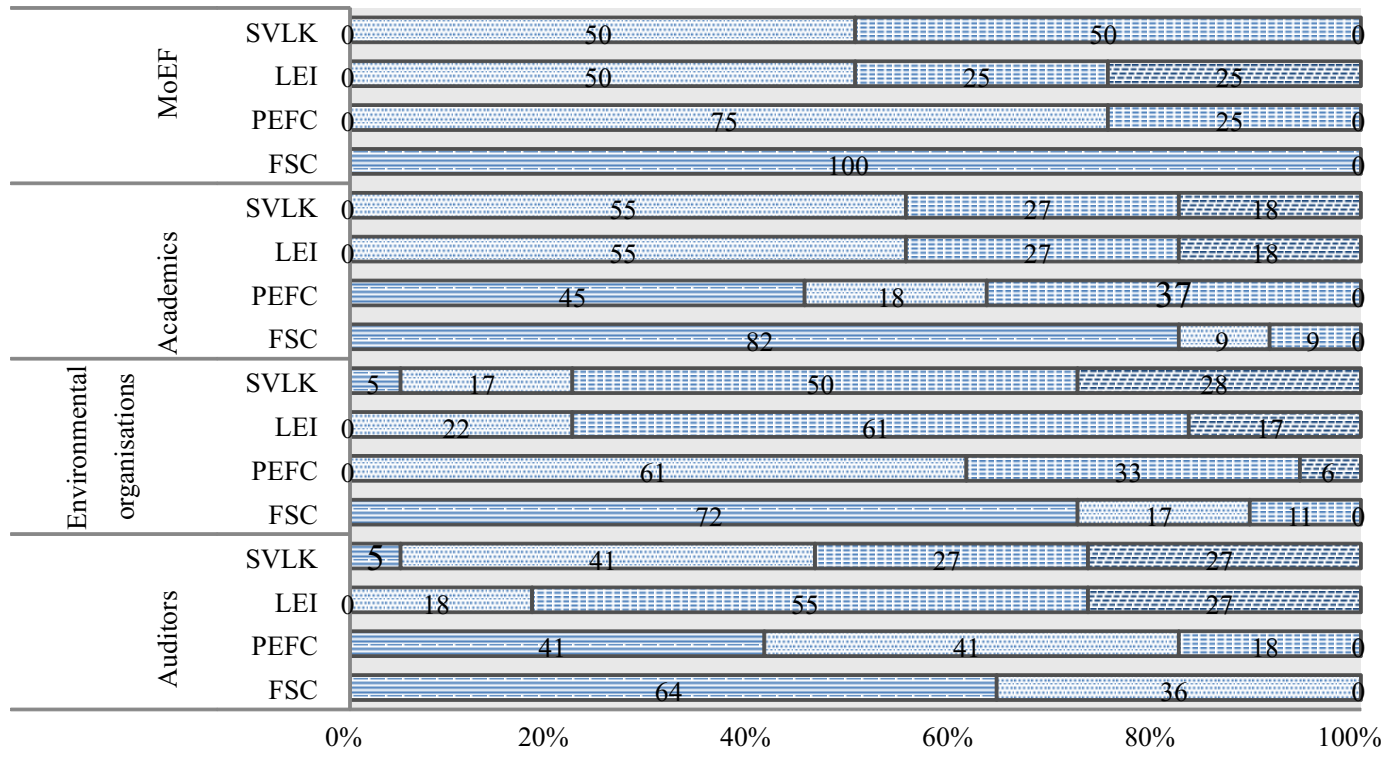

Figure 7 The perception of image branding for each scheme, according to stakeholder type. Very good (目), good (䧃), intermediate (国), low (国).

has the best image branding, followed by the PEFC (63\%), SVLK (55\%) and LEI (55\%). The MoEF also showed similar results, where $100 \%$ and $75 \%$ of respondents acknowledge that the FSC and PEFC, respectively, have good image branding. Research has shown that FSC certification can achieve improved market access, higher revenues, and an enhanced public image (Fonseca 2006).

The suitability of the schemes to Indonesia's conditions About $82 \%$ and $77 \%$ of respondents from the auditors group said that the LEI and SVLK are more suitable to Indonesia than are the PEFC (68\%) and FSC (63\%) (Figure 8). As a national scheme, LEI and SVLK standards fulfil government regulations, adapt to local conditions and are compliant with international standards. Something similar can be seen in the environmental organisations, where $89 \%$ of respondents express that the LEI is more suitable than SVLK (61\%), FSC $(56 \%)$ and PEFC (45\%). In the group of academics, the respondents said that the SVLK $(91 \%)$ and LEI $(90 \%)$ are more suitable than the other two schemes, PEFC (46\%), and FSC (37\%). Similarly, in the MoEF group, $100 \%$ of respondents believe that the LEI and SVLK are more suitable than the PEFC and FSC.

The LEI is the most suitable than the PEFC and FSC. The LEI is the most suitable scheme for Indonesia according to the stakeholders as a whole, followed by the SVLK. The LEI 
has produced high quality documentation of its extensive and carefully structured systems for forest certification (Hinrichs 2005). LEI standards are specific to local conditions and have strong national stakeholder support (Maryudi 2009). IFCC standards are also suitable to the plantation forests in Indonesia and more flexible than those of the FSC. The PEFC, LEI and SVLK focus more on implementing the CoC system with forest conservation, which is limited in FSC, making them therefore more suitable to be applied within the competition in business/industry. With its harmonisation standards, the FSC is not easier to apply. One respondent said the harmonisation standards are helpful, but some verifiers are not applicable to forest management in Indonesia, such as the requirements of High Conservation Value Forests (HCVF), non-timber product management, and worker regulations.

Forest certification caters to many peers and their respective interests (Rametsteiner \& Simula 2003). By obtaining certification, manufacturers are more likely to maintain their current markets (the alternative being to lose

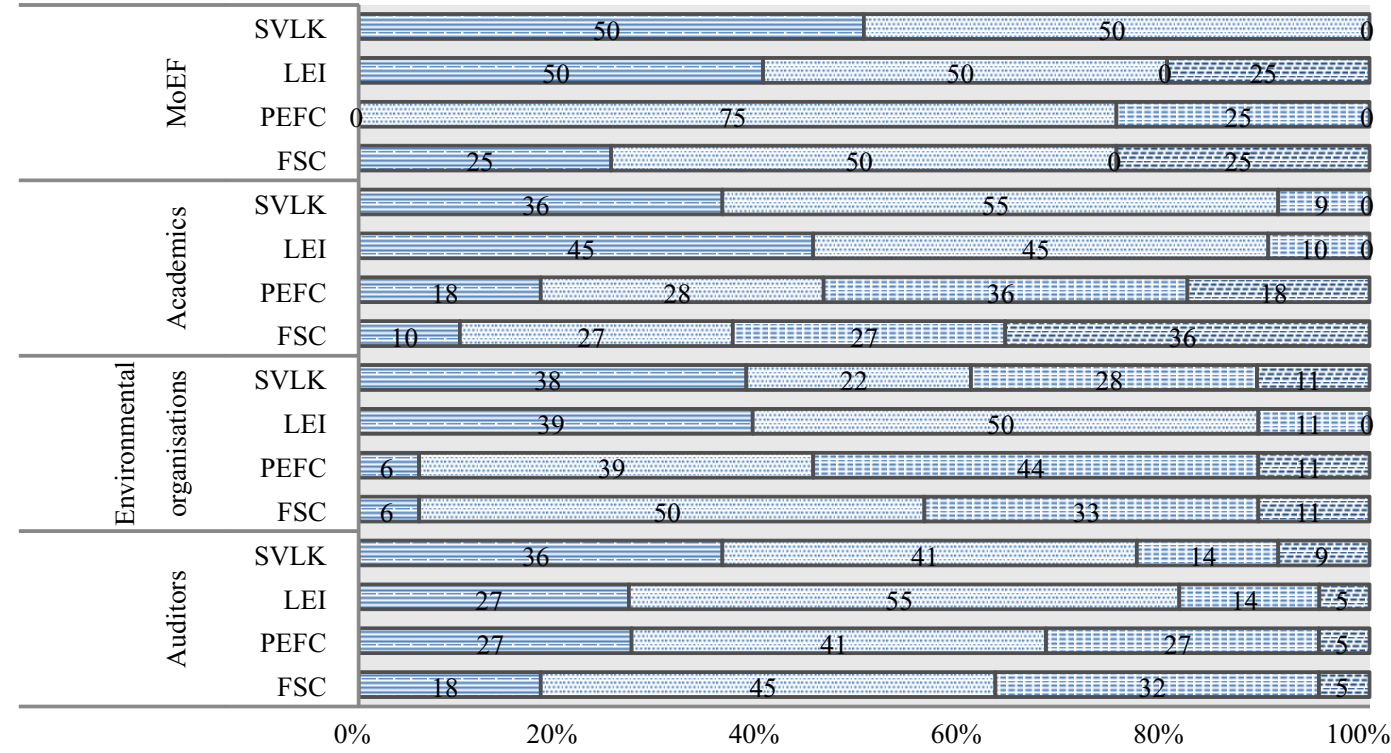

Figure 8 The suitability of each scheme to conditions in Indonesia. Most suitable (目), suitable (圖), intermediate (国), Less suitable preferred(国).

Wood processing associations

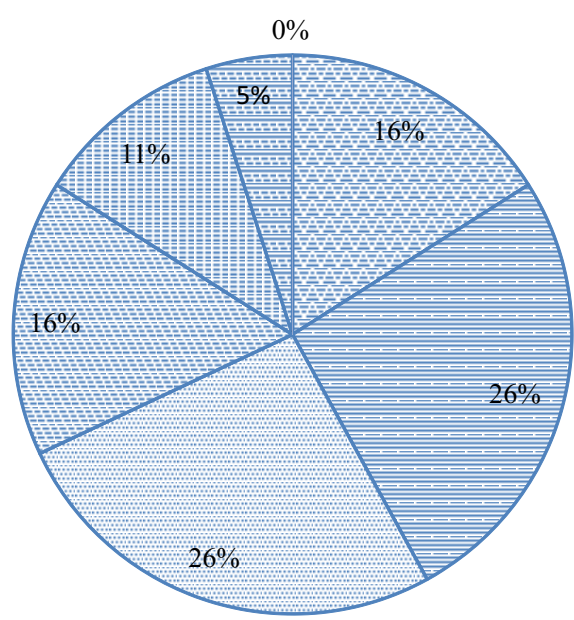

Logging companies

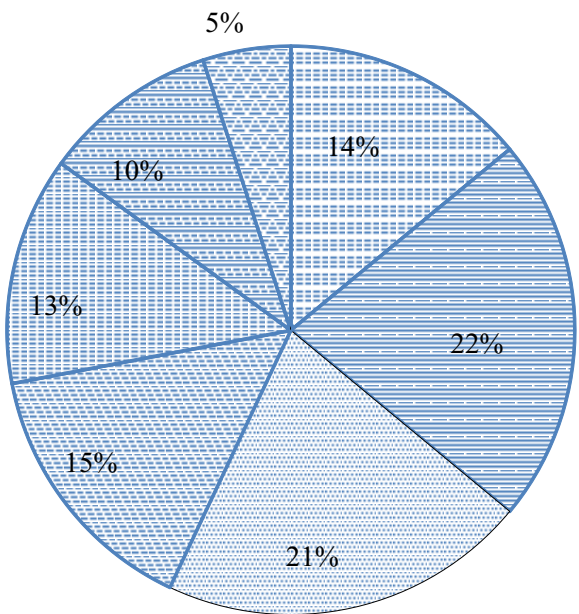

Wood procesing industry

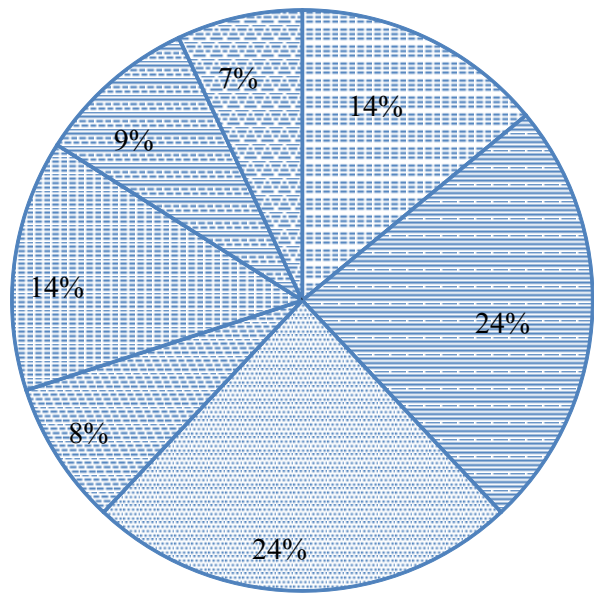

Figure 9 The motivation for pursuing certification. Preferred by business partner (国), support for environment and social aspects (圈), Scheme credibility (围), recommended by NGO ( $\square$ ), Image branding (目), Mandatory/government product (国), Suitable with company profile(国), 
them) or enter a new, more environmentally-conscious market (Chen at al. 2011). Figure 9 shows that an improved market and image branding is the main motivation of respondents for procuring certification (similar result to a study by Bowers et al. 2012). Image branding and support for the environment and society were the main motivations for respondents from the WPA group for seeking certification $(26 \%)$. Other reasons are the preferences of business partners, mandatory requirements and scheme credibility and suitability to the company profile. Similar trends happen in the group of logging companies, where $22 \%$ and $21 \%$ of respondents stated that image branding and support for the environment and society were the main motivations. Other motivations were mentioned, namely mandatory requirements, preferences of business partners, scheme credibility, and suitability to the company profile. Astana et al. (2014) show that companies that are involved in voluntary certification see it as a marketing strategy, due to the limited amount of available certified wood. Opinions from the WPI group show the same result, where $24 \%$ of respondents express that image branding and support for the environment and society are the main motivations for becoming certified. Other motivations account for less than $20 \%$ each, namely scheme credibility, preference of business partners, mandatory requirements, and suitability to the company profile. There are also other reasons mentioned by the respondents, such as specific wood, international rules and clear indicators and criteria. Interestingly, $17 \%$ of respondents from logging companies and WPI mentioned that recommendations from environmental organisations also increase their motivation to become certified.

The scheme preferences based on stakeholder interests As can be seen in Figure 10, about $78 \%$ and $61 \%$, respectively, of the respondents from the logging company group indicate that SVLK and LEI are preferred over FSC $(61 \%)$ and PEFC (52\%). The industry group shows a different trend, with $65 \%$ and $57 \%$ of respondents expressing their preference for FSC and SVLK, respectively, while the other $35 \%$ and $26 \%$ prefer PEFC and LEI, respectively. Similarly as with the logging company group, the respondents from the wood processing association group preferred SVLK (86\%) and FSC (71\%) to PEFC (67\%) and SVLK $(43 \%)$. In addition to it being easy and cheap to obtain, another reason for selecting SVLK is because it is a mandatory system, and it is obligatory for them to use it. The standards for the SVLK are achievable for the conditions of forest management in Indonesia. The government supports the implementation of SVLK by providing a guidance manual and public consultation. The reason for preferring the FSC is because it is accepted in markets worldwide, even if its standards are more complicated. The FSC may be an attractive marketing imperative for companies that seek to penetrate markets in the logging industry (Nukpezah et al. 2014). In Indonesia, the FSC is considered to be closer to natural forest management and community forestry (small holders). The FSC scheme, as the most satisfactory scheme from the point of view of end consumers, on the other hand, needs to adopt local business customs to increase its acceptance by domestic industries (Klassen et al. 2014, Hajjar 2013). On the other hand, the wood processing group preferred PEFC and SVLK to FSC and LEI. Almost no respondents preferred LEI as their scheme because of its complexity and low demand.

\section{Conclusion}

Respondents' feedback on our questionnaire can illustrate how Indonesian stakeholders, mainly in the business sector, recognise four forest certification schemes currently used in Indonesia. In general, respondents consider SVLK to be the easiest scheme to obtain certification, and the most indemand by industries. The reasons for choosing SVLK are: (i) standards suited to forest management practices in Indonesia, (ii) the requirements are easy to fulfil and

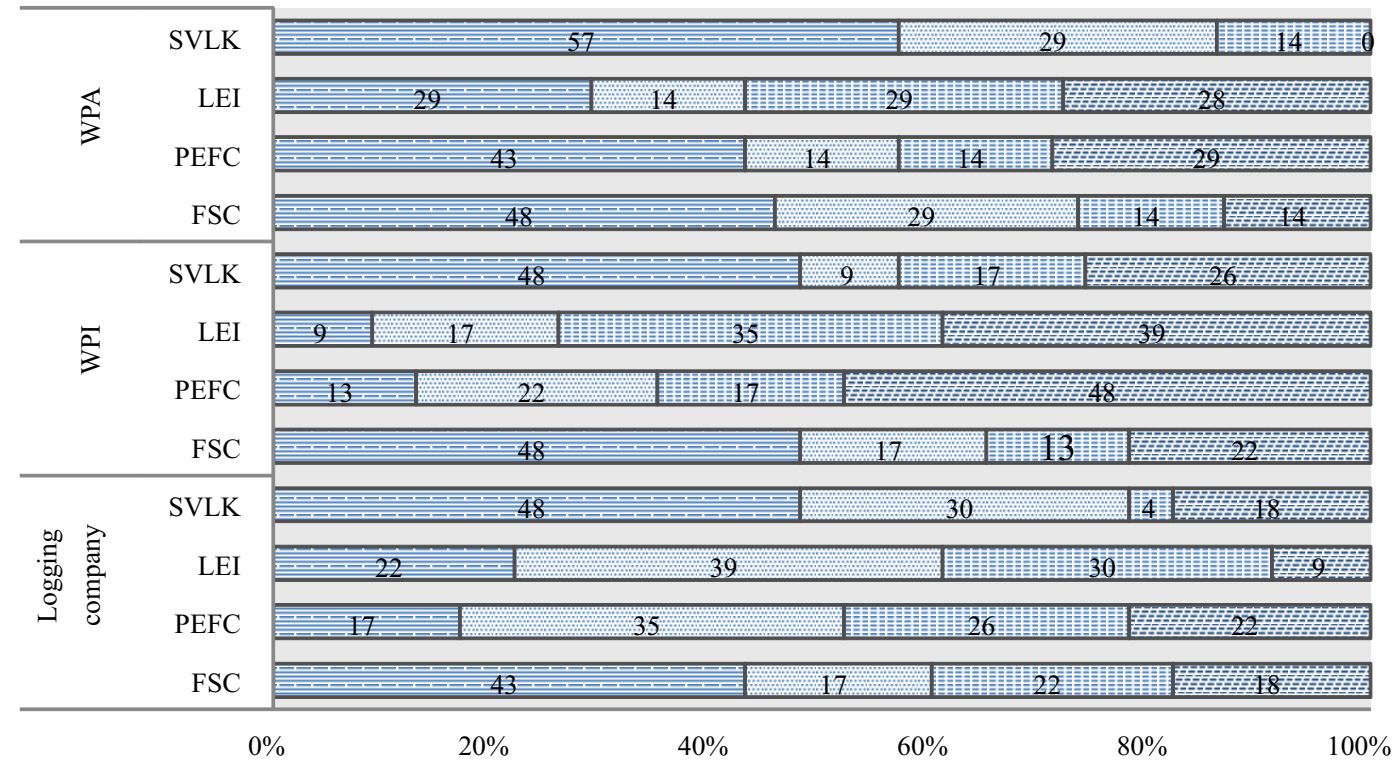

Figure 10 The scheme preference according to actor type. Most preferred (目), Preferred (圆), Intermediate (国), Least preferred (国). 
Table 1 Key features of stakeholders' recognition of and preferences for certification and timber legality systems

\begin{tabular}{lcccc}
\hline \multicolumn{1}{c}{ Key features } & & \multicolumn{2}{c}{ Ranking } & \\
\cline { 2 - 5 } & 1 & 2 & 3 & PEFC \\
\hline Ease of procurement & SVLK & LEI & FSC & SVLK \\
Complexity of requirements & FSC & PEFC & LEI & SVLK \\
Quality of standards & FSC & PEFC & LEI & LEI \\
Demand by customers of timber producer & SVLK & FSC & PEFC & LEI \\
Demand by end buyer & FSC & LEFC & PEFC & SVLK \\
Help to industries and logging companies & FSC & PEFC & SVLK & LEI \\
Good image branding & FSC & FSC & LEI & PEFC \\
Necessary for Indonesia's conditions & SVLK & SVLK & FSC & PEFC \\
Suitability for Indonesia's conditions & LEI & FSC & PEFC & LEI \\
Preferred by stakeholders & SVLK & & SEC
\end{tabular}

FSC $=$ Forest Stewardship Council, PEFC $=$ Programme for the Endorsement of Forest Certification, LEI $=$ Lembaga Ekolabel Indonesia, SVLK $=$ Sistem Verifikasi Legalitas Kayu

understand, (iii) the government has made it mandatory, (iv) there are enough certification/verification bodies, and (v) the low cost of the certification process and the availability of subsidies. In contrast, the FSC was identified as the most costly scheme with the most requirements and the most complex standards, but also as the most often demanded by the customers. In brief, the SVLK is evidently preferred by industries for economic and technical reasons, while FSC is preferred due to its good image branding and wide market acceptance. However, this view has to be analysed further to determine whether it is really based on experience or whether it is the result of the influence of the promotion of the FSC by environmental organisations like Greenpeace, the WWF, and others, which regularly produce material that presents the FSC in a positive light. The respondents placed the LEI in between these two schemes, by characterising it as having high standards, a low market demand, complex requirements and a high cost. Although the PEFC scheme is quite new in Indonesia and there are no reports on the companies that have been certified using it, respondents acknowledge that the PEFC is a forest certification scheme with high standards. Surprisingly, the LEI, which most stakeholders do not prefer, was chosen as being the most suitable scheme for sustainable forest management in Indonesia, followed by the SVLK. Both are national forest certification initiatives.

\section{Recommendation}

The existence of many third-party forest certification schemes opens up opportunities for the timber industries to choose the most suitable for them. However, financial constraints, the export orientation and the compulsory nature of the SVLK mean that this selection is not always easy. To overcome this complexity, the Ministry of Environmental and Forestry needs to improve the SVLK continually to maintain its status as a credible scheme, ensuring it aims to better forest governance. Comprehensive and proper responses to any objections about the implementation of
SVLK and its certification processes should be properly addressed by the government. The FSC and SVLK should be allowed to compete freely and have the same chances to gain broader market recognition. In addition to these wellestablished schemes, the LEI and PEFC are still necessary as an alternative and counterweight for the appropriate enterprises. Synchronization or mutual recognition of the schemes could be more profitable for the forest industries and could help avoid the cost of multiple certifications

\section{Acknowledgment}

The Indonesian Ministry of Education and the German Academic Exchange Service (DAAD) supported this research financially. We sincerely thank $\mathrm{Mr}$ Hartono Prabowo, Mr Lisman Sumardjani, and $\mathrm{Mr}$ Alan Purbawiyatna, from the Directorate General of Forest Utilization at the Ministry of Environment and Forestry, for their valuable information, which was a great contribution to this article.

\section{References}

Astana S, Obidzinski K, Riva WF, Hardiyanto G, Komarudin H, Sukanda. 2014. Cost and benefit implications of SVLK implementation to small-scale timber sector. Jurnal Penelitian Sosial dan Ekonomi Kehutanan 11(3):175-198.

Bowers T, Eastin I, Ganguly I, Cao J, Seol M. 2012. Forest certification in Asia: The changing marketplace for valueadded wood product manufacturers in China and Vietnam. The Forestry Chronicle 88(5):578-584. http://dx.doi.org/10.5558/tfc2012-109.

Chen J, Innes JL, Kozak RA. 2011. An exploratory assessment of the attitudes of Chinese wood products 
manufacturers towards forest certification. Journal of Environmental Management 92:2984-2992. http://dx. doi.org/10.1016/j.jenvman.2011.07.012.

Elliot J. 2014. An analysis of willingness to pay and reasons for purchasing certified forest products. [Thesis]. North Carolina: The Nicholas School of the Environment of Duke University.

Faggi AM, Zuleta GA, Homberg M. 2014. Motivations for implementing voluntary environmental actions in Argentine forest companies. Land Use Policy 41:541-549. http://dx.doi.org/10.1016/j.landusepol.20 14.04.011.

Fonseca SA. 2006. Forest certification in Mexico. In: Cashore B, Gale F, Meidinger E, Newsom D, editors. Confronting sustainability: Forest certification in developing and transitioning countries. New Haven: Yale Publishing Services Center.

[FSC] Forest Stewardship Council. 2008. Facts and figures on FSC growth and markets. [download] http://www.ipef.br/pccf/artigos/FSC_Fatos_e_Mercado _Fev_2008_Ingles.pdf.

[FSC] Forest Stewardship Council. 2014. Global FSC certificates: type and distribution. [download] https://ic.fsc.org/preview.facts-and-figures-november2014.a-3810.pdf.

Gulbrandsen, L. 2003. The evolving forest regime and domestic actors: strategic or normative adaptation?. Environmental Politics 12(2):95-114. http://dx.doi.org/ 10.1080/09644010412331308204.

Gulbrandsen LH. 2004. Overlapping public and private governance: Can forest certification fill the gaps in the global forest regimes? Global Environmental Politics 4(2):75-99. http://dx.doi.org/10.1162/1526380043230 74200 .

Hansen E, Fletcher R, Nikinmaa H. 2005. Forest certification and small forest enterprises: key trends and impacts, benefits and barriers. Washington, DC: Forest Trends.

Haufler V. 2003. New forms of governance: certification regimes as social regulations of the global market. Social and political dimensions of forest certification 237-247.

Hinrichs A. 2005. Lembaga Ekolabel Indonesia-Introduction and implementation of forest certification in Indonesia. In: Burger D, Hess J, Lang B, Editors. Forest Certification: An innovative instrument in the service of sustainable development?, Eschborn, Germany: Deutsche Gesellschaft für Technische Zusammenarbeit (GTZ). pp.135-153.

Krott M. 2005. Forest Policy Analysis. Springer, Dordrecht.
[LEI] Lembaga Ekolabel Indonesia. 2014. Laporan Kegiatan Lembaga Ekolabel Indonesia 2009-2014. LEI.

Leslie AD. 2004. The impacts and mechanics of certification. International Forestry Review 6(1):30-39. http://dx.doi. org/10.1505/ifor.6.1.30.32064.

Lozano R. 2013. A holistic perspective on corporate sustainability drivers. Corporate Social Responsibility and Environmental Management 22:32-44. http://dx.doi. org/10.1002/csr.1325.

Magin G. 2008. Forest Certification: What does it mean for the world's forests?. Botanic Gardens Conservation International 5(1). Available online: http://www.bgci.org resources/article/0579/.

[MoEF] Ministry of Environment and Forestry. 2012. Minister Regulation No. 95/Menhut-II/2012. Standards and guidelines on implementation of performance assessment of sustainable management of production forest and timber legality assurance system (SVLK). Jakarta: Ministry of Environment and Forestry.

Nukpezah D, Alemagi D, Duguma L, Minang P, Mbosso C, Tchoundjeu Z. 2014. An examination of forest certification status among logging companies in Cameroon. Internationan Scholarly Research Notices 2014. Article ID: 323014.

Nurrochmat DR, Dharmawan AH, Obidzinski K, Dermawan A, Erbaugh, JT. 2014. Contesting national and international forest regimes: Case of timber legality certification for community forests in Central Java, Indonesia. Forest Policy and Economics http://dx.doi. org/10.1016/j.forpol.2014.09.008.

Nussbaum R, Simula M. 2005. The Forest Certification Handbook. London: Earthscan.

Obidzinski K, Dermawan A, Andrianto A, Komarudin H, Hernawan D. 2014. The timber legality verification system and the voluntary partnership agreement (VPA) in Indonesia: Challenges for the small-scale forestry sector. Forest Policy and Economics 48:24-32. http://dx.doi. org/10.1016/j.forpol.2014.06.009.

[PEFC] Programme for the Endorsement of Forest Certification. 2014, November. PEFC global statistics: $S F M$ \& $C o C$ certification. Available online: http://www.pefc.org/about-pefc/who-we-are/facts-afigures.

Purbawiyatna A, Simula M. 2008. Developing forest certification: towards increasing the comparability and acceptance of forest certification systems worldwide. International Tropical Timber Organization. Yokohama, Japan.

Rametsteiner E, Simula M. 2003. Forest certification-an instrument to promote sustainable forest management. Journal of Environmental Management 67:87-98. 
http://dx.doi.org/10.1016/S0301-4797(02)00191-3.

Sahide MAK, Nurrochmat DR, Giessen L. 2015. The regime complex for tropical rainforest transformation: Analysing the relevance of multiple global and regional land use regimes in Indonesia. Land Use Policy 47:408-425. http://dx.doi.org/10.1016/j.landusepol.2015.04.030

[SILK] Sistem Informasi Legalitas Kayu. 2014. List of certificate holders. Available online: www.silk.dephut. go.id/index.php/info/iuiphhk.

Steffek J. 2009. Discursive legitimation in environmental governance. Forest Policy and Economics 11(5):313-318. http://dx.doi.org/10.1016/j. forpol. 2009.04.003.

Stewart J, Robinson D, Brown L. 2003. Increasing FSC certification for small and low intensity managed forests. Proceedings of XII World Forestry Congress, Quebec, Canada.

Taylor PL. 2005. In the market but not of it: Fair trade coffee and forest stewardship council certification as market- based social change. World Development 33(1):129-147. http://dx.doi.org/10.1016/j.world dev.2004.07.007.

Thornber K, Plouvier D,Bass S. (1999). Certification: Barriers to benefits. European Forest Institute.

Tuppura A, Toppinen A, Puumalainen K. 2015. Forest certification and ISO 14001: Current state and motivation in forest companies. Business Strategy and the Environment.

Upton C, Bass S. 1995. The Forest Certification Handbook. London: Earthscan.

van Kooten GC, Nelson HW, Vertinsky I. 2005. Certification of sustainable forest management practices: a global perspective on why countries certify. Forest Policy and Economics 7(6):857-867. http://dx.doi.org/10.1016/ j.forpol.2004.04.003.

Wibowo A, Sahide MAK, Pratiwi S, Dharmawan B, Giessen L. 2014. Positioning LEI among certification schemes and developing options for its transformation. Paper presented at the Third Congress of the Indonesian Ecolabelling Institute, held in Bogor, 9 October 2014. 


\title{
Comparing Forest Certification and Timber-Legality Verification Systems in Indonesia: Complementary or Competitive?
}

\author{
Agung Wibowo ${ }^{1,3^{*}}$, Santi Pratiwi ${ }^{2,3}$, Lukas Giessen ${ }^{3}$ \\ ${ }^{1}$ Department of Forestry, Faculty of Agriculture, University of Palangka Raya, Kampus \\ UNPAR Tunjung Nyaho, Jl. Yos Sudarso PO BOX 2/PLKUP, 73111, Palangka Raya, \\ Indonesia \\ ${ }^{2}$ South Sumatera Nature Conservation Agency, Ministry of Environment and Forestry, \\ Jl.Kol.H.Burlian KM 6,5 Puntikayu, Palembang, Indonesia \\ ${ }^{3}$ Chair of Forest and Nature Conservation Policy, Georg-August-Universität Goettingen, \\ Buesgenweg 3, 37077, Goettingen, Germany \\ *Correspondence author, email: agung.wibowo@stud.uni-goettingen.de, Phone/Fax: +49 \\ (0)176 $79753530 /+49$ (0)5513933415
}

\section{Acknowledgments}

We gratefully acknowledge the support from the German Academic Exchange Service (DAAD), the Eva Mayr-Stihl Foundation, the German Research Foundation (PAK 813) and the Indonesian Directorate General of Higher Education (DIKTI). 


\begin{abstract}
Indonesian small-scale forest holders are facing a dilemma due to the implementation of a mandatory national timber- legality verification scheme and an internationally popular forest certification scheme. The problems arise from limited financial, technical, and administrative information concerning the most preferred scheme and the "imperfection of such a scheme" for long-term business needs. Using the Forest Certification Assessment Guide (FCAG) this paper identifies the characteristics of four third-party forest certification schemes currently working in Indonesia. An online questionnaire was used to survey a wide range of respondents about the future development of contested schemes and those preferred by small-scale forest holders. Our findings show that although the Forest Stewardship Council (FSC) scheme obtained the highest score and is considered the best scheme according to the FCAG, small-scale forest holders prefer the Indonesian timber legality verification system (SVLK), which had the lowest FCAG score because of its mandatory nature and available subsidies. Statements by the four schemes' proponents, which delegitimize other schemes, reveal they are in competition. Finally, we suggest proponents to enhance aspects where their schemes are lacking and contrive a comparable certification scheme in order to induce willingness to be certified.
\end{abstract}

Keywords: forest certification schemes; timber-legality system; comparison; FCAG; Indonesia

\title{
1 Introduction
}

Private and voluntary forest certification aiming to promote equitable social, environmental, and business outcomes in forest management is a new initiative in the private regulation of international timber product trade (Bartley 2003; Meidinger 2003; Cashore 2005) because of increased global concerns about forest degradation by massive forest operations. Timber-legality verification, on the other hand, is a state-based timber-legality measurement assembled under the Forest Law Enforcement Governance and Trade-Voluntary Partnership Agreement (FLEGT-VPA) between the European Union (EU) and governments of partner countries. This aims to ensure any timber products imported by and traded in EU countries have passed a set of criteria containing the agreed partner timber-legality assurance system (Wiersum and Elands 2013). Although forest certification and timber-legality verification have similar goals, namely to reduce forest degradation, maintain remnant natural forest, enhance local benefit, and promote the green economy (McDermott et al. 2015), both mechanisms are disparate in image, legitimacy, power (Berstein and Cashore 2004; McDermott 2012), and public acceptance. This makes decisions by timber and forest industries difficult (Overdevest and Zeitlin 2014).

On the timber-producer side, however, economic motives in joining forest-certification and legality-verification processes, which include fulfilling demands from business partner, marketing aspects, and improving product image and credibility are stronger motives than preserving the environment (FSC 2008; Lidestav and Lejon 2011; Crow 
and Danks 2010). Of course, the option to engage with a certification process could be taken only if long-term economic benefits gained by the producers are greater than ignoring it (Gulbrandsen 2003). Some studies (for example, Nurrochmat et al. 2014; Obidzinski et al. 2014; Harada and Wiyono 2014; He et al. 2015; Alemagi et al. 2012) reveal that reasons to participate in forest certification varies and are more complicated for the small-scale timber producer. This is due to their limited production scale, market orientation, and financial capacity for certification, traditional management, tenure uncertainty, lack of information, and the number of group certification members. Hence, accurate information about the comparison of forest certification and legality-verification schemes should assist potential firms in making a decision.

Taking its example from Indonesia, this paper compares three voluntary forest-certification schemes and one mandatory timber-legality verification scheme imposed by the government. Our objectives are to identify lead aspects of these schemes and whether these aspects are important for forestry firms. The results will provide an alternative source of claims concerning the veracity of schemes. Furthermore, we try to answer whether contesting schemes are working to achieving common goals or they are competing in capturing market share of forest/timber enterprises.

\section{History and current status of forest and timber certification in Indonesia}

Currently there are three voluntary private forest-certification schemes in Indonesia, namely the Forest Stewardship Council (FSC), the Programme for the Endorsement of Forest Certification (PEFC), and Lembaga Ekolabel Indonesia (LEI); and one mandatory state-based timber-legality verification system, Sistem Verifikasi Legalitas Kayu (SVLK). The first forest certification initiative under the FSC scheme was conducted in 1998. It successfully certified three out of five assessed Forest Management Units (FMUs) in Java. This was followed by six FMUs in Java, and one in Sumatera within the next two years. However, all certificates were suspended and withdrawn in 2003 due to unsatisfactory management and non-compliance with the FSC standard (Muhtaman and Prasetyo 2006). A new era of FSC standard based-certification began in 2008 when six FMUs managed areas of 707.709 hectares obtained certificates (FSC 2008). This grew to 2.002.710 hectares in 2014, representing a certified area of 29 FMUs (FSC 2014a). In the same period, the number of FSC Chain of Custody (CoC) certificates in Indonesia grew to 193 by December 2014 (FSC 2014a).

In 2014, the PEFC endorsed the Indonesian Forestry Certification Cooperation (IFCC) as its official national governing body in Indonesia. The IFCC is a national organization established on October 19, 2011, responsible for the development of forest certification in Indonesia using the PEFC scheme. The process for setting the IFCC certification standard started in 2012. Drafted in partnership with members of the standardization committee, it was approved by the IFCC board of directors in 2013, and submitted to the PEFC Council for endorsement in 2014. The IFCC subsequently released the standard for sustainable forest management and the chain of custody based on PEFC 
standards. Currently there is still no forest certified by PEFC/IFCC, and only $17 \mathrm{CoC}$ certificates were awarded by PEFC in Indonesia (PEFC 2014).

The development of the Indonesian certification system for natural forest as the embryo of LEI, its institutional arrangements, and other required supporting systems took place during 1994-1998. The process was led by Pokja Lembaga Ekolabel Indonesia (the LEI Working Group) involving a range of interest groups including the Association of Forest Concession Holders of Indonesia (APHI), an expert team, the National Standardization Board (BSN), NGOs, and university representatives (Purbawiyatna and Simula 2008). LEI standards for sustainable production forest management and its guidelines for implementation were approved and listed in the Indonesian National Standard and Guideline directory by the National Standardization Agency in 1998 (Suntana et al. 2000). LEI members were organized into four chambers representing all the relevant non-governmental stakeholder groups: NGOs, private sector, independent experts, and indigenous communities. The first certification process using the LEI standard was conducted in 1998, and PT Diamond Raya Timber, who managed 90.956 hectares of natural production forest, obtained the first certificate a year later (Muhtaman and Prasetyo 2006). LEI (2013) released FMU statistics of LEI certifications in the period 2004-2013 showing that were 1.873.428 hectare of forest areas, comprising 411.690 hectares of natural production forest (22\%) by two FMUs, 1.429 .055 hectares of plantation forest (76\%) managed by 15 FMUs, 32.683 hectares of community forest (2\%) by 22 community groups, and 6 CoCs already certified by July 2013.

SVLK is the Indonesian Timber-Legality Assurance System (TLAS) agreed under the FLEGT-VPA pact between Indonesia and the EU. The SVLK came into force in June 2009 when the Minister of Forestry (GoI) issued Regulation No.P.38/Menhut-II/2009 concerning standards and guidelines for performance assessment of sustainable forest management and timber-legality assurance. The four generic TLAS elements of the EU-FLEGT scheme are clearly addressed in the SVLK, which covered legal definitions, timber supply-chain control, verification, and independent monitoring. SVLK applies to all types of forest management in Indonesia: the production of natural forests, planted forests, community forests, and indigenous forests. It is based on management units or timber permit holders. In SVLK, there are two kinds of certificates: Sustainable Production Forest management or Pengelolaan Hutan Produksi Lestari (S-PHPL) and Sertifikat Legalitas Kayu (S-LK). S-PHPL (certificate for sustainable plantation forest management) applied to all forest concessionaires and FMUs in 2013. The PHPL-certified forests in 2013 comprise 14.379 .701 hectares, representing an area managed by 130 FMUs (CIFOR 2013). The S-LK (certificate for timber-legality) has been awarded to 766 companies (CIFOR 2013) since the government mandated FMUs and industries to have V-legal documentation, a sign specifies that exported timber products have met Indonesian timber legality requirements. In January 2015, the government fully implemented the SVLK with the issuance of Regulation P.95/Menhut-II/2014 (Hereinafter referred Regulation 95) of the Minister of Environment and Forestry (MoEF) and Regulation P.1/IV-BPPHH/2015 of the Director General of Forest Enterprises of the MoEF. Lately, the MoF worked together with the Ministry of Industry and the Ministry of Trade to simplify the requirements of the SVLK especially for small and medium companies. For small companies, the government subsidies the cost of certification and supplies a conformity declaration (export declaration) free of charge for a maximum of one year. 


\section{Methodology}

The Forest Certification Assessment Guide (FCAG) developed by the World Wide Fund for Nature (WWF) in collaboration with the World Bank (WWF and WB 2006) was used as framework in comparing the strength of forest sustainability certification and timber-legality verification schemes currently working in Indonesia. The FCAG consists of three parts, namely, (1) compliance with international norms and standards, (2) standards and the standard-setting process, and (3) conformity assessment, certification, and accreditation. Within these parts there are 11 criterion and 55 requirements based on the Global Forest Alliance requirements and criteria. The FCAG, which tends to financial institutions' views ${ }^{1}$, also acknowledges other existing standards for conformity assessment such as the International Organization for Standardization (ISO) or the International Social and Environmental Accreditation and Labelling (ISEAL) Alliance. Hence, although FCAG was formulated by the WWF, a proponent of FSC, one of certification scheme assessed in this study, the FCAG framework is internationally accepted and used by analysts (for example, Hinrichs and Prasetyo 2007; Maryudi 2009; Walter 2006; 2011) in comparing contested schemes.

In this study, each scheme (FSC, IFCC, LEI and SVLK) were analyzed against the requirements of the FCAG framework. Evaluation focused on forest management standards and systems established by these schemes in the Indonesian context. The analysis was carried out as a desk study, based on the publicly available documentation of the schemes as well as key literature (see: Empirical materials). Furthermore, it assess the schemes ability to satisfy the FCAG framework scored by: fulfilled ( 1 point), partly fulfilled ( 0.5 point $)$, not fulfilled ( 0 point), and not applicable (-). The schemes were graded by their scores as to which best conforms to the FCAG criterion. However, the better schemes are not always most suitable for small and medium forest growers.

To capture a broader view regarding the schemes' suitability for small and medium forest growers, during January and February 2015, an online questionnaire was sent to relevant stakeholders including logging companies (23 respondents), wood-processing industries (23 respondents), wood-processing associations ( 7 respondents), auditors (22 respondents), environmental organizations (18 respondents), academics (11 respondents), and staff from the MoEF (4 respondents). The respondents were asked to share their opinion and experiences about existing schemes, to what extent they complement or compete with each other, and the impacts on these firms.

\section{Results}

The main findings highlighting the characteristics of the four certification and verification schemes against the FCAG requirements are presented. Detail assessment results and the weight of each scheme for each FCAG requirement are presented in Appendix.

\footnotetext{
${ }^{1}$ Besides FCAG, there are other frameworks for assessing certification schemes representing the view of specific interests (Purbawiyatna and Simula 2008). That is, the International Council of Forest and Paper Associations (forest industry), the Performance Standards of International Finance Corporation (financing institutions), public procurement policies of Denmark and the United Kingdom (government), and the Keurhout Protocols for validation of certification systems (timber importers).
} 


\subsection{Compliance with international frameworks}

The FSC fulfilled criterion compliance with international rules, namely International Standard Organization (ISO) Guide 62 or 65 and the International Social and Environmental Labelling (ISEAL) Alliance Code of Good Practice, while the IFCC, LEI, and SVLK as national level bodies cannot be an IAF or ISEAL member. However, the IFCC requires its certification members to comply with ISO/IEC 17011:2004 (IFCC ST 1002 2013). The IFCC also cooperates with the National Accreditation Committee (KAN), which represents Indonesia in the IAF. IFCC's standards are based on international frameworks including International Timber and Trade Organization (ITTO), ISO Guide, ILO, and PEFC standards (IFCC ST 1000 2013). Hence, the IFCC is considered partly compliant with international frameworks. The LEI carries out accreditation processes for certifying bodies (CBs) providing onsite certification systems, training institutions, and personnel for CBs. The CB is a legal entity competent in providing certification services and is recognized and accredited by national and international accreditation bodies (LEI 9901). The LEI accreditation manual refers to the Guideline No.3 of Indonesia's National Standardization Body (BSN), which refers to ISO documents. The SVLK, on the other hand, is a national government system assessing sustainable forest management and timber-legality verification. The Assessor and Verifier Independent Body (LP\&VI) is a legal company accredited by KAN (MoF 2012), which represents Indonesia in IAF, to assess the performance of sustainable production forest management. Regulations to assess the performance of sustainable

\subsection{Compatibility with globally applicable principles}

All schemes fulfilled Criterion 2 by mentioning all sub-criteria in their principles, criteria, and indicators. FSC principles have the same wording and thus comply with this criterion (Principle 1 to 10, FSC-STD-IDN-01-01). The IFCC, LEI, and SVLK are developed in accordance with all national and international rules and regulations. The IFCC fulfilled all FCAG Criterion 2 requirements, but used different wording. It covers production, ecological, and social aspects that are widely agreed as core principles in sustainable forest management (IFCC ST 1001 2013). The LEI has three different standards for different FMUs and tries to comply with SVLK, which is a government mandatory ruling. The LEI standards of natural, plantation, and community-based forests fulfilled all the FCAG Criterion 2 requirements. According to LEI 5000 (standardized to PHPL), LEI standards were developed in accordance with the International Timber and Trade Organization (ITTO) Criteria \& Indicator, ISO Standard 14000 series, and FSC Principles \& Criteria. LEI's standards were also developed with full accordance to the relevant Indonesian laws and regulations for forest management. The SVLK also has different standards for different FMUs and forest industries. The LEI and SVLK do not use "indigenous people," but "traditional or local communities." Instead of "critical natural habitats," the FSC uses "high-conservation-value forest," while the IFCC, LEI, and SVLK mention protected areas and endangered/rare/endemic species. The FSC regulates against conversion of the high-conservation value forest, while the IFCC, LEI, and SVLK still allow conversion where legally authorized.

\subsection{Meaningful and equitable participation}

In the standard-setting process, all schemes were established by multi-stakeholder participation. The FSC has three chambers, namely environment, social, and economic, and they should represent either North or South sub- 
chambers. Members can participate in FSC processes such as the development of standards, election of the Board of Directors, and voting on decisions that lead to the future of the organization. The FSC General Assembly is FSC's highest decision-making body, and meets every three years. The IFCC, on the other hand, has two caucuses (business and community) to accommodate different stakeholder requirements. The IFCC develops its standards in an open, multi-stakeholder and consensus based process (IFCC Statute 2013). The IFCC has a General Meetings of membership (GMM) as the paramount authority of the Association. LEI has four chambers (business, indigenous group and community, NGO, and eminent person), and as regulated by LEI Statutes, at least two-thirds of its members or $50 \%$ of members from each chamber must be present for the LEI congress to be legitimate. The SVLK does not have a chamber or caucus, but involve public consultations in their certification process. However, the SVLK was established by involving several stakeholders from government, industry, academic and research organizations, and NGOs, including the LEI as a facilitator. Currently, it is managed by the government via the SubDirectory of the TLAS. It allows independent observers to monitor the implementation of SVLK in Indonesia. Meaningful and equitable participation only occurs in public consultation and coordination of relevant stakeholders in the assessment phase. In decision making process, the FSC prefers voting power rather than a consensus, while the IFCC and LEI strive for consensus in their general assembly, and the SVLK does not use this method in their decision-making process.

\subsection{Avoidance of unnecessary obstacles to trade}

The FSC schemes follow the ISEAL Code as the basis to avoid unnecessary obstacles to trade, while the IFCC follows ISO/IEC guide 59, PEFC documentation, and ISEAL Code of Good Practice for Setting Social and Environmental Standards in the standard-setting process. The LEI is not a member of ISEAL, but LEI standards comply with their criterion. The SVLK, on the other hand, is derived from the FLEGT-VPA. Accordingly, all of the schemes fulfilled this criterion.

\subsection{Based on objective and measurable performance standards}

All standards of the FSC, IFCC, LEI, and SVLK are performance-based including chain of custody. They are quantifiable with indicators, verifications, and guidance on interpretation. All standards of the FSC, IFCC, LEI, and SVLK are based on international principles and criteria of sustainable forest management, such as the ITTO Criteria \& Indicator of Sustainable Management of Natural Tropical Forest and ISO 14000. In use of international operating systems, the FSC has a standard for local adaptation and endorses the national standard through the standard development group (SDG). For the national standard, the CBs must use interim standards before a national standard by the National Initiatives of the FSC is developed. Currently, adaptation of the local national standard is the task of the SDG. The PEFC also has a procedure for endorsement by a national body, while the IFCC is a PEFC official endorsed body. IFCC standards are performance-based with criteria for all types of forest management and chain of custody at the FMU level. The standards are written in quantifiable terms, with definitions of each criterion (IFCC ST 1001 2013). The FSC and PEFC require consistency in their national endorsed standards. However, these criteria are not applicable to LEI and SVLK as national bodies. 


\subsection{Certification decisions without conflicts of interest}

All schemes comply with this criterion by requiring decisions free from conflict of interest. The FSC fulfills all requirements of Criterion 6 by developing its standards according to relevant ISO rules. Certifications are conducted by accredited CBs, and the certification decision requires neutrality and expert judgment. The PEFC also separates standard settings, certification, and accreditation process into different organizations resolves potential conflicts of interest arising from accumulation of power in conformity assessment. The IFCC is not involved in the certification of the accreditation process, which done by the third parties. The IFCC certification scheme sets up requirements for the structure, procedures, and personnel of the CBs to ensure impartiality and competence. Similar, the LEI has developed different guidelines for each participator in the scheme including CBs, expert panels, and field assessors. The LEI guidelines for CBs (LEI 99-01,-04.-07), requires they not have relationships that may cause conflict of interest. In the LEI Guideline for Field assessors, the LEI also require they have no relationships with the management unit being assessed. This document shows that LEI requires its certification decision to be free from potential conflicts of interest. The SVLK requires freedom from conflict of interest by including this in its social

indicators. Reliable mechanisms for conflict resolution are sufficiently regulated by the government (MoEF Reg 14 2014).

\subsection{Transparency in decision making and public reporting}

All schemes require its CBs to publish reports on certification decisions and forest management evaluation. FSC, IFCC, and SVLK provide corrective action request in their surveillance results while the LEI does not require this. The FSC requires its CBs to prepare a forest certification public summary report for each forest management enterprise or group entity to which certificates are issued in accordance to requirements specified in standard. An update of the public summary report on forest management evaluation, including results of the surveillance audit and the Corrective Action Requests (CAR), are publicly available on the FSC database website or those of its CBs (FSC-STD-20-007b). The FSC are the only scheme who use CAR and publish information about its accreditation decisions. The IFCC and SVLK do not provide this because accreditation is done by a third party, while the LEI does not provide reports on the accreditation process on its website. All schemes require its CBs to publish reports on their own or the scheme's website. However, the FSC is the scheme that complies with requirements of Criterion 7 by publishing reports on its own or CB websites. The LEI and SVLK only comply with some requirements, such as public reports of forest management evaluation, but not on the surveillance or the accreditation process. For IFCC, as a new scheme in Indonesia, there is still no certification process. This results show that there is still a lack of transparency in the LEI and SVLK for providing publicly available reports on their certification and legalityverification processes.

\subsection{Reliable and independent assessment}

The FSC, IFCC and LEI declare themselves as independent, not for profit, transparent, participative/voluntarybased, and non-governmental organizations established to support environmentally appropriate, socially beneficial, and economically viable management of the world's forests (FSC 2014b, LEI 99, IFCC ST 1001). All schemes are 
independent with compliance to the international rules, including ISO Guides in developing their standards. Only the FSC and LEI accredit their CBs and both of them plan field visits. The IFCC and SVLK do not run accreditation procedures. All schemes require field visits and surveillance on certified FMUs in the pre-assessment or assessment stages. All schemes involve public consultation in their assessment process. All schemes have appropriate procedures to include stakeholders' comments in the certification process, but not in accreditation process for the IFCC, the LEI, and the SVLK. The FSC, IFCC, and LEI have their own standards about CoC, but SVLK does not regulate this. All schemes have a procedures and guidance on logo usage. The FSC regulates CoC certificates to exclude unacceptable sources, while IFCC uses the term "controversial sources." The LEI excludes illegal timber in the CoC standards, while SVLK does not have a regulation about CoC. However, it requires the exclusion of timber from illegal sources and conversion forests not legally authorized by the government. All schemes regulate complaints and appeals processes, and all are accessible to any party. However, only the FSC makes this information publicly available and free of charge (except for accreditation), while the IFCC, LEI, and SVLK provide correspondence and there is no information about the fee.

\subsection{Deliver continual improvement in forest management}

Only the FSC has a procedure for compliance of non-conformities, while the IFCC, LEI, and SVLK will not award certificates under the condition of non-compliance. The FSC requires surveillance at least annually for certification and accreditation and evaluates whether the breach is a major or minor non-conformity, which leads either to a CAR or suspension or withdrawal of the certificate. The CB cannot issue a certificate if there is any major nonconformity. However, there is a procedure and time limit to comply with CAR and non-conformity both in the accreditation and certification process (FSC-STD-20-007). The IFCC and SVLK also require surveillance at least annually for certification. IFCC Certificates are not issued if there are outstanding non-compliances. However, major and minor non-conformities must be corrected and CAR verified by the $\mathrm{CB}$ before granting certification and recertification. The period for completion of the CAR for major non-conformities identified in surveillance audits and their verification by the $\mathrm{CB}$ does not exceed three months. CAR for minor non-conformities are verified no later than the next audit (IFCC ST 1002 2013). The CBs of LEI, on the other hand, only issue certificate under the conditions of non-compliance in LEI. Certification decisions are classified into two categories, pass or fail, and in turn rated as Gold, Silver, Bronze, Copper, and Zinc. The certificate is awarded only to management units who receive Bronze, Silver, and Gold ratings (99-24.-34,-44). Surveillance visits are conducted by CBs at least twice within a five-year period for Gold ratings, 3 times for Silver ratings, and four times for Bronze ratings (99026,-36,46). Unlike other schemes, there is no V-legal certificate awarded if there are outstanding non-compliance issues in SVLK scheme. The PHPL certificate is issued to the auditee with intermediate or good results. When it has a poor result, but complies with wood-legality verification, a V-legal certificate is issued. The auditee has opportunity to correct their performance and re-apply for assessment. Surveillance visits are conducted once a year. There is no deadlines for compliance, if the auditee fails the surveillance, the certificate is suspended or revoked (MoEF Reg 14/2014). 


\subsection{Accessible and cost-effective for all parties}

All schemes have fulfilled this criterion by developing standards for different types and sizes of forests. The FSC has small or low-intensity managed forest (SLIMF) certification for small-forest holders who need cost-effective certification (FSC 2014b). The CBs classify the FMUs included in the scope of the evaluation as sets of like FMUs for the purpose of samplings, within each forest type, size, and the applicable national standard (FSC-STD-20-007). The PEFC has group certification (IFCC ST 1000 2013); the LEI has specific standards for plantation, nature, NTFP, and CBFM (LEI 5000-3); the SVLK has specific standards for plantation, nature, large/small industry and group. Especially for the SVLK, the government set new mechanisms through Regulation 95 to support small holders and communities by group certification, paying the first cost of certification and surveillance, and providing Supplier Conformity Declarations (DKP). This will make the SVLK more accessible and cost-effective to those who require this certification.

\subsection{Voluntary group participation}

The FSC Criteria (FSC-STD-30-005), LEI (LEI 5000-3), and SVLK (MoEF Reg 13 and 14 2014) develop their own standards of group certification. The IFCC do not have a specific standard, but the PEFC have already regulated group certification. All schemes require written agreements for membership of the group as part of the application. The members of the group must adhere to the standards of the scheme and the rules of the group. In case of a breach by the group, all schemes provide mechanism/procedures for the withdrawal/suspension, punishment/penalty, and even exclusion of the member.

\section{Discussion and conclusion}

Assessment against the FCAG framework shows that the FSC scheme fulfills almost 100\% of FCAG requirements. Consistent with Walter's (2006) findings, for a large number of issues examined, the FSC documentation delivered evidence of conformance with the FCAG framework, and this underlines the high credibility of the FSC scheme (Hinrichs and Prasetyo 2007). Due to the similarities in the standards, the IFCC and LEI have almost the same scores as second and third. This result contradicts Maryudi (2009) who concluded that for most of the FCAG criteria, LEI matched FSC and on some points, such as detail of its standards, even exceeded the FSC. Criteria concerning compliance to the international rules benefited the FSC, while the IFCC was assisted by the endorsement from the PEFC. The LEI and SVLK/PHPL met the criteria on standards and standard-setting process due to their local adaptability, detailed indicators, as well as verification and guidelines for reporting. All schemes that supported stakeholder involvement met the criteria for conformity assessment, certification, and accreditation. The SVLK/PHPL had the lowest scores because, as a government mandatory system, it could not fulfill some criteria in the FCAG frameworks, such as transparency and public reporting.

Specifically, we note that these schemes are different in six ways. First, internationality of the standard. As an international scheme, almost all requirements in FCAG match with FSC principles, criteria, and standards, and even share the same wording. Most of the non-compliances of the IFCC, the LEI, and the SVLK/PHPL, however, are the 
result of not-applicable requirements. For example, the FCAG frameworks require compliance to ISEAL or IAF, and since the IFCC, LEI, and the SVLK/PHPL tend to accommodate national circumstances, they cannot fulfill this criterion (Maryudi 2009). Criteria for compliance to international rules benefits the international scheme, the FSC, and the IFCC is assisted by the endorsement of the PEFC.

Second, compatibility with national needs. All standards are performance-based, accessible, and cost-effective in all scheme types by developing standards eligible for different types and sizes of forests. There are considerable differences between the FSC and the PEFC due to the approaches used-specifically, more international control for FSC versus more national autonomy for PEFC (Walter 2006). As a response to high demands for national adaptation, the FSC is now implementing the FSC-Indonesia national standard. The PEFC standard is considered more flexible, allowing a national endorsed scheme (IFCC) to accommodate national circumstances in standardsetting and certification. As oldest forest certification scheme in Indonesia, LEI has continuously been improved to achieve pre-conditions towards a sustainable forest management practices. The SVLK/PHPL is a mandatory system based on government regulation and national rules. Therefore, as a national voluntary scheme, the IFCC and the LEI try to adjust its compliance standards to the SVLK/PHPL.

Third, advocating small-scale forestry. FSC standards tend to focus more on natural forests, community forestry, and small holders (similar: Kruedener 2000; Auer 2012; Ota 2006) while the IFCC focuses on plantation forests (Overdevest 2010). This supported by Rametsteiner and Simula (2003) who found that the FSC advocates nature forestry based on, but not restricted to, non-introduced, indigenous species, while the PEFC allows planting of nonindigenous species on a larger scale. However, both prohibit wood sources from natural forests, while the LEI and the SVLK/PHPL accommodate this. The FSC also monitors comprehensive assessment across the supply-chain unlike the SVLK/PHPL. The SVLK/PHPL permits raw materials from non-forest area with legal origin documentation (Surat Keterangan Asal Usul), an earlier rule on Indonesian timber legality. To support the small enterprises and community forestry, all schemes provide group certification as voluntary participation. The FSC has group and SLIMF certification, the IFCC has group certification, the LEI has community forestry certification, and the SVLK/PHPL has group, community forestry, and small industry certification.

Fourth, clarity of timber source. The FSC regulates $\mathrm{CoC}$ certificates to exclude timber from unacceptable sources, while the IFCC uses the term "controversial sources." LEI-CoC standards clearly disallow illegal timber consumption while the SVLK/PHPL excludes timber from illegal sources and conversion forests not legally authorized by the government. On special provision, the FSC regulates against converting high-conservation-value forests, while the IFCC, the LEI, and the SVLK/PHPL allow conversion under certain circumstances if legally authorized.

Fifth, membership and public participation in standard development process. Each scheme has its own policy to include or exclude certain parties in their organizations and involve them in the process of standard development. The FSC has three chambers (environment, social, and economic), the LEI has four chambers (business, indigenous, and community, NGOs, and eminent persons), and the IFCC has two caucuses (Business and Community) to accommodate different stakeholder participation. The SVLK/PHPL does not have a chamber or caucus, but still involves public consultation in the certification process. All schemes develop their standards through multi- 
stakeholder processes and provide for equitable participation for different stakeholders in their standard-setting, certification/accreditation, and governance processes. To ensure decisions free from conflict of interest, the FSC opts for voting than consensus by stakeholders, while the LEI applies a consensus mechanism in their general assembly decision-making. Significant differences in the decision-making procedures between the FSC and the LEI prevail, which might lead to inconsistent certification decisions even in cases where similar field assessment results are reported (Hinrichs and Prasetyo 2007). Stakeholder involvement is intended by the PEFC, but decision-makers at the national level (IFCC) do not ensure a balance of interest and can be dominated by representatives of one stakeholder group (Walter 2006). In contrast to both, voting and consensus mechanisms are not used in decisionmaking processes in the SVLK/PHPL scheme.

Sixth, disputes on non-compliance performance of FMU. For continual improvement in forest management, only the FSC has procedures for compliance of non-conformities, while the IFCC, the LEI, and the SVLK/PHPL will not award certificates under the condition of non-compliance. The FSC emphasizes the improvisation and performance enhancement of FMUs when the assessment standard on one indicator differs between surveillances. The SVLK/PHPL does not implement gradual assessment. There are differences in the timing of surveillance visits, but all schemes have mechanisms for surveillance that support continual improvement in forest management.

Beyond these differences, we found competition among the schemes' proponents across the market. On some occasions (for example the Anti Forest-Mafia Coalition 2014) the WWF and its collaborators criticized the SVLK, including its legality definitions and inappropriate certification, and accused it of being designed to certify poorly performing companies. Apparently, their allegation strengthens the stereotype that schemes supported by government and industry lack transparency and public reporting (Nussbaum and Simula 2005; Overdevest 2010; Meridian et al. 2014). On the contrary, the Secretary General of the Ministry of Forestry claimed that the SVLK has higher standards than other schemes and companies do not require FSC certification (Sindonews 2013). Meanwhile, the PEFC through the IFFC claimed its scheme is better because it adapts to local needs and is based on forest companies' awareness of sustainable forest management practices, rather than merely meet market requirements (Citizen Daily 2013).

Competition among forest certification schemes is normal and widely observed in Sweden (Gulbrandsen 2005), Canada, the United States, Germany (Cashore et al. 2005), Russia (Malets 2015) and Indonesia (Nurrochmat et al. 2014). The aim of competition is not merely legitimacy and trust in the marketplace (Cashore et al. 2004; McDermott 2012) exists because of different norms and concepts of SFM in each scheme (Maryudi 2006). The proliferation of certification programs is the main driver of competition. Our respondents acknowledge that certification does not support their business directly. It provides brand image (22-26\%), supports environmental and social activities (21-26\%), and satisfies business relationships (14-16\%). Intense and unfavorable competition among the schemes could generate distrust by both timber-processing industries and timber-product buyers. As the weakest player, small-scale forest holders may build their own standard against established schemes and market coalitions (Keskitalo et al. 2009). If forest certification is driven for the interest of scheme holders, FMUs will only improve their management systems when they want to be certified, and CBs will consolidate their position with the 
FMUs and the government (Cadman, 2011). In addition, Kanowski et al. (2000) found that proliferation of schemes may cause confusion on the market and consumer apathy for certified products and this distracts preferences of environmentally concerned consumers from wood products.

Our survey proves that ideal scheme for improving forest governance and enhancing business practice is not automatically chosen by firms. As many as $60 \%$ of respondents acknowledge that the FSC is a necessary scheme for Indonesia, followed by the SVLK (13\%), the LEI (12\%), and the PEFC (9\%). However, respondents from logging companies and the wood-processing industry prefer to be certified under the SVLK (48-57\%), followed by the FSC (43-48\%), the PEFC (13-43\%), and the LEI (9-29\%). This preference is strongly influenced by mandatory nature of the SVLK, government subsidy, and market acceptance. In summary, good certification schemes are not gaining market leadership. To overcome this gap, respondents suggest mutual recognition among the schemes with common standards. Some analysts (for example, Atyi and Simula 2002; Fischer 2005) also recommend this. However, mutual recognition may double the cost of assessment, and lead to unsuccessful cooperation as it did with the FSC and the LEI joint certification program in late 2000s (Innes and Hickey 2005).

It should be noted that each scheme cannot work alone to achieve a successful forest certification implementation in the field. The scheme holders need to work together or at least to support government programs in realizing longterm stable forestland tenure and small-scale forestry businesses (He et al. 2015). Reciprocally, scheme standards should be synchronized and adaptable to local forestry practices and respect domestic laws and regulations (Wiersum et al. 2013). In the case of Indonesia, success in timber-legality verification could result in forest certification (Maryudi 2015), especially for firms that want to reach a broader market or improve brand image, although this may not increase the quality of forest management (Nordén et al. 2015).

\section{References}

Alemagi, D., Hajjar, R., David, S., \& Kozak, R.A. (2012) Benefits and barriers to certification of community-based forest operations in Cameroon: An exploratory assessment. Small-scale Forestry, 11(4), 417-433.

Anti Forest-Mafia Coalition. (2014). SVLK flawed: An independent evaluation of Indonesia's timber legality certification system. http://eyesontheforest.or.id/attach/Anti\%20Forest\%20Mafia\%20Coalition\%20\%2818Mar14\%29\%20SVL K\%20Flawed\%20FINAL.pdf. Accessed 26 June 2015.

Auer, M. R. (2012). Group forest certification for smallholders in Vietnam: an early test and future prospects. Human Ecology, 40(1), 5-14.

Bartley, T. (2003). Certifying forests and factories: States, social movements, and the rise of private regulation in the apparel and forest products fields. Politics \& Society, 31(3), 433-464.

Bernstein, S., \& Cashore, B. (2004). Non-state global governance: is forest certification a legitimate alternative to a global forest convention. Hard choices, soft law: Voluntary standards in global trade, environment and social governance, 33-63.

Cadman, T. (2011). Quality and Legitimacy of global governance: case lessons from forestry. Palgrave Macmillan 
Ltd.

Cashore, B., \& Auld, G., \& Newsom, D. (2004). Governing through markets: Forest Certification and the Emergence of Non-state Authority. Yale University Press. New Haven, CT. USA.

Cashore, B., \& Van Kooten, G. C., Vertinsky, I., Auld, G., \& Affolderbach, J. (2005). Private or self-regulation? A comparative study of forest certification choices in Canada, the United States and Germany. Forest Policy and Economics, 7(1), 53-69.

Citizen Daily (2013, June $10^{\text {th }}$ ). Ketika dua raksasa sertifikasi hutan rebutan pasar. http://citizendaily.net/ketikadua-raksasa-sertifikasi-hutan-rebutan-pasar/. Accessed 10 June 2015.

Crow, S., \& Danks, C. (2010). Why certify? Motivations, outcomes and the importance of facilitating organizations in certification of community-based forestry initiatives. Small-Scale Forestry, 9(2), 195-211.

Fischer, C., Aguilar, F., Jawahar, P., \& Sedjo, R. (2005). Forest Certification: Toward Common Standards? Discussion Paper 05-10. April 2005. Resources for the Future, Washington, D.C.

FSC. (2008). Facts and figures on FSC growth and markets. Forest Stewardship Council. http://www.ipef.br/pccf/artigos/FSC_Fatos_e_Mercado_Fev_2008_Ingles.pdf. Accessed 8 May 2015.

FSC. (2014a). Global FSC certificates: type and distribution. Forest Stewardship Council. https://ic.fsc.org/preview.facts-and-figures-november-2014.a-3810.pdf. Accessed 18 June 2015.

FSC. (2014b). History and National Standards. Forest Stewardship Council. http://ic.fsc.org/. Accessed 4 April 2015 https://ic.fsc.org/preview.facts-and-figures-november-2014.a-3810.pdf. Accessed 18 June 2015.

Gulbrandsen, L. H. (2003). The evolving forest regime and domestic actors: strategic or normative adaptation?. Environmental Politics, 12(2), 95-114.

Gulbrandsen, L. H. (2005). Sustainable forestry in Sweden: the effect of competition among private certification schemes. The Journal of Environment \& Development, 14(3), 338-355.

Harada, K., \& Wiyono. (2014). Certification of a community-based forest enterprise for improving institutional management and household income: a case from Southeast Sulawesi, Indonesia. Small-scale forestry, 13(1), 47-64.

He, M., Wu, Z., Li, W., \& Zeng, Y. (2015). Forest certification in collectively owned forest areas and sustainable forest management: A case of cooperative-based forest certification in China. Small-scale Forestry, 1-10.

Hinrichs, A., \& Prasetyo, A. (2006). Forest certification credibility assessment in Indonesia: Applying the Forest Certification Assessment Guide at the national level. World Bank/WWF Alliance for Forest Conservation and Sustainable Use, Washington, DC, USA. http://www.lei.or.id/files/download_Guide a9c8b6.pdf . Accessed 12 June 2015.

Innes, J. L., \& Hickey, G. M. (2005). Management and Wood Products.Forestry and Environmental Change: Socioeconomic and Political Dimensions: Report No. 5 of the IUFRO Task Force on Environmental Change, 11, 143 .

Kanowski, P., Sinclair, D., \& Freeman, B. (2000). Establishing Comparability and Equivalence amongst Forest Management Certification Schemes: Critical elements for the assessment of schemes. Department of Agriculture, Fisheries \& Forestry-Australia, Canberra. 
Keskitalo, E. C. H., Sandstrom, C., Tysiachnjouk, M., \& Johansson, J. (2009). Local consequences of applying international norms: differences in the application of forest certification in northern Sweden, northern Finland, and northwest Russia. Ecology and Society, 14(2).1.

Klingberg, T. (2003). Certification of forestry: a small-scale forester perspective. Small-scale Forest Economics, Management and Policy, 2(3), 409-421.

Kruedner, B. V. (2000). FSC forest certification: enhancing social forestry developments? Forests, Trees, and People Newsletter, (43), 12-18.

LEI. (2013, June). LEI's certified forests. http://www.lei.or.id. Accessed 7 May 2015.

Lidestav, G., \& Lejon, S. B. (2011). Forest certification as an instrument for improved forest management within small-scale forestry. Small-scale forestry, 10(4), 401-418.

Malets, O. (2015). When Transnational Standards Hit the Ground: Domestic Regulations, Compliance Assessment and Forest Certification in Russia. Journal of Environmental Policy \& Planning, 17(3), 332-359.

Maryudi, A. (2006). Sertifikasi Hutan: Instrumen Baru Dalam Kebijakan Kehutanan. Rimba Kalimantan, 11(1), 2735.

Maryudi, A. (2009). Forest certification for community-based forest management in Indonesia: does LEI provide a credible option?. Hayama-mati(Kanagawa-ken): Institute for Global Environmental Strategies, Forest Conservation, Livelihoods, and Rights Project.

Maryudi, A. (2015). The political economy of forest land-use, the timber sector, and forest certification. In: Romero, C., Putz, F. E., Sills, E. O., Guariguata, M. R., \& Maryudi, A. (Eds.) The context of natural forest management and FSC certification In Indonesia (No. CIFOR Occasional Paper no. 126). Center for International Forestry Research (CIFOR), Bogor, Indonesia.

McDermott, C. L. (2012). Trust, legitimacy and power in forest certification: A case study of the FSC in British Columbia. Geoforum, 43(3), 634-644.

McDermott, C. L., Irland, L. C., \& Pacheco, P. (2015). Forest certification and legality initiatives in the Brazilian Amazon: Lessons for effective and equitable forest governance. Forest Policy and Economics, 50, 134142.

Meidinger, E. (2003). Forest certification as a global civil society regulatory institution. Social and political dimensions of forest certification, 265-289.

Meridian, A., Minangsari, M., Hasyim, Z., Valentinus, A., Sari, N. A., Sutiah, U., \& Kosar, M. (2014). SVLK in the eyes of the monitor: Independent monitoring and a review of the implementation of the timber legality verification system, 2011-2013. Indonesia Independent Forestry Monitoring Network. Bogor, Indonesia.

Muhtaman, D. R., \& Prasetyo, A. P. (2006). Forest certification in Indonesia. In Confronting Sustainability: Forest Certification in Developing and Transitioning Countries Edited by B.Cashore, F.Gale, E. Meidinger, and D.Newsom. Yale School of Forestry and Environmental Studies.

Nordén, A., Coria, J., \& Villalobos, L. (2015). Impact Evaluation of forest certification in Sweden. http://www.webmeets.com/files/papers/eaere/2015/379/Forest\%20Certfication_2015_06_10_version_EA ERE2015.pdf. Accessed 14 June 2015. 
Nurrochmat, D. R., Dharmawan, A. H., Obidzinski, K., Dermawan, A., \& Erbaugh, J. T. (2014). Contesting national and international forest regimes: Case of timber legality certification for community forests in Central Java, Indonesia. Forest Policy and Economics. doi:10.1016/j.forpol.2014.09.008 .

Nussbaum, R., \& Simula, M. (2005). The Forest Certification Handbook. Earthscan. London.

Obidzinski, K., Dermawan, A., Andrianto, A., Komarudin, H., \& Hernawan, D. (2014). The timber legality verification system and the voluntary partnership agreement (VPA) in Indonesia: Challenges for the small-scale forestry sector. Forest Policy and Economics, 48, 24-32.

Ota, I. (2006). Experiences of a forest owners' cooperative in using FSC forest certification as an environmental strategy. Small-scale Forest Economics, Management and Policy, 5(1), 111-125.

Overdevest, C. (2010). Comparing forest certification schemes: the case of ratcheting standards in the forest sector. Socio-Economic Review, 8(1) 47-76.

Overdevest, C., \& Zeitlin, J. (2014). Assembling an experimentalist regime: Transnational governance interactions in the forest sector. Regulation \& governance, 8(1), 22-48.

PEFC. (2014, November). PEFC Global Statistics: SFM \& CoC Certification. http://www.pefc.org/about-pefc/whowe-are/facts-a-figures. Accessed 14 April 2015.

Purbawiyatna, A., Simula, M. (2008). Comparability and acceptance of forest certification systems. Main Report. ITTO. In: Karmann, M., \& Smith, A. (ed) FSC reflected in scientific and professional literature: Literature study on the outcome and impacts of FSC certification. FSC International Center.

Rametsteiner, E., \& Simula, M. (2003). Forest certification-an instrument to promote sustainable forest management?. Journal of Environmental Management, 67, 87-98.

SILK. (2014). List of Certificate Holders. silk.dephut.go.id/index.php/info/iuiphhk. Accessed 14 April 2015.

Sindonews. (2013, July $\left.20^{\text {th }}\right)$. Kayu Indonesia tak perlu sertifikat FSC. http://ekbis.sindonews.com/read/773114/34/kayu-indonesia-tak-perlu-sertifikat-fsc-1376966700. Accessed 4 March 2015.

Suntana, A. S., Asycarya, D., Iskandarsyah, Y., \& Iswari, P. (eds.) (2000). Sustainable Production Forest Management (SPFM) Certification System. Bogor: The Indonesian Ecolabeling Institute.

UNECE, \& FAO. (2013). Forest Products Annual Market Review, 2012-2013. New York and Geneva, United Nations, Geneva, Timber and Forest Study Paper, 33.

Walter, M. (2006, updated 2008). Analysis of the FSC and PEFC Systems for forest Management certification using the Forest Certification Assessment Guide. http://assets.panda.org/downloads/2008 11_17 final_fcag_assessment_pdf. Accessed 17 April 2015.

Walter, M. (2011). Analysis of the PEFC system for forest management certification using the forest certification assessment guide

(FCAG). http://awsassets.panda.org/downloads/2011_03_20_mwalter_fcag_analysis_pefc.pdf. Accessed 12 June 2015.

Wibowo, A., Sahide, M. A. K., \& Giessen, L. (2015). From voluntary private to mandatory state governance in Indonesian forest certification: Reclaiming authority and legitimacy by bureaucracies. Unpublished 
paper. University of Goettingen, Germany.

Wiersum, K. F., Humphries, S., \& Van Bommel, S. (2013). Certification of community forestry enterprises: experiences with incorporating community forestry in a global system for forest governance. Small-scale Forestry, 12(1), 15-31.

Wiersum, K. F., \& Elands, B. H. (2013). Opinions on legality principles considered in the FLEGT/VPA policy in Ghana and Indonesia. Forest Policy and Economics, 32, 14-22.

WWF, \& WB. (2006, July). Forest Certification Assessment Guide (FCAG): A Framework for Assessing Credible Forest Certification Systems/Schemes. WWF/World Bank Global Forest Alliance. http://siteresources.worldbank.org/EXTFORESTS/Resources/FCAG_WB_English.pdf. Accessed 11 May 2015.

WWF. (2015). WWF Forest Certification Assessment Tool (CAT). http://wwf.panda.org/what_we_do/how_we_work/businesses/transforming_markets/news/?246871/WWF -Forest-Certification-Assessment-Tool-CAT. Accessed 11 May 2015

\section{Empirical materials}

FSC Documents

1. FCS-STD-01-001 V4-0 $\rightarrow$ Principle \& Criteria (2002)

2. FSC National Initiatives Manual replaced by FSC-PRO-60-001 V1-0 Procedure for the operation of the FSC Network (2012)

3. FSC-STD-20-001 V3-0 $\rightarrow$ General requirements for CB (2009)

4. $\quad$ FSC-STD-60-002 $\rightarrow$ Structure and content of National FSC Standards (2012)

5. FSC-STD-60-006 $\rightarrow$ Process requirements for development and maintenance of national standards (2009)

6. FSC-STD-20-002 V3-0 $\rightarrow$ Structure, content and Local adaptation of generic FSC(2009)

7. FSC-STD-20-006 V3-0 $\rightarrow$ Stakeholder consultation for forest evaluation (2009)

8. FSC-STD-20-007 V3-0 $\rightarrow$ Forest Management Evaluations (2009)

9. FSC-STD-20-011 V2-0 $\rightarrow$ CoC Evaluation (2007)

10. FSC-STD-30-010 $\rightarrow$ FSC standard for forest management enterprises (2006)

11. FSC-STD-40-004 V2-1 $\rightarrow \mathrm{CoC}(2011)$

12. FSC-POL-40-002 $\rightarrow$ Group CoC (2004)

13. FSC-STD-40-003 V2-1 $\rightarrow$ Multisite CoC (2007)

14. FSC-STD-40-005 V2-1 $\rightarrow$ FSC-certified controlled wood (2007)

15. FSC-STD-40-006 V1-0 $\rightarrow$ CoC project (2006)

16. FSC-STD-40-201 on product labelling requirements (2004)

17. FSC-STD-IDN-01-01-2013 $\rightarrow$ Indonesia natural plantation and SLIMF standard (2013)

18. FSC-STD-01-003 V1-0 $\rightarrow$ SLIMF Eligibility Criteria (2004)

19. ASI-PRO-20-101 $\rightarrow$ Accreditation procedure (2010)

\section{PEFC/IFCC Documents}

1. IFCC Statute (2013)

2. IFCC ST $1000 \rightarrow$ IFCC Certification Scheme (2013)

3. IFCC ST $1001 \rightarrow$ SFM requirements (2013)

4. IFCC ST $1003 \rightarrow$ IFCC Logo usage rules (2013)

5. IFCC ST $1002 \rightarrow$ Requirements for bodies providing audit and certification of sustainable management (2013)

6. IFCC ST 2002-1 $\rightarrow$ CoC of forest based products (2013)

7. IFCC PD $1001 \rightarrow$ Standard setting procedures (2012)

8. IFCC PD $1002 \rightarrow$ procedures for investigation and resolution of complaints and appeals (2013)

9. IFCC PD $1003 \rightarrow$ Issuance of the IFCC and PEFC logo licenses in Indonesia (2013)

10. IFCC PD $1004 \rightarrow$ Notification of Certification Bodies (2013) 
11. PEFC IFCC ST 2003 $\rightarrow$ Requirements for Certification bodies operating certification against the PEFC International CoC Standard (2012)

12. PEFC IFCC ST $2002 \rightarrow$ CoC of forest based products requirements (2013)

13. PEFC IFCC ST $2001 \rightarrow$ PEFC Logo usage rules-requirements (2008)

14. PEFC ST $1002 \rightarrow$ Group forest (2010)

\section{LEI Documents}

1. $\quad$ LEI 5000 Sustainable production forest management (1999)

2. LEI 5000-1 Sustainable natural forest management (1999)

3. LEI 5000-2 Sustainable plantation forest management (2014)

4. LEI 5000-3 Community based-forest management (2002)

5. LEI 5005 Terms and Definition related to forest certification (2001)

6. LEI Guideline 55 Resolution guideline to appeal against the certification decision (1999)

7. LEI Guideline 99 SPFM Certification System (1999)

8. LEI Guideline 99-01, 99-04, 99-07 General Requirements for CB (Various years)

9. LEI Guideline 99-02, 99-05, 99-08 General Requirements for CBFM Field Assessor (Various years)

10. LEI Guideline 99-03, 99-06, 99-09 General Requirements for Expert Panel (Various years)

11. LEI 99-21, 99-31, 99-41 Field Assessment Guideline (Various years)

12. LEI 99-22, 99-32, 99-42 Report Writing Field Assessment Guideline (Various years)

13. LEI 99-23, 99-33, 99-43 Guideline for the Screening Process (Various years)

14. LEI 99-24, 99-34, 99-44 Decision-making Guideline on Certification (Various years)

15. LEI 99-25, 99-35, 99-45Guideline on the drawing up recommendations for Certification (Various years)

16. LEI 99-26, 99-36, 99-46 Guideline for Surveillance Implementation and Certificate (Various years)

17. LEI Guideline 88 CoC Certification System (Various years)

18. LEI Guideline 88-01 General Requirements for CoC CB (Various years)

19. LEI 88-21 Field Assessor Guideline (Various years)

20. LEI 88-22 Guideline for Report Writing Field Assessment (Various years)

21. LEI 88-23 Guideline for Screening Process on CoC(Various years)

22. LEI 88-24 Guideline for certification decision process of expert panel (Year not given)

23. LEI 88-25 Guideline for Drawing up Recommendations (Year not given)

24. LEI 88-26 Guideline for Surveillance (Year not given)

\section{SVLK Documents}

1. MoF. Regulation (Permenhut) No. P38/Menhut-II/2009 jo P68/Menhut-II/2011 jo P45/Menhut-II/2012 jo P42/Menhut-II/2013 jo P43/Menhut-II/2014 jo P95/Menhut-II/2012. Standards and guidelines on implementation of performance assessment of sustainable management of production forest and TLAS (SVLK).

2. MoF. Regulation of the Director General No. P.6/VI-Set/2009, P.02/VI-BPPH/2010, P.8/VI-BPPHH/2011, P.8/VI-BPPHH/2012, P.5/VI-BPPHH/2014, P.14/VI-BPPHH/2014, P.1/VI-BPPHH/2015. Standards and guidelines on implementation of performance assessment of sustainable management of production forest and timber legality assurance system (SVLK).

3. MoEF. Regulation of the Minister of Environment and Forestry, P.96/Menhut-II/2014. Revision of P.13/Menhut-II/2013 concerning the cost standard on PHPL and SVLK assessment. 
Table
Click here to download Table: Appendix.docx

1 2

3

4

5

6

7

9

10

11

12

13

14

15

16

17

18

19

20

21

22

23

24

25

26

27

28

29

30

31

32

33

34

35

36

37

38

39

40

41

42

43

44

45

46

47

48

49

50

51

52

53

54

55

56

57

58

59

60

61

62

63

64

65

(1) 
Appendix 1: The comparison results of contested schemes using FCAG framework

\begin{tabular}{lcccc}
\hline Criterion and Requirements & \multirow{2}{*}{ FSC } & PEFC/ \\
IFCC & LEI & $\begin{array}{c}\text { SVLK/ } \\
\text { PHPL }\end{array}$
\end{tabular}

I. Compliance with International Norms and Standards

Criterion 1 - Compliance with international frameworks for certification, accreditation, and standard setting accreditation organization.

b. Monitoring and surveillance carried out by the organizations cover $\quad 1 \quad-\quad 1$ the activities of accreditation in the field of forest management.

c. All CBs are accredited for activities carried out for the forest $\quad \begin{array}{llll}1 & 1 & 1 & 1\end{array}$ management certification scheme under assessment.

d. Accreditation requires compliance with ISO Guide 62, 65, or 66. $\quad 1 \quad 1 \quad 1 \quad 0,5$

e. Standard-setting bodies are affiliated with the ISEAL Alliance. $\quad \begin{array}{llllll} & 1 & - & -\end{array}$

II. Standards and the Standards-Setting Process

$\begin{array}{lllll}\text { Subtotal I } & 5 & 2,5 & 3 & 1,5\end{array}$

Criterion 2 - Compatible with globally applicable principles that balance economic, ecological and equity dimensions of forest management and meet Global Forest Alliance Requirements.

Compliance with all relevant laws.

Respect for tenure and use rights.

Respect for indigenous peoples' rights.

Respect for community relations.

Respect for workers' rights.

Delivery of multiple benefits from the forest.

Assessment and mitigation of environmental impacts.

Maintenance of critical forest areas and related natural critical habitats.

$\begin{array}{llll}1 & 1 & 1 & 1 \\ 1 & 1 & 1 & 1 \\ 1 & 1 & 1 & 1 \\ 1 & 1 & 1 & 1 \\ 1 & 1 & 1 & 1 \\ 1 & 1 & 1 & 1 \\ 1 & 1 & 1 & 1 \\ 1 & 1 & 1 & 1\end{array}$

The schemes/systems explicitly require that forest operations maintain

critical forest areas and other critical natural habitats affected by the operation.

Specific provisions for plantations.

Implementation of management plan.

Effective monitoring and assessment.

$\begin{array}{ccccc} & 1 & 0,5 & 0,5 & 0,5 \\ & 1 & 1 & 1 & 1 \\ \text { Subtotal 2 } & 1 & 1 & 1 & 1 \\ & 11 & 10,5 & 10,5 & 10,5\end{array}$

Criterion 3 - Meaningful and equitable participation of all major stakeholder groups in governance and standard setting

a. Relevant stakeholder groups have been officially invited to participate.

b. Relevant stakeholder groups participate meaningfully.

c. A procedure is in place to involve stakeholders in case of failure to achieve meaningful participation of relevant major stakeholder groups.

d. Written documents are available on what efforts have been taken to include stakeholders and how issues raised by stakeholders have been addressed.

e. The decision-making process is striving for consensus among relevant stakeholder groups.

f. Procedures are in place to achieve balanced decision making in the $\quad \begin{array}{lllll}1 & 1 & 1 & 0\end{array}$ absence of consensus.

$\begin{array}{ccccc}\text { Subtotal } 3 & 6 & 6 & 6 & 3,5 \\ & 1 & 1 & 1 & 1 \\ \text { Subtotal } 4 & 1 & 1 & 1 & 1\end{array}$

Criterion 5 - Based on objective and measurable performance standards that are adapted to local conditions

a. The standard contains explicit performance requirements, including $\quad \begin{array}{lllll}1 & 1 & 1\end{array}$ chain of custody, if relevant. 
b. The standard is written in quantifiable terms, with guidance on interpretation if flexibility is required.

c. International principles and criteria used as the basis for development of national standards include provisions for the operational level (FMU) in case of an internationally operating system.

d. Mechanisms and processes are in place to facilitate the harmonization/equivalence of national standards or national schemes within the international system.

e. Processes exist for consistency between national standards.

f. National standards are endorsed by the international system.

Subtotal 5

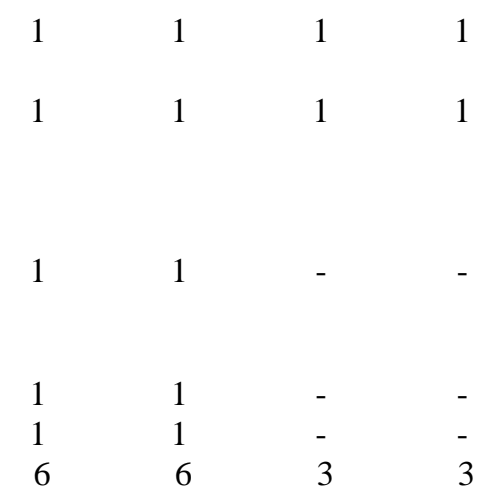

III. Conformity Assessment, Certification and Accreditation

Criterion 6 - Certification decisions free of conflicts of interest from parties with vested interests

$\begin{array}{lllll} & 1 & 1 & 1 & 1 \\ \text { Subtotal } 6 & 1 & 1 & 1 & 1\end{array}$

Criterion 7 - Transparency in decision making and public reporting

7.1 Public availability of scheme requirements

For standard-setting bodies the ISEAL Code of Good Practice for

Setting Social and Environmental Standards specifies the following publication requirements:

- Complaints resolution mechanism

- Annual work program, including a description of the standards under development, scope, objectives, and rationale

- Draft standards

- Written synopsis of comments received during public consultation and how these were addressed

- Standard-setting procedures

The certification scheme/system makes documents publicly available

7.2 Public availability of certification and accreditation reports.

a. Public reports on forest management evaluation and surveillance provide the rationale for the certification decision.

b. Public reports on forest management evaluation justify the certification decision by providing key findings with respect to compliance with the standard.

c. Public reports on forest management evaluation and surveillance include the CAR raised in regard to the performance of the operation being evaluated.

d. Public reports on accreditation provide the rationale for the accreditation decision.

e. Public reports on accreditation provide the CAR raised in regard to $\quad \begin{array}{lllll}1 & 0 & 0 & 0\end{array}$ the performance of the evaluated CB.

f. Public reports are readily available. $\quad \begin{array}{llll}1 & 0,5 & 1 & 1\end{array}$

$\begin{array}{lllll}\text { Subtotal } 7 & 8 & 5,5 & 5 & 6,5\end{array}$

Criterion 8 - Reliable and independent assessment of forest management performance and chain of custody

8.1 Independence of assessments

The Global Forest Alliance partners consider the independence of the assessment as the basis of any credible certification.

8.2 Field evaluation of forest management and CB performance.

a. Accreditation procedures for the initial evaluation and surveillance $\begin{array}{llllll}1 & 0 & 1 & 0\end{array}$ of CBs require field visits to certified-FMUs.

b. Accreditation requirements specify evaluation and surveillance $\quad 1 \quad 1 \quad 1 \quad 1$ intensity to be applied by CBs.

c. CBs require field visits to applicant FMUs before a certificate can $\quad \begin{array}{lllll}1 & 1 & 1 & 1\end{array}$ 
be issued.

8.3 Chain of custody requirements

a. The scheme has a standard for the control of chain of custody that covers production and trade from the forest of origin to the final product.

b. Standards and control mechanisms exist to prevent application of logos on uncertified timber.

c. Chain-of-custody certificate holders are required to exclude timber from illegal sources and from conversion of forests.

d. Procedures for claims comply with ISO Standards 14020 and 14021.

8.4 Stakeholder consultation in the certification and accreditation process.

a. Accreditation bodies undertake proactive and culturally appropriate external consultation as part of initial assessment and surveillance of CBs.

b. CBs undertake proactive and culturally appropriate external consultation as part of initial assessment and surveillance of certificate holders.

c. Appropriate procedures exist to incorporate stakeholder comments in the decision-making process for certification and accreditation.

8.5 Complaints and appeals mechanisms

Complaints and appeals mechanisms of accreditation, certification and standard-setting bodies are: a) accessible to any interested party; b) publicly available; and c) free of cost implications for the complainant.

Subtotal 8

Criterion 9 - Delivers continual improvement in forest management

a. The scheme sets deadlines for full compliance if certificates are issued under the condition of fulfillment of outstanding noncompliance.

b. Surveillance visits from CBs and accreditation bodies are carried out at least annually.

c. Clear deadlines exist for compliance, with CAR issued as a result of surveillance.

Subtotal $9 \quad 2,5 \quad 1,5 \quad 0,5 \quad 0,5$

Criterion 10 - Accessible to and cost-effective for all parties

a. Mechanisms exist that allow equity of access to all participants, regardless of the size, location, or forest type under operational management.

b. The above mechanisms provide access to forest certification at a cost that does not exclude small-forest owners, communities, and other groups that may have limited access.

Criterion 11 - Voluntary participation

Subtotal 10

a. In cases of group certification, a set of contractual arrangements exists between the owners or their designated intermediary and the entity that holds the group certificate for the requirements of certification.

b. A mechanism exists to ensure that each member of the group must meet the standard or exit the group

c. Enforcement mechanisms exist in case of breach of the group rules.

$\begin{array}{ccc}0,5 & 0,5 & 0,5 \\ 1 & 0 & 0 \\ 1,5 & 0,5 & 0,5 \\ 1 & & \end{array}$




\begin{tabular}{|c|c|c|c|c|}
\hline $\begin{array}{l}\text { d. All participating forest owners have signed a commitment to } \\
\text { adhere to the standards set by the scheme. }\end{array}$ & 1 & 0,5 & 1 & 1 \\
\hline Subtotal 11 & 4 & 2 & 4 & 4 \\
\hline Total 1 until 11 & 58,5 & 47 & 46 & 41 \\
\hline
\end{tabular}

Source : WWF \& World Bank (2006), adapted by Maryudi (2009)

Note: fulfilled (1 point), partly fulfilled (0.5 point), not fulfilled ( 0 point), and not applicable (-). 


\section{Formal and Scientific Education}

1998-2003: Bachelor in Forestry - Lambung Mangkurat University, Banjarmasin, Indonesia Thesis: 'Analysis of Hanna Victory \& Co's Rattan Carpet Marketing' (GPA: 3.18)

2006-2008: Master in Forest Sciences - Bogor Agricultural University, Bogor, Indonesia Thesis: 'Analysis of Furniture Industrial Clustering in Palangka Raya' (GPA: 3.52 )

2012-2015: PhD in Forest Policy - Georg-August University Goettingen, Germany Thesis: 'International forest policies in Indonesia: International influences, power changes and domestic responses in REDD+, One Map and forest certification politics'

\section{Permanent Position}

Lecturer in Forest Economics and Policy at Faculty of Agriculture, University of Palangka Raya, Indonesia (Since 2005).

\section{Scholarships/Grants}

$>$ Indonesia-German Scholarship Program (IGSP) PhD study (2012-2016)

$>$ Postgraduate Scholarship for Master study (2006-2008)

$>$ I-MHERE grant for training on econometrics techniques for forest management (August 2009)

$>$ I-MHERE grant for training on forest certification (September-October 2011)

$>$ Research grants for junior lecturer (2009 and 2010) 